SAND90-0301

Unlimited Release

Printed May 1990

Distributinn

Category UC-

702

\title{
1989 ENVIRONMENTAL MONITORING REPORT SANDIA NATIONAL LABORATORIES, ALBUQUERQUE, NEW MEXICO
}

S. Hwang, G. Chavez, J, Phelan, A. Parsons

G. Yeager, D. Dionne, B. Schwartz, T. Wolff

J. Fish, C. Gray, D. Thompson

ES\&H Directorate 3200

Sandia National Laboratories

Albuquerque, New Mexico 87185

\begin{abstract}
This 1989 report contains monftoring data from routine radiological and nonradiological environmental survelllance activities. Summaries of significant environmental compliance programs in progress such as National Environmental Policy Act documentation, environmental permits, environmental restoration, and varlous waste management programs for Sandia National Laboratorles in Albuquerque (SNL, Albuquerque) are included. The maximum offsite dose impact was calculated to be $8.8 \times 10^{-4} \mathrm{mrem}$. The total Albuquerque population recelved a collective dose of 0.097 person-rem during 1989 from SNL, Albuquerque, operations. As in the previous year, SNL, Albuquerque, operations in 1989 had no adverse impact on the general public or on the environment. This report is prepared for the U.S. Department of Energy in compliance with DOE Order 5400.1.
\end{abstract}




\section{ACKNOWLEDGMENTS}

This report was complled by the staff of the Environment, Safety and Health Directorate (3200) of Sandia National Laboratories, Albuquerque. R. Gomez and $R$. Hamilton of the Radioactive and Mixed Waste Division (3222) assisted in the environmental sample collection. C. Massey, $A$. Solow, and $T$. Roybal of Division 3222, R. Helgese, L. Marlman, and K. Molley of Division 3221, and $M$. Irwin of Division 3223 assisted in providing information for waste management activities and compliance assessments. K. Gruelich of the Industrial Hygiene Division (3211) assisted with the radiological sample analyses. W. Booker of IT Corporation provided the Quality Assurance results for non-radiological analyses. J. Fish of Division 3222 assisted in the editorial review, and $J$. Meloche of Division 7537 provided photography for use in this report. G. J. Smith, Manager of Environmental Programs Department (3220), performed the technical review of this report. 


\section{CONTENTS}

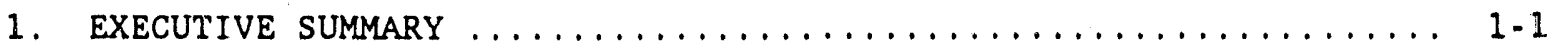

1.1 Assessment of Enviroumenta], Compliance Activities ........ 1.1

1.2 Assessment of Radiological Impact for the Public.......... 1-3

1.3 Overview of 1989 Monitoring Results................. 1.3

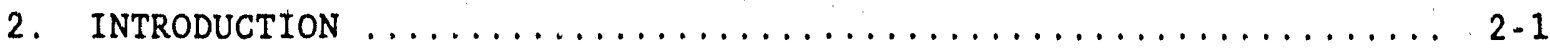

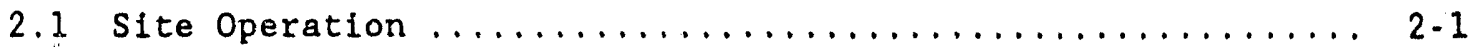

2.2 Location and Population ........................... 2.1

2.3 Climate and Meteorology ....................... 2-3

2.4 Geology .................................... 2-3

2.5 Hydrology and Blology $\ldots \ldots \ldots \ldots \ldots \ldots \ldots \ldots \ldots \ldots, 2-3$

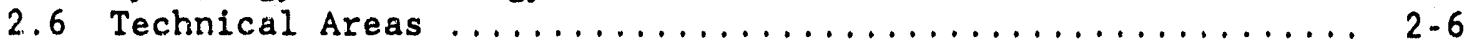

3. SUMMARY OF SIGNIFICANT ENVIRONMENTAL ACTIVITIES $\ldots \ldots \ldots \ldots \ldots \ldots, 3-1$

3.1 NEPA Compliance and Documentations $\ldots \ldots \ldots \ldots \ldots \ldots \ldots \ldots, 1$

3.2 Environmental Permits ........................ 3.3

3.3 Environmental Monitoring Programs ................. 3.4

3.4 Summary of 1989 Release Reporting .................. 3-6

4. OTHER ENVIRONMENTAL COMPLIANCE PROGRAMS $\ldots \ldots \ldots \ldots \ldots \ldots \ldots \ldots, 4-1$

4.1 Environmental Restoration (ER) Program .............. 4-1

4.2 Under Ground Storage Tanks (USTs) Management

and Spill Prevention Control Plan ..................4.3

4.2.1 Underground Storage Tanks (USTs) ............. 4-3

4.2.2 Spill Prevention Control Plan (SPCC) ........... 4-3

4.3 Waste Management Programs $\ldots \ldots \ldots \ldots \ldots \ldots \ldots \ldots \ldots \ldots \ldots, 4.3$

4.3.1 Mixed Waste Compliance Programs ............... 4-3

4.3 .2 Radioactive Waste ........................ 4.4

4.3.3 Special Case Waste ...................... 4-4

4.3.4 Hazardous Waste and the Resource Conservation and Recovery Act (RCRA) ................... 4.4

4.3.5 Waste Minimization and Pollution Prevention Awareness ............................ 4-5

4.3.6 Polychlorinated Biphenyl (PCB) Waste .......... 4.9

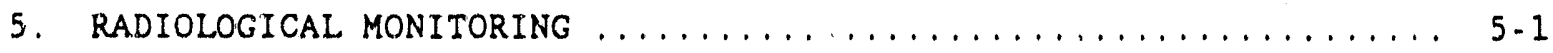

5.1 Radioactive Effluent Monitoring ................... 5.1

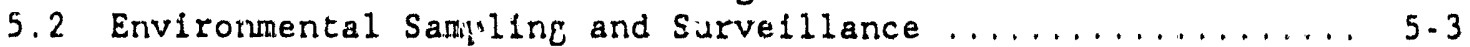

5.3 Potential Dose Assessment for the Public .............. 5.12 


\section{CONTENTS}

(Continued)

\section{Page}

6. NONRADIOLOGICAL MONITORING $\ldots \ldots \ldots \ldots \ldots \ldots \ldots \ldots \ldots \ldots \ldots \ldots \ldots \ldots$

6.1 Waste Water, Storm Watex, and Surface

Discharge Programs ........................... 6-1

6.1 .1 Waste Water Programs ...................... 6.1

6.1 .2 Storm Water Programs ..................... 6-8

6.1 .3 Surface Discharge Programs ................... 6.10

6.2 Alr Quality Monitoring ...................... 6-10

6.2 .1 Air Quality ............................ 6-10

6.2.2 Airborne Emissions and Permits ............... 6.11

6.2 .3 Emission Inventory $\ldots \ldots \ldots \ldots \ldots \ldots \ldots \ldots \ldots \ldots . \ldots \ldots 6.14$

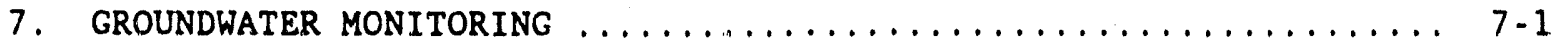

7.1 Review of the Groundwat Monitoring Program .......... 7-1

7.2 Background Setting $\ldots \ldots \ldots \ldots \ldots \ldots \ldots \ldots \ldots \ldots \ldots \ldots \ldots \ldots \ldots \ldots, 1$

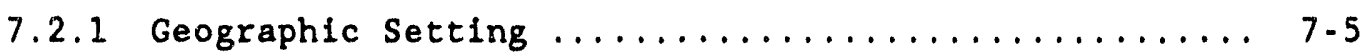

7.2 .2 Geology .............................. $7-5$

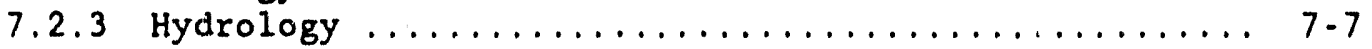

7.31989 Groundwater Monitoring Activities ............. $7-9$

7.3.1 Water-Level Measurements .................. 7.9

7.3 .2 Groundwater Sampling ..................... 7.9

7.3.3 Sampling Procedures and Methods .............. 7-12

7.3.4 Water Quality Background Monitoring Data ......... 7-14

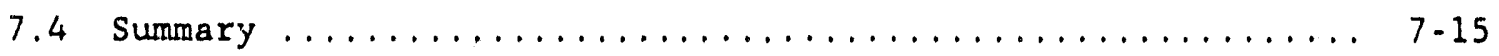

8. QUALITY ASSURANCE PROGRAMS $\ldots \ldots \ldots \ldots \ldots \ldots \ldots \ldots \ldots \ldots \ldots \ldots$

8.1 Quality Assurance (QA) for Environmental Programs ........ 8-1

8.2 Quality Assurance (QA) of Environmental Sampling

and Analysis ............................... $8-2$

8.3 Quality Assurance (QA) of Data Management ............ 8-5

8.4 Quality Assurance (QA) of Outside Analytical

Laboratories ................................ 8-5

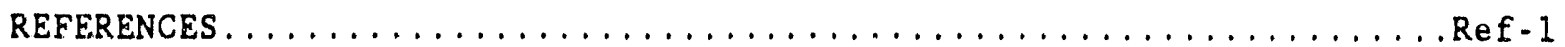

APPENDIX A METEOROLOGICAL DATA ...................... A-I

APPENDIX B SANDIA NATIONAL LABORATORIES ALBUQUERQUE, ENVIRONMENTAL RESTORATION PROGRAM SITES $\ldots \ldots \ldots \ldots \ldots \ldots$ B-1 


\title{
CONTENTS \\ (Concluded)
}

\begin{abstract}
Page
APPENDIX $C$ SAMPLE COLLEC $C I O N$ AND ANALYSIS $\ldots \ldots \ldots \ldots \ldots \ldots \ldots \ldots \ldots$. APPENDIX $\mathrm{D}$ MINIMUM DETEC'TION IIIMITS AND ANALYTICAL METHODS $\ldots \ldots \ldots \ldots$ D-1

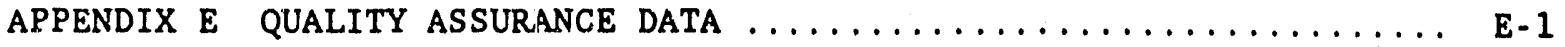

APPENDIX $F$ ENVIRONMENTAL MONITORING DATA $\ldots \ldots \ldots \ldots \ldots \ldots \ldots \ldots \ldots, F-1$

APPENDIX $G$ ENVIRONMENTAL REGULATIONS AND STANDARDS $\ldots \ldots \ldots \ldots \ldots \ldots \ldots G-1$ APPENDIX H OTHER ENVIRONMENTAL COMPLIANCE RECORDS $\ldots \ldots \ldots \ldots \ldots \ldots \ldots, \mathrm{H}-1$

APPENDIX I LIST OF NEPA DOCUMENTATION ...................... I 1

APPENDIX J 1989 ENVIRONMENTAL COMPLIANCE ACTIVITIES AT KAUAI

TEST FACILITY........................... J-I
\end{abstract}




\section{FIGURES}

Figure

rage

2-1 Albuquerque Site Regional Setting .................. 2-2

2-2 Annual Surface Wind Speed and Direction,

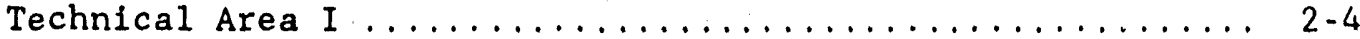

2-3 Mesa Vegetation .......................... 2-7

2-4 Manzano Foothills Vegetation .................... 2-7

2.5 SNL, Albuquerque, Technical Areas (I-V) and Remote

Areas .................................. 2-8

2-6 A Group of Deer at the Main Burn Site in Coyote

Test Field................................. 2-11

2.7 Coyote Wondering Near Solar Tower, Technical Area III...... 2-11

2-8 An Owl Sitting on a Telephone Pole Near Thunder Range...... 2-12

2.9 Deer at Coyote Canyon......................... 2-12

4-1 Task Map for Sandia National Laboratories, Albuquerque .... 4-2

5.1 Surmary of Atmospheric Release of ${ }^{41} \mathrm{Ar},{ }^{3} \mathrm{H},{ }^{85} \mathrm{Kr}$, and

133 Xe From Sandia-Albuquerque Facilities Since $1975 \ldots \ldots \ldots$ 5-2

5-2 Environmental Monitoring Locations in Technical

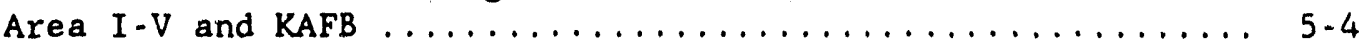

5-3 Community Monitoring Locations in the Albuquerque Area ..... 5-5

5-4 Offsite Receptor Locations of Potential Maximum

Dose Impacts................................ 5-16

6.1 Waste Water Discherge Sampling Locations.............. 6.7

7-1a Location of Chemical Waste Landfill (CWL), Technical

Area III ................................. 7-2

7-1b Monitor Well Locations at the Sandia Chemical Waste

Landfill (CWL) ............................ 7-3

7.2 Monitoring Well Locations at the Mixed Waste

7-3 The Location of SNL in the Albuquexque-Belen Basin ...... 7-6

7-4 Potentiometric Contours of the SNL, Albuquerque,

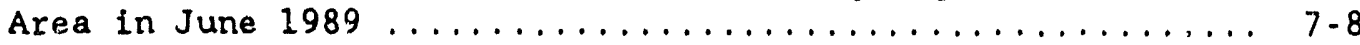

7.5 Location of the Monitor Wells and Kirtland Air Force

Base (KAFB) Production Wells in the SNL, Albuquerque, Area

(modified from SAIC, 1985) ....................... 7-10

J-1 Map of the Pacific Missile Range Facility and the

Adjacent Area................................ J 4 


\section{TABLES}

Table

Page

2-1 Summary Meteorological Data for the Albuquerque Area

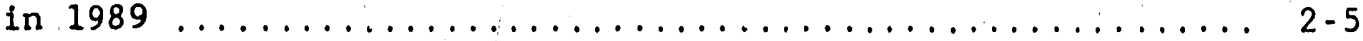

3-1 Summary of the Environmental Permits Issued or

in Process ............................... 3-5

3-2 Annual Summary of 1989 Reportable Quality (RQ)

Release Reporting........................... 3-7

4-1 SNL, Albuquerque, Hazardous Waste Transporters Used

in CY89 ................................ 4-6

4-2 SNL, Albuquerque, Waste Disposal Facilities Used

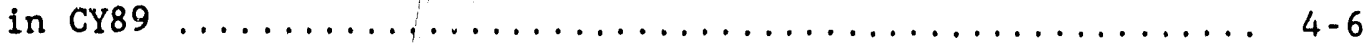

5-1 SNL, Albuquerque Enyironmental Monitoring Locations

and Sample Types for Radioactive Surveillance ............ 5-7

5-2 Mean Concentrations of $3_{\mathrm{H}}$ and $137 \mathrm{Cs}$ in Vegetation ........ $5-8$

5-3 Mean Concentrations of Uranium, $137 \mathrm{Cs}$, and $3 \mathrm{H}$ in

5.4 Mean Concentrations of Gross $\alpha$, Gross $\beta$, Uranium,

${ }^{137} \mathrm{Cs}$ and ${ }^{3} \mathrm{H}$ in Surface Water (Streams) ............ 5-10

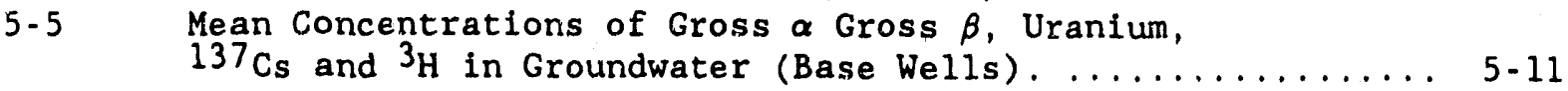

5-6 Summary of TLD Measurements ................... $5-11$

5-7 Summary of Airborne Radioactive Emissions............... 5-13

5-8 1989 Dose Calculations of the Seven Historic Receptors

for SNL, Albuquerque......................... 5-14

5-9 Radiation Doses to Public Receptors Surrounding SNL,

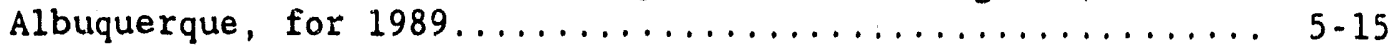

5-10 Summary of Offsite Dose Impacts in Comparison to NESHAP

Standards and the Nature Background Radiation.......... 5-17

6-1 Waste Water Discharge Permits, SNL, Albuquerque ......... $6-2$

6-2 SNL, Albuquerque, Wastewater Sample Locations ........... $6-3$

6-3 Summary of pH Excursions for Station WW005 During 1989 ... 6-5

6-4 Summary of Fluoxide Exceedances at MDL During $1989 \ldots \ldots \ldots .6 .6$

6-5 Sampling Parameters and Concentrations Limits Specified

by Surface Water Discharge Plan DP-530 ............. 6-8

6-6 Summary of Annual One-Day Composite Parameters,

SNL, Albuquerque, June $1989 \ldots \ldots \ldots \ldots \ldots \ldots \ldots \ldots . \ldots \ldots$ 6.9. . . . . .

6-7 1989 Water Level Masurements for Lagoons I and II,

Technical Area IV, SNL, Albuquerque ................66-11

6-8 1989 Maljor Cations, Anions, and TDS for Lagoons I and II,
Technical Area IV, SNL, Albuquerque ................. $6-12$

6.9 1989 Organic Compounds Detected for Lagoons I and II,

Technical Area IV, SNL, Albuquerque ................ 6-13 


\section{TABLES \\ (Continued)}

Table

Page

7-1 Water Level Elevations Measured for Chemical waste

Landfill (CWL) Wells ........................ 7-11

7-2 Water Level Elevations Measured for Mixed Waste

Landfill (MWL) Wells ....................... 7-12

7-3 Water Level Elevations Measured for Monitoring and

Production Wells ........................... 7.13

8-1 1989 Quality Assurance Results for Selected Radio-

chemical Analysis ......................... 8-3

8-2 Determination of Sample Val lability in Replicate

Samples for Selected Analysis in Vegetation, Soll,

and Surface Water ............................ 8-4

8-3 Summary of Relative Percent Difference Measurements

for Environmental Duplicate Sample Analyses Performed

During 1989 at ENSECO ........................ 8-8

8-4 Summary of Relative Percent Difference Measurements

for Environmental Duplicate Sample Analyses Performed

During 1989 at ENCOTEC ........................ 8-9

A-1 Long-Term Historical Data (1951 to 1980) for the

Albuquerque Area ............................ A-3

A-2 Normals, Means, and Extremes, Albuquerque, New Mexico

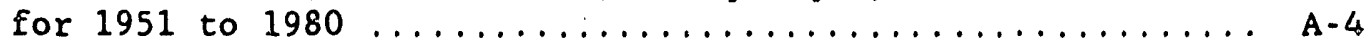

B-1 SNL, Albuquerque Environmental Restoration

Program Sites .............................. B-3

C-1 Sampling Frequencies and Types of Analysis for

Radioactive Effluent Monitoring Program ............... C-12

C-2 Recommended Analytical Methods, Sample Containers,

Preservation Techniques, and Holding Times ............ C-13

C-3 Summary of Characteristics for SNL, Albuquerque,

Waste Water Sampling Stations ................... C-17

C.4 Pollutant Concentration Limits, Waste Water Discharge

Permit 2069A, Sampling Station Wwoc1 ................ C-18

C-5 Pollutant Concentration Limits, Waste Water Discharge

Permit 2069C-2, Sampling Station WW003 ................ C-19

C-6 Pollutant Concentration Limits, Waste Water Discharge

Permit 2069D-2, Sampling Station WW004 ............... C-20

C-7 Pollutant Concentration Limits, Waste Water Discharge

Permit 2069G, Sampling Station ww007 ................ C-21

C-8 Pollutant Concentration Limits, Waste Water Discharge

Permit 2069F, Sampling Station WW006 ................ C.22

C-9 Sampling and Analytical Methodology, SNL, Albuquerque

Waste Water Monitoring Stations.................... C-23 


\section{TABLES \\ (Continued)}

Table

Page

D-1 Radiochemical Analysis Minimum Detection Limits (MDL) ...... D-3

D-2 Analytical Methods, Detection Limits, and QC Acceptance Criteria for Analysis of Waste Water Samples ........... D-4

E-1 List of Nonradioactive Environmental Samples Collected During CY89 ............................. E-3

E-2 List of Laboratories Used During CY89 .............. E-3

E-3 Summary of Analytical Results for Check Samples Submitted to Encotec During $1989 \ldots \ldots \ldots \ldots \ldots \ldots \ldots \ldots$ E 4 . . . . .

E-4 Summary of Analytical Results for Check Samples Submitted to Encotec During $1989 \ldots \ldots \ldots \ldots \ldots \ldots \ldots$ E-5

E-5 Contents of 18 Quality Elements .................. E-16

F-1 $\quad 1989$ Vegetation Sample Analysis ................... F-3

F-2 1989 Soil Sample Analysis ......................... $F-4$

F-3 $\quad 1989$ Water Sample Analysis - Surface Water . . . . . . . . . F-5

F-4 1989 Water Sample Analysis - Well Water .............. F-6

F-5 1989 Thermoluminescent Dosimeter (TLD) Summary Radiation

Exposure Data .............................. F-7

F-6 1989 Calculated Effluent Release Data.............. F-8

F-7a Background Concentrations of Groundwater Contamination

Indicator Parameters for $\mathrm{BW}-3 \ldots \ldots \ldots \ldots \ldots \ldots$ F-9

F-7b Background Concentrations of Groundwater Contamination

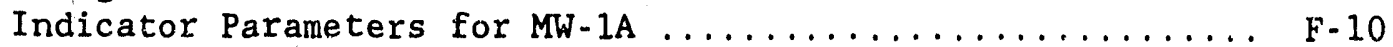

F-7c Background Concentrations of Groundwater Contamination

Indicator Parameters for MW-2A ................... F-11

F-7d Background Concentrations of Groundwater Contamination

Indicator Parameters for MW-3A .................. F-12

F-8a Background Concentrations of Groundwater Quality

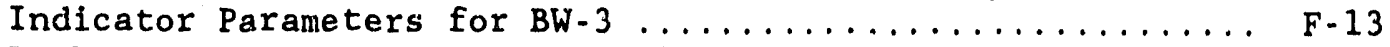

F-8b Background Concentrations of Groundwater Quality

F-8c Background Concentrations of Groundwater Quality

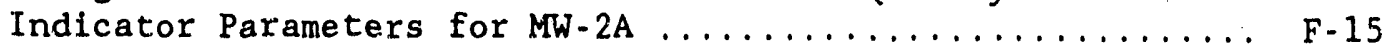

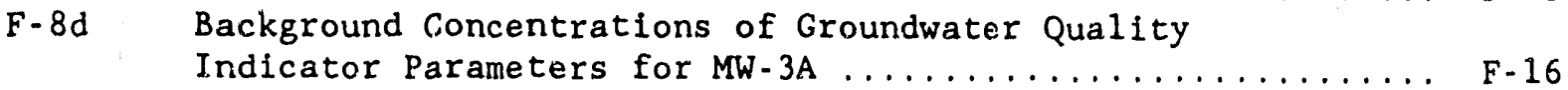

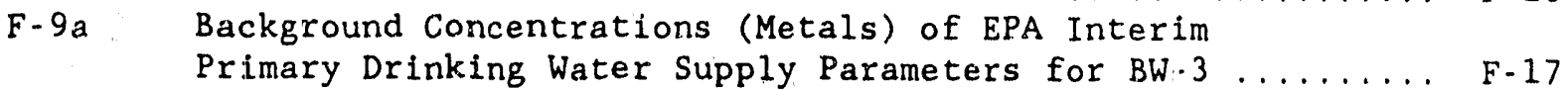

F-9b Background Concentrations (Metals) of EPA interim
Frimary Drinking Water Supply Parameters for MW-1A ....... F-18

\begin{tabular}{l|l} 
F-9c & Background Concentrations (Metals) of EPA Interim \\
& Primary Drinking Water Supply Parameters for $M W-2 A \ldots \ldots$
\end{tabular}

F-9d $\begin{aligned} & \text { Background Concentrations (Metals) of EPA Interim } \\ & \text { Primary Drinking Water Supply Parameters for MW-3A ....... F-20 }\end{aligned}$

F-10a Background Concentrations (Others) of EPA Interim
Primary Drinking Water Supply Parameters for BW-3 ....... F-21 


\section{TABLES \\ (Concluded)}

Table

Page

F-10b Background Concentrations (Others) of EPA Interim

Primary Drinking Water Supply Parameters for MW-1A ....... F-22

F-10c Background Concentrations (Others) of EPA Interim

Primary Drinking Water Supply Parameters for MW-2A ....... F-23

F-10d Background Concentrations (Others) of EPA Interim

Primary Drinking Water Supply Parameters for MW-3A ....... F-24

F-11 Summary of Gross Alpha and Uranium Isotope Alpha

Activities at the sNL Chemical Waste Landfill (CWL),

June 1989

F-25

F-12 Summary of Uranium Isotope Mass Distribution,

SNL Chemical Waste Landfi11 (CWL), June $1989 \ldots \ldots \ldots \ldots \ldots$ F-26

F-13 Summary of Four-Day Averages of Analytical Results for

Waste Water Sampling Station Ww001, Permit No. 2069A

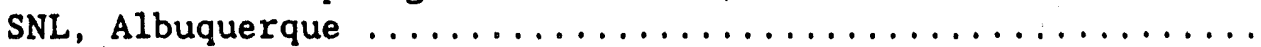

F-27

F-14 Summary of Four-Day Averages of Analytical Results for

Waste Water Sampling Station WW003, Permit No. 2069C-2

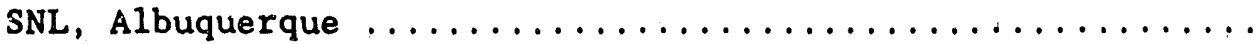

$\mathrm{F}-28$

F-15 Suminary of Four-Day Averages of Analytical Results for

Waste Water Sampling Station WW004, Permit No. 2069D-2

SNL, Albuquerque ...............................

F-29

F-16 Summary of Four-Day Averages of Analytical Results for

Waste Water Sampling Station WW005, Permit No. 2069E-2

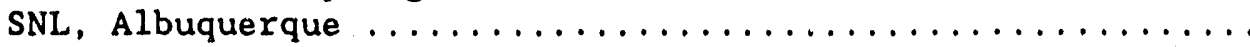

F -30

F-17 Summary of Four-Day Averages of Analytical Results for

Waste Water Sampling Station WW006, Permit No. 2069F

F-18 Summary of Four-Day Averages of Analytical Results for

Waste Water Sampling Station WW007, Permit No. 2069G

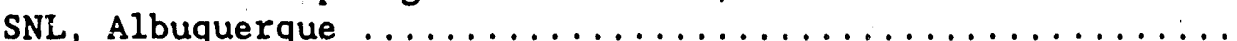

G-1 Radiation Standards for Protection of the Public in

the Vicinity of DOE Facilities for CY89 ............. G-3

G-2 Derived Concentration Guides (DCG) For Selected

Radionuclides ............................ G.4

G-3 Groundwater Monitoring Parameters Required by

40 CFR Part 265, Subpart F ..................... G-5

G-4 EPA Interim Primary Drinking Water Supply Parameters ...... G-6

H-1 SNL, Albuquerque, Underground Storage Tanks (USTs) Closed

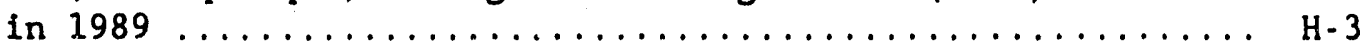

H-2 SNL, Albuquerque, USTs Registered as of $12 / 31 / 89 \ldots \ldots \ldots \ldots$ H-4

H-3 Septic Tank Registration, SNL, Albuquerque $\ldots \ldots \ldots \ldots \ldots \ldots$ H-6

H-4 Sandia Environmental Incident Form ................. H-9

I-1 List of NEPA Documentation $\ldots \ldots \ldots \ldots \ldots \ldots \ldots \ldots \ldots \ldots \ldots$

J-1 Summary of 1989 RQ Release Reporting.............. J-7 


\section{ABBREVIATIONS}

\section{System International Prefixes}

$\begin{array}{cccccc}\text { Exponent } & \text { Prefix } & \text { Symbol } & \text { Exponent } & \text { Prefix } & \text { Symbol } \\ 10^{6} & \text { mega } & M & 10-9 & \text { nano } & \mathrm{n} \\ 10^{3} & \text { kilo } & \mathrm{K} & 10-12 & \text { pico } & \mathrm{p} \\ 10^{-3} & \text { milli } & \mathrm{M} & 10-15 & \text { femto } & \mathrm{f} \\ 10^{-6} & \text { micro } & \mu & 10-18 & \text { atto } & \mathrm{a}\end{array}$

\section{Units}

$\begin{array}{llll}\mathrm{cm} & \text { centimeter } & \mathrm{kg} & \text { kilogram } \\ { }^{\circ} \mathrm{C} & \text { degree Celsius } & \mathrm{L} & \text { liter } \\ \mathrm{ft} & \text { feet } & \text { lps } & \text { liters per second } \\ \text { gpd } & \text { gallons per day } & \mathrm{m} & \text { meter } \\ \mathrm{gpm} & \text { gallons per min } & \mathrm{mi} & \text { mile } \\ \mathrm{g} & \text { gram } & \mathrm{min} & \text { minutes } \\ \mathrm{h} & \text { hour } & \mathrm{ml} & \text { milliliter } \\ \text { ha } & 10,000 \text { square meters } & \text { \& moisture weight percent of water } \\ \text { in } & \text { inch } & \mathrm{s} & \text { seconds } \\ \mathrm{J} & \text { Joule } & \mathrm{yr} & \text { year }\end{array}$

\section{Symbols}

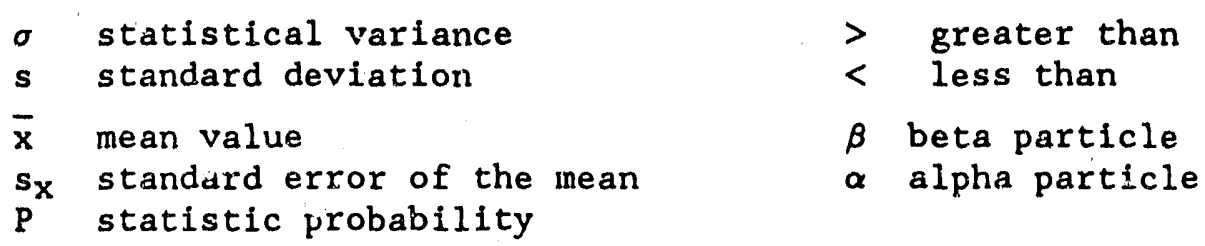

Nuclide Symbols for Frequently Referenced Nuclides and Components

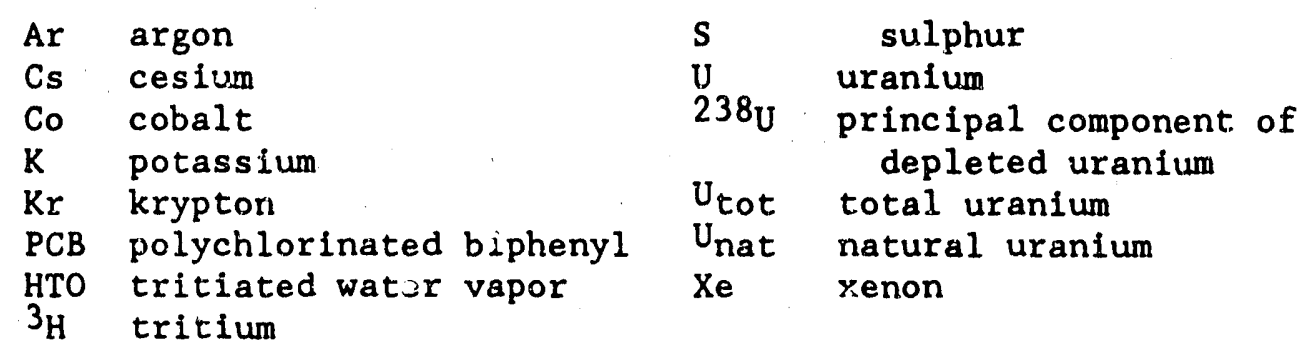

\section{Radioactivity measurements}
Ci curie (unit of radioactivity)
person-rem radiation dose to population
$\mathrm{mR}$
milliroentgen (unit of radiation exposure)
mrem millirem (unit of radiation dose)




\section{ABBREVIATIONS (Continued)}

\section{Water Quality Measurements and Abbreviations}

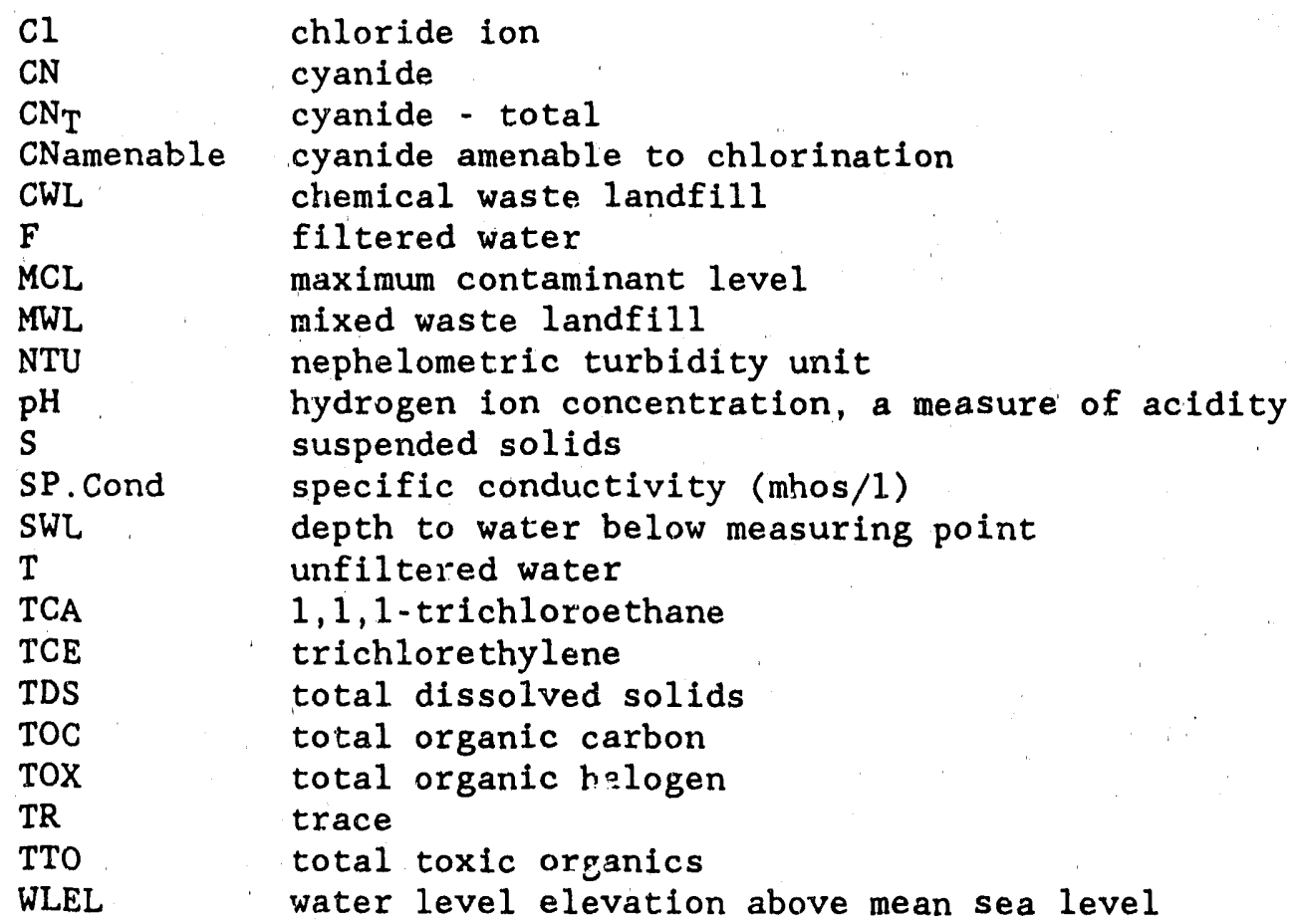

Acronyms

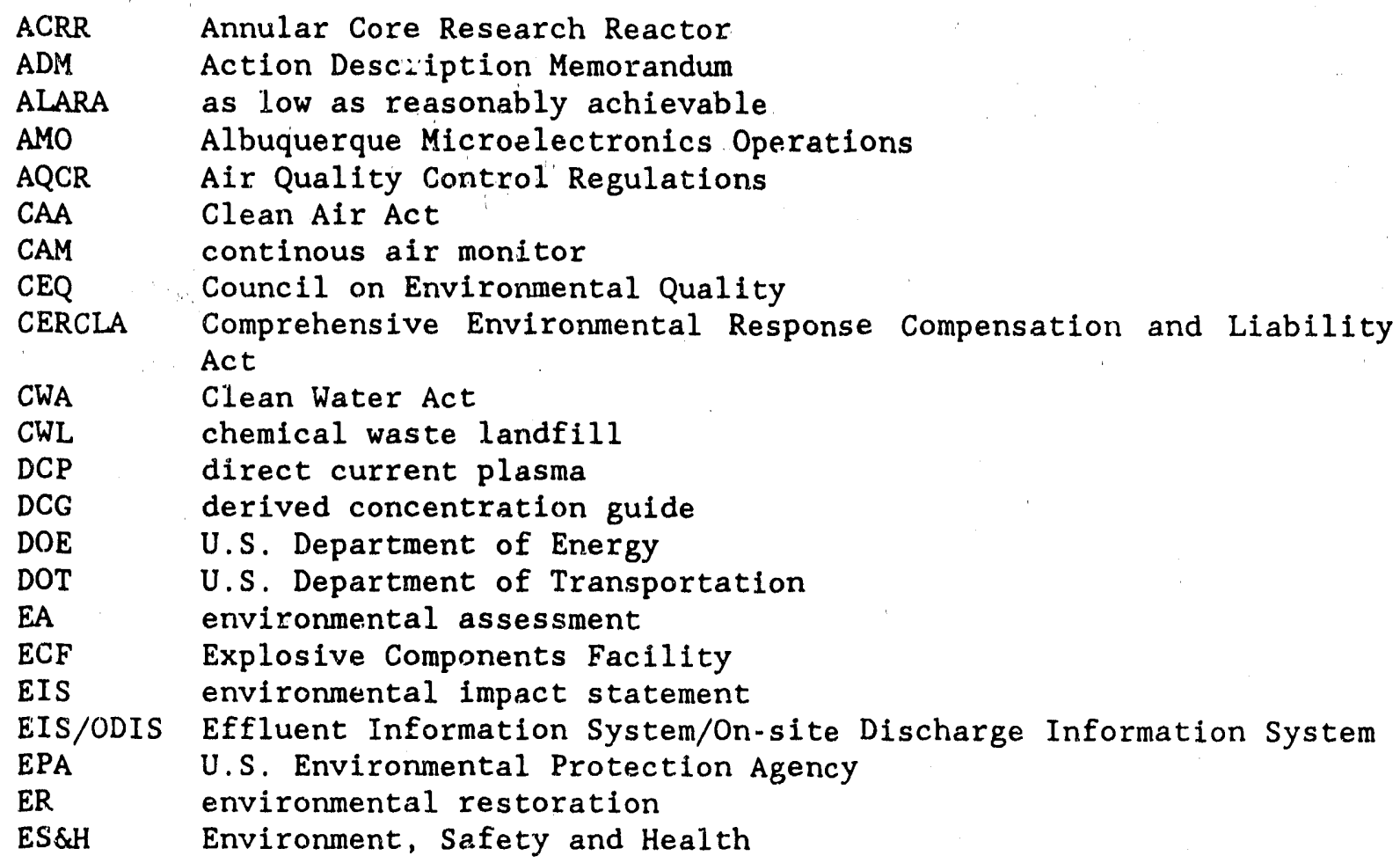




\section{ABBREVIATIONS (Continued)}

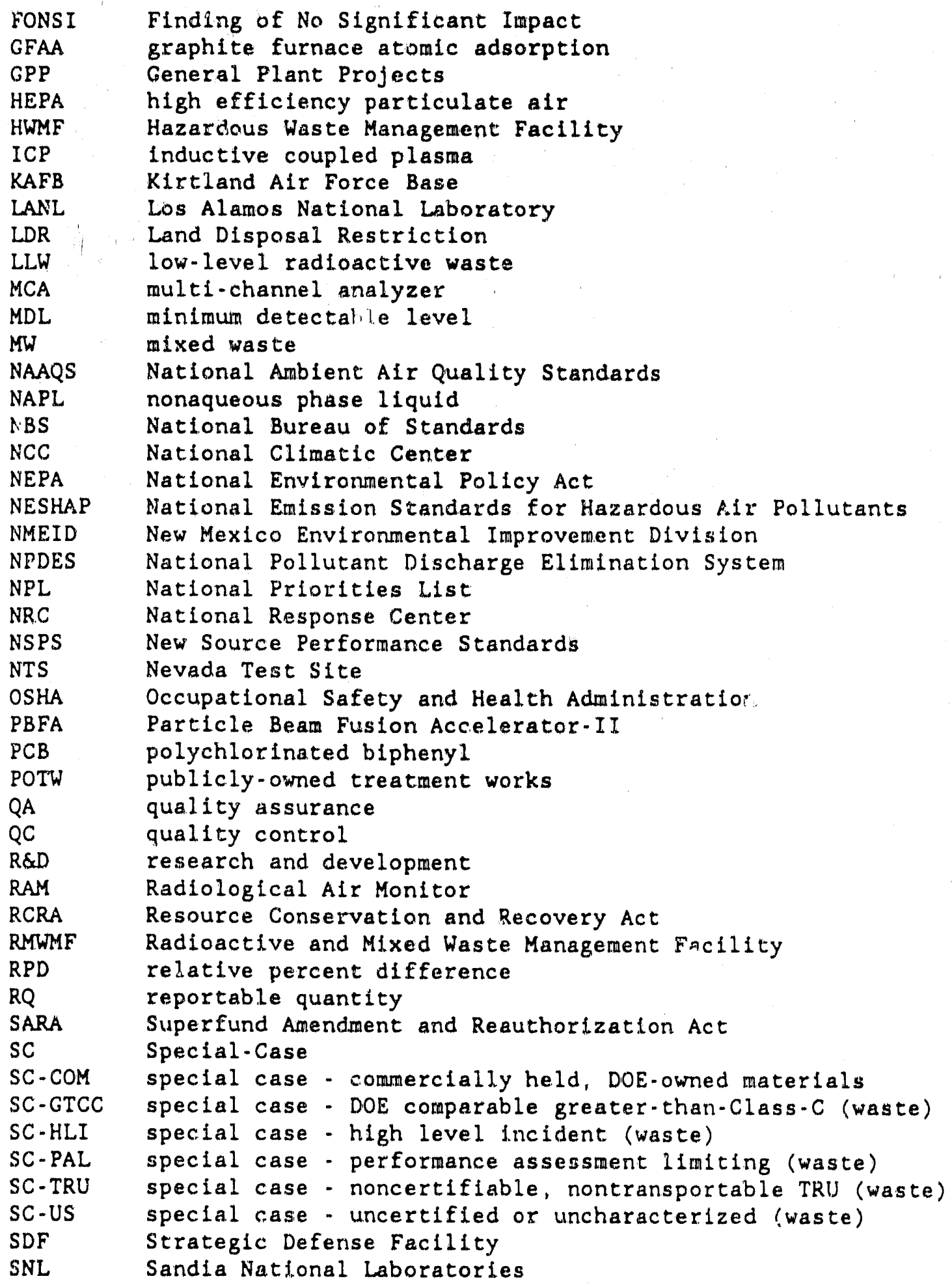




ABBREVIATIONS (Concluded)
Acronyms




\section{CHAPTER 1 EXECUTIVE SUMMARY}

\subsection{Assessment of Environmental Compliance Activities}

\section{Background}

Sandia National Laboratories, Albuquerque (SNL, Aibuquerque), operates in compliance with environmental requirements established by Federal and State statutes and regulations, Executive Orders, the U.S. Department of Energy (DOE), and a State of New Mexico Compliance Order. SNI, Albuquerque, has been issued environmental permits in compliance with air emissions, water discharge, and solid waste disposal regulations. Compliance is enforced by the U.S. Environmental Protection Agency (EPA), the State of New Mexico Environmental Improvement Division (NMEID), Berralillo County, and the City of Albuquexque (Section 3.2). The following summarizes the compliance status of SNL, Albuquerque, with the major environmental statutes.

Comprehensive Environmental Response Compensation and Liability Act (CERCLA)--SNL, Albuquerque, has negotiated with the other potentially responsible part involved in an offsite National Priorities List (NPL) location to relmburse the EPA for completed remedial actions. SNL, Albuquerque, has not been nominated for the NPL and does not expect to be in the future. Thus, alI Envixonmental Restoration (ER) Program activities will be directed by a Resource Conservation and Recovery Act (RCRA) Corrective Action permit provision.

Clean Air Act (CAA)--From the Albuquerque/Bernalillo County Air Quality Control Board, SNL, Albuquerque, perlodically recelves open-burning permi-: as well as top soil disturbance permits for the control of airborne particulates during constrwetion projects. SNL, Albuquerque, also complies with the National Emissions Standards for Hazardous Air Pollutants (NESHAP) for radionuclide air emissions (subpart $H$ ), beryllium air emissions (subpart C), and asbestos emissions (subpart M). In Apri1 1989, SNL, Albuquerque, obsained an NESHAP permit for radionuclides during the modification of the Particle Beam Fusion Accelerator (PBFA) II in Area IV.

Clean Hater Act (CWA)--SNL, Albuquerque, has five wastewater discharge permits frorn the City of Albuquerque for sanitary sewer discharges and has resolved past minor violations of the permits with the City of Albuquerque. Two surface impoundments are permitted and 65 septic tanks are registered with the NMEID. The NMEID has ruled that several categories of low volume and/or clean wastewater surface discharges require no discharge plans.

National Environmental Policy Act of 1969 (NEPA)--SNL, Albuquerque, is committed to the principles and practices underlying the National Environmental Policy Act of 1969 (NEPA); in 1989, there was a major increase in NEPA compliance. New guidance procedures were initiated. The number of Action Description Memorandums (ADMs) increased by 100 percent, 
and five environmental assessments (EAs) are under preparation for sulmittal to the DOE.

Resource Conservation and Recovery Act (RCRA)--SNL, Albuquerque, has inactive chemical waste landfills (CWL), mixed waste landfills (MWL), a storage facility, and a thermal treatment facility which are all permitted under interim status. Minor RCRA violations have been resolved with the State. The RCRA Part B Hazardous Waste Permit Application was deemed administratively complete by the State, and an informal public hearing was held on the application. Review of the permit application for technical adequacy is underway. A revised Part A permit application for hazardous waste and mixed waste was prepared for submission to the NMEID. An interim status permit was prepared for mixed waste storage and submitted to the DOE on February 9, 1990. At present, fifty-two underground storage tanks (USTS) are registered with the NMEID.

A groundwater monitoring compliance order was issued by the State. Corrective actions have been implemented. An agreement with the state concerning remaining corrective actions was completed on December 29, 1989, and signed on January 11, 1990.

The potential release sites identified by the ER Program will be evaluated and corrected as required by the RCRA $3004(u)$, Corrective Action for Releases from Solid Waste Management Units. A schedule for this corrective action will be a part of the final RCRA Pare B permit.

\section{Current Issues and Actions}

Mixed Waste Authority (RCRA)-. SNL, Albuquerque, recently submitted a Part A permit application for mixed waste (MW) storage and treatment to the DOE. The DOE will submit the Part $A$ application to the NMEID in calendar year 1990. As a matter of policy, SNL, Albuquerque, will comply with RCRA requirements for all storage and treatment activities.

Groundwater Monitoring (RCRA).- The State issued a Notice of Violation for groundwater monitoring violations in 1989, and since the corrective actions could not be completed within the statutory 30-day limit, the State subsequently issued a compliance order on the same matter. A compliance agreement between the DOE, SNL, and NMEID was signed on January 11, 1990, to close the Compliance Order. The Compliance Agreement included revising the Sandia Sarpling and Analysis Plan, installing a fourth downgradient monitoring well, and characterizing the uppermost aquifer at the CWL. SNL, Albuquerque, is currently working toward fulfilling the compliance agreement requirements.

Low-Leve1 Radioactive Waste (LLW) and Mixed Waste (MW) Disposal-.SNL, Albuquerque, will submit an application to the Nevada Test Site (NTS) for disposal of both Low-Level Radioactive Waste (LLW) and MW in 1990. Upon review and approval, all radioactive wasto sent to the NTS must meet the waste acceptance criteria set forth in NVO-325, "Nevada Test Site Defense Waste Acceptance Criteria, Certification, and Transfer Requirements." 
Land Disposal Restrictions (LDR'-. In 1984, Congress amended the RCRA by imposing a schedule for restrictions on the land disposal of hazardous waste. These rotrictions are roferred to collectively as land disposal restrictions (LDRs). On May 8, 1990, the final LDRs will be implemented, forbidding the land disposal of hazardous waste that does noc meet prescribed treatment standards. The DOE has subinitted a 2-yr national capacity variance for MW.

\subsection{Assessment of Radiological Impact for the Public}

SNI. Albuquerque, is located southeast of Albuquerque on Kirtland Air Force Base (KAFB). Because radionuclides are potentially released in small quantities from its research activities to offsite areas, SNL, Albuquerque, has maintained an environmental monitoring program for radiological sampling and survelllance. The program includes annual sampling and analysis for $3 \mathrm{H}$, gross alpha $(\alpha)$ and beta $(\beta)$, total uranium, and gamma isotopic in surface water, groundwater, soll, and vegetation. These samplings and analyses are performed around Albuquerque at SNL, perimeter, and community locations. All levels measured in 1989 in public areas were consistent with the average local radiation background levels measured in previous years.

A total of $8.8 \mathrm{CI}$ of $41_{\mathrm{Ar}}, 0.6 \mathrm{Cl}$ of $133 \mathrm{Xe}, 0.2 \mathrm{Ci}$ each of $13 \mathrm{~N}$ and $15 \mathrm{O}$ and $\mu \mathrm{Ci}$ amounts of $3_{\mathrm{H}}$ and depleted uranium were released as a result of SNL, Albuquerque, operations in 1989. The maximum whole-body dose calculated for an offsite residence is $8.8 \times 10^{-4} \mathrm{mrem}$, less than 0.004 percent of the $25 \mathrm{mrem} / \mathrm{yr}$ dose limit specified in NESHAP standards and DOE Orders (Appendix G, Table G-1). The total Albuquerque population recelved a collective dose of 0.097 person-rem during 1989 from SNL, Albuquerque, operations, whereas it recelved greater than 40,000 person-rem from natural background radiation (Chapter 5).

\subsection{Overview of 1989 Monitoring Results}

\section{Radiological Monitoring}

All of the 1989 radiological monitoring results were consistent with the results of the previous years, and all were well below the DOE derived concentration guides (DCGs) specified in DOE Order 5400.5, "Radiological Protection of the Public and the Environment," issued in February 1990.

Background levels of $137 \mathrm{Cs}$ from worldwide fallout were detected in vegetation and soll samples. Values in vegetation ranged from less than the minimum detectable level (MDL) to $0.18 \mathrm{pCi} / \mathrm{g}$. Values in soll ranged from 0.01 to $0.88 \mathrm{pCi} / \mathrm{g}$. Total urantum in soll ranged from 2.0 to $2.9 \mathrm{\mu g} / \mathrm{g}$ of dry soll. There was no statistical difference in results from SNL, perimeter, and community locations. They were consistent with naturally occurring uranium concentrations reported for solls in this area (LANL, 1981; Masada, 1964). 
Concentrations of $3 \mathrm{H}$ and $137 \mathrm{Cs}$ in regional surface and well waters were less than the MDL and are therefore well below DOE DCGs. Gross $\alpha$ and $\beta$ concentrations are used for screening purposes since no DCG values are avallable for them. The levels in well waters were below the screening levels of EPA primary drinking water standards ( $40 \mathrm{CFR} 141$ ) and required no investigation actions.

In 1989, external penetrating radiation doses for the Albuquerque community area averaged $93 \mathrm{mrem} / \mathrm{yr}$ as measured by the SNL, Albuquerque, environment thermoluminescent dosimeter (TLD) moniroring system. This is the natural background radiation dose rate for the region attributable to terrestrial and cosmic radiation. There was no statistically significant difference between the three Albuquerque locations (SNL, Albuquerque, perimeter, and comnunity) in the 1989 TLD results (Chapter 5).

\section{Nonradiological Monitoring}

Wastewater--Discharges by SNL, Albuquerque, to publicly-owned treatment works (POTW) are regulated by the Clty of Albuquerque. During 1989, SNL, Albuquerque, operated under five wastewater discharge permits issued by the City. A sixth permit was obtained in August 1989. Detailed results are listed in Appendix $F$.

The 1989 wastewater monitoring results were within the permit conditions except for a few cases of $\mathrm{pH}$, fluoride, and copper exceedances (Chapter 6). Sume of the $\mathrm{pH}$ excursions were due to equipment malfunction. The corrective actions were taken after the problems were identified.

The annual $24-\mathrm{hr}$ composite sampling for all parameters specified in the City permits was conducted during June 1989. The results were all less than the concentration limits established by the permits. The results are summarized in Appendix G, Table G.3.

Surface Water--Nonsanitary discharges to surface impoundments are under the authority of the State of New Mexico. A Discharge Plan (DP.530) covering two lagoons in Area IV was approved in March 1988 and amended in December 1989 by the State. Monthly water level measurements and quarterly analysis were all within the parameters and concentration limits specified in DP530. Quarterly reports that include the surface water sampling and analyses were submitted to the NMEID Ground Water Bureau.

Air Quality--Air quality, except for radionuclide emissions, is regulated by the City of Albuquerque. Ambient air monitoring throughout the City is conducted by the Air Pollution Control Division of the City. SNL, Albuquerque, does not maintain any ambient air samplers onsite. Alrborne emissions sampling was performed according to permit specifications. During 1989, a beryllium air emission test was performed for the Building 869, Toxic Machine Shop. The results were all within the regulatory limits specified in 40 CFR 61 subpart $C$ for beryllium emission. A SNL-wide inventory of air emissions was started in October 1989. This inventory 
will survey estimated quantities of potentially hazardous air pollutants and associated control and stack information. The inventory is expected to be completed in 1990 . 


\section{CHAPTER 2}

\section{INTRODUCTION}

\subsection{Site Operation}

SNL, Albuquerque, is operated by Sandia Corporation, a prime contractor of the DOE. Sandia Corporation, which is a subsidiary of AT\&T Technologies, Inc., provides service to the U.S. Government on a nonprofit, no-fee basis. The major responsibilities are national security and energy projects (ERDA, 1977). Its mission includes the weaponization of nuclear explosives and the designing of arming, fusing, and firing systems used in nuclear bombs and warheads. Safety, rellability, and survivability of weapon systems receive primary emphasis.

Other projects include nuclear reactor safety studies for the U.S. Nuclear Regulatory Commission; development of safe transport ard storage systems for special nuclear materials including plutonium and uranium; radioactive waste disposal techniques and site studies; pulsed power research; thermonuclear fusion research; solar energy research; vertical axis wind turbine research; and fossil fuel and geothermal energy research.

\subsection{Location and Population}

SliL, Albuquerque, is located in Bernalillo County at the foot of the Manzano Mountains adjacent, to Albuquerque, New Mexico. At their nearest points, SNL facilities are $2-1 / 2 \mathrm{mi}$ south of Interstate 40 and approximately 6-1/2 mi east of downtown Albuquerque (Figure 2-1). The facilities are surrounded by KAFB East, with co-use agreements on some Air Force property. An area of the Manzano Mountains east of KAFB has been withdrawn from the Forest Service for the exclusive use of the Air Force and the DOE.

The laboratory consists of five technical areas and several remote test areas situated in the eastern half of the $190-\mathrm{km}^{2}$ KAFB military reservation. KAFB is located on two broad mesas bisected by the Tijeras Arroyo, an east-west canyon. These mesas are bound by the Manzano Mountains (Cibola National Forest) to the east and the Rio Grande River to the west. Elevations range from a low of $1,500 \mathrm{~m}$ at the Rio Grande River to a high of $3,255 \mathrm{~m}$ at Sandia Crest, which is in the Sandia Mountains adjacent to Albuquerque. KAFB is at a mean elevation of $1,630 \mathrm{~m}$.

The largest population center in Bernal1110 County, and also the closest population center to KAFB, is Albuquerque, located slightly north of the base. The 1980 census figures show an Albuquerque population of 331,767 (U.S. Department of Commerce, Bureau of the Census, 1981). The Isleta Indian Pueblo, which borders KAFB on the south, is the next nearest population center with a 1980 census of 1,872. An estimated total population of 450,000 people lives within an $80 \mathrm{~km}$ radius of KAFB (U.S. Department of Commerce, Bureau of the Census, 1981). This includes permanent residents of KAFB living in the KAFB housing areas. 


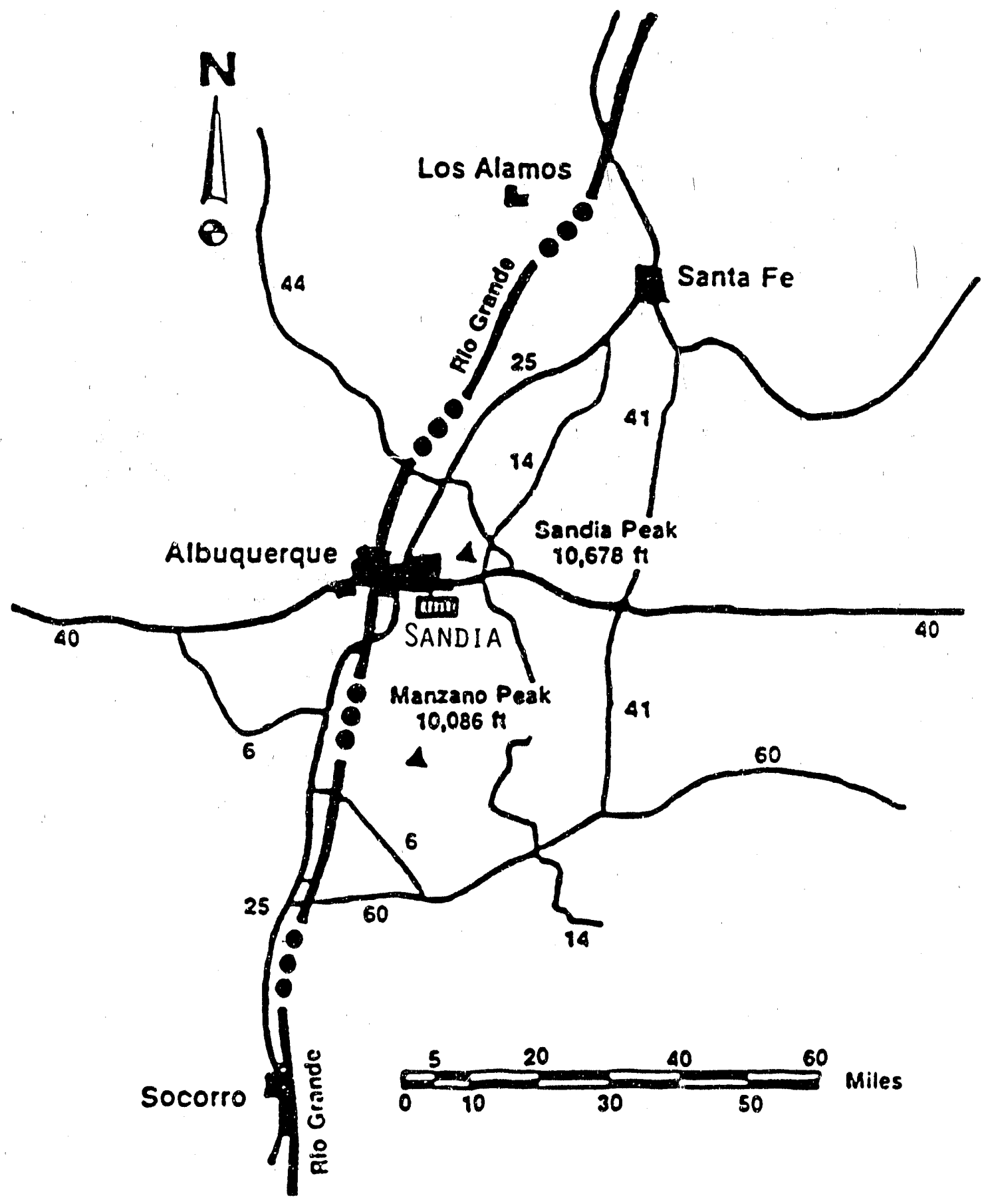

Figure 2-1. Albuquerque Site Regional Setting 


\subsection{Climate and Meteorology}

Albuquerque temperatures are characteristic of high altitude, dry, continental climates (Appendix A). Daily temperatures are wide-ranging, although temperature extremes such as $-18^{\circ} \mathrm{C}$ and $38^{\circ} \mathrm{C}$ occur infrequently (Table A-1). Daytime temperatures during the winter average near $10^{\circ} \mathrm{C}$. Maximum summer daytime temperatures average less than $32^{\circ} \mathrm{C}$ except in July, when the maximum reaches $34^{\circ} \mathrm{C}$. The average annual precipitation is $21 \mathrm{~cm}$; half of this precipitation occurs from July through September in the form of brief thundershowers. Winter months are typically dry with less than $5 \mathrm{~cm}$ of precipitation normally recorded. The average annual relative humidity is about 43 percent (Table A-2), although the humidity drops to less than 20 percent in April, May, and June. Strong winds, often accompanied by blowing dust, occur mostly in late winter and early spring (NOAA, 1983; 1968). The wind speed reaches $13.3 \mathrm{~m} / \mathrm{s}$ for less than 48 days each year. Prevailing surface winds on KAFB are from the east (Figure 2-2) (0lson et al., 1970). Rapid nighttime ground cooling produces strong temperature inversions as well as strong drainage winds down $\mathrm{T} i \mathrm{j}$ eras Canyon.

Table 2-1 summarizes meteorological data for 1989. The total annual precipitation of $12.1 \mathrm{~cm}$ for 1989 was $8.5 \mathrm{~cm}$ below the $30-\mathrm{yr}$ annual average of $20.6 \mathrm{~cm}$ (see Appendix A, Table A-1).

\subsection{Geology}

The SNL, Albuquerque facilities are lacated within the Albuquerque Basin, which is bounded by the Sandia, Manzanita, and Manzano Mountains to the east and the Lucero and Jemez uplifts (or mesas) to the west. The Albuquerque basin consists of approximately $12,000 \mathrm{ft}$ of Miocene-P1ioceneSanta Fe alluvial and colluvial sediments. The basin deposits were formed by a complex mixture of aeolian, channel, debris flow, levee, and floodplain mechanisms.

The general stratigraphy of sediments consists primarily of deposits of sands and gravels interbedded with silt and clay rich zones. The observation of sequences fining upward in the stratigraphy is important in that typically these deposits have lenticular shapes in cross section. The nature of the cross sections observed in the drilling activities confirmed the presence of sedimentary deposits and silt and clay rich zones, which were discontinuous across the site.

\subsection{Hydrology and Biology}

The major hydrologic surface feature in Central New Mexico is the Rio Grande River, which runs north-south through Albuquerque and is approximately $8 \mathrm{~km}$ west of KAFB (Albuquerque District Corps of Engineers, 1979). Rio Grande water is primarily used for irrigation of agricultural crops. There are no continuously running streams on KAFB. Tijeras Arroyo has intermittent flow during heavy thundershowers. 


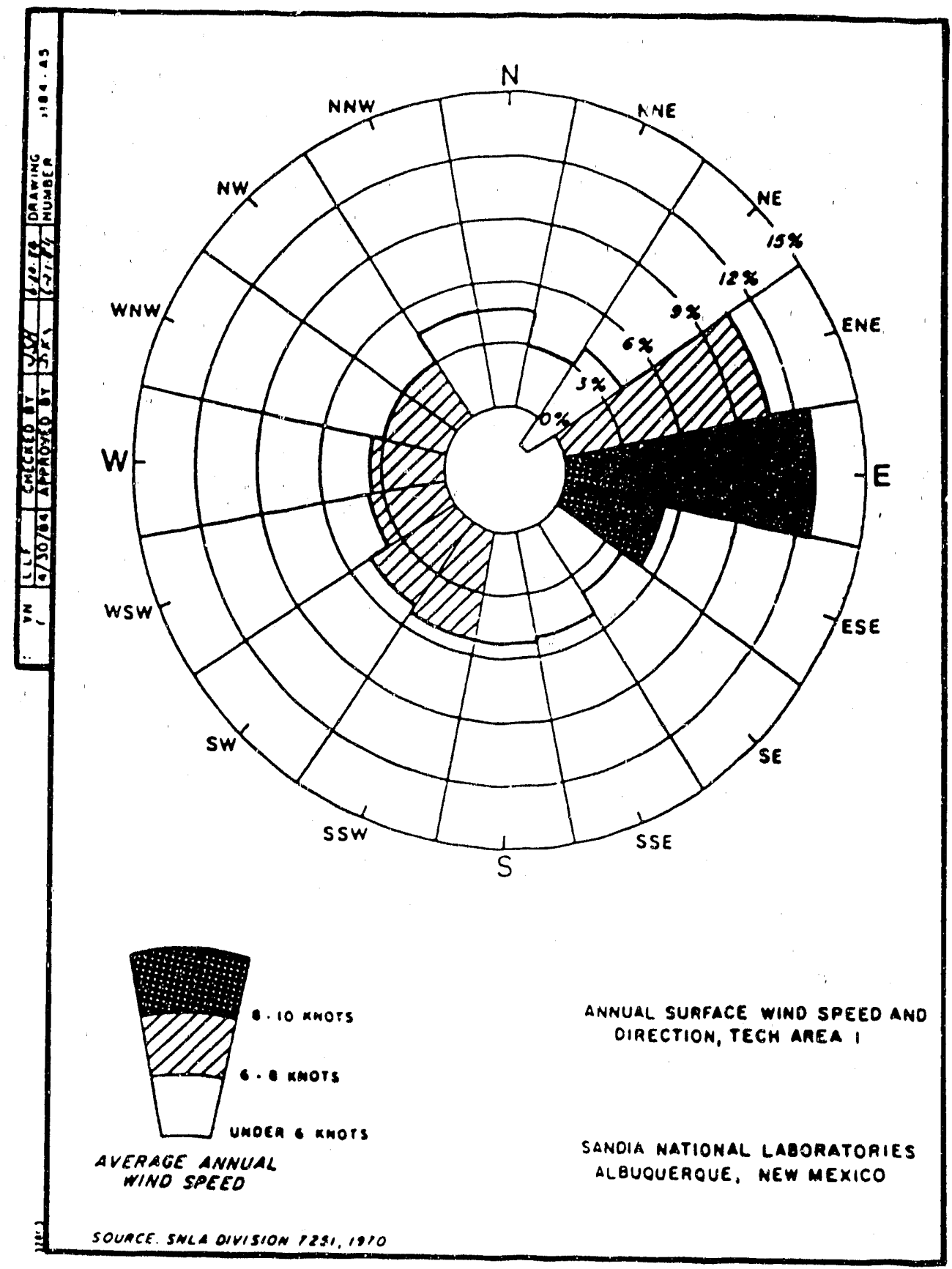

Figure 2-2. Annual Surface Wind Speed and Direction, Technical Area I 
Table 2-1. Summaty Meteorological Data for the Albuquerque Area in 1989

\begin{tabular}{|c|c|c|c|c|c|}
\hline \multirow[b]{2}{*}{ Month } & \multicolumn{2}{|c|}{ Temperatures $\left({ }^{\circ} \mathrm{C}\right)$} & \multirow{2}{*}{$\begin{array}{l}\text { Precipitation } \\
\text { (cm) Water } \\
\text { Eqixivalenc }\end{array}$} & \multicolumn{2}{|c|}{ Wind } \\
\hline & $\operatorname{Min}^{D}$ & $\begin{array}{l}\text { ge } \\
\text { Max }\end{array}$ & & $\begin{array}{c}\text { Speed } \\
\mathrm{m} / \mathrm{s}\end{array}$ & Direction \\
\hline $\begin{array}{l}\text { Jan } \\
\text { Feb } \\
\text { Mar }\end{array}$ & $\begin{array}{r}-5.0 \\
-1.7 \\
2.6\end{array}$ & $\begin{array}{r}8.8 \\
12.7 \\
20.4\end{array}$ & $\begin{array}{l}0.82 \\
0.89 \\
1.22\end{array}$ & $\begin{array}{l}3.7 \\
4.0 \\
4.0\end{array}$ & $\begin{array}{l}\mathrm{N} \\
\mathrm{NW} \\
\mathrm{SW}\end{array}$ \\
\hline $\begin{array}{l}\text { Apr } \\
\text { May } \\
\text { Jun }\end{array}$ & $\begin{array}{r}7.2 \\
11.4 \\
15.9\end{array}$ & $\begin{array}{l}25.4 \\
29.5 \\
32.5\end{array}$ & $\begin{array}{c}T^{*} \\
0.05 \\
0.05\end{array}$ & $\begin{array}{l}5.0 \\
5.3 \\
5.2\end{array}$ & $\begin{array}{l}\mathrm{W} \\
\mathrm{S} \\
\mathrm{SE}\end{array}$ \\
\hline $\begin{array}{l}\text { Jul } \\
\text { Aug } \\
\text { Sep }\end{array}$ & $\begin{array}{l}18.3 \\
16.5 \\
13.3\end{array}$ & $\begin{array}{l}33.4 \\
30.4 \\
28.2\end{array}$ & $\begin{array}{l}3.83 \\
1.22 \\
0.79\end{array}$ & $\begin{array}{l}4.2 \\
4.2 \\
4.2\end{array}$ & $\begin{array}{l}S E \\
S E \\
S E\end{array}$ \\
\hline $\begin{array}{l}\text { Oct } \\
\text { Nov } \\
\text { Dec }\end{array}$ & $\begin{array}{r}6.5 \\
0.3 \\
-5.3\end{array}$ & $\begin{array}{r}20.8 \\
15.7 \\
8.7\end{array}$ & $\begin{array}{c}2.46 \\
\mathrm{~T} \\
0.71\end{array}$ & $\begin{array}{l}3.6 \\
3.8 \\
3.1\end{array}$ & $\begin{array}{l}\mathrm{N} \\
\mathrm{N} \\
\mathrm{N}\end{array}$ \\
\hline
\end{tabular}

The uppermost aquifer underlying the site is approxinately $480 \mathrm{ft}$ below the ground surface. Some perched aquifers have been detected in the zone between the main aquifer and the ground surface. Although no drilling has been performed, it is possible that the entire $12,000 \mathrm{ft}$ of the Santa Fe formation contains groundwater.

The groundwater underlying SNL facilities is separated into two systems by major faulting. The Hubble Springs, Tijeras, and Sandia faults separate the hydrogeology into a somewhat deep region west of the fault systems and a much shallower region on the east side. The CWL and many of the SNL facilities are located west of the fault systems in the area of deeper groundwater.

West of the fault systems, the groundwater flows in a northwesterly direction. Prior to the growth of the City of Albuquerque, the flow was reported to be more westerly. Albuquerque provides all of its drinking water from the groundwater, and pumping from municipal supply wells has significantly altered the flow direction. 
'The hydrology east of the fault systems is poorly understood because there are a limited number of water supply wells, no monitoring wells, and the geology between the fault systems and the mountains is very complex. The SNL facilities located in this area are generally in the canyons of the Manzanita Mountains. The groundwater flow would typically be out of the canyons and toward the fault systems.

The municipal and domestic water needs of the Albuquerque vicinity are supplied by deep wells. These wells range from 148 to $365 \mathrm{~m}$ in depth, with an average depth of $305 \mathrm{~m}$.

New Mexico has low precipitation, wide temperature extremes, frequent drying winds, heavy showers with erosive effects, and erratic seasonal distribution of precipitation. This semidesert southwest climate combines with the low-water availability to produce many species of droughtresistant flora such as cacti (ERDA, 1977).

The mesa vegetation on KAFB, consisting if grasses and shrubs, is illus. trated in Figure 2-3. Figure 2-4 shows juniper trees and cacti that are present at the higher elevations bordering the mountains east of KAFB. Russian thistle (tumbleweeds) proliferate in mechanically disturbed areas. The City of Albuquerque, adjacent to KAFB, has flora typically found in urban environments.

\subsection{Technical Areas}

SNL, Albuquerque (Figure 2-5), consists of five technical areas and several additional test areas. Each area has its own distinctive operations. The following is a brief description of the activities in each area and a summary of potential sources for radioactive and nonradioactive effluent releases.

\section{Area I}

Area I has the largest employee population: approximately 5,000. This area is dedicated primarily to the design, research, and development of weapon systems, limited production of weapon system components, and energy programs. It also includes laboratories and shops used by administrative and technical staff. Generally, the only potential radioactive release from Area $I$ is tritium $\left({ }^{3} \mathrm{H}\right)$ from two laboratory sources; however, no $3_{\mathrm{H}}$ was released from these stacks in 1989. Potential sources for nonradioactive effluents include the paint shops, toxic machine shop, process development lab, emergency diesel genexator plant, solvent spray booth, foundry, and steam plant.

\section{Area II}

Area II is a sinall facility used for explosive testing. Microcurie amounts of tritium may be released each year from component testing. Techniques for measuring fractures in geologic strata are developed at this facility. Also located in Area II are an inactive LLW disposal site, a small 


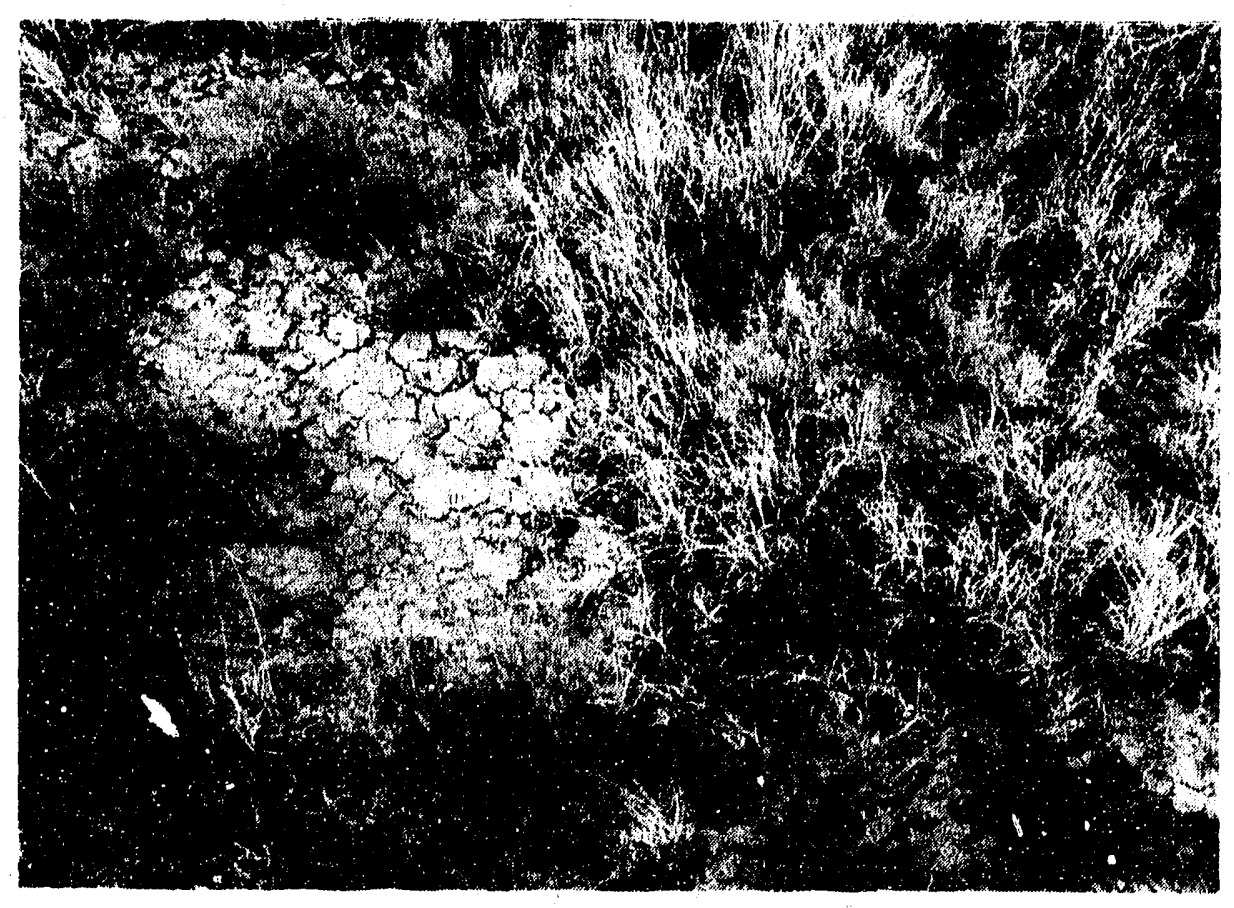

Figure 2-3. Mesa Vegetation

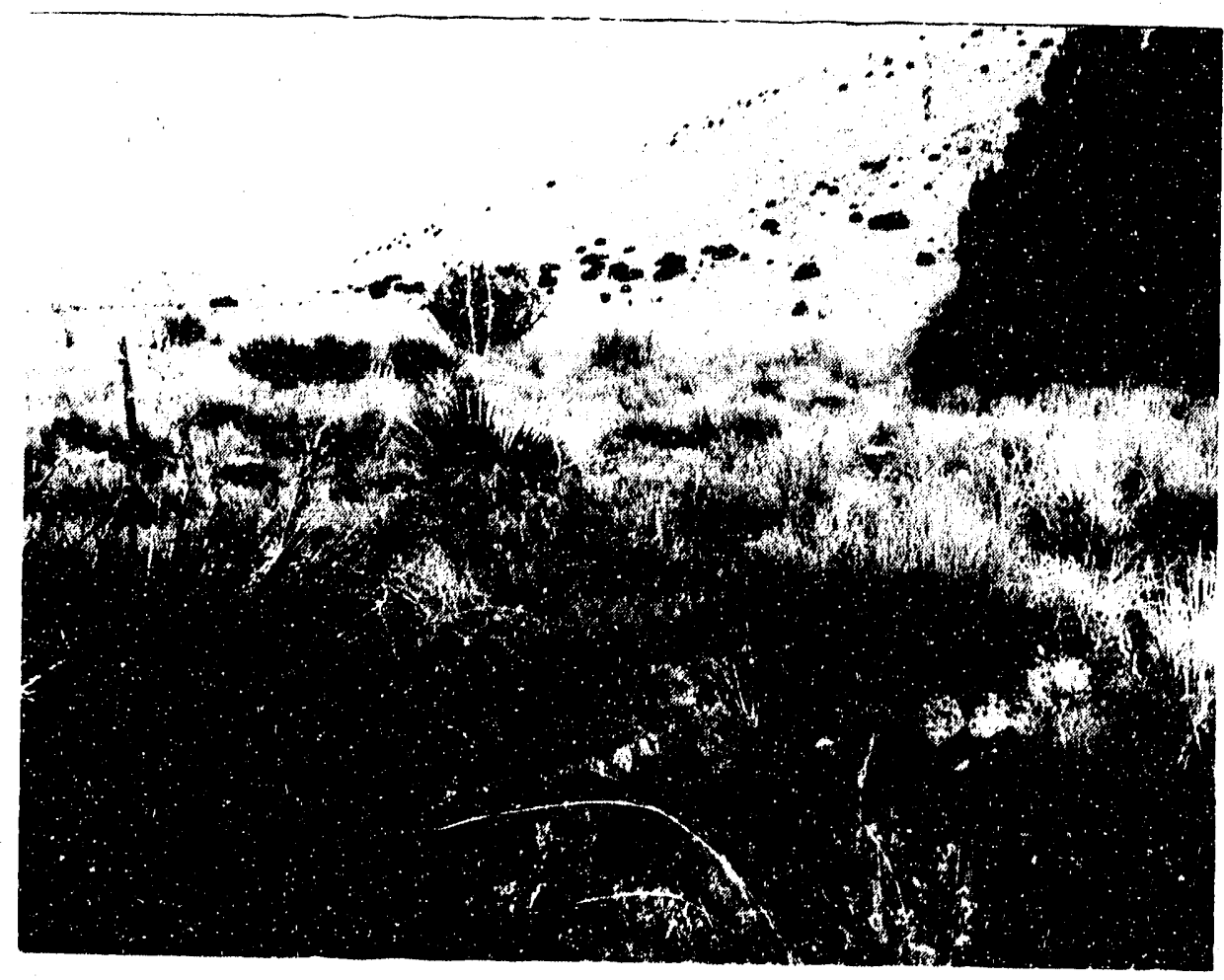

Figure 2-4. Manzano Foothills Vegetation 


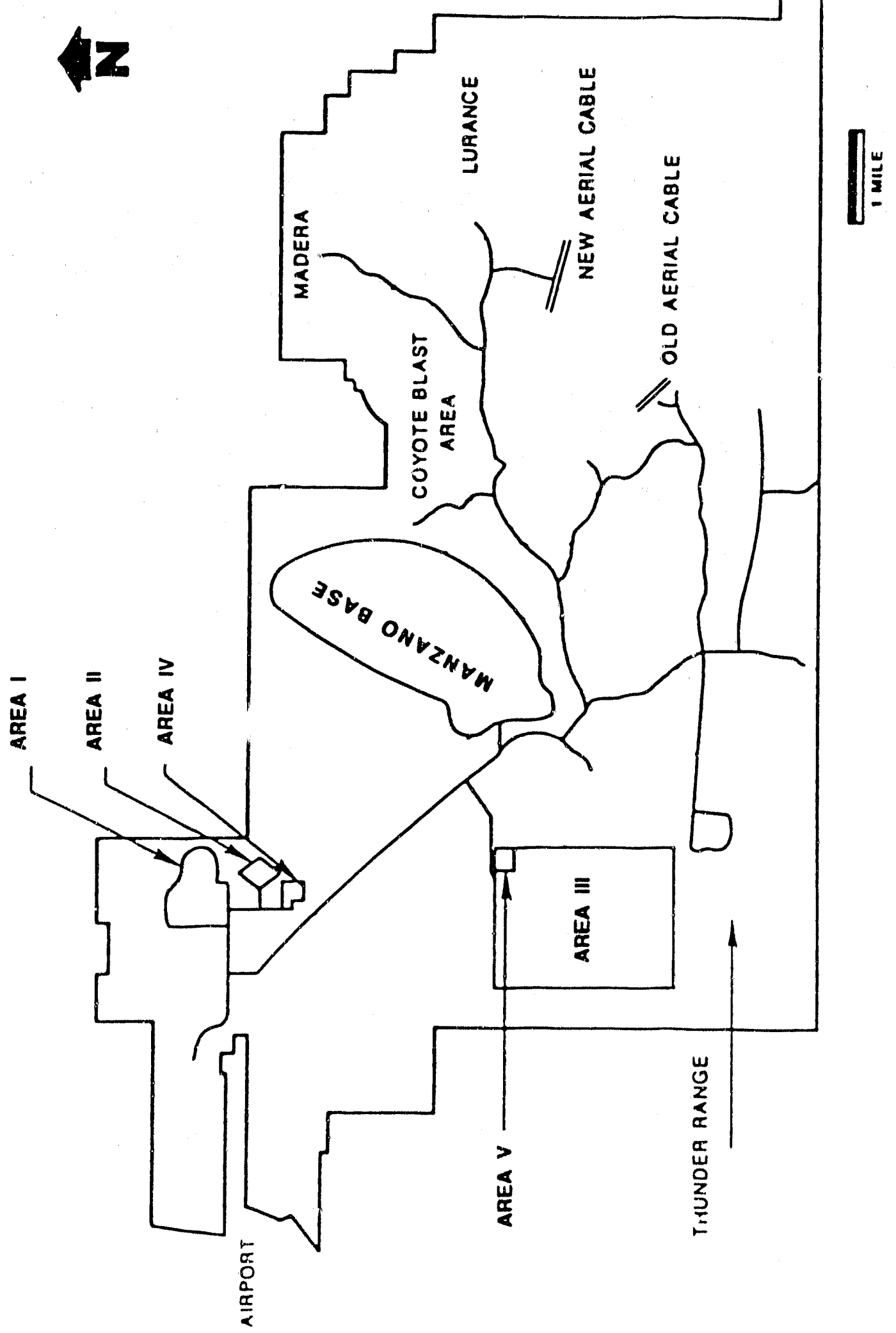

告 
radioactive material decontamination and storage facility, and a storage facility designed to temporarily hold folychlorinated biphenyl (PCB)contaminated materials to be transported to an EPA-licensed disposal facility. The inactive LLW disposal site has not been used for over 20 yr. A new facllity, the Explosive Components Facility (ECF) is planned for Area II. This facility will integrate many of the existing Area II activities as well as some remote testing activities currently performed in other test areas.

Area III

Area II: ls located $8 \mathrm{~km}$ south of Area I. It is comprised of 20 test facilities whicin include extensive environmental test facilities (such as sled tracks, centrifuges, and a radiant heat facllity). No radioactive effluents are released through normal operations in the area. During 1989 , there was a total of four NIKE motor tests that released 3.73 lb of lead per test at the sled-track area. Other facilities in Area III include a paper incinerator, an inactive $L L W$ and $\mathrm{MW}$ disposal site, a large melt facility, and a Melting and Solidification Laboratory.

The Inactive radioactive waste disposal site in Area III consists of two adjoining fenced areas that occupy approximately 0.6 ha (SNL, Albuquerque, 1989). One area was used for LLW disposal in seven shallow trenches. The second area was used for disposal of classified LLW in 37 pits. The LLW consisted primarily of tritium contaminated materials. Three additional pits located in the classifled waste disposal area were used exclusiveiy for natural and depleted uranium waste disposal. The site is scheduled for closure by 1991. It is currently used as an interim storage facility for radioactive and MW. LLW will be stored at a new radioactive and MW storage facility which is scheduled for completion and use in the late fiscal year 1990. This new facility is located at the south end of irea III adjacent to the inactive chemical disposal site.

An inactive hazardous waste disposal and storage site is located near the southern boundary of Area III (SNL, Albuquerque, 1989). This facility has not been used for disposal of hazardous wastes since November 7,1985 . It was used as an interim hazardous waste storage area from 1985 to 1988. A Closure Plan and Post-Closure Permit Application was prepared in May 1988 for the no-longer-used hazardous waste disposal site. A new hazardous waste repackaging and storage bullding, located south of Area I, has been in use since 1988.

Area IV

Arba IV consists of several Inertial confinement fusion research and pulsed power research facilities. One large accelerator, the Particle Beam Fusion Accelerator-II (PBFA-II), was completed in 1985. Gaseous tritium effluents (primarily HT) will be released from fusion research efforts starting 1991. A large accelerator facility, the Simulation Technology Laboratory (STL), houses seven pulsed power accelerators: HERMES III, RLA, TROLL, STF, SFEED, HYDRAMITE, and in 1989, PROTO II. Several of these accelerators 
have been transferred from Area V. HERMES III became operational in 1988. Another new accelerator facflity, SATURN, was also completed in 1987. There, were minimal radioactive releases from these facilities in 1989. A major new research facility, the Strategic Defense Facility (SDF), is under construction and will be operational by 1990. During 1989, radioactive emmissions from this facility were short-lived radionuclides, primarily $13 \mathrm{~N}$ and 150 .

Area V

Area $V$ houses large electron beam accelerators, three research reactors in two reactor facilities, an intense gamma irradiation facility (usirig $60^{\circ} \mathrm{Co}$ and $137 \mathrm{Cs}$ ), and a hot cell facility. The largest accelerator is HERMES II. These facilities have been transferred to Area IV except for HERMES II. No tritium was released in 1989, nor has there been for several years due to the nature of current research efforts.

The two research reactor facilities in Area $V$ are quite dissimilar: the Sandia Pulsed Reactor (SPR) is an unreflected, unmoderated assembly of enriched uranium; the Annular Core Research Reactor (ACRR) is an annular core of 226 fuel elements in an open water tank. Both the SPR and ACRR air exhaust systens are equipped with particulate effluent samplers. The ACRR also has a continuous gaseous effluent monitor. The only airborne releases are air activation products from reactor operations primarfly composed of $41_{\mathrm{Ar}}$ and $133 \mathrm{Xe}$. The reported amount of $41_{\mathrm{Ar}}$, released from both reactor areas, was computed from reactor operating parameters. The reported releases from both reactors for 1989 were very small ( $8.8 \mathrm{CI}$ ) anil were not significantly different from previous releases.

\section{Remote Test Areas}

SNL, Albuquerque, also has test areas outside of the five technical areas. These areas are located south of Area III and in canyons on the west side of the Manzano Mountains. Coyote Canyon and Thunder Range are two examples of such areas (Figure 2.5). In these remote areas, wild animals including snakes, deer, coyote, and owl are often present. Figures 2-6, 2-7, 2-8, and 2-9 show the presence of some of these wild animals near the Coyote test field, Thunder Range, and Solar Tower areas.

Depleted uranium is infrequently spread over limited areas during explosive testing in these remote test areas. The test areas are surveyed following each test, and contaminated materials are collected and disposed in accordance with DOE requirements. Environmental monitoring is done as necessary. Operations in these areas are, in addition, administratively controlled to avoid uranium contamination to public areas beyond the confines of KAFB. 


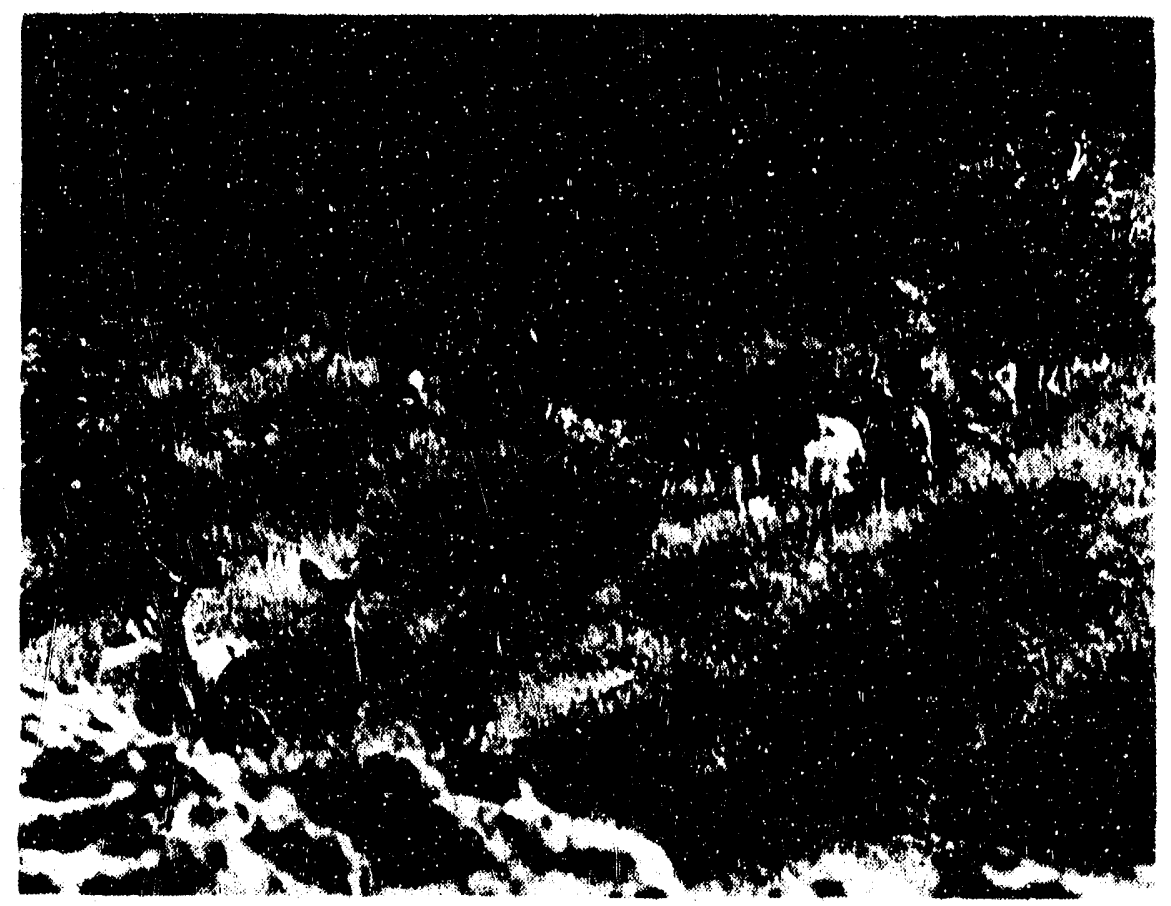

Figure 2-6. A Group of Deer at the Main Burn Site in Coyote Test Field

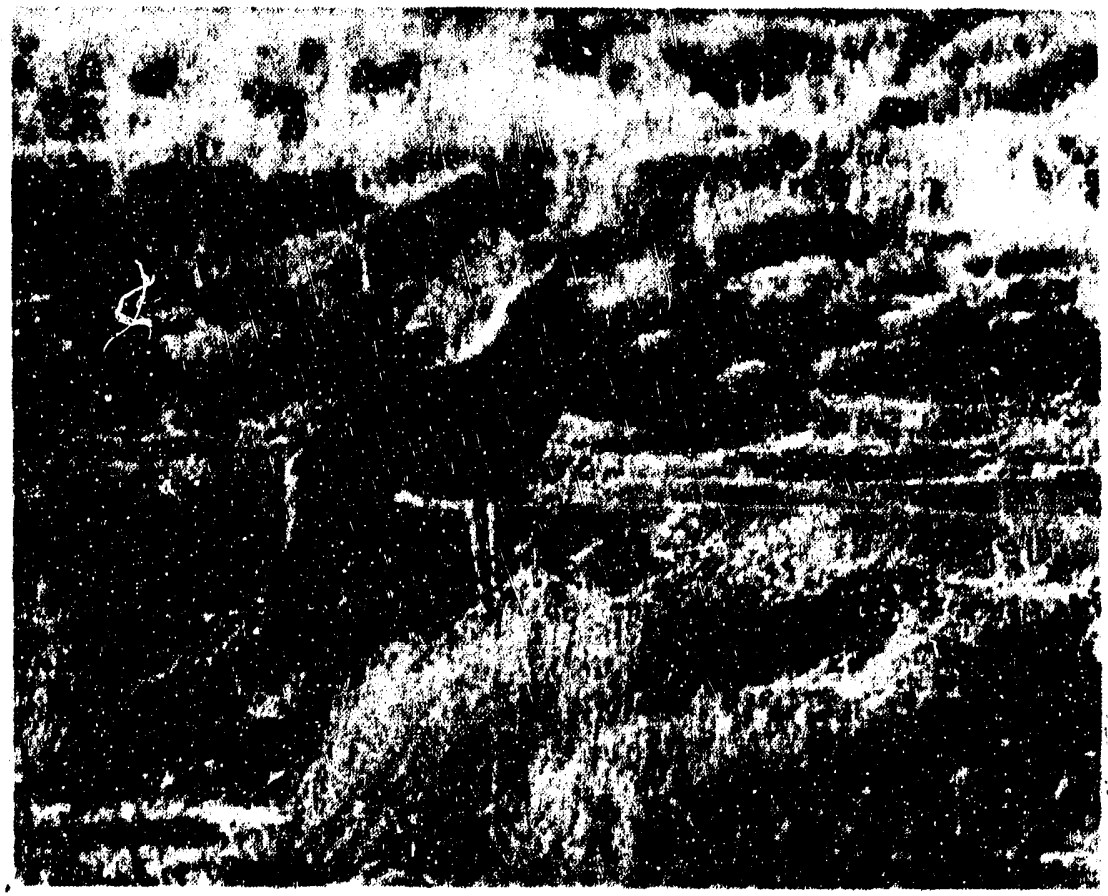

Figure 2-7. Coyote Wandering Near Solar Tower, Technical Area III 


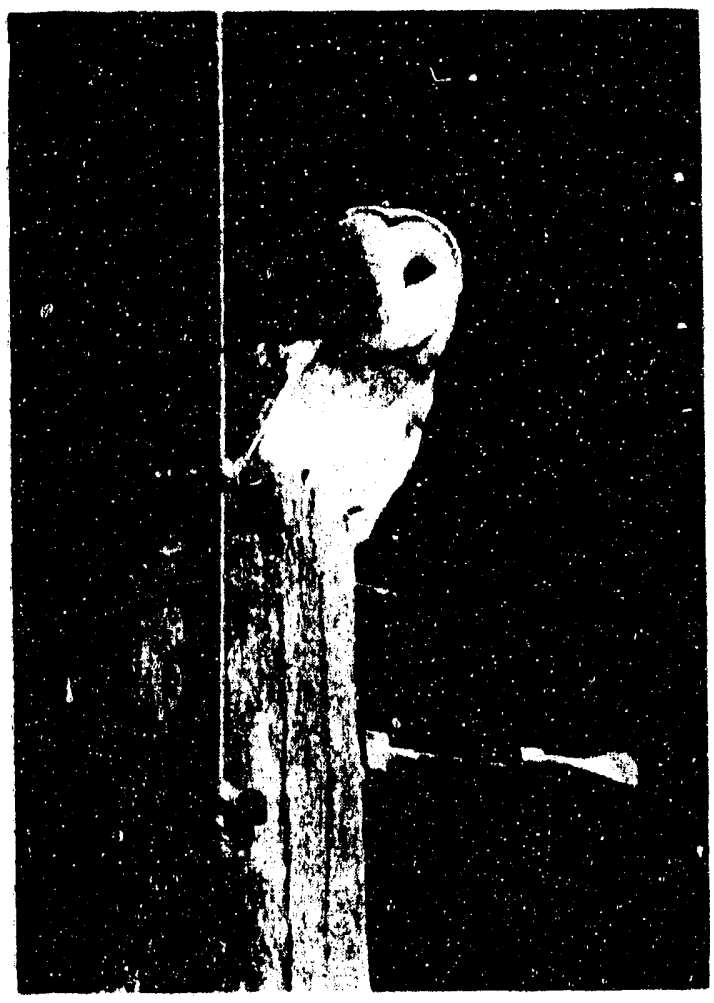

Figure 2-8. An Owl Sitting on a Telephone Pole Near Thunder Range

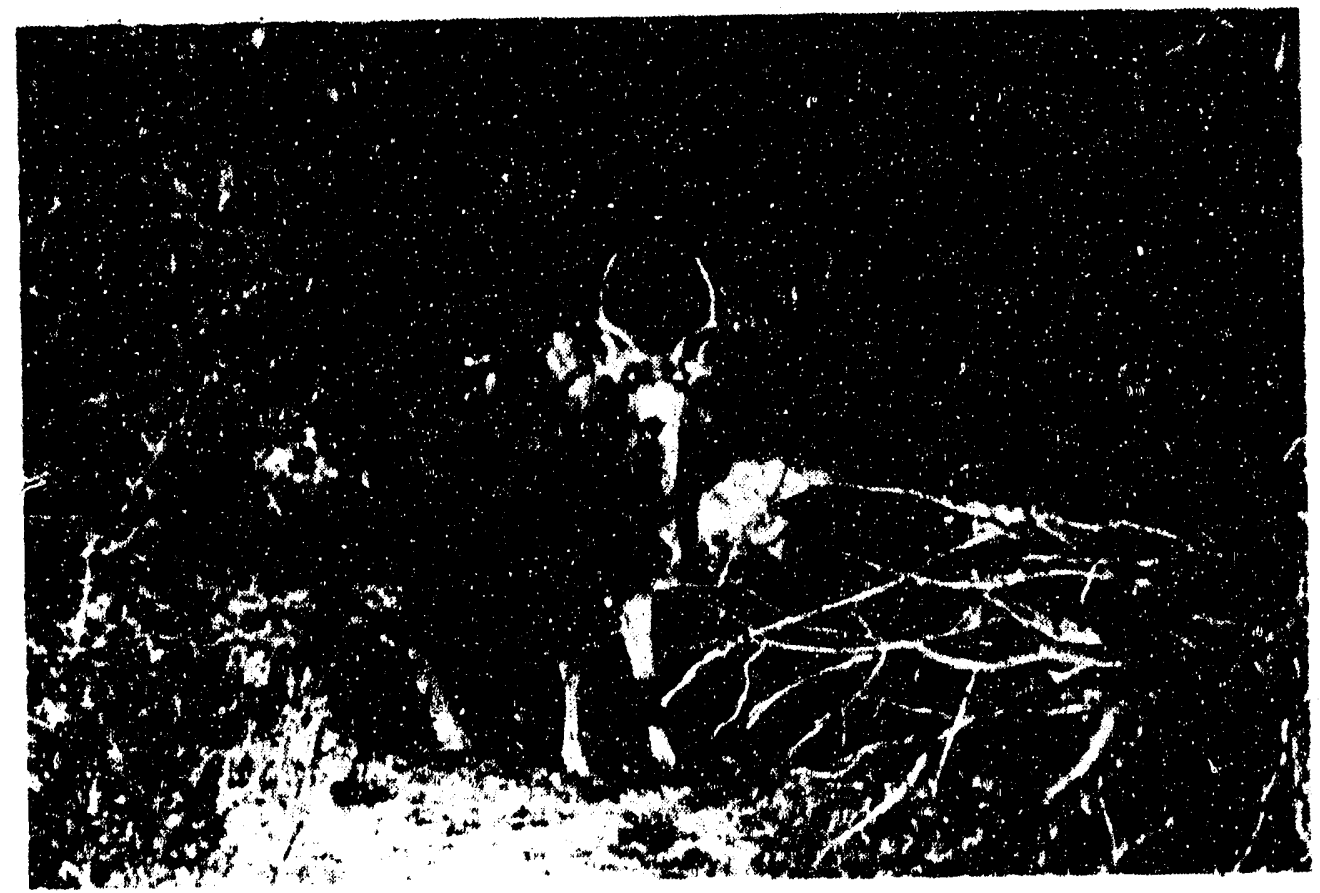

Figure 2-9. Deer at Coyote Canyon 


\section{CHAPTER 3 \\ SUMMARY OF SIGNIFICANT ENVIRONMENTAL ACTIVITIES}

The environmental compliance activities at SNL, Albuquerque, are administered by the newly formed 1989 Environmental Programs Department 3220. The Department consists of three divisions: 3221, Hazardous Waste and Wastewater Division; 3222, Radioactive and Mixed Waste Division; and 3223, Environmental Impact and Restoration Division. This chapter summarizes all significant environmental compliance activities that occurred during 1989.

\subsection{NEPA Compliance and Documentations}

The NEPA, the nation's most comprehensive legislative and public policy statement on environmental protection, applies to all agencies of the Federal government. Executive and DOE orders apply NEPA and NEPA-related activities to SNL, Albuquerque. The Council on Environmental Quality (CEQ) was created in the Executive Office of the President under the authority of NEPA. CEQ regulations were formally adopted by the DOE in August 1979.

Environmental documents serve as vehicles for presentation and review of the environmental issues associated with projects. Division 3223 of the Environmental Programs Department consults and trains line organizations in NEPA, coordinates NEPA document preparation, maintains a corporate NEPA document file, and reviews all NEPA documents before their submittal to the DOE.

\section{Activities}

In late 1989, a staff member was assigned full-time to NEPA coordination for SNL, Albuquerque. An assessment of compliance and guidance procedures was performed to improve document quality and to eliminate situations where delays could cause undue pressure to expedite work. A Sandia Compliance Strategy and NEPA Compliance Guide was prepared as a result of the assessment. The guidance was designed to improve document quality and expedite the review process.

At the DOE's request, a standard operating procedure was written in November 1989 for the preparation of ADMs and permitting procedures for burn tests. The documents outlined procedures to streamline the process for approving ADMs and open burning permits.

The status of NEPA documentation at SNL, Albuquerque, from January 1, 1985, through August 1989 was reviewed at the direction of the DOE. Active General Plant Projects (GPP) were reviewed for NEPA compliance in December 1989. 
Consistent with a U.S. Department of Energy, Albuquerque Office (DOE/AL) memorandum of April 17, 1989, archaeological surveys for all construction projects were prepared through Facilities Engineering. The survey reports have been integrated into NEPA documentation.

In 1989, SNL, Albuquerque, initiated a program to increase employee awareness of NEPA responsibilities. The training initiative culminated in a day-long workshop held on November 30, 1989, titled "Compliance With the National Environmental Policy Act."

\section{Environmental Assessments (EAs)}

The primary role of an Environmental Assessment (EA) is to determine the potential impact of a proposed action on the human environment. An EA is a "concise public document" that is intended to provide sufficient evidence and analysis for determining whether to prepare an environmental impact statement (EIS) or a Finding of No significant Impact (FONSI). EAs are being written for a number of facllities at SNL, Albuquerque. These documents are designed to (1) reduce the number of ADMs needed, and (2) facilitate the application of appropriate categorical exclusions. EAs are currently being prepared for these facilities:

- The Kauai Test Facility; this EA is expected to be sent to the DOE in June 1990.

- The Lurance Canyon Burn Site; the draft EA was sent to the DOE in May 1990.

- The ECF; this EA is expected to be completed by August 1990.

- The Integrated Materials Research Laboratory; the EA was submitted to the DOE in April 1990.

- The Radioractive and Mixed Waste Management Facility (RMWMF); the EA was submitted to the DOE in February 1990.

Action Description Memoranda (ADMs)

ADMs are used by the DOE to the determine the appropriate level of NEPA documentation for proposed actions and to support memo-to-file reviews. The number of ADMs written in 1989 increased and the quality of the documents written improved as a result of activities to increase NEPA awareness. The 26 ADMs written or approved in 1989 and their approval status are 1isted in Appendix I, Table I-1. Between 1988 and 1989, there was a 100 percent increase in the number of ADMs submitted to the DOE for approval. 


\subsection{Environmental Permits}

The following are the laws and regulations under which environmental permits are held by SNL, Albuquerque, as part of its commitment to full compliance with all applicable environmental laws and regulations.

\section{A. Air}

"The Clean Air Act (CAA) is enforced by the NMEID and the joint Albuquerque/Bernalillo County Air Quality Control Board. They regulate the following:

1. National Ambient Air Quality Standards (NAAQS);

2. NESHAP, except for the radionuclide NESHAP, which is administrated by EPA Region VI (Dallas);

3. New Source Performance Standards (NSPS), which regulate atmospheric emissions from certain types of facilities;

4. Open burning permits;

5. Nitrogen dioxide emissions from gas-burning equipment; and

6. Top soil disturbance permits.

B. Water

1. The Clean Water Act (CWA) is administered through EPA Region VI. The act encompasses the following regulations:

a. National Pollutant Discharge Elimination System (NPDES), including pretreatment effluent guidelines and standards;

b. NPDES permit system for storm watex runoff, which will require a permit for storm water discharges from point sources; and

c. Spill Prevention Control and Countermeasure (SPCC) Plan.

2. Sanitary Sewer Regulations are based on Federal pretreatment standards and promulgated by the City of Albuquerque.

3. Wastewater discharge regulations are administered by the NMEID.

4. Groundwater monitoring regulations of RCRA are also administered by the NMEID. 


\section{Solid Waste}

1. The Federal Comprehensive Environmental Response, Compensation, and Liability Act (CERCLA) regulates inactive waste sites and contains requirements for reporting hazardous material. spills to the National Response Center (NRC).

2. The RCRA regulates generation, storage, treatment, recycling, transport, and disposal of hazardous and nonhazardous solid waste.

a. Chemical hazardous waste is regulated by the RCRA.

b. USTs for hazardous substances are regulated by the RCRA.

c. Documented waste minimization programs are required by the RCRA.

d. Land disposal restrictions are applied by the RCRA for an increasing number of chemical wastes.

e. Radioactive MW is dually regulated by the Atomic Energy Act and RCRA.

3. The New Mexico Hazardous Waste Act allows the NMEID to promulgate regulations equivalent to or more stringent than Federal regulations to manage RCRA hazardous waste. While SNL and DOE disagrees, the NMEID is expected to receive authority to regulate MW from the EPA in 1990.

4. The New Mexico Solid Waste Management Regulations are equivalent to RCRA regulations in governing hazardous waste.

5. The Toxic Substances Control Act (TSCA) regulates the manufacture, distribution, use, handling, and disposal of certain toxic chemicals, including PCBs.

Summary of the Status of Current Permits and Other Notifications

Table 3-1 1ists the current environmental permits issued to SNL, Albuquerque, and those that are in the process of being reviewed by various agencies. Besides these environmental permits, notifications were made to the City of Albuquerque regarding asbestos removal (NESHAP - Subpart $M$ ) and beryllium emission/relocation (NESHAP - Subpart C). Also, several projects were evaluated for applicability of NESHAP - Subpart $H$ to facilities in Area V. Sixty-five septic tanics were registered with the NMEID, as required by the State discharge regulations, on Mily 9, 1989. 


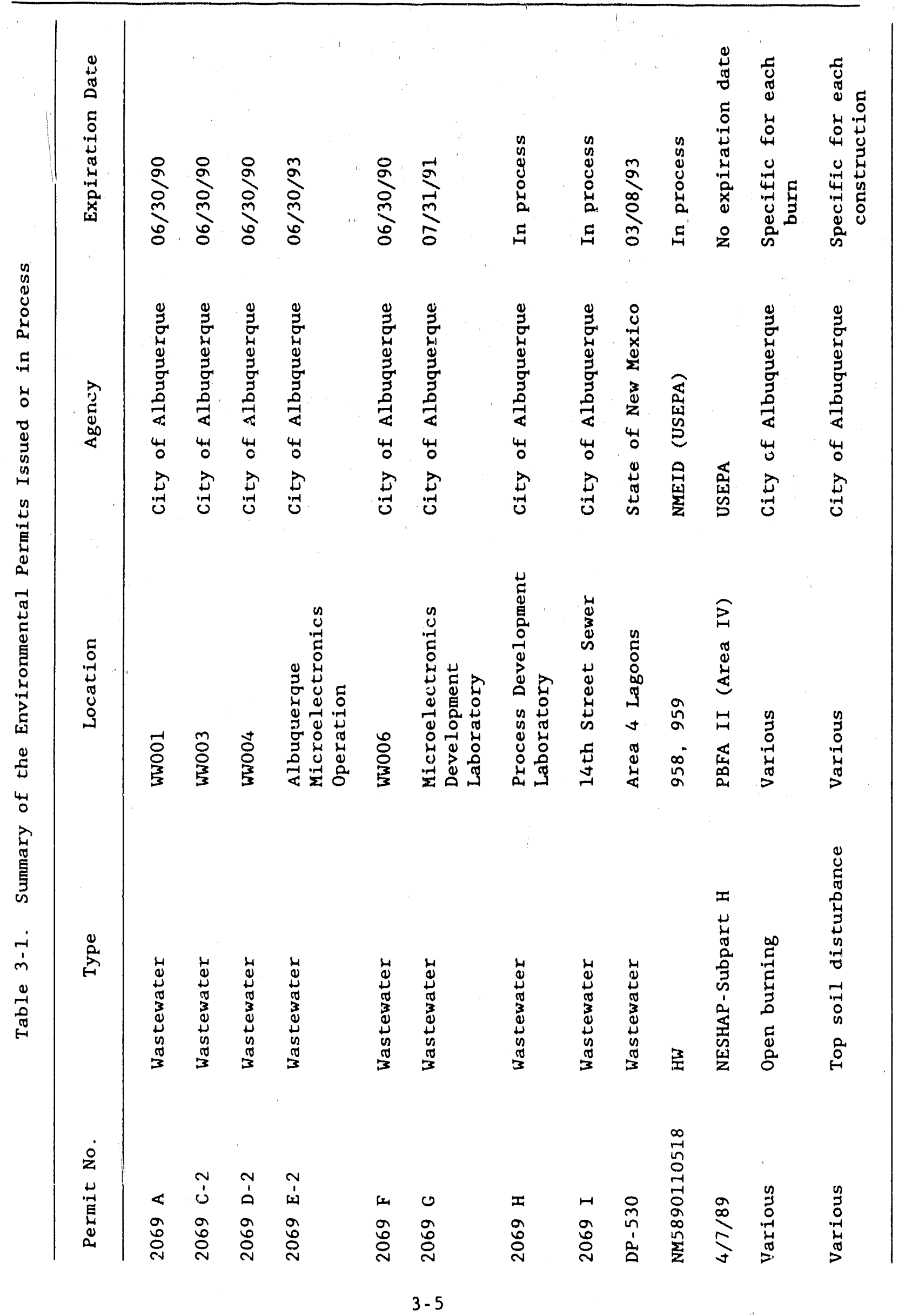




\subsection{Environmental Monitoring Programs}

The Environmental Monitoring and Compliance Program at SNL, Albuquerque, is administered by the Environmental Programs Department 3220 to ensure compliance with pertinent environmental regulations. The environmental monitoring program at SNL, Albuquerque, was begun in 1959. Its principal objective is to monitor radioactive effluents and associated environmental impacts resulting from SNL, Albuquerque, operations. The program has

expanded greatly to encompass nonradioactive effluents as well as hazardous and radioactive waste management and other environmental compliance activities. The growth of the program is in response to new environmental regulations as well as expanded SNL, Albuquerque, research programs.

The current environmental monitoring and compliance activities at SNL, Albuquerque, are described and documented in this report as required by DOE Order 5400.1, "General Environmental Protection Program." New programs which have been initiated within the last three years include a remedial action program (Section 4.1), a groundwater monitoring program (Chapter 7), a greatly expanded wastewater sampling program (Section 6.1), a UST removal program (Section 4.2.1), and an improved spill prevention program (Section 4.2).

The radiological monitoring programs which consist of environmental sirveillance on soll, vegetation, surface water, and well water and external radiation measurements by TLDs are summarized in Chapter 5 . The sampling locations are reviewed and modified, if necessary, each year to reflect any operational changes.

The nonradiological monitoring programs including those for wastewater monitoring, groundwater monitoring, and selected air quality monitoring are summarized in Chapters 6 and 7. These nonradiological monitoring results were submitted to regulatory agencies (e.g., State of New Mexico or City of Albuquerque) according to the regulations and permit requirements.

\subsection{Summary of 1989 Release Reporting}

\section{Reporting Requirements}

There are three types of release reporting requirements: (1) Reportable Quantity ( $R Q$ ) release reporting, (2) the Radioctive Effluent Information System/Onsite Discharge Information System (EIS/ODIS) Annual Report, and (3) the NESHAP for Radionuclides (Subpart H) Annual Report.

\section{RQ Reporting}

RQ reporting is regulated by CERCLA and Superfund Amendment and Reauthorization Act (SARA) Title III. It requires that any release to the environment in any $24-\mathrm{hr}$ period of any pollute it or hazardous substance in a quantity that was equal to or greater than the RQ in any $24-\mathrm{hr}$ period 
must be reported to the NRC immediately. However, if the release is "Federally permitted" under CERCLA Section 101(10)(H), it is exempted from CERCLA reporting. This reporting exemption also applied to any Federally permitted release under SARA Title III.

The Annual Summary of 1989 RQ Release Reporting for SNL, Albuquerque, is listed in Table 3-2. Most of the release was caused by the use of a NIKE rocket motor, which contains lead acetate as part of the propellant in sled track tests. These tests were conducted under the approval of an ADM dated June $5,1986$.

\section{EIS/ODIS Reporting}

DOE Order 5400.1 requires that the radioactive effluent and onsite discharge data covering the previous year for all planned and unplanned releases must be reported to the Waste Information System Branch, Edgerton, Germeshausen, \& Grier Corp. (EG\&G) Idaho, Inc., by April 1 each year.

The EIS/ODIS report for 1989 was submitted to the Waste Information System Branch, EG\&G Idaho, Inc., on March 30, 1990, It covered all the routine effluent releases (gas and liquid) from SNL, Albuquerque, operations. The

Table 3-2. Annual Summary of 1989 Reportable Quality (RQ) Release Reporting

\begin{tabular}{|c|c|c|c|c|c|c|c|}
\hline Date & Location & Material & Quantity & $\mathrm{RQ}$ & $\begin{array}{c}\text { Release } \\
\text { To }\end{array}$ & $\begin{array}{c}\text { NRC } \\
\text { Number }\end{array}$ & $\begin{array}{c}\text { Report } \\
\text { Date }\end{array}$ \\
\hline $12 / 13 / 88$ & $\mathrm{TA}-\mathrm{III}$ & Lead 1 & $3.73 \mathrm{Ib}$ & $11 \mathrm{~b}$ & Air & 00248 & $01 / 06 / 89$ \\
\hline $02 / 01 / 89$ & $\mathrm{TA}-\mathrm{III}$ & Lead 1 & $3.73 \mathrm{lb}$ & $11 \mathrm{~b}$ & Air & 01570 & $02 / 02 / 89$ \\
\hline $02 / 02 / 89$ & TA-III & Lead 1 . & $3.73 \mathrm{lb}$ & $1 \mathrm{lb}$ & Air & 01571 & $02 / 02 / 89$ \\
\hline $03 / 23 / 89$ & TA-III & Lead 1 & $3.73 \mathrm{lb}$ & $11 b$ & Air & 04167 & $03 / 23 / 89$ \\
\hline $07 / 28 / 89$ & TA-III & Lead 1 & $3.73 \mathrm{lb}$ & $11 \mathrm{~b}$ & Air & 13046 & $07 / 31 / 89$ \\
\hline $08 / 28 / 89$ & TA-II & Asbestos ${ }^{2}$ & $1 \mathrm{lb}$ & $11 \mathrm{~b}$ & Ground & 15214 & $08 / 28 / 89$ \\
\hline \multicolumn{8}{|c|}{$\begin{array}{l}\text { 1 Lead release from NIKE rocket motor-sled track test. } \\
2 \text { Asbestos was found from the insulation material stripped off from a pipe } \\
\text { by a contractor. }\end{array}$} \\
\hline
\end{tabular}


major radioactive air releases were from the Area $V$ reactors (ACRR and SPR). For 1989, SNL, Albuquerque, released a total of $8.8 \mathrm{Ci}$ of $41_{\mathrm{Ar}}$, $0.6 \mathrm{Ci}$ of $133 \mathrm{Xe}$ with some $85 \mathrm{Kr}$, approximately $0.2 \mathrm{CI}$ each of $13 \mathrm{~N}$ and 150 , and a $\mu \mathrm{Ci}$ range of $3_{\mathrm{H}}$ and depleted uranium. The limited liquid waste discharges from ACRR were in micro-Ci ranges of $24 \mathrm{Na}, 51_{\mathrm{Cr}}, 58 \mathrm{Co}$, and other fission products. All of these releases were within regulatory recommended limits.

\section{NESHAP Reporting}

NESHAP in 40 CFR Part 61 Subpart: $H$ for radionuclides requires that an Annual Report from each DOE site must be submitted to EPA by June 1 each year. The report should include the calculated maximum offsite dose impacts (whole-body dose equivalent and critical organ dose) to the public and the associated input data for this calculation (40 CFR 61.94(c)).

Although the NESHAP for radionuclides have been revised and the new standards promulgated on December 15, 1989, the report required under 40 CFR 61.94 for calendar year 1989 was still to be made in accordance with the old standards. The new requirements under the revised section of 40 CFR 61.94 for the more extended annual reporting will take effect calendar year 1990 .

The dose assessment for the public due to SNL, Albuquerque, operations in 1989 is discussed in detail in Section 5.3.

\section{Environmental Incident Form}

A Sandia Environmental Incident Form (Appendix $\mathrm{H}, \mathrm{Table} \mathrm{H-4)}$ was designed to gather information regarding any unplanned releases of hazardous or radioactive material. The implementation of this internal reporting will be initiated in calendar year 1990. This form consists of Part I (seven items) and Part II (seven items) that describe detailed release information and corrective actions. All reportable and nonreportable releases will be included to ensure proper follow-up actions were taken and to prevent their recurrences. 


\section{CHAPTER 4}

\section{OTHER ENVIRONMENTAL COMPLIANCE PROGRAMS}

\subsection{Environmental Restoration (ER) Program}

The ER Program is a phased DOE program to identify, assess, and correct past spill, release, or disposal sites at all DOE/AL facilities including SNL, Albuquerque. The initial identification of sites at the Albuquerque location was completed in 1987. The Installation Assessment Report identified, 117 sites that would require further evaluation (DOE/AL, 1987). After completion of the Installation Assessment, additional sites have been identified, and the total number of potential release sites at Albuquerque now totals 135 . The majority of the new sites identified were septic tanks and drainfields that may have received nondomestic wastes. It is anticipated that a few additional sites may be identified in the future.

The individual potential release sites identified in the Installation Assessment and subsequent evaluations are grouped together within geographic and event-related boundaries. These groups of release sites are called "tasks" for budget development and program tracking purposes. Table B-1 identifies the specific potential release sites that are assigned within an individual task. Figure 4-1 shows a map with the approximate locations of the groups of sites assigned within each task.

The grouping of potential release sites will allow the assessment investigations to collect samples efficiently and cost effectively. The geographically derived groups will also provide an opportunity to collect installation generic data on a regional basis during a single sampling campaign.

The assessment and remediation of potential release sites identified by the ER Program will be monitored by the NMEID as a requirement of the RCRA waste management operating permit. The authority for this permit provision is from the RCRA $3004(u)$ requirement for the corrective action of all releases from all Solid Waste Management Units (SWMUs) located at the facility that are seeking a RCRA waste management operating permit. Since the permit is expected to be issued in 1991, the ER Program began utilizing the guidance for RCRA Corrective Action evaluations in 1989. During 1989, assessment efforts continued on one task: MWL AL-SA-RC-2. Three groundwater monitoring wells were installed to supplement one that was installed in 1988. The locations of the wells are shown in Chapter 7 . In addition, a stage one assessment investigation into the potential releases from the MWL was initiated. 


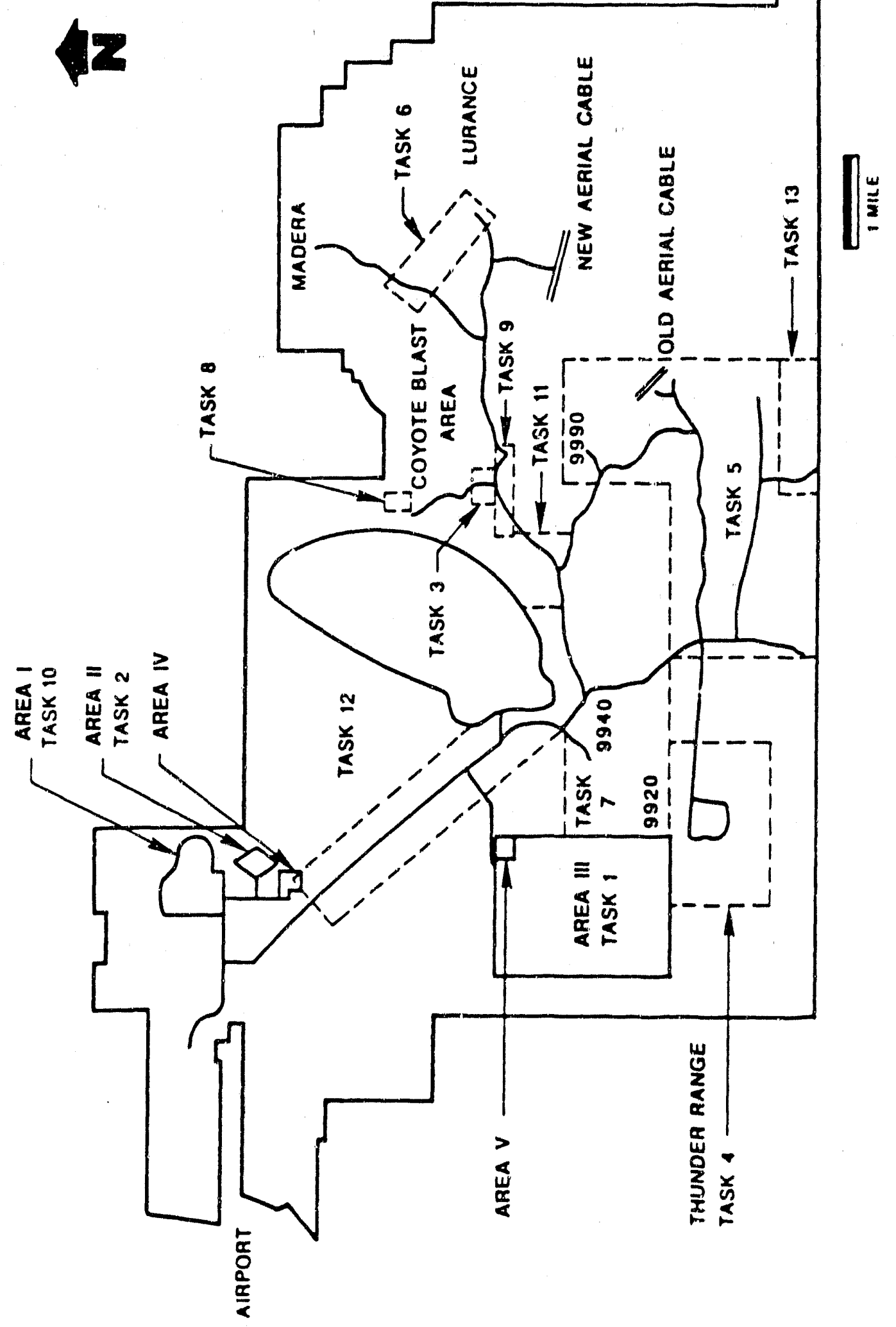

焉 


\subsection{Underground Storage Tanks (UST) Management and Spil1 Prevention Control Plan}

\subsubsection{Underground Storage Tanks (USTs)}

USTs at SNL, Albuquerque, are managed in accordance with the state of New Mexico UST Regulations. The New Mexico UST Regulations have been written to comply with the requirements of 40 CFR Part 281 - Approval of State UST Programs.

Eight USTs were permanently closed by removal in 1989. The NMEID was notified in writing at least 30 days in advance of each removal. The NMEID was also notified by telephone 24 to $48 \mathrm{hr}$ in advance of each renoval. The removed USTs are 1 isted in Appendix $H$, Table H-1. Every UST and excavation was inspected for evidence of release. No releases were determined to have occurred, and the NMEID was notified of this in writing for each UST closure.

Fifty-two USTs were registered at the end of 1989, including four that were previously unregistered. The registered USTs are listed in Appendix $H$, Table H-2. A draft Tank Management Plan was also developed in 1989. The plan will be finalized in 1990. The elements of the plan include a tank inventory; a UST upgrade prioritization schedule; and more detailed procedures for inventory control, leak detection, removal, and installation.

\subsubsection{Sp111 Prevention Control Plan (SPCC)}

Oil spill control activities at SNL, Albuquerque, are coordinated by the SPCC Plan. This plan was prepared in accordance with 40 CFR 112. According to these regulations, the plan must be reviewed and evaluated every three years. The current plan was approved in July 1987. The review and evaluation activity began in December 1989 and is scheduled for completion in June 1990. Construction activities for 1989 include the construction of secondary containment at the tank truck loading and unloading area in Technical Area $I$, the purchase and distribution of spill control pallets, the construction of secondary containment for drum storage at the motorpool, and the design of the secondary containment for the fuel storage tanks at the Burn Site.

\subsection{Waste Management Programs}

\subsubsection{Mixed Waste Compliance Programs}

SNL, Albuquerque, has recently submitted a Part A Permit Application for MW storage and treatment to DOE/AL for signature and submittal by DOE/AL to the State of New Mexico. Also, programs are currently being developed to meet the characterization requirements of the following regulations: RCRA Part 261 and Part 265 for MW storage, RCRA Part 268 restrictions on land disposal, DOE Order 5820.2A, and NVO-325 waste acceptance criteria for proper disposition of defense LLW and MW at the NTS. Transuranic (TRU) 
(including mixed TRU) waste packaging and certification procedures are being developed to meet the Waste Isolation Pilot Program Waste Acceptance Criteria (WIPP WAC).

\subsubsection{Radioactive Waste}

Onsite disposal of LLW was terminated in December 1988 at SNL, Albuquerque, by order of the DOE. Presently, all LLW and MW are being temporarily stored at generator sites or above ground in transport containers at the inactive Area III Disposal Site. Approximately 2,000 $\mathrm{ft}^{3}$ of waste were accepted at the Area III storage location in 1989. The waste consisted primarily of fission product and uranium contaminated waste.

Construction of the RMWMF was begun in 1989. This 6,000-sq ft facility will serve as a centralized storage facility for generated $L L W$ and $M W$ at SNL, Albuquerque. Draft applications were prepared in 1989 for the offsite disposal of LLW and MW at the NTS.

Ultimately, the TRU waste generated at SNL, Albuquerque, will be disposed of at the WIPP. Currently, all generated TRU waste is packaged and stored at generator-controlled locations.

\subsubsection{Special Case Waste}

SNL, Albuquerque, will perform a site-wide inventory of six categories of special-case $(\mathrm{SC})$ waste:

- DOE comparable greater-than-Class-C (SC-GTCC)

- Performance assessment limiting (SC-PAL)

- Uncertifled or uncharacterized (SC-US)

- Noncertifiable, nontransportable TRU (SC-TRU)

- High-level incidental waste (SC-HLI)

- Commercially held, DOE-owned materials (SC-COM)

The scope of this identification and characterization effort is significantly larger than previous efforts to identify similar types of wastes, which consisted mainly of identifying SC-GTCC wastes. The current scope includes existing and potential wastes in the six SC waste categories above and will provide information necessary for EPA permits. Potential waste is included because these wastes must be disposed of in the short. term future and may require development of special management and disposal strategies. Potential SC waste includes materials which are not now waste but may be declared waste (and meet the special-case criteria) in the future. Information on potential waste will be used to assist in long-term management planning.

4.3.4 Hazardous Waste and the Resource Conservation and Recovery Act (RCRA)

All RCRA regulated wastes generated by SNL, Albuquerque, are transported offsite for disposal at EPA-permitted Treatment Storage and Disposal 
Facilities (TSDFs). The CWL located in Technical Area III was used for onsite disposal from 1962 through November 1985. A RCRA Closure Plan for the facility was submitted to the NMEID in May 1988. Negotiations with the NMEID on the closure continued during 1989. This landfill is no longer used for disposal of hazardous chemicals.

Chemical wastes generated by SNL, Albuquerque, research and development (R\&D) activities are collected from generator locations, segregated according to Department of Transportation (DOT) hazard class, and transported to the Hazardous Waste Management Facility (HWMF) for storage. Packaged wastes are transported by EPA-permitted carriers to EPA-permitted TSDFs for disposal.

The EPA-permitted commercial transporters used to transport SNL hazardous waste during 1989 are listed in Table 4-1. The permitted TSDFs used for disposal of SNL hazardous wastes are listed in Table 4-2 along with the waste triatinent methods employed at each facility.

During calendar year 1989, $179,098 \mathrm{~kg}$ of chemical wastes were managed by SNL's hazardous waste management program, including $127,946 \mathrm{~kg}$ of RCRA regulated hazardous waste and $51,152 \mathrm{~kg}$ of nonregulated industrial wastes. A total of 48,899 packages were collected from SNL generators in calendar year 1989, put into 4,664 containers, and sent to TSDFs in 43 shipments. The increase of approximately $20,000 \mathrm{~kg}$ over the volume of chemical waste managed in calendar year 1988 was partially the result of a laboratorywide Environment, Safety and Health (ES\&H) initiative conducted at SNL, Albuquerque, during the last five months of calendar year 1989. As part of the ES\&H initiative, an "Orphan Chemical" Program was conducted to identify any improperly stored and labeled chemicals stored outside at SNL, Albuquerque.

In calendar year 1989, a covered waste oll storage area was built on the HWMF grounds to provide covered, bermed storage of waste ofl and storage for HWMF supplies. A containment pond to hold runoff and fire-fighting water from the HWMF was completed in late 1989.

\section{Permitting Activities}

In 1989, NMEID conducted an informal hearing on the RCRA Permit $B$ application by SNL, Albuquerque, with staff from EPA Region VI participating. The informal hearing was an opportunity for interested Albuquerque citizens to ask questions about and make comments on the permit application.

\subsubsection{Waste Minimization and Pollution Prevention Awareness}

A waste minimization and pollution prevention awareness program was initiated in 1989 to comply with both EPA regulations and DOE Order 5820.2A. It will address hazardous, mixed, and radioactive wastes. 
Table 4-1. SNL, Albuquerque, Hazardous Waste Transporters ${ }^{*}$ Used in CY89

1. ENSCO, INC.

2. Hazmat Environmental Group, Inc.

3. Rinchem Company, Inc.

4. Safety-Kleen Corp.

5. Star Motor Freight Lines, Inc.

6. Delta Environmental

7. Custom Environmental Transport

*Identification of these companies is not necessarily an endorsement of their services by SNL, Albuquerque.

Table 4-2. SNL, Albuquerque, Waste Disposal Facllities* Used in CY89

Treatment

1. BDT, Inc.

2. Chemical Waste Management, Inc.

3. Conservation Services, Inc.

4. ENSCO, Inc.

5. Hydrocarbon Recyclers, Inc.

6. Rollins Env Sves, Inc. (TX)

7. Rollins Env Sves, Inc. (IA)

8. Safety Kleen Corp.

9. USPCI (Grassy Mt., VT)
- Hydrolysis of Reactive Metals

- Encapsulation, Landfill

- Non-RCRA Waste Landfill

- Incineration

- Recycling

- Incineration

- Incineration

- Recycling

- Treatment, Encapsulation, Landfill

*Identification of these companies is not necessarily an endorsement of their services by SNL. 
The diversity of the wastes and the large number of small amounts of different chemical types make source reduction difficult in many situations. Waste reduction efforts to date, therefore, have focused primarily on finding means to reclaim or reuse generated wastes using offsite technology.

Recycling and reapplication efforts will continue, with an increased emphasis on source reduction via process modifications, substitution of nonhazardous and nonradioactive materials for hazardous and radioactive materials, and segregation of hazardous and radioactive materials to avoid generation of MW.

In 1989, an analysis was commissioned to study minimizing onsite recycling of used ofl and solvents. The analysis indicated that a 41 percent reduction of hazardous waste and an annual savings of greater than $\$ 50,000$ could be accomplished, if implemented. The implementation will require a detailed evaluation of specific waste streams. Pending on the budget and staffing level, this evaluation will be carried out as soon as possible.

In addition, several specific HW minimization activities were carried out in 1989:

A. $166,800 \mathrm{~kg}$ of potassium nitrate used in solar heat-transfer experiments were shipped to a metal finishing plant for reuse. These salts would otherwise have been disposed of as RCRAregulated waste.

B. $3,000 \mathrm{~kg}$ of (glycol containing) aqueous foam were donated to Albuquerque Fire Fighter Academy for use in training firefighters.

C. $450 \mathrm{~kg}$ of $\mathrm{n}$-butyl acetate were reused as a paint thinner,

D. $250 \mathrm{~kg}$ of sodium were converted into sodium hydroxide and used as a neutralizer of acids.

E. $250 \mathrm{~kg}$ of $\mathrm{Hg}$-containing switches were reapplied.

F. $250 \mathrm{~kg}$ of mercury were recycled.

G. A Chemical Exchange Program was initiated at SNL, Albuquerque, during the latter part of calendar year 1989. The program resulted in the reuse of 729 containers of unused, unexpired excess chemicals which would otherwise have been disposed of as hazardous waste. This reuse resulted in an estimated savings to SNL, Albuquerque, of $\$ 11,161$.

H. An aqueous processing line is being installed in the new printed circuit facility to eliminate the use of chlorinated solvents. 
I. An acid and base neutralization unit was installed in the HWMF. Approximately 22 percent of the hazardous wastes at SNL, Albuquerque, are acids and bases.

$\mathrm{J}$. Solvent recycling/reuse during calendar year 1989 resulted in the recycling of $49,330 \mathrm{~kg}$ of solvents that would otherwise have been disposed of at a higher cost.

$K$. Other recycling/reuse initiatives resulted in a minimization of approximately $9,500 \mathrm{~kg}$ of chemical waste.

Radioactive waste minimization practices have included reviews of experi. ment and facility design to avoid generating radioactive waste or MW whenever possible. Generators are provided with guidance to prevent generating $M W$ by materials substitution and segregation of radiation from hazardous materials. Examples of radioactive waste and MW minimization include the following:

A. Use of a nonhazardous liquid scintillation cocktail solution helped minimize radioactive waste production.

B. A review of the SDF, ECF, and RMWMF design prevented commingling of radioactive and nonradioactive waste streams and minimized the generation of liquid waste streams.

C. Separate LLW and MW compactors have been purchased for the RMWMF.

D. Disposable articles in the contaminated areas in Area IV have been replaced with anticontamination clothing consisting of rubber gloves and boots that are monitored and released after use.

E. Paper floor coverings in the same areas as above have been replaced with an extremely durable material produced by Herculite F'roducts, Inc. This material is fire retardant, tear resistant, long lasting, and easy to decontaminate.

F. A Radioactive Materials Area has been established in Area IV to allow personnel to work on radioactive material after removing loose contamination without the use of protective clothing.

G. Refurbishment of the PBFA II stacks has been coordinated to survey and release components after wipe down prior to subsequent oiling to preclude the production of radioactive oily wastes.

H. A HEPA-filtered glove box and tent has been purchased to facilitate grinding and machining of radioactive parts in Area IV, eliminating the need for transport of material to Area II. 
The previously used scintillation cocktails were considered MW. The current one can be disposed of in the sanitary sewer. The substitution has reduced $\mathrm{MW}$ generation by over $15 \mathrm{~kg} / \mathrm{yr}$.

\subsubsection{Polychlorinated Biphenyl (PCB) Waste}

SNL, Albuquerque, is in the process of phasing out PCB and PCB-contaminated/ equipment to the greatest extent possible. For example, all electrica? distribution equipment at the laboratory is either being replaced ar retrofitted. It is expected that all such equipment will contain less than a 50-ppm PCB concentration by January 1991. For non-distribution electrical devices and other equipment, an expanded PCB survey is currently being conducted to identify PCB-containing items. In 1989, over 400 items, including research electrical devices, vacuum pumps, and hydraulic equipment, were sampled for PCB content. Most contained no detectable amounts of PCBs.

All items containing any concentration of $\mathrm{PCBs}$ are documented and controlled by SNL, Albuquerque, and will be replaced and disposed of as soon as practical. 


\section{CHAPTER 5 \\ RADIOLOGICAL MONITORING}

SNL, Albuquerque, has maintained an environmental radiological monitoring program since February 1959 (Burnett et al., 1961; Brewer, 1973; 1974; Holley, 1975; Holley and Simmons, 1976; Simmons, 1977; 1978; 1979; 1980; Millard, 1981; Millard et al., 1982; 1983; 1984; 1985; 1986; 1987; 1988; 1989). The objectives of this surveillance program are to detect the release and/or migration of radioactive material from SNL, Albuquerque, operations and to determine the resulting population exposures above normal background radiation levels. The radiological monitoring program also provides a check on the effectiveness of reactor radiological safety systems that are in effect at Area $V$. Radioactive effluent discharges to the environment will be kept at ALARA levels and in accordance with DOE Order 5400.5 for environmental protection. Soll, vegetation, and water are monitored for radionuclides, primarily $137_{\mathrm{Cs}}$ and $3_{\mathrm{H}}$. Gross $\alpha$ and $\beta$ screening analysis are performed on water samples. Soil samples are analyzed for uranium.

In addition to the above elements of the radiological surveillance, a program was begun in 1981 which uses TLDs to measure ambient levels of external penetrating radiation around each major facility. Before a facility's contribution to a population dose can be calculated (in the event of an unplanned release), a good estimate of ambient background with its inherent variability must be available. Natural background radiation levels are affected by many environmental factors, including ground cover and seasonal variations in precipitation and temperature.

\subsection{Radioactive Effluent Monitoring}

There are few facilities within SNL, Albuquerque, that routinely generate radioactive effluents or emissions. These facilities include the accelerators in Technical Area IV (e.g., HERMES-III and PBFA-II), the reactors in Technical Area V (e.g., ACRR and SPR), and the Neutron Generator Test Facility in Technical Area II. Most of these are air emissions. A small quantity of radioactivity is released as liquid effluent from the ACRR Reactor cooling tank.

Small quantities of ${ }^{3} \mathrm{H},{ }^{41} \mathrm{Ar},{ }^{85} \mathrm{Kr}$ and $133 \mathrm{Xe}$ emissions have been released to the atmosphere as a result of SNL, Albuquerque, operations. Because SNL's air emissions are so small, they are not measurable, and the release data are calculated based on theoretical parameters such as reactor operating power (in $\mathrm{MJ}^{\prime} \mathrm{s}$ ) and the conversion factor for the activation products (in $\mathrm{uCi} / \mathrm{MJ}$ ) for the generation of noble gases (e.g., $41_{\mathrm{Ar}}$ ) from the reactors in Technical Area $V$. Figure 5-1 summarizes these annual air emissions from 1975 to 1989. 


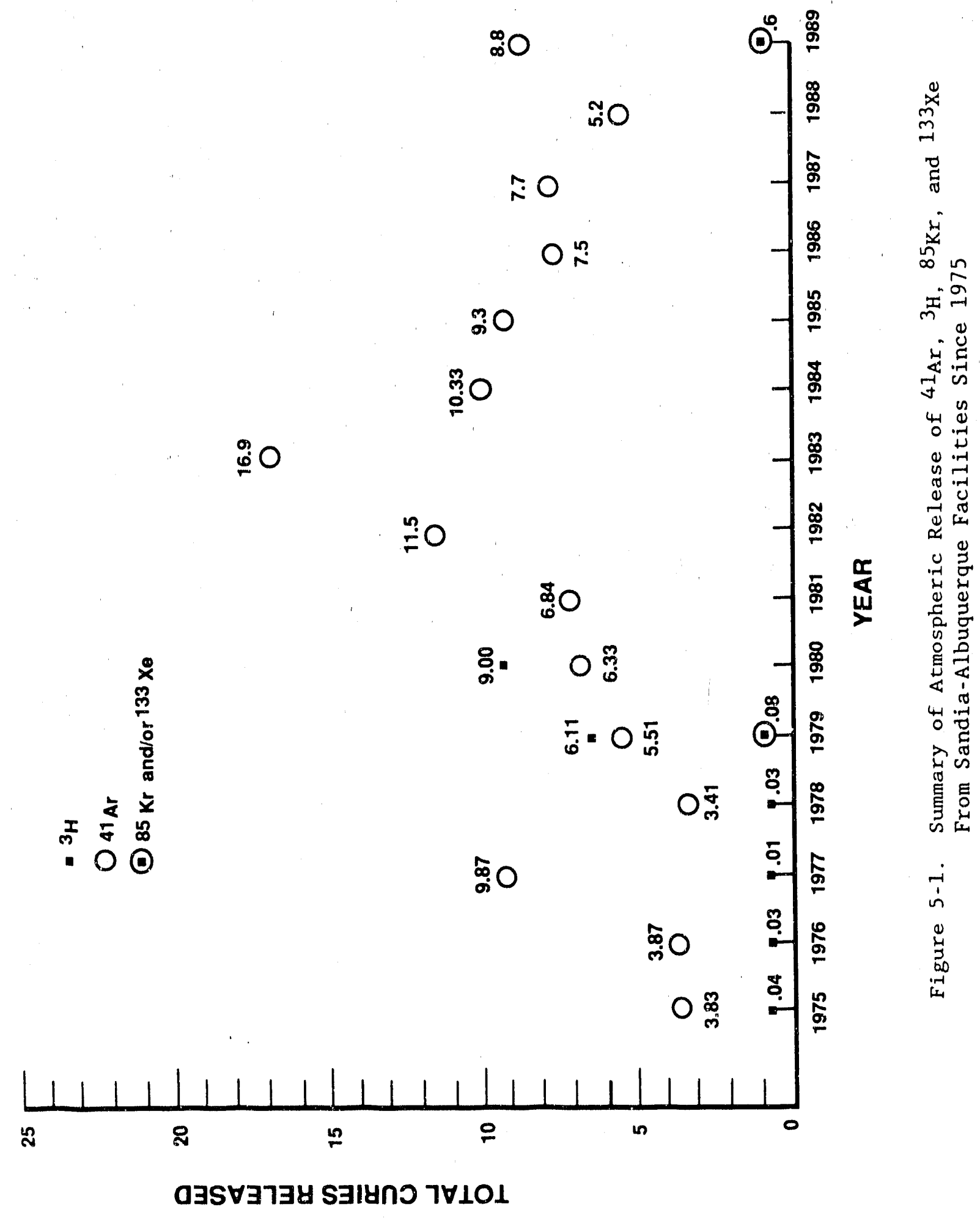




\section{Technical Area V Reactors}

Only noble gases are released from Area $V$ reactor stacks. HEPA filters are used to filter out particulates from SPR, ACRR, and Hot Cell exhaust air. Charcoal filters are used to collect noble gases from the SPR and ACRR stach exhaust air. Gamma scans are performed on the filters to check for activity. Particulate or gaseous grab samples are collected periodically or as necessary for specific radionuclide analyses. These results were used as a confirmatory measure to verify the calculated values by theory.

The SPR reactor filter banks consist of a prefilter, HEPA filter, and charcoal filter. A radiological air monitor (RAM) is located on the stack exhaust downstream of the filter banks. Grab samples are collected periodically using a low volume particulate air filter which is analyzed for gamma-emitting particulates using a multi-channel analyzer (MCA).

The ACRR reactor filter banks also consist of a prefilter, HEPA filter, and charcoal filter. ACRR has two exhaust stacks. The main room stack in the high bay is equipped with two continous air monitors (CAMs), a particulate and a gaseous air monitor, as well as a RAM which is located on the HEPA filter housing. Gamma-beta scans are performed on the filters to determine the gross activity. Particulate or gaseous grab samples are also collected, if necessary, for more detailed analysis (i.e., ${ }^{41} \mathrm{Ar}$ ) with a MCA. The second ACRR exhaust stack, the central cavity purge stack, has a particulate CAM as well as a RAM which is located directly on the HEPA filter housing. Grab samples for MCA analysis can also be collected.

The Area V Hot Cell Facility filter banks are equipped with a prefilter and HEPA filter. RAMs are located on the filter banks on both the cold exhaust and hot exhaust. Grab samples for particulates can also be collected, if needed, for further analyses. These results have been used for evaluation of the exhaust filtration system.

In 1989, two sets of isokinetic sampling equipment were purchased. One was installed within the main stack of the Hot Cell Facility to collect air samples; the other one will be installed in the ACRR stack. Both of these air samplers will become operational in 1990. Therefore, routine effluent sampling and analyses will be performed and reported in future environmental monitoring reports.

\subsection{Environmental Sampling and Surveillance}

\section{Monitoring Locations}

The SNL, Albuquerque, environmental surveillance locations (Figures 5-2 and 5-3) remain essentially the same from year to year. The selection of these sampling locations was based on all potential releases, past contamination areas, and other potential impacts to the offsite residents and the surrounding environment. Monitoring locations are changed as necessary to 


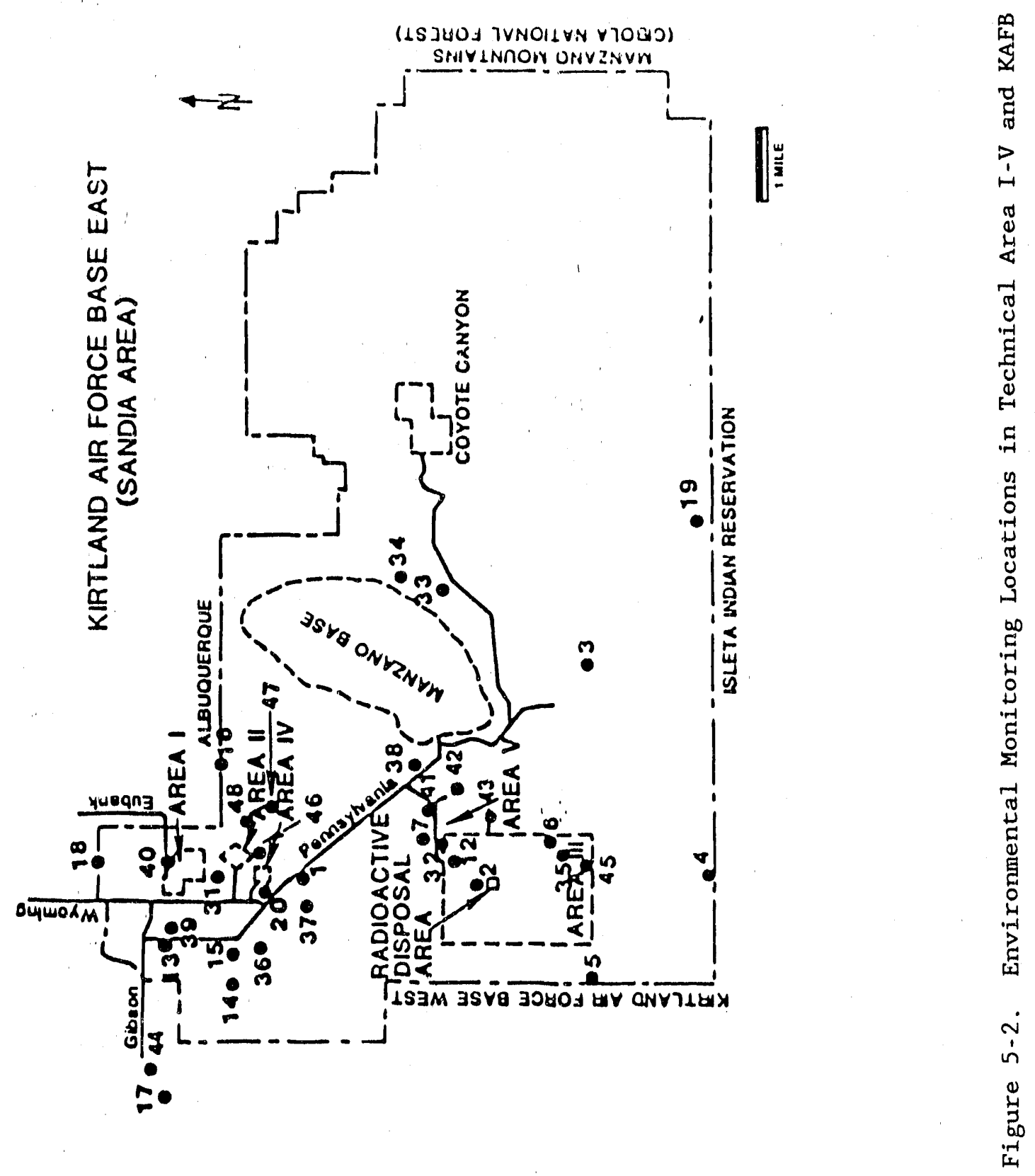




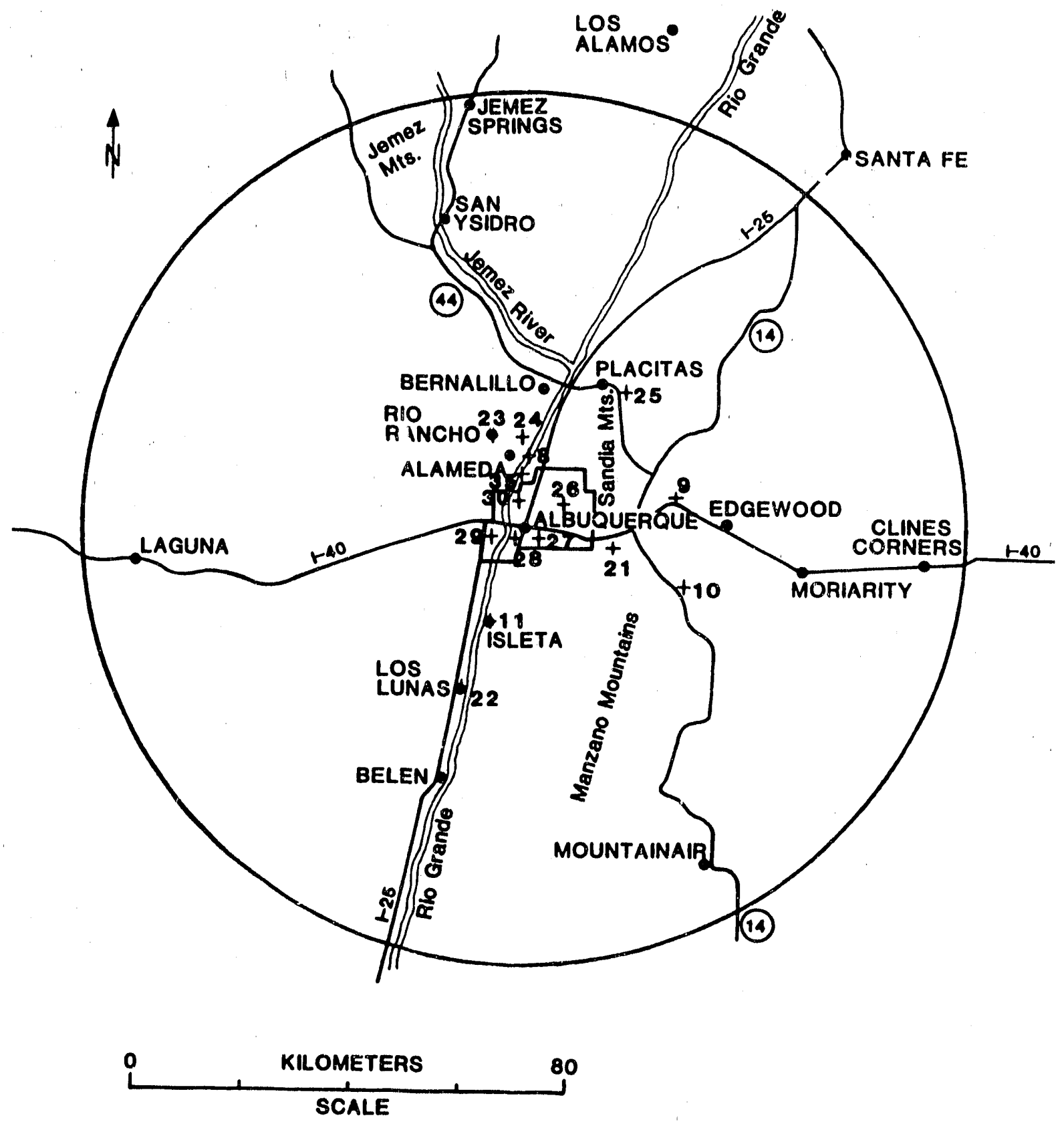

Figure 5-3. Community Monitoring Locations in the Albuquerque Area 
accommodate facility changes. Three new TLD locations were added in 1987. They were located at the north, east, and south radiation control fence lines surrounding Area $V$. Additional TLD stations were placed in Area IV in 1988 to monitor radiation levels at new facilities. Groundwater samples for radiological analysis are collected from base wells in use at the time of sample collection, and the sampled wells may differ from one year to the next.

Table 5-1 lists the SNL, Albuquerque, environmental monitoring locations and specifios the type of sample collected (vegetation, water, soil) or the presence of a TLD station for each location. There are a total of 52 sampling locations (Table 5-1). Thirty-one locations (labelled as $S$ ) are onsite at SNL, Albuquerque; seven are on KAFB boundaries (labelled as $P$ ), and 14 are community or background sites (labelled as C) distributed in and around Albuquerque within an $80-\mathrm{km}$ radius of SNL, Albuquerque. Water monitoring locations include nine KAFB wells and three surface water locations.

Location 8 is a surface water sampling location on the Rio Grande River upstream of the SNL, Albuquerque, facilities. It provides control data for comparison with Location 11, a downstream Rio Grande sampling location. Location 49, near the proposed ECF is a new sampling site designed to monitor the background before the operation of the ECF site. TLD Station 32 was eliminated in October 1989, because it was inside the Area $V$ radiation control fence (at the east corner of the SPR security fence) and does not serve the purpose of environmental monitoring for that area.

\section{Sample Collection and Analysis}

Samples are gathered and stored in accordance with methods described in USDOE/EP-0023 (DOE, 1981). These procedures have been dosumented in an Environmental Monitoring Manual (SNL, Albuquerque, 1986). Native vegetation (mostly grasses), soil, and water samples are collected annually at the end of the growing season. These procedures are described in Appendix C. Detection Limits for each type of radio-chemizal analysis are included in Appendix D.

A total of 82 samples was submitted for tritium and gamma spectrometry analysis in 1989. Fifty-two samples were analyzed for uraniun. Seventysix water and filter samples were screened for gross $\alpha$ and $\beta$. Sampling frequencies are summarized in Table C-1.

\section{Monitoring Results}

Appendix F lists the monitoring results for all sample locations. Calculated summary data tables are included and discussed in the following paragraphs. MDL values were set equal to the MDL in the calculation of mean $(\bar{x})$ values. 
Table 5-1. SNL. Albuquerque Environoentel Honitoring Locations and Smple Typer for Radioactive Survelliance

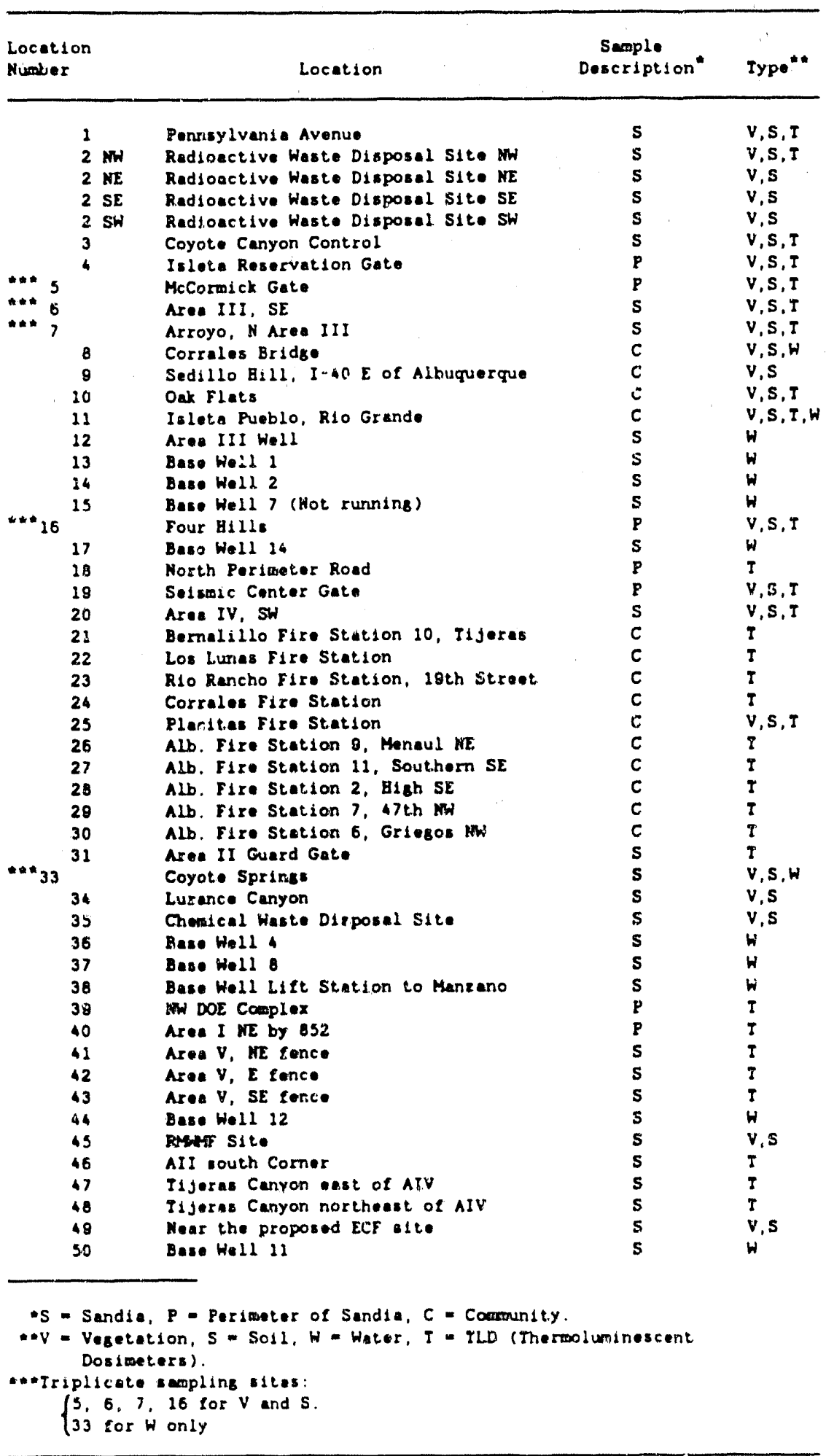




\section{Vegetation}

Table F-1 gives concentrations of ${ }^{3} \mathrm{H}, 137 \mathrm{Cs}$, and $40_{\mathrm{K}}$ in vegetation (primarily grass species) for $18 \mathrm{SNL}$, eight perimeter, and five community samples. Table 5.2 compares the mean concentrations and respective standard deviations, as well as ranges, for ${ }^{3} \mathrm{H}$ and $137 \mathrm{Cs}$ in vegetation for the three types of sampling locations. The $137 \mathrm{Cs}$ concentrations ranged from $\angle M D L$ values to $0.18 \mathrm{pCi} / \mathrm{g}$. Eighteen samples had above MDL $137 \mathrm{Cs}$. Tritium concentrations, reported as $\mathrm{pCi}$ per $\mathrm{ml}$ of extracted water, ranged from $\angle M D L$ to $16.5 \mathrm{pCi} / \mathrm{ml}$. The reported $137 \mathrm{Cs}$ concentrations (Table 5-2) are consistent with fallout levels. The $137 \mathrm{Cs}$ concentrations at the three locations were not significantly different. The reported ${ }^{\mathrm{H}}$ concentrations fall within the range of background ${ }^{3} \mathrm{H}$ levels for this area, except Station 2 (NE) at the inactive radioactive waste disposal site and Station 33 at coyote spring. These two locations have historically shown higher than background values.

Tabie 5-2. Mean Concentrations of ${ }^{3} \mathrm{H}$ and $137 \mathrm{Cs}$ in Vegetation

\begin{tabular}{|c|c|c|c|c|c|}
\hline \multirow[b]{2}{*}{ Nuclide } & \multirow[b]{2}{*}{ Location } & \multirow[b]{2}{*}{ Sample Size } & \multicolumn{3}{|c|}{ Concentration } \\
\hline & & & $\begin{array}{l}\text { Mean } \\
(\bar{x})^{\star}\end{array}$ & $\begin{array}{c}\text { Standard } \\
\text { Deviation } \\
\text { (s) }\end{array}$ & Range \\
\hline \multirow[t]{2}{*}{$\begin{array}{l}{ }^{3} \mathrm{H} \\
(\mathrm{pCi} / \mathrm{ml})\end{array}$} & $\begin{array}{l}\text { Sandia } \\
\text { Perimeter } \\
\text { Community }\end{array}$ & $\begin{array}{r}18 \\
8 \\
5 \\
\end{array}$ & $\begin{array}{r}1.55 \\
0.61 \\
\leq 0.45 \\
\end{array}$ & $\begin{array}{l}3.78 \\
0.28 \\
* * \\
\end{array}$ & $\begin{array}{r}0.45 \text { to } 16.5 \\
0.45 \text { to } 1.1 \\
\leq 0.45\end{array}$ \\
\hline & Total & 31 & 1.08 & 2.89 & $<0.45$ to 16.5 \\
\hline \multirow[t]{2}{*}{$\begin{array}{l}137 \mathrm{Cs} \\
(\mathrm{pCi} / \mathrm{g})\end{array}$} & $\begin{array}{l}\text { Sandia } \\
\text { Perimeter } \\
\text { Community }\end{array}$ & $\begin{array}{r}18 \\
8 \\
5 \\
\end{array}$ & $\begin{array}{l}0.09 \\
0.06 \\
0.03 \\
\end{array}$ & $\begin{array}{l}0.09 \\
0.05 \\
0.01 \\
\end{array}$ & $\begin{array}{lll}<0.03 & \text { to } & 0.18 \\
<0.02 & \text { to } & 0.14 \\
\leq 0.02 & \text { to } & 0.03 \\
\end{array}$ \\
\hline & Total & 31 & 0.05 & 0.04 & $<0.02$ ro \\
\hline $\begin{array}{l}* 1.37 \mathrm{Cs}< \\
* * \mathrm{~s} \mathrm{no-}\end{array}$ & $\begin{array}{l}\text { values wer } \\
\text { ulated sir }\end{array}$ & $\begin{array}{l}\text { ed in calc } \\
\text { lost values }\end{array}$ & $\begin{array}{l}\text { ons of } \\
\text { less }\end{array}$ & han 0.45 . & \\
\hline
\end{tabular}

Soil

Concentrations of uranium and $137 \mathrm{Cs}$ and $3 \mathrm{H}$ in soil samples are reported in Table F-2 for 18 SNL, eight perimeter, and five community samples. Table 5-2 sumsarizes the sean concentrations, respective standard deviations, and 
Table 5-3. Mean Concentrations of Uranium, ${ }^{137} \mathrm{Cs}$, and $3_{\mathrm{H}}$ in Soil Samples

\begin{tabular}{|c|c|c|c|c|c|}
\hline \multirow[b]{2}{*}{ Nuclide } & \multirow[b]{2}{*}{ Location } & \multirow[b]{2}{*}{ Sample Size } & \multicolumn{3}{|c|}{ Concentration } \\
\hline & & & $\begin{array}{l}\text { Mean } \\
(\bar{x})\end{array}$ & $\begin{array}{c}\text { Standard } \\
\text { Deviation } \\
\text { (s) }\end{array}$ & Range \\
\hline \multirow[t]{2}{*}{$\begin{array}{l}\text { Uranium } \\
(\mu \mathrm{g} / \mathrm{g})\end{array}$} & $\begin{array}{l}\text { Sandia } \\
\text { Perimeter } \\
\text { Community }\end{array}$ & $\begin{array}{r}18 \\
8 \\
5 \\
\end{array}$ & $\begin{array}{l}2.4 \\
2.5 \\
2.5 \\
\end{array}$ & $\begin{array}{l}0.3 \\
0.2 \\
0.2 \\
\end{array}$ & $\begin{array}{l}2.0 \text { to } 2.9 \\
2.0 \text { to } 2.7 \\
2.3 \text { to } 2.8 \\
\end{array}$ \\
\hline & Total & 31 & 2.45 & 0.3 & 2.0 to 2.9 \\
\hline \multirow[t]{2}{*}{$\begin{array}{l}137 \mathrm{Cs} \\
(\mathrm{pCi} / \mathrm{g})\end{array}$} & $\begin{array}{l}\text { Sandia } \\
\text { Perimeter } \\
\text { Community }\end{array}$ & $\begin{array}{r}18 \\
8 \\
5 \\
\end{array}$ & $\begin{array}{l}0.50 \\
0.32 \\
0.25 \\
\end{array}$ & $\begin{array}{l}0.15 \\
0.30 \\
0.32 \\
\end{array}$ & $\begin{array}{r}0.10 \text { to } 0.70 \\
0.01 \text { to } 0.88 \\
\leq 0.02 \text { to } 0.79 \\
\end{array}$ \\
\hline & Total & 31 & 0.41 & 0.22 & 0.01 to 0.88 \\
\hline \multirow[t]{2}{*}{$\begin{array}{l}{ }^{3} \mathrm{H} \\
(\mathrm{pCi} / \mathrm{ml})\end{array}$} & $\begin{array}{l}\text { Sandia } \\
\text { Perimeter } \\
\text { Community }\end{array}$ & $\begin{array}{r}18 \\
8 \\
5 \\
\end{array}$ & $\begin{array}{l}5.6 \\
7.3 \\
7.4 \\
\end{array}$ & $\begin{array}{l}2.7 \\
0.9 \\
1.7 \\
\end{array}$ & $\begin{array}{r}1.8 \text { to } 11.2 \\
6.3 \text { to } 8.6 \\
5.5 \text { to } 9.4 \\
\end{array}$ \\
\hline & Total & 31 & 6.3 & 2.3 & 1.8 to 11.2 \\
\hline
\end{tabular}

range of values for radionuclides in each of the three types of sampling locations.

Uranium concentrations in soll ranged from 2.0 to $2.9 \mu \mathrm{g} / \mathrm{g}$ and are consistent with natural background levels. Differences between locations were not statistically significant. The $137 \mathrm{Cs}$ concentrations ranged from $<0.01$ to $0.88 \mathrm{pCi} / \mathrm{g}$ and appear to reflect fallout levels of $137 \mathrm{Cs}$. Tritium concentrations ranged from 1.8 to $11.2 \mathrm{pCi} / \mathrm{ml}$. Concentration differences between locations were not statistically significant. The uranium and ${ }^{137} \mathrm{Cs}$ concentrations were very close to those of past years, while the ${ }^{3} \mathrm{H}$ concentrations were lower compared to the $3_{\mathrm{H}}$ results in 1988 .

\section{Water}

Concentrations of gross $\alpha, \beta, 137 \mathrm{Cs}, 3_{\mathrm{H}}$, and uranium in water are reported for all sample locations in Tables F-3 and F-4 for both total (unfiltered) water $(T)$ as well as filtered water (F) and associated suspended solids (S). Table F-3 lists concentrations in surface waters while Table F-4 lists concentrations in groundwater. Tables $5-4$ and $5-5$ summarize the water sampling results for both well and surface water locations. 
Table 5-4. Mean* Concentrations of Gross $\alpha$, Gross $\beta$, Uranium, ${ }^{137} \mathrm{Cs}$ and ${ }^{3} \mathrm{H}$ in Surface Water (Streams)

\begin{tabular}{|c|c|c|c|}
\hline $\begin{array}{l}\text { Analysis } \\
\text { (Units) }\end{array}$ & $\begin{array}{c}\text { Total Water } \\
x \pm s^{* \star}\end{array}$ & $\begin{array}{l}\text { Filtered Water } \\
\qquad \mathrm{s}_{* \star}\end{array}$ & 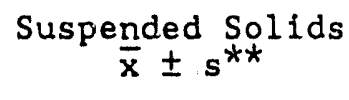 \\
\hline $\begin{array}{l}\operatorname{Gross} \alpha \\
\left(10^{-9} \mu \mathrm{Ci} / \mathrm{ml}\right)\end{array}$ & $<2.8$ & $<3.2$ & $<0.7$ \\
\hline $\begin{array}{l}\text { Gross } \beta \\
\left(10^{-9} \mu \mathrm{Ci} / \mathrm{ml}\right)\end{array}$ & $<21$ & $<19.6$ & $<0.4$ \\
\hline $\begin{array}{l}\text { Uraniurn } \\
(10-3 \mu \mathrm{g} / \mathrm{ml})\end{array}$ & $<1.5$ & $<1.5$ & - \\
\hline $\begin{array}{l}137 \mathrm{Cs} \\
\left(10^{-9} \mu \mathrm{Ci} / \mathrm{ml}\right)\end{array}$ & $<0.01$ & $<0.01$ & - \\
\hline $\begin{array}{l}{ }^{3} \mathrm{H} \\
(10-6 \mu \mathrm{Ci} / \mathrm{ml})\end{array}$ & $<0.45$ & $<0.45$ & . \\
\hline \multicolumn{4}{|c|}{$\begin{array}{l}\text { * Summary data for three surface water locations. Individual values are } \\
\text { in Appendix } F \text {, Table F- } 3 \text {. } \\
\text { ** Standard deviation } s \text { values were not calculated because all results are } \\
\text { less than detection levels. }\end{array}$} \\
\hline
\end{tabular}

Gross alpha, $\beta$, uranium, and $137 \mathrm{Cs}$ concentrations in water were all less than MDL values and are consistent with background levels and results of previous years.

$\underline{\text { TLD }}$

Table 5.6 gives the summary of annual TLD dose estimates for SNL perimeter, and community locations noted in Table 5-1. Data for individual locations are in Appendix $F$, Table $F-5$. These estimates include natural background plus facility contributions (if any). The mean annual doses for 12 community and seven perimeter (SNL, Albuquerque, boundary) locations were 93 mrem and 98 mrem, respectively. The mean annual dose at locations adjacent to onsite facilities was $116 \mathrm{mrem} / \mathrm{yr}$. The mean annual external penetrating radiation dose for all location types was $103 \mathrm{mrem} / \mathrm{yr}$, which is not statistically different from the values of perimeter and community locations (Table 5-6).

There was no significant difference between the three location types in annual dose estimates. The onsite annual dose estimate is higher than perimeter and offsite areas primarily due to location 41 . Location 41 , on 
Table 5-5. Mean* Concentrations of Gross $\alpha$, Gross $\beta$, Uranium, $137 \mathrm{Cs}$ and $3 \mathrm{H}$ in Groundwater (Base Wells).

\begin{tabular}{|c|c|c|c|}
\hline $\begin{array}{l}\text { Analysis } \\
\text { (Units) }\end{array}$ & $\begin{array}{c}\text { Total Water } \\
\qquad \mathbf{s}^{\star \star}\end{array}$ & $\begin{array}{c}\text { Filtered Water } \\
x \pm s 3^{* *}\end{array}$ & $\begin{aligned} \text { Suspended Solids } \\
$\[ s^{* *} \]$\end{aligned}$ \\
\hline $\begin{array}{l}\text { Gross } \alpha \\
\left(10^{-9} \mu \mathrm{Ci} / \mathrm{ml}\right)\end{array}$ & $<3.5$ & $<2,8$ & $<0.03$ \\
\hline $\begin{array}{l}\text { Gross } \beta \\
\left(10^{-9} \mu \mathrm{Cl} / \mathrm{ml}\right)\end{array}$ & $<18.5$ & $<18.5$ & $<0.4$ \\
\hline $\begin{array}{l}\text { Uranium } \\
\left(10^{-3} \mathrm{\mu g} / \mathrm{ml}\right)\end{array}$ & $<1.5$ & $<1.5$ & - \\
\hline $\begin{array}{l}137 \mathrm{Cs} \\
\left(10^{-9} \mu \mathrm{C} 1 / \mathrm{m} 1\right)\end{array}$ & $<0.01$ & $<0.01$ & - \\
\hline $\begin{array}{l}{ }^{3} \mathrm{H} \\
(10-6 \mu \mathrm{Cl} / \mathrm{ml})\end{array}$ & $<0.45$ & $<0.45$ & - \\
\hline \multicolumn{4}{|c|}{$\begin{array}{l}\text { * Summary data for five well water locations. Individual values are in } \\
\text { Appendix F. Table F- } 4 \text {. } \\
\text { ** Standard deviation, } s \text { values were not calculated because all results are } \\
\text { less than detection levels. }\end{array}$} \\
\hline
\end{tabular}

Table 5-6. Summary of TLD Measurements**

\begin{tabular}{|c|c|c|c|c|}
\hline \multirow[b]{2}{*}{ Location } & \multirow[b]{2}{*}{$\begin{array}{c}\text { Sample } \\
\text { Size }\end{array}$} & \multicolumn{3}{|c|}{ Mean Annual Dose (mrem/yr) } \\
\hline & & $\bar{x}$ & ${ }^{s} \bar{x}$ & Range \\
\hline Sandia (S) & 13 & 116 & 13 & 90 to $277^{*}$ \\
\hline Perimeter (P) & 7 & 98 & 4 & 85 to 111 \\
\hline Community (C) & 12 & 93 & 3 & 79 to 109 \\
\hline Total & 32 & 103 & 5 & 79 to 277 \\
\hline
\end{tabular}


the radiation control fence northeast of Area $V$, was significantly higher than other SNL, Albuquerque, locations. These higher values can be attributed to controlled operations at the HERMES-II accelerator in Area $V$. The mean annual dose from all other 12 onsite locations averaged $102 \pm$ $9 \mathrm{mrem} / \mathrm{yr}$.

\subsection{Potential Dose Assessment for the Public}

A radiation dose assessment of the public residing near the site from routine operations at SNL, Albuquerque, was performed using the AIRDOS-EPA computer code for the calendar year 1989. All doses presented in this section are based on the RADRISK model for dose rate conversion and are calculated for the compliance purposes of NESHAP (40 CFR 61, Subpart H) regulations and DOE Order 5400.1

As indicated in section 5.1, there are few facilities within SNL, Albuquerque, that routinely generate radioactive emissions. Most of these facilities are located in Technical Areas $I V$ and $V$, and most of the radioactive releases are air emissions. Therefore, air dose is the only radiological dose impact to the offsite residence from routine operations at SNL, Albuquerque.

\section{Release Sources}

The radioactive air emissions from SNL, Albuquerque, during calendar year 1989 include $41_{\mathrm{Ar}}(8.8 \mathrm{CI})$ and $133 \mathrm{Xe}(0.6 \mathrm{Ci})$ from the reactors (ACRR, SPR) in Area $V ;{ }^{13} \mathrm{~N}(0.23 \mathrm{Ci})$ and $150(0.21 \mathrm{Ci})$ from the HERMES-III accelerator in Area IV; $3 \mathrm{H}$ (in micro-Ci) from neutron generator testing in Area $\mathrm{II}$; and very small quantities of depleted uranium from Area III and Area I. Most of these emissions are too small to measure by instruments. Therefore, they are estimated by very conservative calculations. The airborne radioactive emission sources axe summarized in Table 5-7.

\section{Meteorological Data}

The meteorological data used in the dose calculations for SNL, Albuquerque, is from the Albuquerque International Airport, an average distance of approximately $3.5 \mathrm{mi}$ from the SNL, Albuquerque, release locations. The joint frequency wind distribution is a 5-yr average, provided by the National Climatic Center (NCC) in Ashville, South Carolina. The Pasquill stability class analysis was performed using the STAR program provided by the NCC. The period of record is 1960 to 1964 inclusive for Albuquerque, New Mexico. All of these meteorological data were updated in March 1990 before the final dose calculation was performed.

\section{Demographic Data}

The calculation of demographic data includes population, beef cattle, dairy cattle, and food crops used for human consumption. These four parameters were calculated for each of the AIRDOS-EPA gridded zones (total of 80 ). In 
Table 5-7. Summary of Airborne Radioactive Emissions

\begin{tabular}{|c|c|c|c|c|}
\hline Facility & Nuclide & Half-Life & Activity & Released in 1989 \\
\hline ACRR* & $\begin{array}{l}\text { Ar }-41 \\
\text { Xe }-133\end{array}$ & $\begin{array}{l}1.8 \mathrm{~h} \\
5.2 \mathrm{~d}\end{array}$ & & $\begin{array}{l}8.1 \mathrm{Ci} \\
0.6 \mathrm{Ci} * * *\end{array}$ \\
\hline SPR* & $\operatorname{Ar}-41$ & $1.8 \mathrm{~h}$ & & $0.7 \mathrm{Ci}$ \\
\hline HERMES III* & $\begin{array}{l}N-13 \\
0-15\end{array}$ & $\begin{array}{r}10.0 \mathrm{~m} \\
122.0 \mathrm{~s}\end{array}$ & & $\begin{array}{l}0.23 \mathrm{Ci} \\
0.21 \mathrm{Ci}\end{array}$ \\
\hline $935(A-I I)$ & $\mathrm{H}-3$ & $12.3 \mathrm{y}$ & & $<50 \mu \mathrm{Ci} \star \star$ \\
\hline $9939(A-I I I)$ & $U-238$ & $4.5 \times 1.0^{9} y$ & & $<10 \mu \mathrm{Ci} * *$ \\
\hline \multicolumn{5}{|c|}{$\begin{array}{l}\text { *The amounts released were calculated based on theoretical parameters and } \\
\text { conservative assumptions. } \\
* * \text { The amounts were estimated based on previous experiences. } \\
* * * \text { The } 0.6 \mathrm{Ci} \text { quoted is mostly } \mathrm{Xe}-133 \text {, although there may be a small } \\
\text { portion of } \mathrm{Kr}-85 \text {. }\end{array}$} \\
\hline
\end{tabular}

general, demographic data is available by county, and the densities for population, beef cattle, dairy cattle, and food crops are calculated as the quotient of the most recent county data and the county land area. For 1989 calculations, the 1980 Census and the 1988 agricultural data were utilized. A total of 422,711 people, 31,038 beef cattle, 6,618 dairy cattle, and $2.4 \times 10^{8} \mathrm{~m}^{2}$ of food crops were used from the surrounding nine counties.

Results of the Dose Assessment

Doses were calculated using the AIRDOS-EPA computer code and the RADRISK model for two groups of receptors around SNL, Albuquerque. The first group is the seven historical receptors analyzed in the previous monitoring reports (Table 5-8) including NW Base Housing, Four Hills, $\mathrm{N}$ Base Housing, the DOE Complex, the communities of Mountain View and Tijeras, and the Isleta Gate. Excluding the Isleta Gate, the remaining six receptors have residents or offices. The highest individual dose among these six receptors is $6.0 \times 10^{-4} \mathrm{mrem}$ at the DOE/AL office complex.

The second group (Table 5-9) lists additional receptors at potential maximum public impact locations (where there is a residence, school, business, or nffice) as required by 40 CFR 61.94, "Compliance and Reporting" of the NESHAP regulations. The second group includes Tijeras 
Table 5-8. 1989 Dose Calculations of the Seven Historic Receptors for Sandia National Laboratories, Albuquerque

\begin{tabular}{|c|c|c|c|c|}
\hline & Location & $\begin{array}{l}\text { Distance } \\
\text { From A-V }\end{array}$ & $\begin{array}{l}\text { Direction } \\
\text { Degrees }\end{array}$ & $\begin{array}{c}\text { Whole Body Dose } \\
\text { mrem } / y^{r} \\
\times 10^{-3}\end{array}$ \\
\hline 1. & $\begin{array}{l}\text { NW Base Housing } \\
\text { W. Penn. Ave. } \\
\text { S. Gibson } \\
\text { NW Site Boundary }\end{array}$ & $5.8 \mathrm{~km}$ & $337^{\circ} \mathrm{NW}$ & 0.48 \\
\hline 2. & $\begin{array}{l}\text { Four Hills } \\
\text { By TLD Station } \\
\text { NE Site Boundary }\end{array}$ & $5.6 \mathrm{~km}$ & $26^{\circ} \mathrm{NE}$ & 0.41 \\
\hline 3. & $\begin{array}{l}N \text { Base Housing } \\
N \text {. of Gibson } \\
E \text {. of Wyoming } \\
N \text { Site Boundary }\end{array}$ & $6.1 \mathrm{~km}$ & $350^{\circ} \mathrm{N}$ & 0.55 \\
\hline 4. & $\begin{array}{l}\text { TLD Station } \\
\text { NW DOE Complex } \\
\text { NW Site Boundary }\end{array}$ & $6.2 \mathrm{~km}$ & $339^{\circ} \mathrm{NW}$ & 0.60 \\
\hline 5. & $\begin{array}{l}\text { "Mountain View" } \\
\text { W. of KAFB } \\
\text { Community }\end{array}$ & $11.2 \mathrm{~km}$ & $268^{\circ} \mathrm{W}$ & 0.10 \\
\hline 6. & $\begin{array}{l}\text { "Tijeras" } \\
\text { E. of KAFB } \\
\text { Community, near } \\
\text { TLD (Intersection } \\
\text { I-40/S-14) }\end{array}$ & $16.0 \mathrm{~km}$ & $54^{\circ} \mathrm{NE}$ & 0.06 \\
\hline 7. & $\begin{array}{l}\text { "Isleta Gate" } \\
\text { S. Site Boundary } \\
\text { By TLD Station }\end{array}$ & $5.7 \mathrm{~km}$ & $180^{\circ} \mathrm{S}$ & 1.0 \\
\hline
\end{tabular}

Arroyo, the City Landfill, the airport (west end), the SE corner of NW Base Housing, the Eubank Gate, NE and E residents, Isleta Mine and $W$ residences. The locations of these receptors are shown in Figure 5-4.

The highest offsite dose impact for 1989 operations was $8.8 \times 10^{-4} \mathrm{mrem} / \mathrm{yr}$ at the Tijeras Arroyo receptor, located about $200 \mathrm{~m}$ west of the western (SNL, Albuquerque boundary) KAFB boundary. The maximum critical organ dose was calculated to be $8.3 \times 10^{-4} \mathrm{mrem} / \mathrm{yr}$ to the lungs at the Tijeras Arroyo 


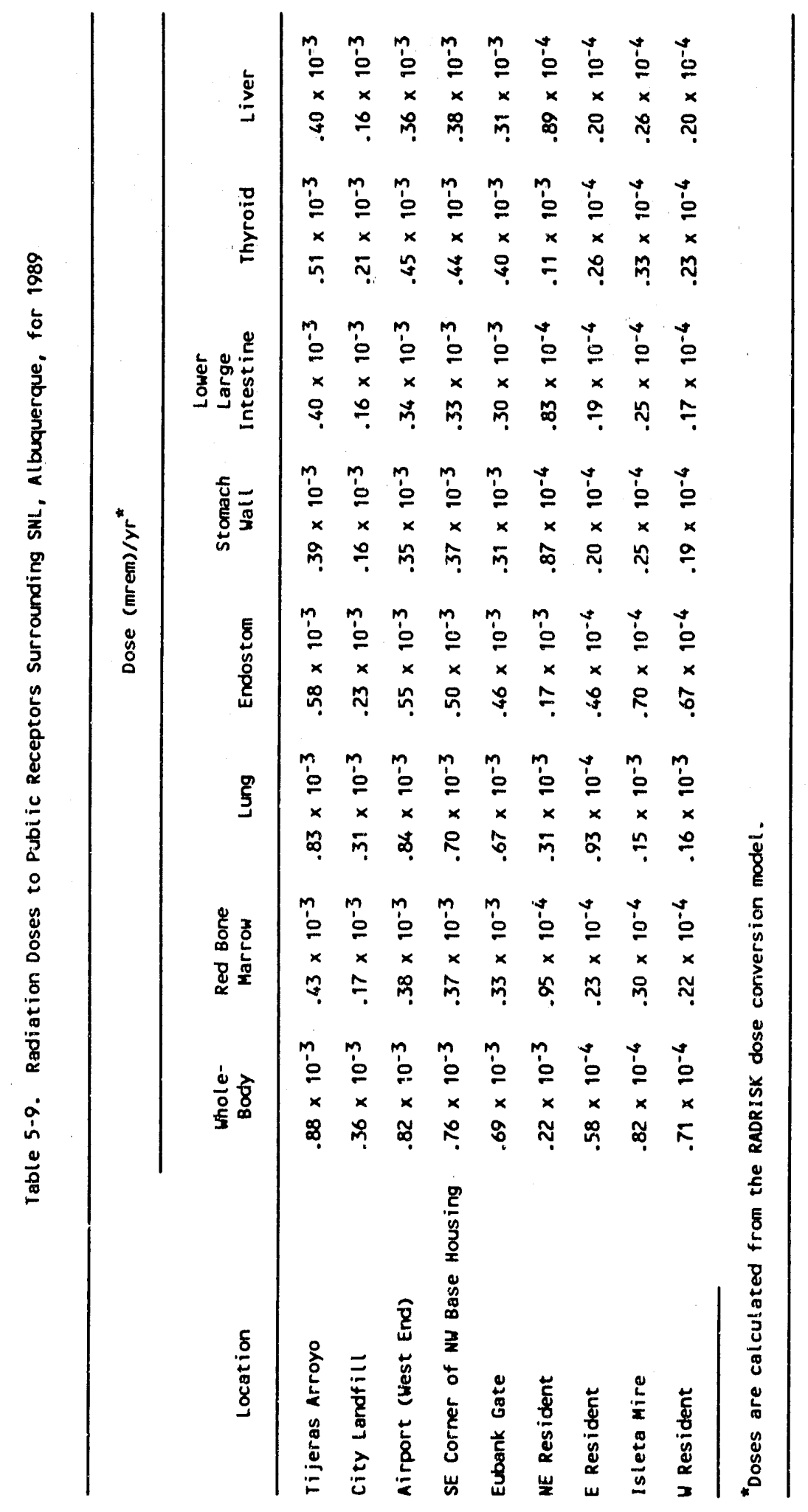




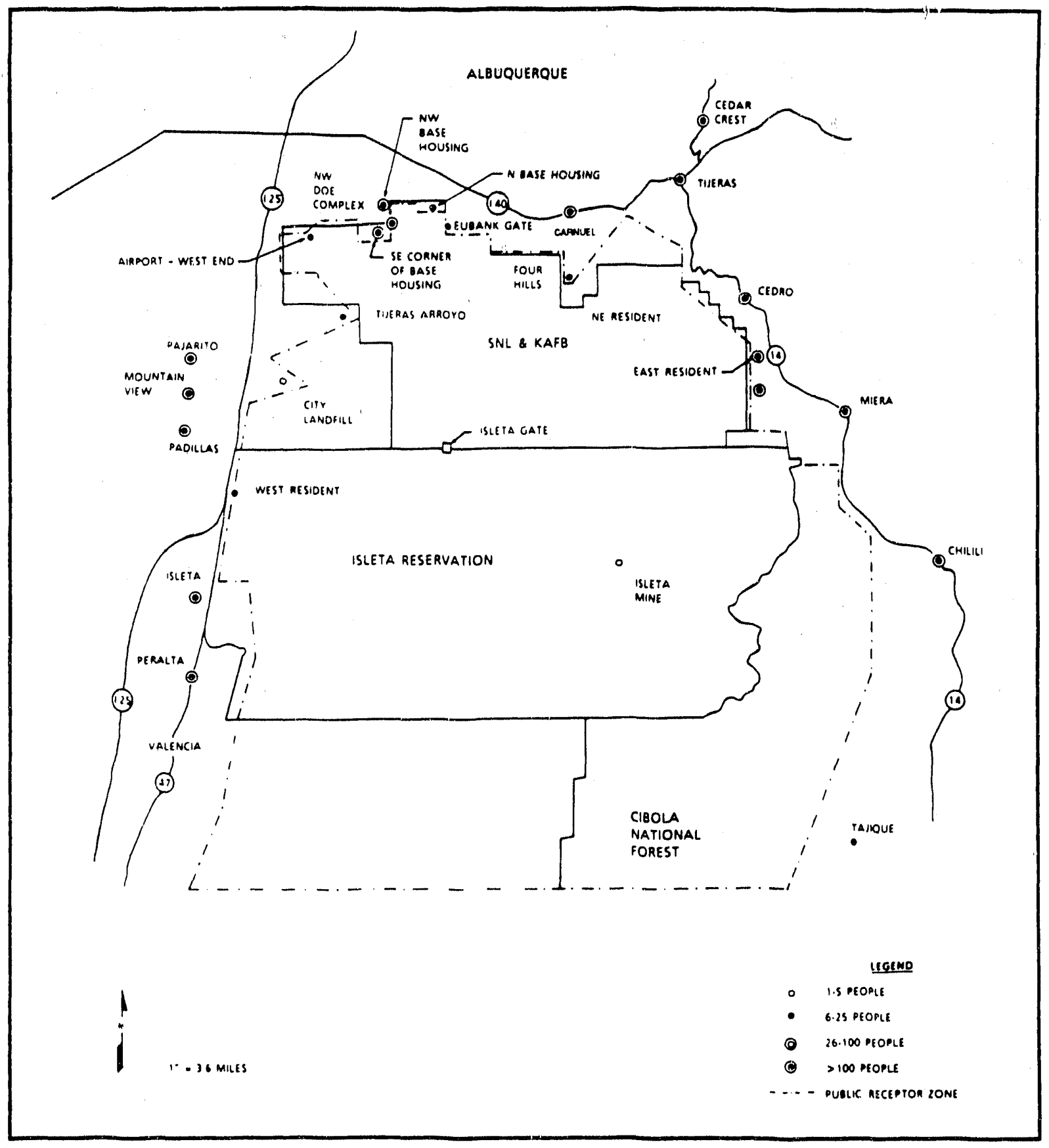

Figure 5-4. Offsite Receptor Locations of Potential Maximum Dose Impacts 
receptor. The dose was primarily due to external air immersion in $41 \mathrm{Ar}$ and secondarily due to the inhalation of $238 \mathrm{U}$. These doses are negligible compared to nature background radiation ( $99 \mathrm{mrem} / \mathrm{yr}$ ) and are well below the $25 \mathrm{mrem} / \mathrm{yr}$ (whole body) and $75 \mathrm{mrem} / \mathrm{yr}$ critical organ dose limits specified in NESHAP (40 CFR 61, Subpart H) standards.

The population dose as a result of SNL, Albuquerque, operations was calculated for the $50-\mathrm{mi}$ radius surrounding a single common grid analysis for all sources. Because the analysis area is so large, the relatively small distances between sources will not have any significant impact on the calculations. Demographic data based on 1980 population data and 1988 agricultural data were employed. The resulting population dose was found to be 0.097 person-rem for the $50-\mathrm{mi}$ (or $80 \mathrm{~km}$ ) population. The summary of maximum receptor whole-body dose, critical organ dose, and annual population dose in comparison to NESHAP standards and to natural background radiation is presented in Table 5-10.

Table 5-10. Summary of Offsite Dose Impacts in Comparison to NESHAP Standards and the Nature Background Radiation

\begin{tabular}{|c|c|c|c|}
\hline Parameters & $\begin{array}{l}\quad 1989 \\
\text { SNL, Albuquerque, } \\
\text { Calculated Dose }\end{array}$ & $\begin{array}{l}\text { NESHAPs } \\
\text { Standards }\end{array}$ & $\begin{array}{l}\text { Natural Background } \\
\text { Radiation in } \\
\text { Albuquerque Area }\end{array}$ \\
\hline $\begin{array}{l}\text { Max, whole-body } \\
\text { dose (mrem/yr) }\end{array}$ & $8.8 \times 10^{-4}$ & 25 & $93 *$ \\
\hline $\begin{array}{l}\text { Max. critical organ } \\
\text { dose (mrem/yr) }\end{array}$ & $\begin{array}{l}8.3 \times 10^{-4} \\
\text { (1ung) }\end{array}$ & 75 & $\cdots$ \\
\hline $\begin{array}{c}* * \text { Annual Population } \\
\text { dose (person-rem) }\end{array}$ & 0.097 & - & $>40,000$ \\
\hline \multicolumn{4}{|c|}{$\begin{array}{l}\text { *Based on the average of community TLD values (whole-body dose from } \\
\text { external penetrating radiation). } \\
* * \text { Dose over the population of } 80-\mathrm{km} \text { radius surrounding SNL, Albuquerque. }\end{array}$} \\
\hline
\end{tabular}




\section{CHAPTER 6}

\section{NONRADIOLOGICAL MONITORING}

\subsection{Waste Water, Storm Water, and Surface Discharge Programs}

\subsubsection{Waste Water Programs}

\section{Discharges to POTW}

SNL, Albuquerque, has about $15 \mathrm{mi}$ of sewer lines which are interconnected with those of KAFB. On August 31, 1986, SNL, Albuquerque, submitted a wastewater discharge application to the City of Albuquerque. SNL, Albuquerque, received its first Wastewater Discharge Permits from the City of Albuquerque, Liquid Waste Division, on January 19, 1987. Because SNL, Albuquerque, has several connections to the City of Albuquerque sew 5 . system and three categorical pretreatment operations, five Wastewater Discharge Permits were issued.

Discharges by SNL, Albuquerque, to POTWs are regulated by the City of Albuquerque, Liquid Waste Division under the authority of the City of Albuquerque Sewer Use and Wastewater Control Ordinance. The City's ordinance is approved by the EPA in accordance with the CWA (as amended).

In order to remain in compliance with EPA regulations that implement the CWA, the City has implemented a pretreatment program. This program requires SNL, Albuquerque, to obtain permits for discharges to the City of Albuquerque POTW. The permits specify the required quality of discharges, the requirements for periodic monitoring of the discharges, and the frequency of reporting the results of the monitoring.

At the beginning of 1989, SNL, Albuquerque, operated under five wastewater discharge permits issued by the City of Albuquerque, Liquid Waste Division. A sixth permit was applied for on February 27, 1989, and a permit was issued that became effective on August 1, 1989. Four of the six permits contained provisions for meeting categorical limits established by the EPA. The permits in Table 6-1 that have a 40 CFR designation in the "Issuing Agency" column contain EPA categorical discharge limitations.

Further details about the wastewater sampling program are found in Appendices B, C, D, and F. Table 6-2 describes the wastewater sampling locations and brief characteristics of each. Appendix $C$ (Tables $\mathrm{C}-2$ to C-7) describes sampling procedures and permit limits for individual sampling stations. Table D-2 in Appendix D provides analytical methods, quality control (QC) acceptance criteria, and detection limits for individual parameters. Appendix $E$ briefly describes the wastewater sampling QA data. Appendix F, Tables F-13 to F-18, provides the results of analyses on wastewater samples. 
Table 6-1. Waste Water Discharge Permits, SNL, Albuquerque

\begin{tabular}{|c|c|c|c|c|}
\hline $\begin{array}{l}\text { Permit } \\
\text { Number }\end{array}$ & $\begin{array}{l}\text { Station } \\
\text { Manhole }\end{array}$ & $\begin{array}{c}\text { Waste Stream } \\
\text { Process }\end{array}$ & $\begin{array}{l}\text { Issuing } \\
\text { Agency }\end{array}$ & $\begin{array}{l}\text { Permit } \\
\text { Expiration }\end{array}$ \\
\hline $2069 A$ & WW001 & General & City of $A B Q$ & $6-30-90$ \\
\hline $20690-2$ & WW003 & $\begin{array}{l}\text { Electroplating/ } \\
\text { printed circuit } \\
\text { board }\end{array}$ & $\begin{array}{l}\text { City of ABQ/ } \\
40 \text { CFR } 413.84\end{array}$ & $6-30-90$ \\
\hline $2069 D-2$ & WW004 & Metal Finishing & $\begin{array}{l}\text { City of } A B Q / \\
40 \text { CFR } 433 . A 15 e\end{array}$ & $6-30-90$ \\
\hline $2069 E-2$ & WW005 & Electronics & $\begin{array}{l}\text { City of ABQ/ } \\
40 \text { CFR Part } 469 . \text { A }\end{array}$ & $9-30-93$ \\
\hline $2069 \mathrm{~F}$ & WW006 & General & City of $A B Q$ & $6-30-90$ \\
\hline $2069 G$ & WW007 & $\begin{array}{l}\text { Microelectronics } \\
\text { Development Lab }\end{array}$ & $\begin{array}{l}\text { City of ABQ/ } \\
40 \text { CFR Part } 469 . \mathrm{A}\end{array}$ & $7-31-91$ \\
\hline
\end{tabular}

Compliance Summary

The discussion in this section addresses those instances in which the monitoring results were not in compliance with the permit limits described in Appendix C, Tables $\mathrm{C}-3$ to $\mathrm{C}-7$.

Permit 2069A--Permit 2069A is a general wastewater discharge permit for wastewater discharges from a portion of Siandia-Albuquerque Technical Area I.

$\underline{\mathrm{pH}}$

Equipment malfunction prevented the measurement of $\mathrm{pH}$ at station WW 001 during the months of January and February, 1989. On April 6, 1989, $\mathrm{pH}$ fell below the permit limit of 5.0 for 2 hr. The pH monitoring equipment was installed December 1988 and one component malfunctioned. A replacement was not obtained until February 1989. Spares of all pH and flow monitoring equipment are now kept on hand. Source of flow $\mathrm{pH}$ wastewater was never determined.

Permit 2069C-2--Permit 2069C-2 is a permit that covers discharges from the categorically regulated printed circuit development activity in Building 841, SNL, Albuquerque, Technical Area I. This permit is a renewal of Permit 2069C that expired in 1988. 
Tab1e 6-2. SNL, Albuquerque, Waste Water Sample Locations

\begin{tabular}{|c|c|c|}
\hline $\begin{array}{l}\text { Station } \\
\text { Number }\end{array}$ & Location & $\begin{array}{l}\text { Average* } \\
\text { Flow (gpd) }\end{array}$ \\
\hline WW001 & $\begin{array}{l}\text { South Area IV } \\
\text { Tijeras Arroyo }\end{array}$ & 254,300 \\
\hline WW003 & $\begin{array}{l}\text { Area I } \\
\text { Bldg. } 8 /+1 \text { SW }\end{array}$ & $15,000^{*}$ \\
\hline WW004 & $\begin{array}{l}\text { Area I } \\
\text { B1dg. } 841 . \text { SE }\end{array}$ & 38,300 \\
\hline WW005 & $\begin{array}{l}\text { Area I } \\
\text { Bldg. } 870 \mathrm{sW}\end{array}$ & 227,200 \\
\hline WW006 & E. of KAFB Lagoons & 529,266 \\
\hline WW007 & $\begin{array}{l}\text { Area I } \\
\text { Bldg. } 858 \text { Basement }\end{array}$ & 56,100 \\
\hline
\end{tabular}

Copper

Copper was detected at a concentration of 180 milligrams per liter $(\mathrm{mg} / \mathrm{l})$ in the March 14, 1989, 24-hr composite, and at $170 \mathrm{mg} / 1$ in the sample duplicate. These concentrations exceeded the $10.2 \mathrm{mg} / 1$ permitted maximum allowable concentration limit for 1-day composite samples. In addition, as a result of the excursion, the $6.0 \mathrm{mg} / 1$ permitted maximum allowable concentration limit for 4-day composite samples for copper was exceeded with a 4-day average concentration of $45.3 \mathrm{mg} / 1$.

The cause of the copper violation was due to a set of worn rollers in a ferric chloride etching machine in Building 841 . To correct the $\mathrm{pH}$ violation, the worn rollers were replaced and the rinse water was recirculated in the machine.

Permit 2069D-2--Permit 2069D-2 covers discharges from the categorically regulated metal-plating research and development activity in Building 841, SNL, Albuquerque, Technical Area. I. This permit is a renewal of Permit 2069D that expired in 1988. 
pH

Three excursions of 1 -hr or more duration from the allowable $\mathrm{pH}$ range of 5.0 to 11.0 were detected by the continuous $\mathrm{pH}$ monitoring equipment at station WW004. On April 24, 1989, pH fell below 5.0 for $1 \mathrm{hr}$; on July 10, 1989, pH fell below 5.0 for $1 \mathrm{hr}$; and on July $27,1989, \mathrm{pH}$ fell below 5.0 for $1.5 \mathrm{hrs}$.

The cause of the $\mathrm{pH}$ violation was investigated and not found. The low $\mathrm{pH}$ discharge is assumed to be of low volume because no related $\mathrm{pH}$ deflections are evident at the downstream monitoring station wW006.

Actions to locate the source of the discharges have included the elimination of discharges from the Plating Lab in Building 841, the evaluation and elimination of discharges from a paint stripping rinse tank in Building 841 , and an audit of all factlities discharging to monitoring station WW004.

Because these violations no longer occur, no further investigation is being performed.

Permit 2069E-2-Permit 2069E-2 covers the discharges from the categorically regulated semiconductor production astivity conducted by Allied Sigiual Corporation, Albuquerque Microelectronics Operations (AMO) in Building 870 , SNL, Albuquerque, Technical Area $I$. This permit is a renewal of Permit $2069 \mathrm{E}$ that expired in 1989.

$\mathrm{pH}$

During 1989, at station Ww005, pH excursions beyond permit limits of 5.0 to 11.0 of $1 \mathrm{hr}$ or greater duration wexe noted on 16 days; in addition, one month experienced cumulative $\mathrm{pH}$ excursions amounting to greater than the $7 \mathrm{hr}$ and $26 \mathrm{~min}$ allowed per calendar month. Specific findings are summarized in Table 6-3.

The cause of the pH violations was determined to be from the discharge of certain processes. To correct the $\mathrm{pH}$ violations, all acid waste processes to the Elementary Neutralization Unit (ENU) were rerouted, a manually operated chemical feed system to handle slug loads to the ENU was added, and the ENU was upgraded to provide additional and more responsive neutralization capability. The ENU upgrade modifications were completed before the end of 1989.

Permit 2069F--Permit $2069 \mathrm{~F}$ is a general permit that covers wastewater discharges from a portion of SNL, Albuquerque, Technical Area $I$ and some DOE and KAFB facilities.

$2 \mathrm{H}$

Malfunction of continunus ph monitoring equipment prevented collection of data during part of the months of February and March 1989. The pH 
Table 6-3. Summary of pH Excursions for Station WW005 During 1989

\begin{tabular}{|c|c|c|c|}
\hline Date & pH Value & $\begin{array}{l}\text { Duration } \\
\text { (hr) }\end{array}$ & $\begin{array}{c}\text { Monthly Total } \\
\text { (hr) }\end{array}$ \\
\hline $\begin{array}{r}\text { Jan. } 2 \\
4 \\
17 \\
24\end{array}$ & $\begin{array}{l}<5.0 \\
<5.0 \\
<5.0 \\
<5.0\end{array}$ & $\begin{array}{l}2.0 \\
1.0 \\
1.0 \\
1.0\end{array}$ & 5.0 \\
\hline Feb. 28 & $>11.0$ & 1.0 & 1.0 \\
\hline $\begin{array}{r}2 \\
23 \\
28\end{array}$ & $\begin{array}{l}>11.0 \\
<5.0 \\
<5.0\end{array}$ & $\begin{array}{l}1.25 \\
2.0 \\
1.5\end{array}$ & 4.75 \\
\hline $\begin{array}{r}4 \\
5 \\
6 \\
11 \\
17\end{array}$ & $\begin{array}{l}<5.0 \\
<5.0 \\
<5.0 \\
<5.0 \\
<5.0\end{array}$ & $\begin{array}{l}3.0 \\
2.0 \\
5.0 \\
2.0 \\
1.0\end{array}$ & 13.0 \\
\hline $\begin{array}{l}\text { May } 5 \\
16\end{array}$ & $\begin{array}{l}<5.0 \\
>11.0\end{array}$ & $\begin{array}{l}1.0 \\
1.25\end{array}$ & 2.25 \\
\hline June 12 & $<5.0$ & 1.5 & 1.5 \\
\hline
\end{tabular}

monitoring equipment is now checked daily, and spares of equipment are kept on hand.

Permit 2069G--Permit 2069 G covers discharges from the categorically regulated microelectronics R\&D programs conducted at the Microelectronics Development Laboratory (MDL) in Building 858, SNL, Albuquerque, Technical Area I. Permit $2069 \mathrm{G}$ became effective on August 1, 1989. Prior to August 1. 1989, discharges from the MDL were sampled and compared to maximum permitted concentrations set forth in Permit 2069E-2. Violations from both sampling periods are noted as follows:

\section{Fluoride}

Fluoride concentrations exceeded permit limit values twice during the period preceding the August 1, 1989, starting date for Permit 2069G and twice after August 1. In each instance, the exceedance occurred In a 24-hr composite sample, which caused exceedance of the 4-day average permit limit. The fluoride violations are summarized in Table 6.4. 
Table 6-4. Summary of Fluoride Exceedances at MDL During 1989

\begin{tabular}{lcc}
\hline Sample Date/Type & $\begin{array}{c}\text { Concentration } \\
\mathrm{mg} / 1\end{array}$ & $\begin{array}{c}\text { Permit Limit } \\
\mathrm{mg} / 1\end{array}$ \\
\hline Compared to Permit 2069E-2: & & \\
April 14, 24-hr & 70 & 45 \\
April 4-day average & 32 & 30 \\
June 28, 24-hr & 130 & 45 \\
June 4-day average & 50 & 30 \\
Under Permit \#2069G: & & \\
October 24, 24-hr & 98 & 45 \\
October 4-day average & 33 & 30 \\
November 17, 24-hr & 230 & 45 \\
November 4-day average & 68 & 30 \\
\hline
\end{tabular}

The cause of excess fluoride was determined to be from the discharge of certain processes. It was determined that strict administrative controls and additional pretreatment were necessary to prevent further violations. Modifications are being designed to control the fluoride content of the wastewater and upgrade the neutralization system. Installation and performance tests are expected to be complete by November 1990 .

\section{Annual Sampling}

Annual sampling for all parameters is specified in wastewater discharge permits of SNL, Albuquerque, (Appendix C and Figure 6-1). Annual 24-hr composite sampling for all parameters specified in City permits was conducted during June 1989. The results were all less than the concentration limits established by the permits. The results of the annual sampling analyses are contained in Tables $6-5$ and $6-6$.

\section{Discharge to Septic Systems}

In New Mexico, discharge from septic systems is regulated by the Liquid Waste Disposal Regulations and the New Mexico Water Quality Control Commission Regulations. These regulations are administered by the NMEID.

On May 9, 1989, registrarion forms for a total of 65 septic systems were sent to the NMEID in two separate letters. The registered septic systems 


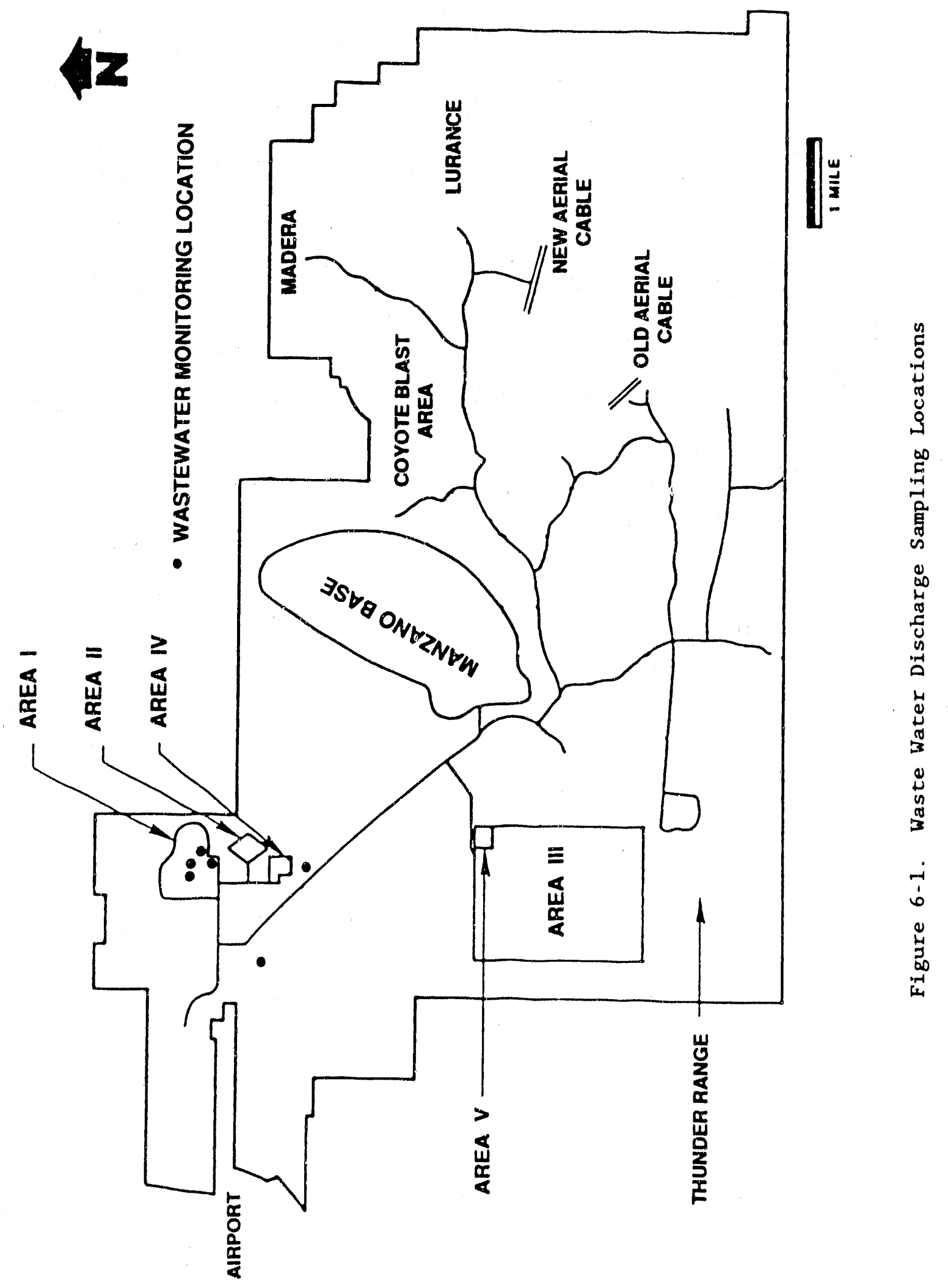


Table 6-5. Sampling Parameters and Concentrations Limits Specified by Surface Water Discharge Plan DP-530

Parameter

Concentration Limit

$\begin{array}{lc}\begin{array}{l}\text { Purgeable and Extractable Organics per } \\ \text { NMWQCC regulations, }\end{array} & \text { Sections 1-101 } \\ \text { UU and 3-103.A Total Dissolved Solids } & 1000 \mathrm{mg} / 1 \\ \text { Chloride } & 250 \mathrm{mg} / 1 \\ \text { Sulfate } & 600 \mathrm{mg} / 1 \\ \text { Alkalinity } & \text { None specified } \\ \text { Sodium } & \text { None specified } \\ \text { Calcium } & \text { None specified } \\ \text { Magnesium } & \text { None specified } \\ \text { Potassium } & \text { None specified }\end{array}$

are listed in Appendix $\mathrm{H}$, Table $\mathrm{H}-2$. At the end of 1989, 13 additional septic systems were being investigated for registration. These septic systems will be registered, if necessary, in 1990.

\subsubsection{Storm Water Programs}

The discharge of storm water from SNL, Albuquerque, facilities is regulated by the statutory authority of the CWA (as amended). To be regulated, the storm water must be discharged to a surface receiving water designated as a water of the U.S., such as the Tijeras Arroyo, which ultimately flows to the Rio Grande. For storm water, the provisions of this act are implemented by the EPA through the National Pollutant Discharge Elimination System (NPDES), described in 40 CFR 122. In New Mexico, NPDES permits are issued by the EPA with some review and concurrence responsibility assigned to the State of New Mexico. If storm water is discharged to a surface impoundment with no subsequent discharge to a receiving water, the discharges may be regulated by the NMEID Ground Water Bureau.

In the Federal Register, dated December 7, 1988, the EPA proposed changes to 40 CFR Parts 122, 123, 124, and 504. The proposed changes define NPDES permitting requirements for storm water discharges. The proposed

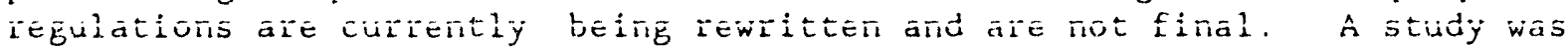


Table 6-6. Summary of Annual One-Day Composite Parameters, SNL, Albuquerque, June 1989*

\begin{tabular}{|c|c|c|c|c|c|}
\hline $\begin{array}{c}\text { Station } \\
\text { Permit } \\
\text { Sample No. } \\
\text { Date Collected }\end{array}$ & $\begin{array}{c}\text { WW001 } \\
2069 A \\
\text { SNLA000339 } \\
06 / 21 / 89\end{array}$ & $\begin{array}{c}\text { WW003 } \\
2069 C-2 \\
\text { SNLA000299 } \\
06 / 28 / 89\end{array}$ & $\begin{array}{c}\text { WW004 } \\
2069 D-2 \\
\text { SNLA000305 } \\
06 / 28 / 89\end{array}$ & $\begin{array}{c}\text { WW005 } \\
2069 E-2 \\
\text { SNLA000352 } \\
06 / 21 / 89\end{array}$ & $\begin{array}{c}\text { WW006 } \\
2069 F \\
\text { SNLA000346 } \\
06 / 22 / 89\end{array}$ \\
\hline \multicolumn{6}{|l|}{ Parameter } \\
\hline Phenols & $<0.05$ & 0.13 & 0.26 & $<0.05$ & 0.40 \\
\hline $\mathrm{Ag}$ & $<0.01$ & $<0.01$ & $<0.01$ & $<0.01$ & 0.02 \\
\hline As & $<0.002$ & $<0.002$ & $<0.002$ & $<0.002$ & $<0.002$ \\
\hline $\mathrm{Ba}$ & 0.42 & 0.40 & 0.09 & 0.41 & 0.45 \\
\hline $\mathrm{Cd}$ & $<0.01$ & $<0.01$ & $<0.01$ & $<0.01$ & $<0.01$ \\
\hline $\mathrm{CN}$ (Total) & $<0.010$ & 0.024 & $<0.010$ & 0.013 & 0.015 \\
\hline $\operatorname{Cr}$ (Total) & 0.03 & $<0.02$ & $<0.02$ & 0.03 & 0.04 \\
\hline $\mathrm{Cu}$ & $<0.02$ & 0.21 & 0.24 & $<0.02$ & 0.05 \\
\hline F (Soluble) & NA & NA & NA & 15.0 & NA \\
\hline $\mathrm{Hg}$ & $<0.0002$ & $<0.0002$ & $<0.0002$ & $<0.0002$ & 0.0004 \\
\hline $\mathrm{Mn}$ & $<0.005$ & 0.008 & $<0.005$ & 0.005 & 0.008 \\
\hline $\mathrm{Ni}$ & $<0.05$ & $<0.05$ & $<0.05$ & $<0.05$ & $<0.05$ \\
\hline$O \& G$ & 8 & 5 & $<4$ & 10 & 10 \\
\hline $\mathrm{Pb}$ & $<0.02$ & $<0.02$ & $<0.02$ & $<0.02$ & $<0.02$ \\
\hline $\mathrm{pH}$ (pH Units) & 8.02 & 7.46 & 7.56 & 8.45 & 7.57 \\
\hline $\mathrm{Se}$ & $<0.002$ & $<0.005$ & $=0.005$ & $<0.002$ & $<0.005$ \\
\hline Temp. $\left({ }^{\circ} \mathrm{C}\right)$ & 26 & 24 & 26 & 27 & 24 \\
\hline Total Metals & $<0.38$ & $<0.52$ & $<0.33$ & $<0.37$ & $<0.42$ \\
\hline TTO & 0.011 & 0.011 & 0.037 & 0.011 & 0.044 \\
\hline $\mathrm{Zn}$ & 0.28 & 0.24 & $<0.02$ & 0.27 & 0.28 \\
\hline
\end{tabular}


conducted in 1989 to identify those areas that would require a permit according to the proposed regulations. Since the regulations are being changed, the study will need to be revised after the new changes are published. Permits for storm water discharge from SNL, Albuquerque, facilities may be required within one year after finalization of the proposed regulations.

\subsubsection{Surface Discharge Programs}

Nonsanitary discharges to surface impoundments for SNL, Albuquerque, is under the authority of the New Mexico Water Quality Control Commission Regulations as implemented by the NMEID Ground Water Bureau.

Storm water from oil storage tank areas and building basements associated with the SNL, Albuquerque, Pulsed Power Development Facilities in Technical Area IV are collected in two lagoons. A Discharge Plan DP-530 was approved for these discharges in March 1988 and amended in December 1989. The approved Discharge Plan, before it was amended, required monthly measurement of water levels and quarterly sampling and analysis for specified groundwater quality parameters. The amended Discharge Plan requires quarterly measurement of water levels and semiannual sampling and analysis. See Table 6-5 for a description of the parameters and sample concentration limits specified in Discharge Plan DP-530. Reports containing the results of the monitoring were submitted quarterly in 1989 to the NMEID, Ground Water Bureau. During 1989, sampling was done in January, March, May, July, September, and November. See Tables 6-7, 6-8, and 6-9, for the water level measurements and the analytical results.

Discharge Plan DP-530 does not 1 ist any limits for sample parameters. Total dissolved solids (TDS) and chloride ion (C1) exceeded the New Mexico State Water Quality Control Commission Standard on several occasions due to ion concentration by evaporation. Organic compounds detected were investigated for possible sources. The possibility of analytical laboratory contamination is high.

\subsection{Air Quality Monitoring}

\section{2 .1 Air Quality}

Ambient air quality is regulated by the Albuquerque/Bernalillo County Air Quality Control Regulations (AQCR). These include the following:

- Ambient Air Quality Standard (regulates As, $\mathrm{Cu}, \mathrm{Zn}, \mathrm{Be}, \mathrm{CO}, \mathrm{HS}, \mathrm{Pb}$, $\mathrm{NO}_{2}, \mathrm{SO}_{2}, \mathrm{TSP}$, hydrocarbons, soiling index and total reduced sulfur)

- AQCR 3: Open Burning

- AQCR 5: Visible Air Contaminants

- AQCR 8: Airborne Particulate Matter

- AQCR 11: Volatile Organic Compounds (VOCs)

- AQCR 12 to 18: Process equipment emissions $\left(\mathrm{NO}_{2}, \mathrm{SO}_{2}\right.$, and particulates) 
Table 6-7. 1989 Water Level Measurements for Lagoons I and II, Technical Area IV, SNL, Albuquerque

\begin{tabular}{|c|c|c|c|c|c|}
\hline \multirow[b]{2}{*}{ Date } & \multicolumn{2}{|c|}{ Lagoon I } & \multicolumn{3}{|c|}{ Lagoon II } \\
\hline & Water Level & \& Full & Water Level & 8 & Full \\
\hline $01 / 20 / 89$ & $6 \mathrm{ft.} 6 \mathrm{in}$. & 61 & $0 \mathrm{ft} .0 \mathrm{in}$. & & 0 \\
\hline $02 / 15 / 89$ & $6 \mathrm{ft} .5 \mathrm{in}$. & 60 & $0 \mathrm{ft} .6 \mathrm{in.}$ & & 3 \\
\hline $03 / 14 / 89$ & $5 \mathrm{ft} .8 \mathrm{in.}$ & 54 & $2 \mathrm{ft.} 0 \mathrm{in.}$ & & 10 \\
\hline $04 / 20 / 89$ & $5 \mathrm{ft} .2 \mathrm{in.}$ & 48 & $1 \mathrm{ft} .6 \mathrm{in.}$ & & 8 \\
\hline $05 / 18 / 89$ & $4 \mathrm{ft} .8 \mathrm{in.}$ & 4] & $\star$ & & $*$ \\
\hline $06 / 27 / 89$ & $4 \mathrm{ft} .0 \mathrm{in.}$ & 36 & $3 \mathrm{ft} .6 \mathrm{in.}$ & & 20 \\
\hline $07 / 19 / 89$ & $3 \mathrm{ft} .7 \mathrm{in.}$ & 32 & $2 \mathrm{ft} .8 \mathrm{in.}$ & & 13 \\
\hline $08 / 11 / 89$ & $4 \mathrm{ft.} 2 \mathrm{in.}$ & 38 & $1 \mathrm{ft.} 2 \mathrm{in.}$ & & 6 \\
\hline $09 / 21 / 89$ & $4 \mathrm{ft} .2 \mathrm{in.}$ & 38 & $1 \mathrm{ft} .6 \mathrm{in.}$ & & 8 \\
\hline $10 / 13 / 89$ & $4 \mathrm{ft} .9 .5 \mathrm{in.}$ & 44 & $1 \mathrm{ft.} 5 \mathrm{in.}$ & & 7 \\
\hline $11 / 15 / 89$ & $4 \mathrm{ft} .8 \mathrm{in}$. & 41 & $0 \mathrm{ft} .0 \mathrm{in}$. & & 0 \\
\hline $12 / 18 / 89$ & $4 \mathrm{ft} .9 \mathrm{in.}$ & 44 & $0 \mathrm{ft} .0 \mathrm{in}$. & & 0 \\
\hline $\begin{array}{l}\text { *The wat } \\
\text { May } 18\end{array}$ & in lagoon II & inadve & not measured & the & \\
\hline
\end{tabular}

- AQCR 20: Authority-to-Construct Perinit

- AQCR 22: Registration of Air Contaminant Sources

- AQCR 29: Prevention of Significant Deterioration

- AQCR 30: New Source Performance Standards

- AQCR 31: NESHAP and others.

The Air Pollution Control Division under the Albuquerque Environmental Health Department has set up several. ambient air sampling stations throughout the city including the area near SNL, Albuquerque, to monitor TSP, ozone, $\mathrm{PM}_{10}, \mathrm{CO}$, and $\mathrm{NO}_{\mathrm{x}}$. The results were published periodically in the local newspaper.

\subsubsection{Airborne Emissions and Permits}

Several sources at $\mathrm{SNL}$, Albuquerque, emit air pollutants that are regulated by the AQCR. The emissions from these sources are described below:

- Topsoil Disturbance

Prior to any disturbance of the soil, SNL, Albuquerque, or its contractor will apply for a Topsoil Disturbance Permit and implement a plan for controlling dust emissions generated by conctruction activities according to the requitement of AQCR 0 , 
Table 6-8. 1989 Major Cations, Anions, and TDS for Lagoons I and II, Technical Area IV, SNL, Albuquerque*

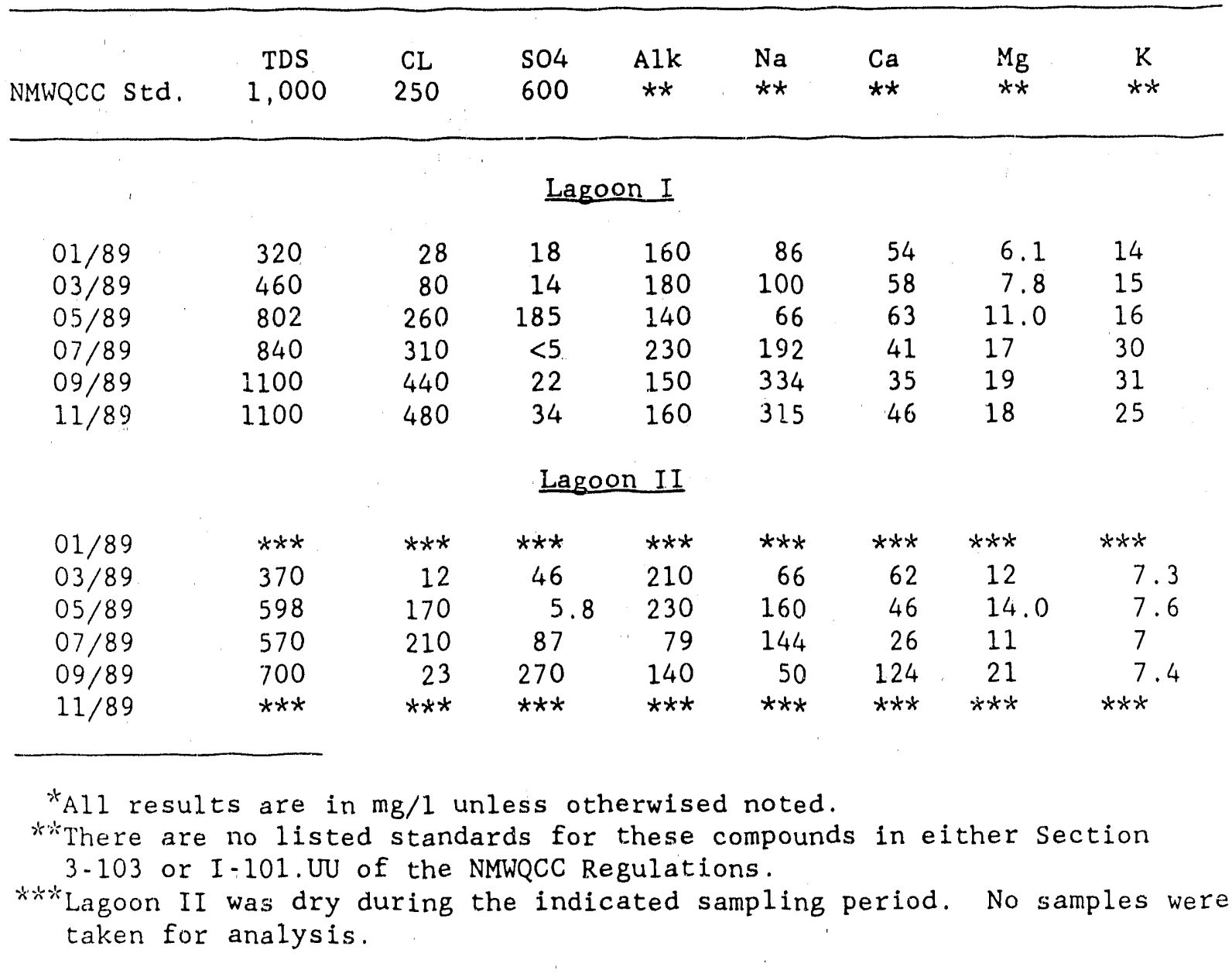

Airborne Particulate Matter. These mitigation measures include watering; phasing of construction; rescheduling of construction during windy period; limitations on vehicle access and vehicle speed; and use of dust palliatives where watering is ineffective.

- Open Burning

The Thermal Test and Analysis Division (at Coyote and Lurance Canyon Burn Sites) and the Thermal Treatment Facility (in Area III) conducted several burn tests during 1989. Open Burn permits were obtained from the City of Albuquerque prior to each scheduled burn test according to the requirement of AQCR 3 (Open Burning). 
Table 6-9. 1989 Organic Compounds Detected for Lagoons I and II, Technical Area IV, SNL, Albuquerque*

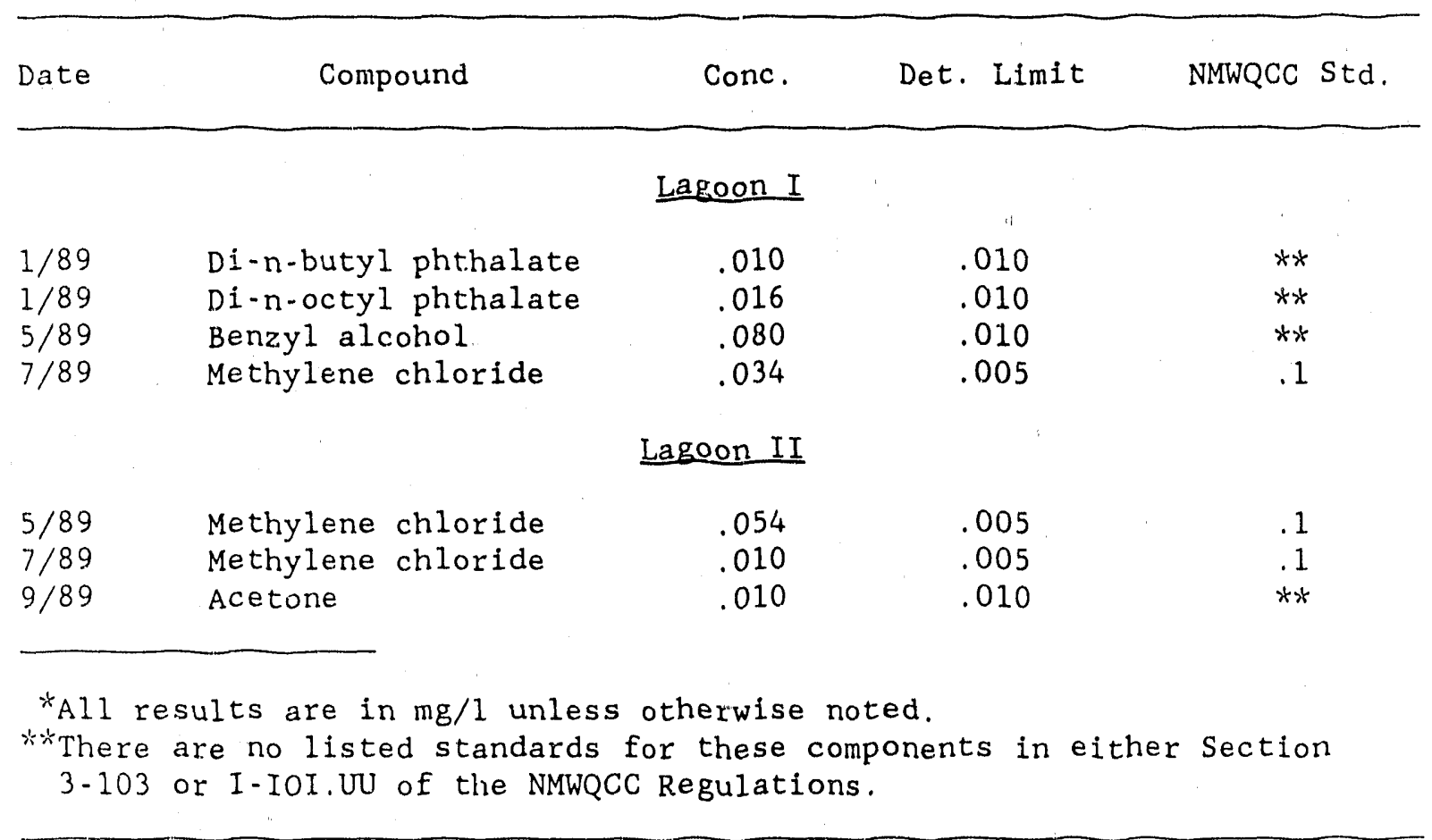

- Beryllium Machining Operation

The Building 869-Toxic Machine Shop occasionally conducts machining of beryllium-containing materials. The operation is regulated by $A Q C R \quad 31$ (NESHAP) standard for beryllium. Exhaust air from the operation passes through air-pollution control equipment before exiting from a stack. The shop uses HEPA (high-efficiency particleattenuation) filters to control emissions, with a removal efficiency of more than 99 percent. Emission tests conducted during December 1989 demonstrated that the actual beryllium emission (less than 1.8 $\times 10^{-7} \mathrm{lb} / \mathrm{hr}$ ) meets AQCR 31 limits of $9.2 \times 10^{-4} \mathrm{lb} / \mathrm{hr}$ or $10 \mathrm{gm} / 24$ hr specified in 40 CFR 61.32 .

- Steam Generators

SNL, Albuquerque, proposed a modernization plan of the steam producing facility in January 1989. The more efficient controls of the new plant should produce smoother plant operation and result in a decrease of average contaminant emissions. Therefore, a confirmation was obtained from the City stating that no new source permit was required. 


\subsubsection{Emission Inventory}

At the beginning of October 1989, SNL, Albuquerque, started the ES\&H compliance initiative effort. As part of the effort, the Environmental Programs Department initiated the Hazardous Air Emission Inventory effort to survey air emissions within SNL, Albuquerque. This air emission inventory is expected to finish by May 1990. The inventory will include a list of significant exhausted hazardous chemicals, estimated quantities of emissions, and stack information including associated control equipment. 


\section{CHAPTER 7 GROUNDWATER MONITORING}

\subsection{Review of the Groundwater Monitoring Program}

The Groundwater Monitoring Program activities conducted by SNL, Albuquerque, during 1989 included measuring the water-level elevations of monitor wells to identify the groundwater flow patterns in the region and sampling the groundwater at the CWL for the purpose of establishing the background groundwater quality.

\section{Chemical Waste Landfil1 (CWL).}

Groundwater monitoring at the CWL (Figure 7-1a) has been an operational program since 1985. The groundwater monitoring program was developed to comply with the groundwater monitoring requirements of RCRA and DOE 5400.1. The monitor well system at the CWL consists of a network of nine groundwater monitor wells (Figure 7-1b).

Five groundwater monitoring wells (MW-1, MW-2, MW-3, BW-1, and BW-2), were installed at the CWL during the summer of 1985 using a mud rotary drilling method. These wells were completed at various vertical depths within the aquifer, with screened intervals ranging from 70 to $460 \mathrm{ft}$ in length. MW- 1 is presently unusable for monitoring because it was later plugged by a bailer. In 1988, four additional wells (BW-3, MW-1A, MW-2A, MW-3A) were installed at the CWL using air rotary casing hammer techniques. The 1988 wells have 20 -ft screened intervals located such that approximately $15 \mathrm{ft}$ of screen is below the water table.

The shallow monitor wells are currently sampled for detection monitoring requirements (MW-1A, MW-2A, MW-3A, BW-3). Four quarters of background data have been completed, and the semiannual sampling will begin in 1990. To date, contamination has not been identified in the groundwater beneath the landfill. Detection monitoring is expected to continue, with statistical evaluations of groundwater quality data utilized to assess changes in groundwater quality.

\section{Mixed Waste Landfi11 (MWL)}

This program was initiated in 1989 with the completion of four groundwater monitoring wells (Figure 7-2). The program will also be required to meet the groundwater monitoring requirements of RCRA. Planned activities include the development of sampling and analytical protocols and assessing the quality of the groundwater beneath the site.

\subsection{Background Setting}

The following section expands on the information given in Chapter 2 and provides a description of the geology, hydrology, and geographic setting of the SNL; Albuguerque, area with particular emphasis on the chl site. 


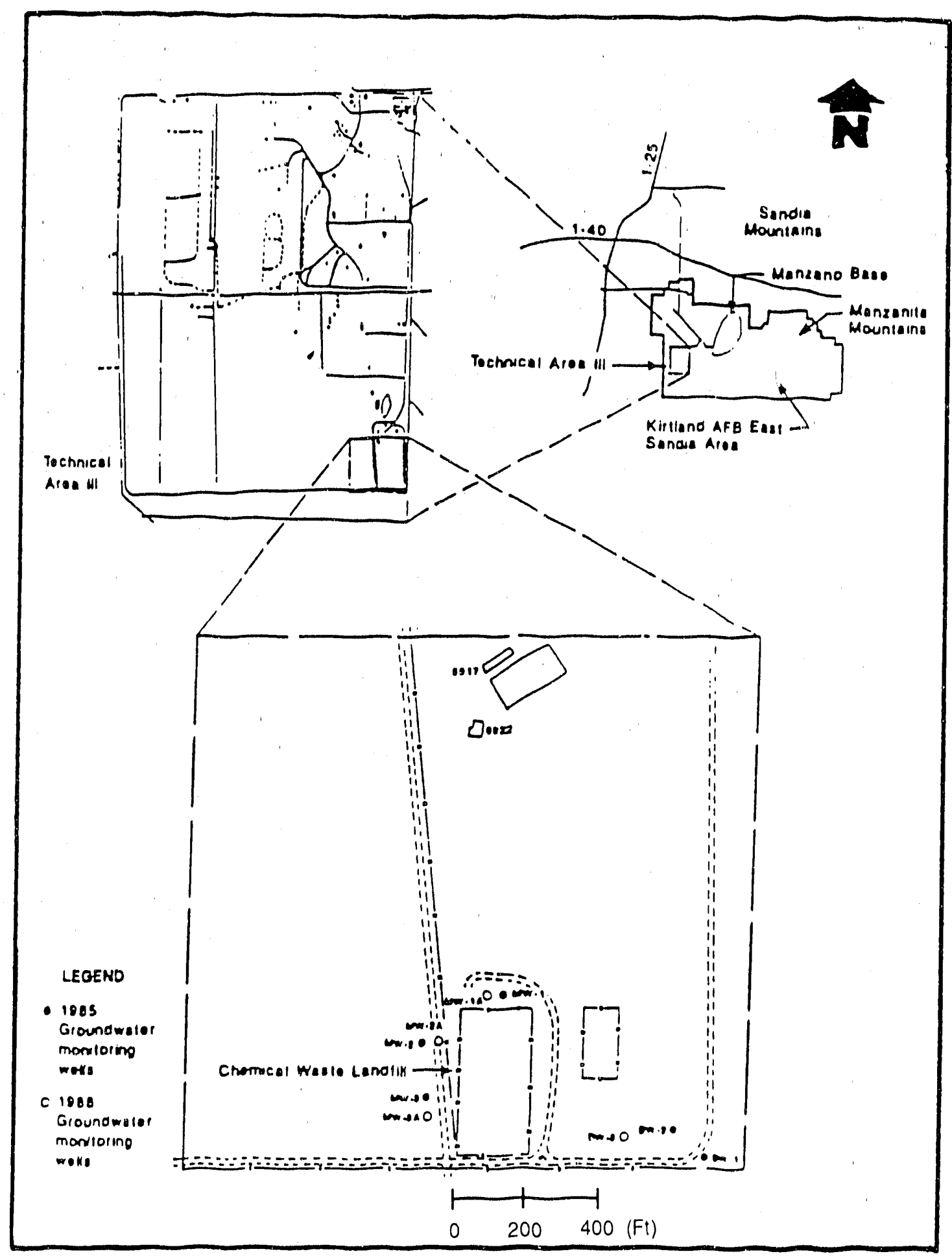

Figure 7-1a. Location of Chemical Waste Landfill (CWL), Technical Area III 


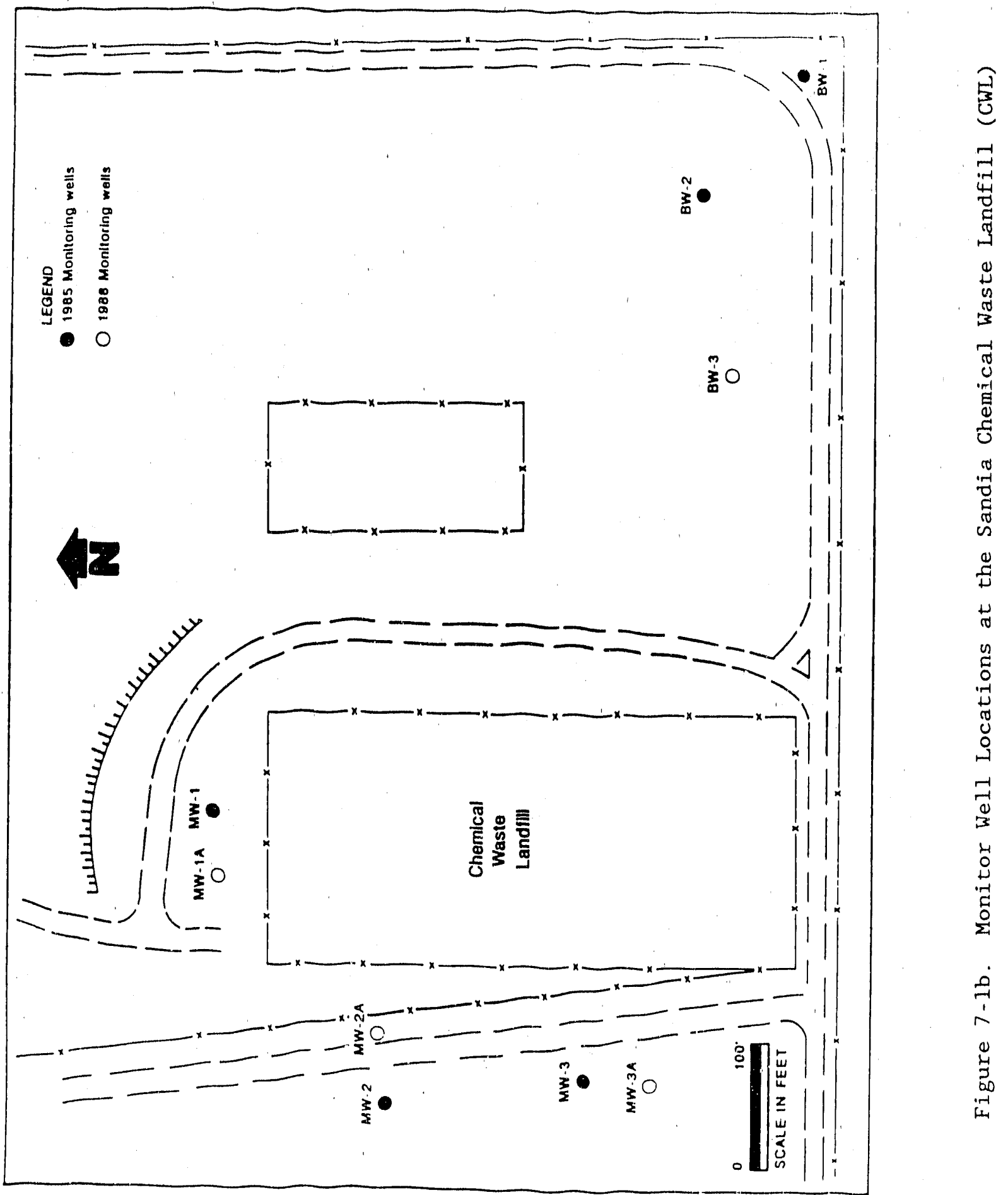




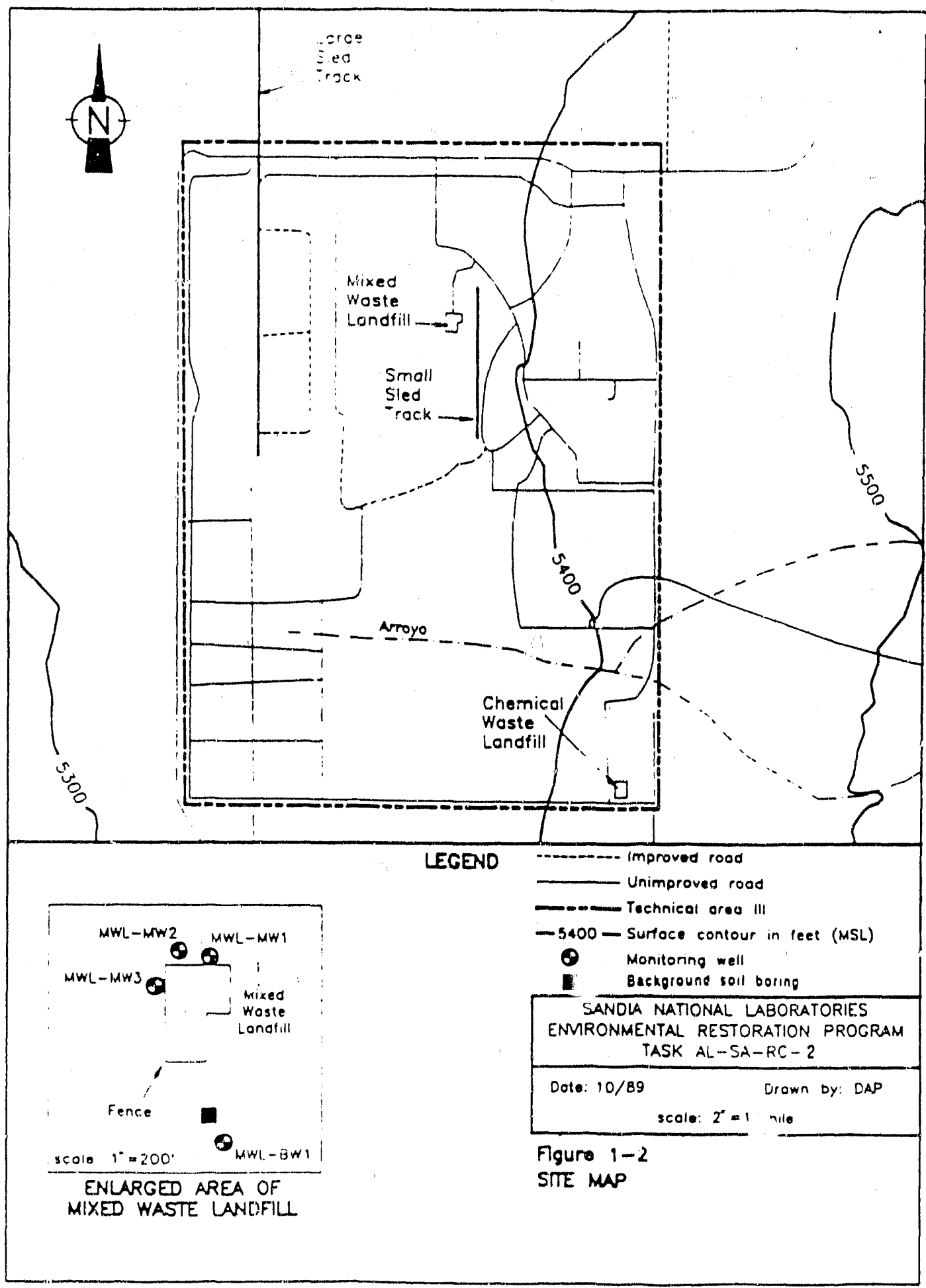

Figure 7.?. Monitori.ig Well Locations at the Mixed Waste Landfill (MWL) 


\subsubsection{Geographic Setting}

SNL, Albuquerque, is located near the east-central edge of the AlbuquerqueBelen Basin within the Rio Grande rift zone, on the southeast side of the City of Albuquerque, New Mexico, in Bernalillo County (Figure 7-3). The facilities of SNL, Albuquerque, are within the boundaries of KAFB. Within SNL, Albuquerque, there are five designated technical areas. The area which contains the CWL is Technical Area III. The CWL is approximately 4 $\mathrm{mi}$ south of the nearest drinking water supply well and at least $3 \mathrm{mi}$ from any natural groundwater discharge point.

The climate of the region is semiarid. Average annual precipitation is approximately 8 in. Most of the precipitation occurs as thunderstorms diring late summer to early fall. A fair amount of snowfall also occurs during the winter months. Average daytime summer temperatures are approximately $90^{\circ} \mathrm{F}$, while winter daily temperatures are approximately $50^{\circ} \mathrm{F}$.

\subsubsection{Geology}

Studies of the regional geology of the Albuquerque Basin have been presented by Kelley (1977) and Bryan (1938). The following discussion relies heavily on information from these studies.

The Aibuquerque-Belen Basin, which is one of a north-south trending line of basins that make up the Rio Grande Rift zone. The Rio Grande River flows southward through the middle of the basin from White Rock Canyon on the north $(5,300-\mathrm{ft}$ altitude) to the Rio Salado junction on the south $(4,700-\mathrm{ft}$ altitude). On the east and west, the basin is bounded by uplifted fault blocks. The Sandia, Manzanita, and Manzano Mountains are uplifted on the eastern boundary. The western side of the basin is bounded by the Lucero uplift with the Ladron Mountains on the south with little physiographic relief on the northwest wide of the basin (Figure 7-3). At SNL, Albuquerque, the Tijeras and Hubbel springs Faults run roughly north-south along the west face of the sandia Mountains. The faults create a series of stepped offsets, with general downward movement toward the west and the east (SAIC, 1985), ad therefore depth to groundwater is less to the east of the fault system han to the west.

During the Miocene and Pliocene, the Albuquerque Basin filled with a thick (up to $12,000 \mathrm{ft}$ ) sequence of sediments er ded from the surrounding highlands. This sequence of sediments, called the Santa Fe Group, thins toward the edges of the basin and is truncated at the bounding uplifts. Santa Fe Group sediments are overlain in places by pliocene Ortiz gravel deposics and Rio Grande River fluvial deposits, and are interbedded with Tertiary and Quaternary basalts and pyroclastics (Bjorklund and Maxwel1, 1961).

Basin fill alluvial fans of the Santa Fe Group consist of channels, debris; flows, flood plain deposits, and aeoliall drposits. According to Reineck and singh (1975), these general types of sediments are composed of coarse, poorly-sorted, imnature clastics ranging in size from clay to boulders. 


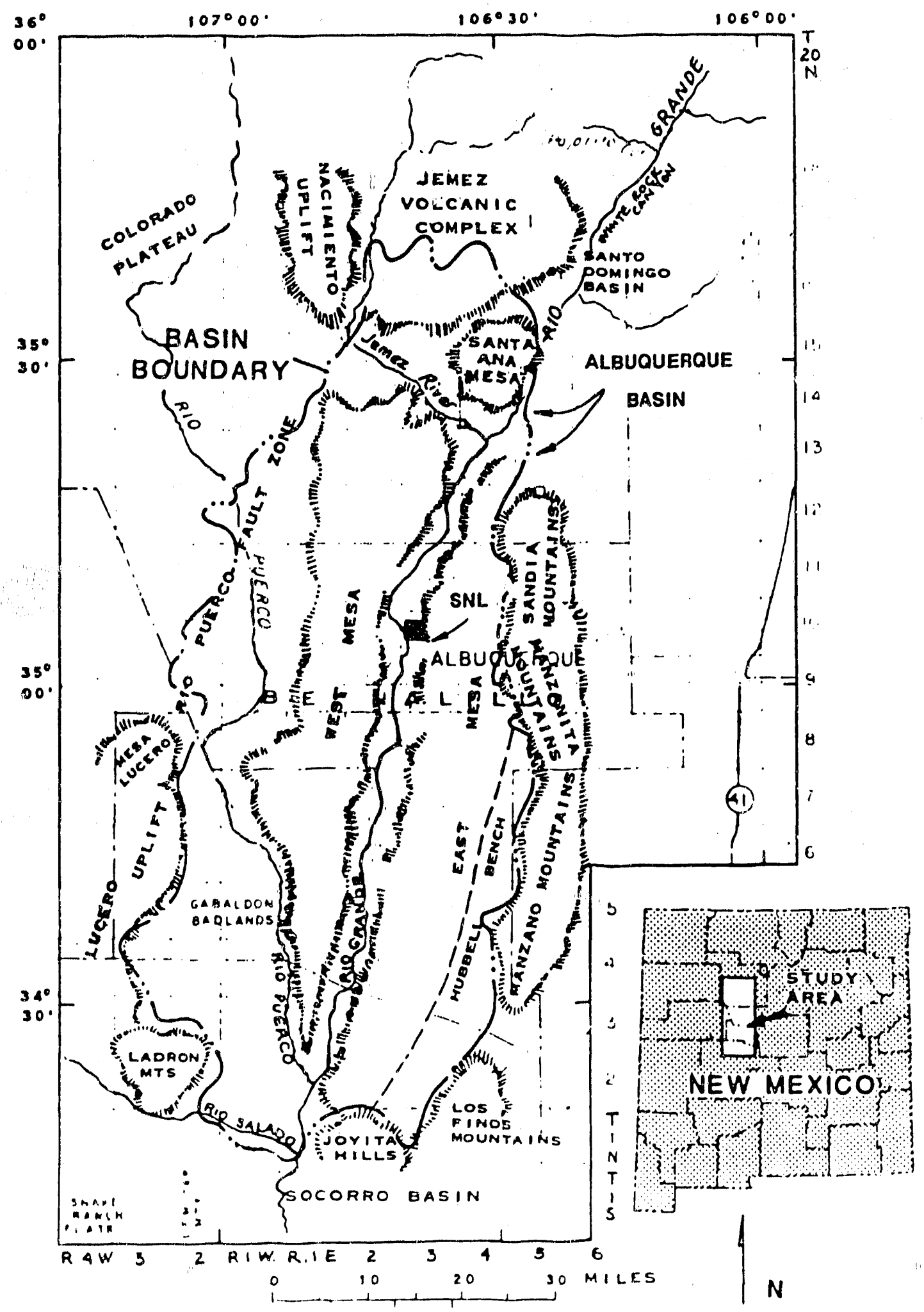

Figure 7-3. The Location of SNL in the Albuquerque-Belen Basin 
Stratification can be muderately well developed, and some graded bedding may occur. Beds can vary in thickness from a $f e w ~ c m$ to several $\mathrm{m}$. Much of the bedding is lenticular with limited aerial extent; however, channel beds can extend downdip for long distances, and flood deposits can lay thin sheets of fine sediments over significant areas. Caliche layers are commoniy formed on subaerially exposed surfaces.

Based on the regional geologic setting of SNL, Albuquerque, any of the depositional sequences discussed above could be present. To date, analysis of sediments collected during emplacement of the SNL, Albuquerque, monitor wells has shown little correlation between wells. Sediments collected have been unconsolidated and semiconsolidated cobbles, sands, and gravels with inclusions of silt and clay lenses intermixed with sand. Lithologic logs from the installation of the nine monitoring wells at the CWL have been presented by IT Corporation (1985) and the DOE RCRA Groundwater Monitoring Plan (DOE, 1988). Lithologic logs from the installation of the monitor wells at the MWL are described by Ecology and Environment, Inc. (1989).

\subsubsection{Hydrology}

The regional hydrologic system of the SNL, Albuquerque, area is controlled by the processes which occur in the Albuquerque-Belen Basin. The Albuquerque-Belen Basin is approximately $100 \mathrm{mi}$ long and 20 to $40 \mathrm{mi}$ wide. The Rio Grande River is the main drainage in the basin flowing south, and the Jemez River, Rio Puerco, and the Rio Saladc are major tributaries to the basin (Figure 7-3). The Albuquerque-Belen Basin is hydraulicall., connected to the Santo Domingo Basin to the north and the Socorro Basin to the south according to a report by Anderholm (1988).

In general, the Sandia and Manzano Mountains act as recharge zones for deep, regional saturated flow. Prior to extensive development in the City of Albuquerque and KAFB, the apparent groundwater flow direction in the Sill, Albuquerque, area was to the west or southwest, as presented by Bjorklund and Maxwell (1961). South of KAFB, the ambient direction of flow was to the southwest.

Municipal pumping and its subsequent effect of lowering the water table elevation in the Albuquerque area is discussed by Reeder, Bjorklund, and Dinwiddie (1967) and Kues (1987). The regional elevation of the water table in the SNL, Albuquerque, area in June 1989 is depicted in Figure 7-4. The KAFB production wells have a large effect on the hydraulic gradient in the area, creating a cone of depression in the groundwater surface elevation in the northern portion of the region. It is important to note that where there is a lack of data (i.e., west of Technical Area III) there is uncertainty in the potentiometric surface.

At the CWL, the water table is located approximately $480 \mathrm{ft}$ below the land surface. According to water level contour maps, the apparent direction of groundwater flow at the CWL is to the northwest, assuming steady-state clow conditions are present ain that hie dyuifer is homogeneous and isotropic. 


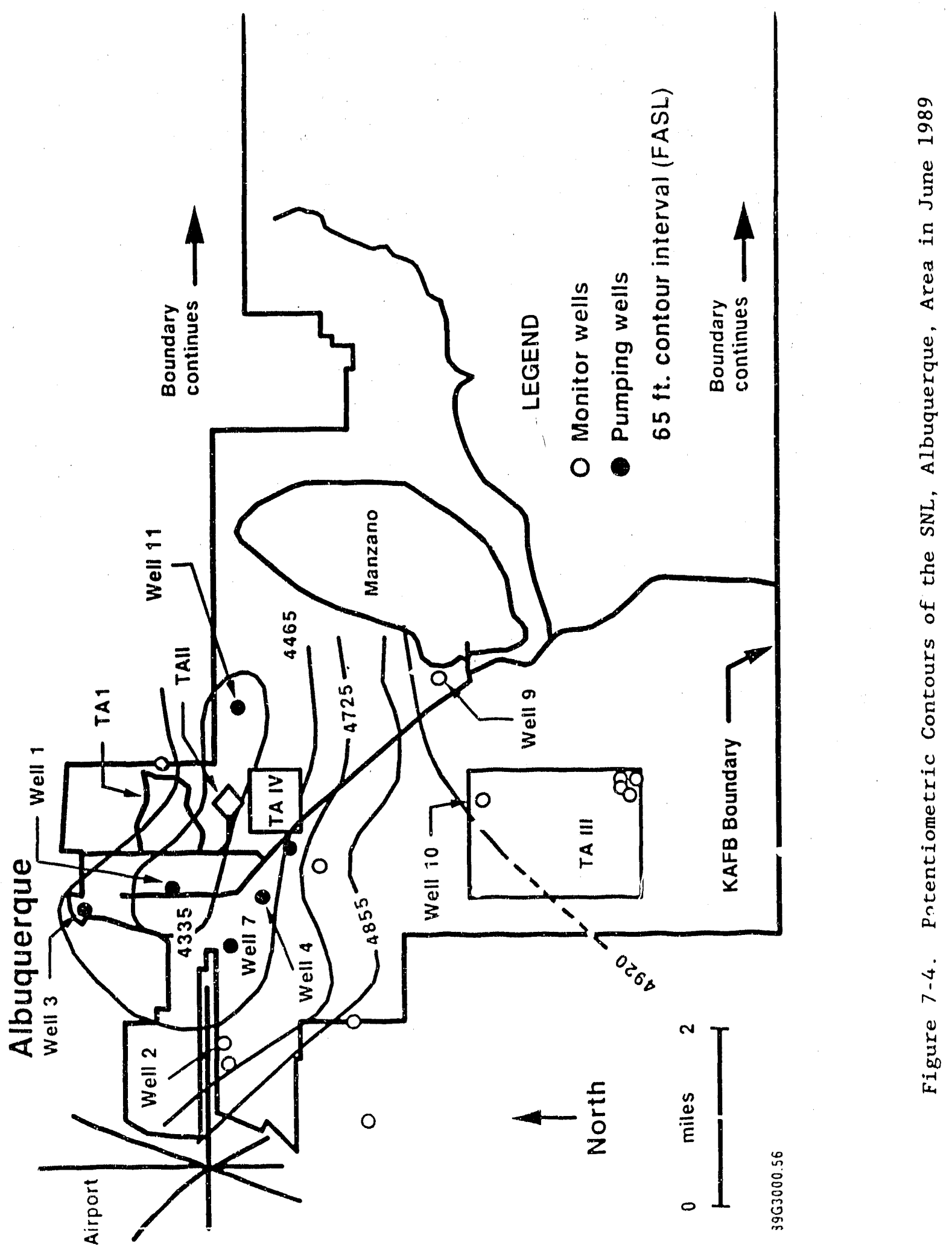


In addition, it appears that the KAFB production well pumping may affect the water-1evel figtuations observed in the CWL monitor wells.

\section{$7.3 \quad 1989$ J 6 wnduater Monitoring Activities}

Groundwater monitoring activities conducted by SNL, Albuquerque, during 1989 included measuring the water-level elevations of monitor wells in the SNL, Albuquerque, area and sampling the groundwater in "the" CWL monitor wells to establish the background groundwater quality. The following sections describe these activities and results for the calendar year 1989.

\subsubsection{Water-Level Measurements}

The elevation of the groundwater was measured in the eight currently monitored CWL wells prior to each sampling event to assure that the monitor well network continued to consist of at least one upgradient well and three downgradient wells. To supplement the local groundwater elevation data from the CWL and determine the general hydraulic gradient in the SNL, Albuquerque, area, the groundwater surface elevation was measured in all of the SNL, Albuquexque, monitor wells and sereral other monitor wells on a monthly basis beginning in May 1989. The additional monitor welis which were measured by SNL, Albuquerque, include the two NMEID monitor wells in Tijeras Arroyo, the two U.S. Air Force landfill monitor wells, and the KAFB wells 9 and 10 (Figure 7-5). Tables 7-1, 7-2, and 7-3 present the groundwater elevation data collected by SNL, Albuquerque, in 198? for CWL wells, MW Landfill wells and KAFB wells, respectively.

Records of the KAFB ploduction well static water levels wiere obtained from the U.S. Air Force. The U.S. Geological Survey provided dala from the City' of Albuquerque monitor well located east of Technical Area I (near the Eubank Gate) and KAFB well 5. These data were included in the SNL, Albuquerque, analysis.

\subsubsection{Groundwater Sampling}

The groundwater was sampled at the CWL to establish the background groundwater quality conditions in the monitor wells screened at the water table (BW-3, MW-1A, MW-2A, MW-3A). The first quarterly sampling took place in December 1988. During the calender year of 1989, the final three background groundwater sampiing events were perform in March, June, and September. During the June 1989 sampling period, the sample holding tirnes for total coliform bacteria, Total Organic Halogen (TOX), and nitrate were exceeded, and the equipment blank had slight traces of chromium. Resampling for these four constituents was conducted during the September 1989 quarterly sampling event. Subsequently, an additional sampling period took place in January 1990, to provide the fourth set of total chromium, total coliform bacteria, Tox, and nitrate data. The results of all four quarters of background groundwater sampling and the supplemental sampiing are reported in section 7.3.4. 


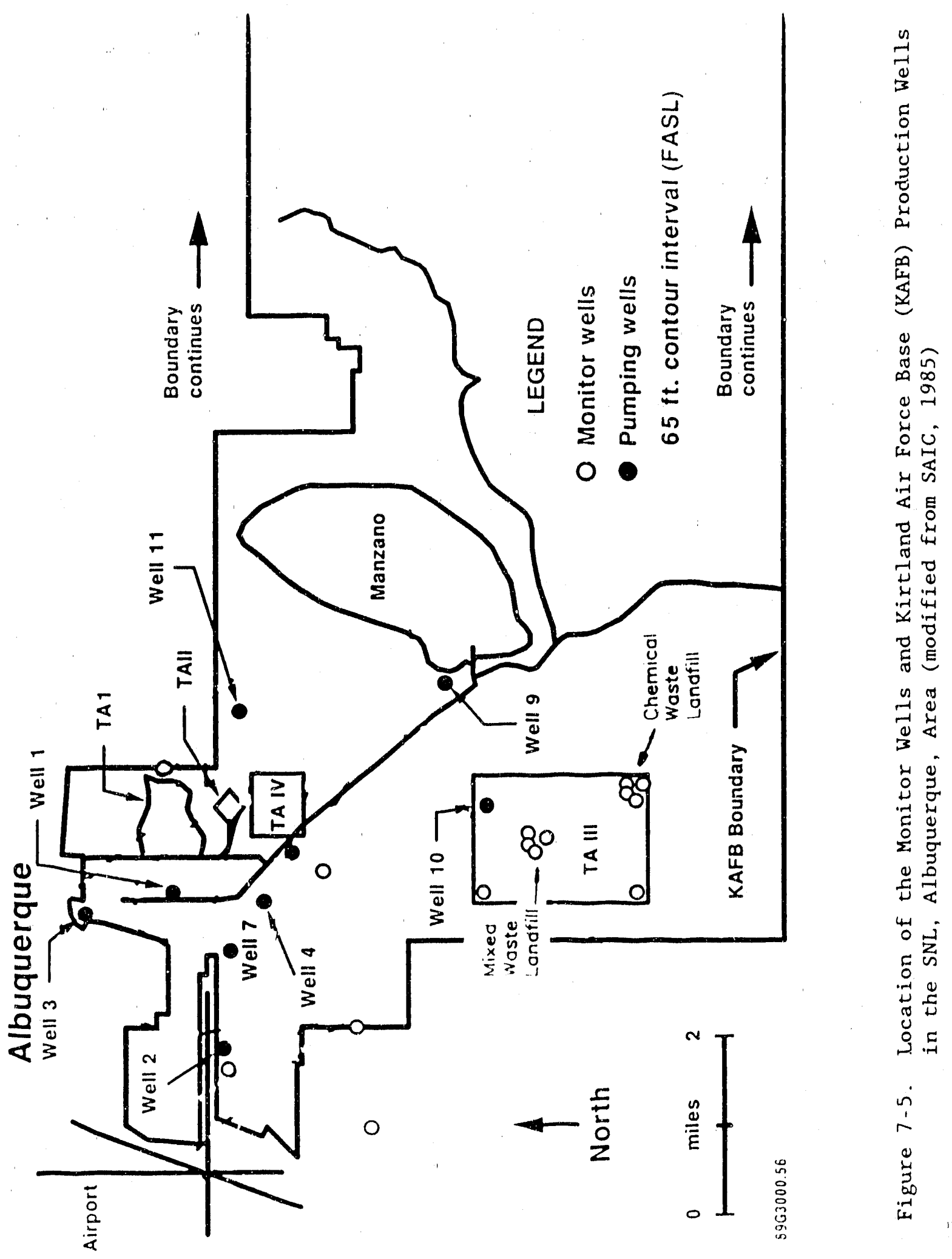




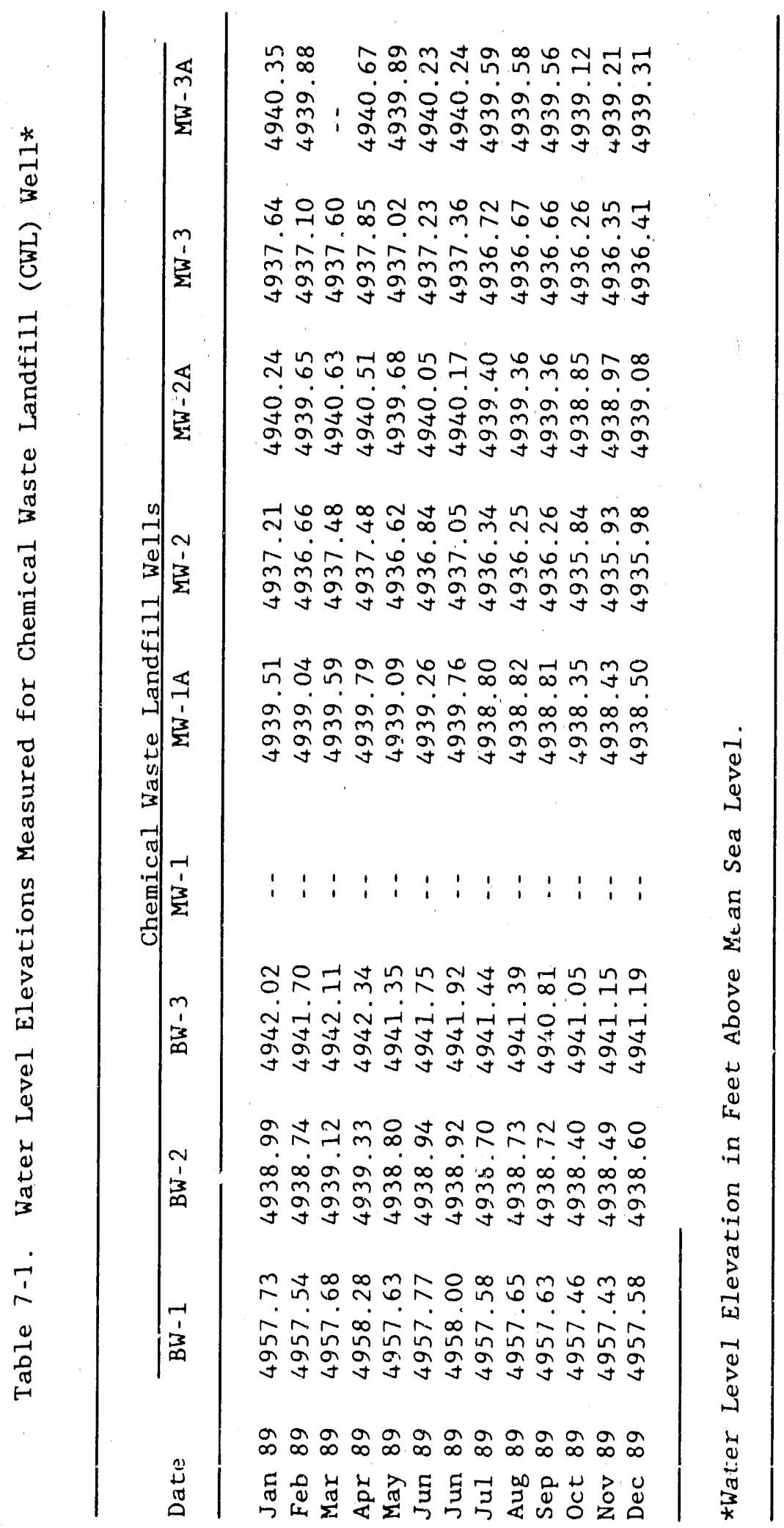


Table 7-2. Water Level Elevations Measured for Mixed Waste Landfill (MWL) Wells*

\begin{tabular}{|c|c|c|c|c|}
\hline \multirow[b]{2}{*}{ Date } & \multicolumn{4}{|c|}{ MWL Wells } \\
\hline & MWL - MW]. & MWL-MW2 & MWL-MW3 & MWL-BW1 \\
\hline $\mathrm{Jan} 89$ & 4924.59 & $\cdots$ & $\cdots$ & $\cdots$ \\
\hline Feb 89 & $\cdots$ & $\cdots$ & - & - \\
\hline Mar 89 & 4927.46 & - & 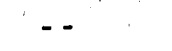 & $\cdots$ \\
\hline Apr 89 & 4925.13 & $\cdots$ & - - & - \\
\hline May 89 & 4924.56 & $\cdots$ & - & $\cdots$ \\
\hline Jun 89 & 4924.70 & $\cdots$ & - & - \\
\hline Jun 89 & - - & $\cdots$ & $\cdots$ & $\cdots$ \\
\hline Jul 89 & 4924.12 & $\therefore$ & $\ldots$ & $\cdots$ \\
\hline Aug 89 & 4924.13 & $\cdots$ & $\ldots$ & $\cdots$ \\
\hline Sep 89 & 4924.11 & - & $\ldots$ & $\ldots$ \\
\hline Oct 89 & 4923.62 & - - & - - & - \\
\hline Nov 89 & 4923.78 & 4923.86 & 4920.14 & 4923.62 \\
\hline Dec 89 & 4923.89 & 4924.01 & $\cdots$ & 4923.72 \\
\hline
\end{tabular}

*Water Level Elevation in Feet Above Mean Sea Level

- Not measured. Note that MWL-MW2, MWL-MW3, and MW1-BW1 were not installed until late summer 1989.

\subsubsection{Sampling Procedures and Methods}

The specific sampling and analysis, protocols for each constituent of interest are specified in the Sampling and Analysis Plan (SNL, 1988). The procedure for the collection of groundwater samples includes (1) monitoring the well head atmosphere for the presence of organic vapors which may indicate the presence of nonaqueous phase liquids (NAPL), (2) measuring the groundwater elevation and total depth of each well, (3) purging the well of three well volumes, (4) collecting the desired groundwater sample in specified containers provided by the analytical laboratory, and (5) sending the samples to the analytical laboratory for analysis.

Specific details pertaining to each quarterly background groundwater sampling event are described in the quarterly groundwater sampling reports and the supplemental groundwater sampling report (IT Corporation, 1989a; 1989b; 1989c). These reports contain summary tables, raw field and laboratory data, QA-QC results, and descriptions of the analytical methods employed by the laboratories. 


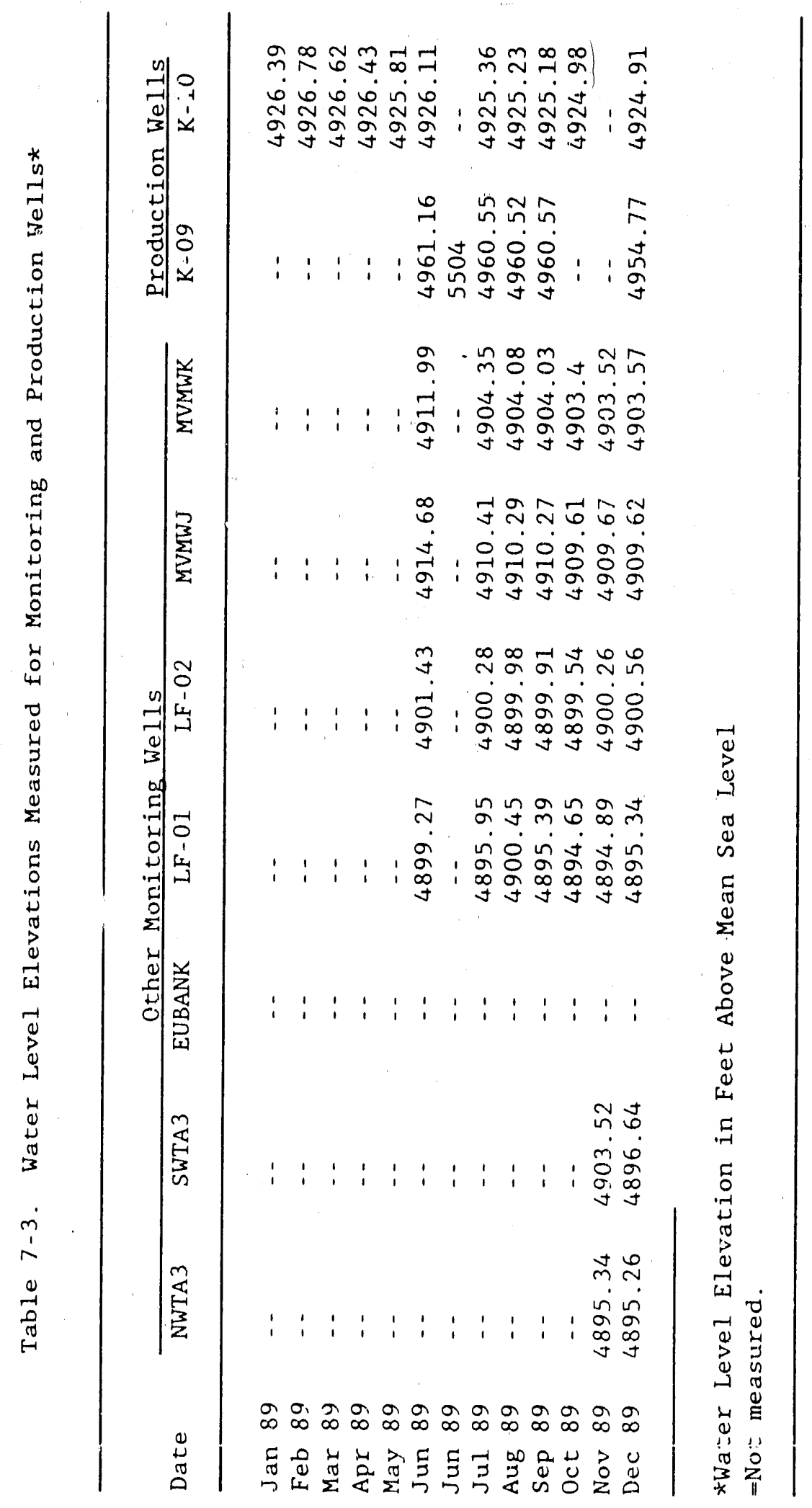




\subsubsection{Water Quality Background Monitoring Data}

The background concentrations of groundwater contamination indicator parameters ( $\mathrm{pH}$, specific conductance, TOX, Total Organic Carbon (TOC) are presented in Appendix F, F-7a to F-7d. Both the field and laboratory results are included for $\mathrm{pH}$ and specific conductance. If the parameter was not detected, the reported value is equal to half of the detection limit as recommended by the EPA (1986). The arithmetic mean and variance of all replicate samples have been calculated (Appendix F, Tables F-7a to F-7d). The TOX data from January 1990 was used in place of the June 1989 TOX data, which was not valid because the sample holding time was exceeded.

Results of background concentrations of the groundwater quality indicator parameters (chloride, iron, manganese, phenols, sodium, and sulfate) are presented in Appendix F, Tables F-8a to F-8d. Both total (unfiltered) and dissolved (filtered) metal concentrations were measured.

Tables F-9a through F-9d in Appendix F show the metal constituents of the background concentrations of the Appendix III EPA interim primary drinking water supply parameters. Both total (unfiltered) and dissolved (filtered) metal concentrations were measured. All of the measured constituents were below the drinking water standard (MCL) with the exception of total chromium in the unfiltered samples.

None of the dissolved chromium samples had concentrations above the MCL of $0.05 \mathrm{mg} / 1$; however, analysis of $\mathrm{BW}-3, \mathrm{MW}-1 \mathrm{~A}$, and $\mathrm{MW}-2 \mathrm{~A}$ indicated total chromium concentrations above the MCL during three separate sampling events (Appendix F, Tables F-9a to F-9d). In December 1988, the total chromium concentration in MW-2A was determined to be $0.06 \mathrm{mg} / 1$. The turbidity was high in $\mathrm{MW}-2 \mathrm{~A}$ during this time relative to the other monitor wells, and perhaps the high total chromium was due to the high sample turbidity.

In June 1989, the total chromium analysis indicated a concentration of $0.06 \mathrm{mg} / 1$. in $\mathrm{MW} \cdot 1 \mathrm{~A}$. This may have been due to the equipment blank concentration of $0.03 \mathrm{mg} / 1$. The inductively-coupled plasma mass spectrometry (ICP) analytical method (detection limit of $0.01 \mathrm{mg} / 1$ ) was used for the first three quarters of sampling.

In September 1989, the ICP method and a more sensitive graphite furnace atomic adsorption (GFAA) technique (detection limit of $0.001 \mathrm{mg} / 1$ ) were used. The results of two methods were consistent, with the exception of BW-3 where the ICP indicated no detection and the GFAA results showed a concentration of $0.068 \mathrm{mg} / 1$. These results supported the decision to analyze chromium by using the GFAA method for future sampling events.

The high total chromium concentrations detected in BW-3 may be due to particulate larger than 0.45 microns present in the alluvial material at the CWL. None of the dissolved chromium concentrations are above the detection limit of $0.001 \mathrm{mg} / 1$. Particulate (greater than 45 microns) obtained from filtering selected CWL groundwater samples were examined by 
scanning electron microscopy. The electron microscopy results indicate that chromium is present in the form of small particulate matter (less than 1 micron) as discrete particles randomly dispersed throughout the sample. Additionally, X-ray fluorescence (XRF) and direct current plasma (DCP) emission spectroscopy analysis results of alluvial core samples collected near the CWL indicate the natural background concentrations of the sediments ranges from approximately 10 to $30 \mathrm{ppm} / \mathrm{kg}$-bulk material.

Tables F-10a to F-10d in Appendix F contain the other Appendix $C$ constituents. The concentrations of these constituents were consistently below the MCL except gross alpha, total coliform bacteria, and turbidity.

Gross alpha activity equalled or exceeded the drinking water standard of $15 \mathrm{pCi} / 1$ in all four wells during the background sampling (Appendix $\mathrm{F}$, Tables F-10a to F-10d). During June 1989, additional samples were collected to investigate the source of the gross alpha activity at the CWL. As shown in Appendix F, Table F-11, 72 to 95 percent of the alpha activity is attributable to uranium isotopes. The mass distribution of uranium isotopes compared with natural (i.e., equilibrium) mass distributions are shown in Appendix F, Table F-12. The mass distribution of uranium in the groundwater samples approaches the natural occurrence, suggesting that uranium, and the associated alpha activity in groundwater samples at the CWL are naturally occurring.

The concentration of total coliform bacteria was unknown in at least one of the four wells during each quarterly sampling event (Appendix $F$, Tables F-10a to F-10d). This is because the total coliform analysis could not be performed for some of the samples due to a high noncoliform bacteria population (i.e., too numerous to count). There is no particular pattern to the occurrence of high noncoliform bactaria concentrations. In December 1988, the field blank had high noncoliform concentrations, and in March 1989, the field blank and the equi.pment blank had high noncoliform bacteria concentrations. Thus, it appears that the high noncoliform bacteria concentrations detected in the monitor wells may actually be due to the field sampling method, a contaminated container, or the laboratory analysis procedures.

The turbidity exceeded the drinking water standard of 1 Nephelometric Turbidity Unit (NTU) for about half of the samples collected in each of the wells at some time (Appendix F, Tables F-10a to F-10d). However, the standard for monitor well analysis of 5 NTU (EPA, September 1986) was only exceeded in BW-3 during the first quarter of sampling in December 1988 . Subsequent sampling events show turbidity values mainly between 0.5 and 2.5 N'rU.

\subsection{Summary}

This chapter described the groundwater monitoring activities conducted at SNL, Albuquerque, during the calender year 1989. The groundwater at the CWL was sampled to determine the background groundwater quality conditions. The groundwater surfare elevation was evaluated by measuring the water 
level at monitor wells in the SNL, Albuquerque, area. Additionally, new monitor wells were installed for the purpose of better determining the water table elevation contours in the area.

The apparent groundwater flow direction at the CWL is to the northwest. Potentiometric surface contour maps of the CWL indicate that the groundwater monitor network satisfies the requirements of 40 CFR 265.91; 1.e., the monitor wells are located such that there is one upgradient well $(B W-3)$ and three downgradient wells (MW-1A, MW-2A, MW-3A).

The specific sampling and analysis protocols used for the collection of groundwarer samples are specifled in the Sampling and Analysis Plan (SNL, Albuquerque 1988). Background groundwater quality conditions were established at the CWL for the Appendix C drinking water supply parameters, contamination indicator parameters, and groundwater quality parameters. Although the drinking water standards were exceeded for total chromium, gross $\alpha$, and turbidity, there is no indication that the groundwater has been contaminated due to a release from the CWL. The high total chromium concentrations may be due to high sample turbidity or particulate matter present in the groundwater. The high gross a activity has been attributed to uranium content, of which the distribution approaches naturally occurring conditions in groundwater. Only one of the turbidity measurements was above the EPA recommendation of 5 NTU, and that was during the first sampling period. In addition, for some of the samples, it was not possible to measure the concentration of total coliform bacteria due to high levels of noncoliform bacteria. The presence of high noncoliform bacteria concentrations is not consistent and may be due to the field sampling method or the laboratory analysis procedures. 


\section{CHAPTER 8}

\section{QUALITY ASSURANCE PROGRAMS}

\subsection{Quality Assurance (QA) for Environmental Programs}

\section{Policies and Responsibilities}

The ES\&H Directorate (3200) has the overall responsibility for ensuring the quality of all activities related to environmental protection and compliance. A QA Program Plan was issued in June 1989 to address the policy, activities, and responsibilities of this Directorate for the promotion of quality throughout its operations.

The Environmental Programs Department (3220, formerly 3202), under the direction of the ES\&H Directorate (3200), has developed its own QA Plan. This QA Plan defines an approach to ensure that $3220^{\prime} \mathrm{s}$ work (items and services) meet or exceed SNL, Albuquerque; DOE (DOE/AL 5700.6B); and applicable regulatory (EPA, Occupational Safety and Health Administration (OSHA), state, and local) requirements. The 3220 QA Plan supplements the SNL, Quality Plan (corporate) and the SNL ES\&H Directorate Quality Plan.

It is the responsibility of each employee in 3220 to ensure that all activities performed by or for 3220 are in accordance wich the policies and guidelines set in the 3200 ES\&H Quality Plan and the 3220 QA Plan.

\section{New Programs}

The 3220 QA Plan was issued in November 1989. It is written in accordance with the guidelines set in DOE/AL 5700.6B (General Operations Quality Assurance), the SNL (corporate) Quality Plan, and the 3200 ES\&H Directorate Quality Plan.

This comprehensive QA Plan describes QA guidelines and standards for all activities and functions conducted by or for 3220. It stresses prevention of problems by ensuring that requirements are defined in documents such as plans and procedures, and that the requirements are understood (through familiarization and training) to enable 3220 staff to "get it right the first time" where the "it" is the requirements. There is an ongoing effort to include applicable quality elements from the 3220 QA Plan into implementation plans and procedures within 3220 for all hazardous, radioactive, MW operations, environmental protection, remediation, and compliance activities.

The 3220 QA P1an includes 18 quality elements. These elements are listed in Appendix E, Table E.5. 


\subsection{Quality Assurance (QA) of Environmental Sampling and Analysis}

There were various types of informal (unwritten) and formal (written) QA Plans that covered the activities of Environmental Protection Program in the past. All QA related activities and results have been summarized and published every year in the Annual Site Environment Report, although there was no formal QA Plan written for Department 3220 (formerly Division 3202) until 1989 .

The existing environmental montoring activities that are under the auspices of the 3220 QA Plan are listed as follows:

\section{A. Environmental Sampling}

Sample collection and chain-of-custody procedures were developed. To help ensure compliance with EPA SW-846, environmental samples are collected by trained personnel only in accordan with section 8.0 of the 3220 QA Plan.

B. Radioactive Analys is

Samples are analyzed using standard procedures. Instruments are calibrated using approved procedures that ensure traceability to the SNL Standards Laboratory and/or directly to the National Institute of Standards (NIST) (formerly National Bureau of Standards (NBS)) or other nationally recognized standards.

Laboratory QA is achieved through successful participation in EPA (Environmental Monitoring Systems Laboiatory) and DOE (Environmental Measurements Laboratory) intercomparison programs. Table 8-1 provides results for 1989 gross $\alpha$, gross $\beta, 137 \mathrm{Cs}, 3_{\mathrm{H}}$, and urinium determinations in water, soil and vegetation. Ratios comparing SNL, Albuquerque, values to reference values provided by EPA and DOE laboratories for QA programs are included. All results are acceptable in comparison to program values except that ${ }^{137} \mathrm{C}$, , $40 \mathrm{~K}$, and total $u$ values in soil and vegetation are bias high. The problems are being investigated. Corrective actions will be performed once the problems are identified. Table 8-2 lists the results of samples collected at the same location to determine sample variability. This approach is part of the routine sampling program.

Three sets of replicate samples of soil and vegetation were collected in order to get an estimate of the variability associated with each location. Table 8-2 1 ists $x$ and standard error of the mean $\left(s_{X}\right)$ for the replicate samples. This estimate of variability includes both the sampling error and the analytical and counting errors. The reported $137 \mathrm{Cs}$ levels reflect background fallout concentrations. Potassium-40 $(40 \mathrm{~K})$ is a naturally occurring background radionuclide, as are uranium and tritium. 


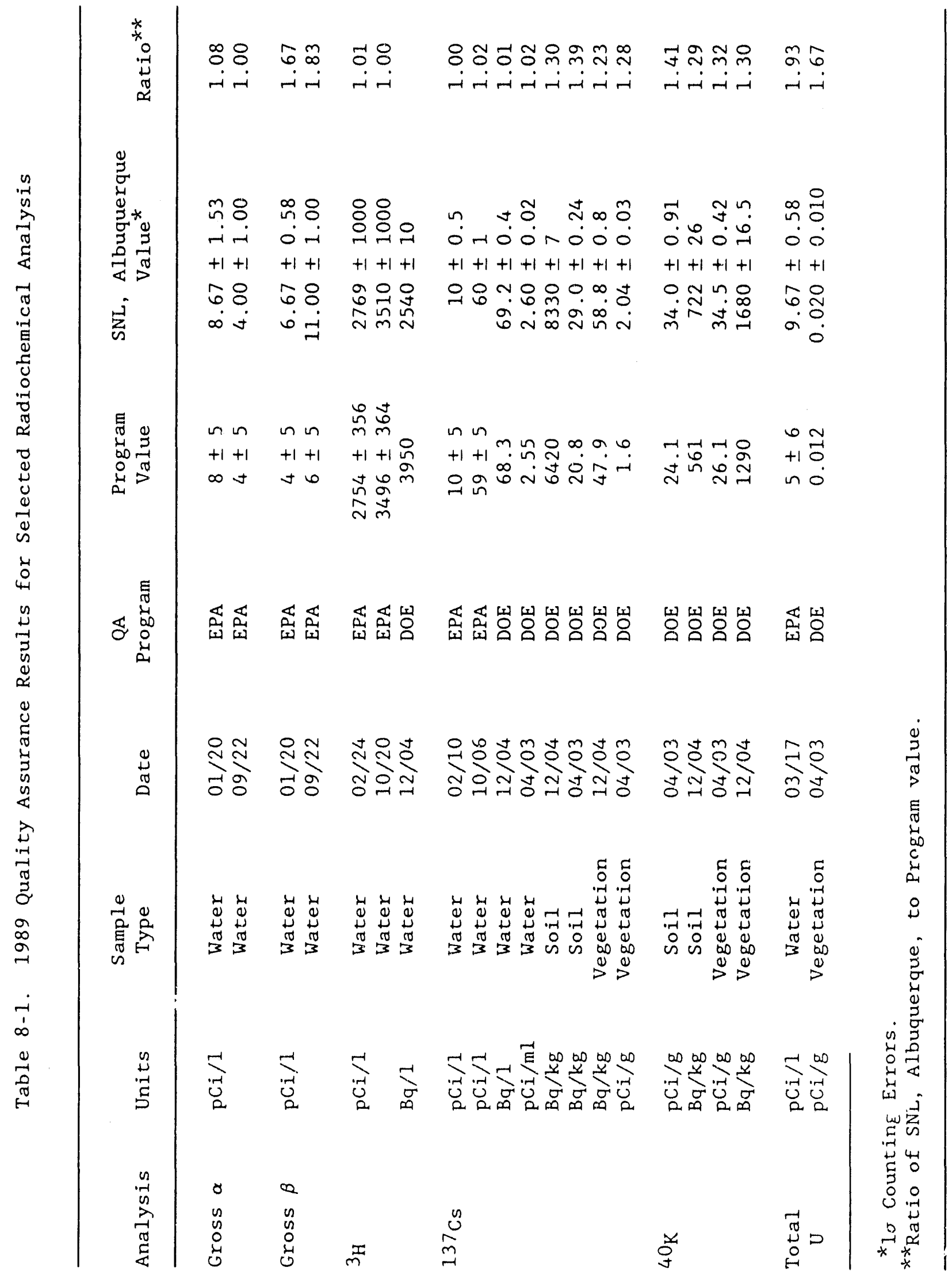




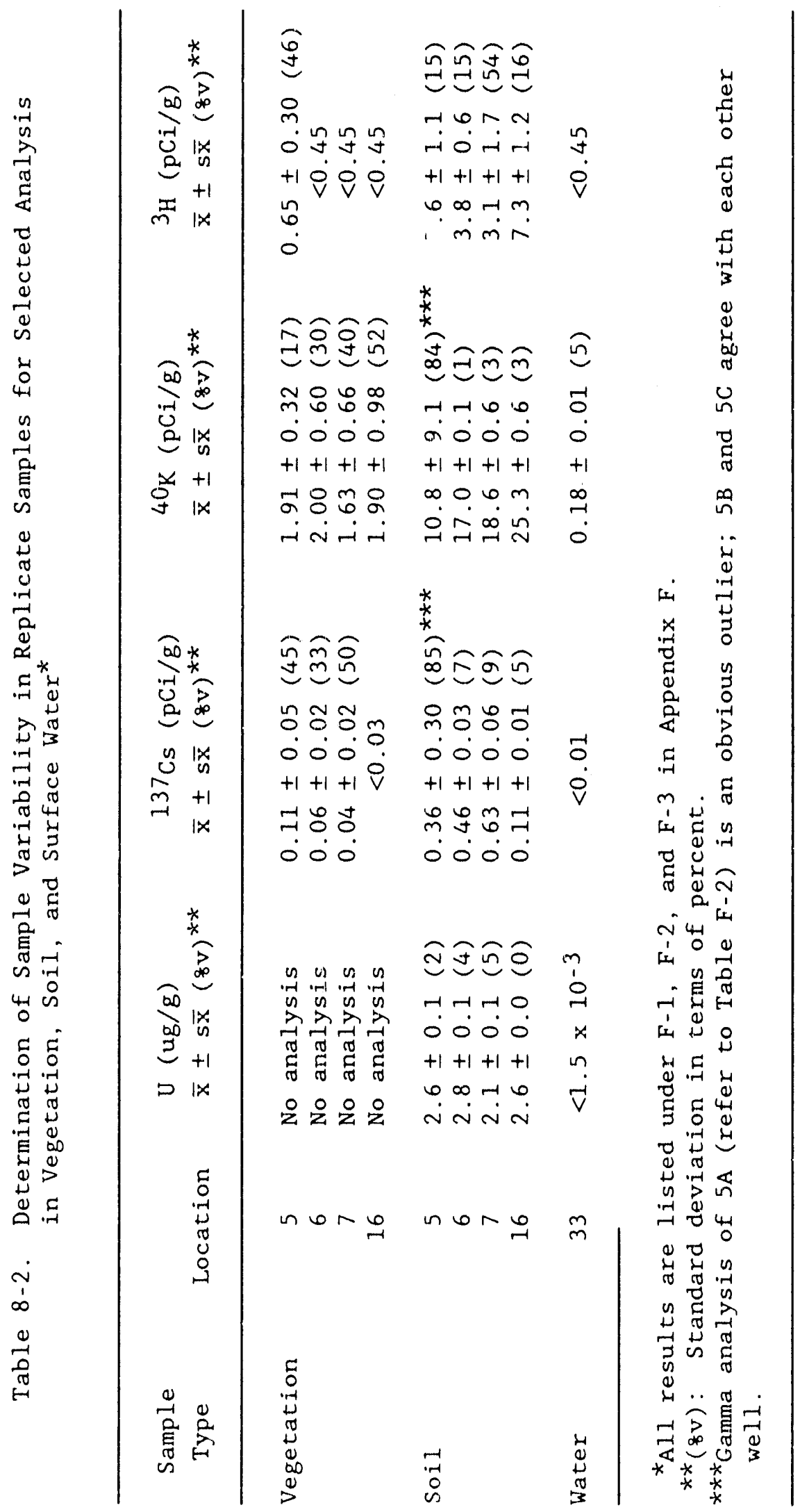




\section{Nonradioactive Analysis}

Ninety percent of the nonradioactive analyses are performed by outside contractors. The contracts stipulate that the laboratories implement and report QC data with the analytical results.

- Groundwater Samples

A Groundwater Sampling Plan is currently documented and in place. QC includes the analytical laboratory's routine QC procedure, which is audited by SNL, Albuquerque. Also, blanks and replicate samples are submitted with all field samples.

- Wastewater Samples

A Wastewater Sampling Plan for SNL, Albuquerque, is in draft form and will be finalized by May 1990. The Plan describes or references procedures for sample handling (e.g., preservation) equipment maintenance, sample logs, sample-collection frequencies, chain-of-custody, analytical methods, data storage and reporting, and laboratory QC samples. The Plan will be written and issued in accordance with applicable Sections of the 3220 QA Plan.

\section{- $\quad \underline{P C B}$ and Asbestos Analysis}

The quality of $P C B$ and asbestos analysis are evaluated through check samples, blanks, and replicate sampling programs. Analyses are performed by various laboratories and the results evaluated for their conformance to quality requirements.

\subsection{Quality Assurance (QA) of Data Management}

All data received from test laboratories were reviewed by a SNL staff or consultant independent of the test laboratories. The staff or consultant then submitted the reports to the responsible 3220 project leader. The project leaders maintained all of the reports. According to Section 17 of the 3220 QA Plan, these records are being formally accepted by 3220 staff and submitted to specific files in the 3220 Records Center. The Records Center maintains all data files related to this report.

\subsection{Quality Assurance (QA) of Outside Analytical Laboratories}

Appraisals of contractor laboratories (pre-award audits) are conducted in accordance with Section 4 of the 3220 QA Plan before an analysis laboratory is selected. Annual appraisals (e.g., inspections or audits) are subsequently conducted at the contractor laboratories in accordance with Sections 10 and/or 18 of the 3220 QA Plan. Trip blanks, check samples, and replicates are submitted with the wastewater samples for analyses. 
Current contractors were selected, in part, because of their strong QA/QC programs.

\section{Contractor QA Overview}

The Environmental Programs Department (3220) has several contractors who provide consulting, waste management and disposal, water sampling and analysis, and other analytical services. These contractors are monitored by contract monitors (with support from the 3220 QA Coordinator) through one of the following mechanisms:

A. Monitored by task (for consulting services). The project evaluation sheet was developed to evaluate individual projects. The contractors provide monthly reports on the status of progress and budget.

B. Performance checks and annual onsite appraisals (for analytical laboratories). Quarterly blind samples, replicates, and blanks are submitted to the laboratories for performance checks. Corrective actions are documented and implemented.

C. Cost-plus-award-fee contract for hazardous waste management and the environmental restoration program. The contract has a 30 percentfixed and 70 percent-variable-award fee based on quarterly performance evaluations.

In October 1988, SNL, Albuquerque, entered into 4-yr contracts with two commercial laboratories to provide analytical services to SNL, Albuquerque, in conjunction with environmental and hazardous waste programs. The laboratories that provided the majority of analytical support to SNL environmentally-related sampling activities during 1989 were Encotec (Environmental Control. Technology Corporation) located in Ann Arbor, Michigan, and Enseco, located in Arvada, Colorado. Other commercial laboratories providing analytical support during 1989 were International Technology Analytical Services Laboratories, Assagai, and TMA-Eberline. Quantities and types of analyses performed during 1989 are presented in Table E-1.

The primary contractor laboratories operate under strict QA/QC programs and routinely participate in the EPA's blind audit check sample programs. In addition, contracts with these laboratories stipulate that the laboratories concurrently analyze laboratory QC samples with all analytical batches containing SNL, Albuquerque, samples to monitor laboratory control and include results of these analyses in the analytical report.

To enhance confidence in quality of data generated by the contractor laboratories, SNL, Albuquerque, has implemented its own laboratory performance program to monitor the laboratories overall analytical precision and accuracy for analyses routinely performed on SNL, Albuquerque, samples. During 1989, a total of 171 environmental duplicate samples and 219 check samples were submitted to the contractor laboratories 
at defined frequencies as double-blind samples along with routine environmental samples. Replicate environmental samples were submitted to each laboratory on monthly or quarterly basis to monitor and document analytical precision. Check samples were submitted to the laboratories on a quarterly or semiannual basis based on the frequency and type of samples submitted to assess and document laboratory precision and accuracy.

Environmental samples collected in conjunction with the Sandia Wastewater Monitoring program were submitted to the Encotec laboratory for analysis on a monthly basis during 1989. Duplicate samples were submitted to Encotec on a monthly basis and check samples on a quarterly basis. Samples were collected in conjunction with the SNL, Albuquerque, Groundwater Monjtoring program on a quarterly basis and submitted to Enseco for analysis. Environmental duplicate samples were submitted to Enseco on a quarterly basis and check samples submitted on a semiannual basis. Precision was assessed by calculating relative percent difference (RPD) for replicate analyses performed. Results of duplicate analyses performed during 1989, and statistical data are summarized in Tables $8-3$ and $8-4$. As indjcated in the tables, the majority of analytical data are below method detection limits and, thus, RPD could not be calculated. Ninety-three perent and 86 percent of reported duplicate environmental sample analyses data with calculable results were within the control limit of 20 pexcent for the Encotec and Enseco laboratories, respectively. When calculated RPDs for analyzed constituents analytes were outside the acceptance range, the analytes in question were carefully reviewed by SNL, Albuquerque, staff to determine if reanalysis was necessary.

Check samples submitted to the laboratories were prepared by an outside laboratory or the EPA and submitted to the contractor laboxatories at the frequencies indicated above. Check samples used were prepared in batch quantities and subjected to round-robin analyses for verification of check sample analyte concentrations. The samples were prepated by spiking concentrated solutions containing analytes of interest into reagent grade water free of analytical interferents to create check samples at concentration ranges at one to five times the method detection limit. The check samples were prepared in duplicate so that analytical precision as well as accuracy could be assessed. Check samples submitted to the laboratories consisted of solutiors containing trace metals, cyanides, phenolic compounds, and other selected anions and cations. In addition to aqueous samples, oil samples prepared by the EPA containing known concentrations of polychlorinated biphenyls were submitted to both laboratories for analysis.

Results of each set of cherk sample analyses are summarized in Appendix E, Tables E-3 and E-4 for the Enseco and Encotec laboratories, respectively. The tables include average percent recoveries for each suite of samples analyzed and the relative range of actual recoveries and relative percent differences for each analyte tested. The resulting data were used to assess each laboratory's performance using relative percent difference and 
Table 8-3. Summary of Relative Percent Difference Measurements for Environmental Duplicate Sample Analyses Performed During 1989 at ENSECO

\begin{tabular}{|c|c|c|c|c|}
\hline PARAMETER & DEC 88 & MAR 89 & JUN 89 & SEP 89 \\
\hline Arsenic & NC & $\mathrm{NC}$ & $\mathrm{NC}$ & $\mathrm{NC}$ \\
\hline Barium & 0 & 0 & 0 & 0 \\
\hline Cadmium & NC & $\mathrm{NC}$ & $\mathrm{NC}$ & NC \\
\hline Chloride & 2 & 2 & 6 & 4 \\
\hline Chromium & NC & $\mathrm{NC}$ & 22 & 40 \\
\hline Fluoride & 0 & 6 & 7 & 0 \\
\hline Iron & NC & 0 & 0 & $\mathrm{NC}$ \\
\hline Lead & $\mathrm{NC}$ & NC & $\mathrm{NC}$ & NC \\
\hline Manganese & 9.5 & 0 & 50 & $\mathrm{NC}$ \\
\hline Mercury & NC & $\mathrm{NC}$ & $\mathrm{NC}$ & $\mathrm{NC}$ \\
\hline Nitrate (as N) & 20 & 0 & 0 & 0 \\
\hline $\mathrm{pH}$ & 0 & 4 & & \\
\hline Phenols & NC & NC & NC & $\mathrm{NC}$ \\
\hline Selenium & NC & NC & NC & $\mathrm{NC}$ \\
\hline Silver & NC & NC & NC & $\mathrm{NC}$ \\
\hline Sodium & 1 & 0 & 3 & 1 \\
\hline $\begin{array}{l}\text { Specific } \\
\text { Conductance }\end{array}$ & 6 & 2 & 4 & 0.4 \\
\hline Sulfate & 1 & 2 & 7 & 5 \\
\hline $\begin{array}{l}\text { Total Organic } \\
\text { Carbon }\end{array}$ & 114 & 29 & $\mathrm{NC}$ & $\mathrm{NC}$ \\
\hline $\begin{array}{l}\text { Total Organic } \\
\text { Halogen as } \mathrm{Cl}\end{array}$ & 85 & $\mathrm{NC}$ & 10 & 2 \\
\hline
\end{tabular}


Table 8-4. Summary of Relative Percent Difference Measurements for Environmental Duplicate Sample Analyses Performed During 1989 at ENCOTEC

\begin{tabular}{llllllllll}
\hline MONTH & MAR & APR & MAY JUN JUL AUG & SEP & OCT & NOV & DEC & DEC \\
\hline
\end{tabular}

Parameter

$\mathrm{Cd}$ $3.8 \quad \mathrm{NC} \quad 12 \quad \mathrm{NC}$

NC

$\mathrm{NC}$

$\operatorname{Cr}(\operatorname{tota})$

$1.9 \quad N$

NC NC

1

$\mathrm{NC} \quad \mathrm{NC}$

NC

NC NC NC

$\mathrm{Cu}$

$5.7 \quad 22$

0

0

11

$\mathrm{NC} \quad \mathrm{NC}$

NA NC NC NC

$\mathrm{CN}$ (total) NC $12 \quad \mathrm{NC} \quad 10$

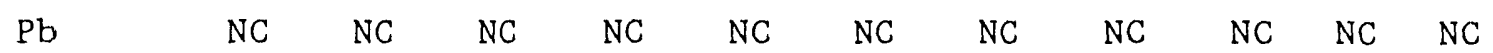

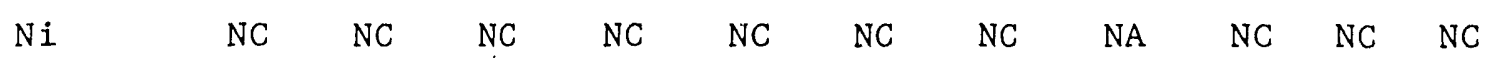

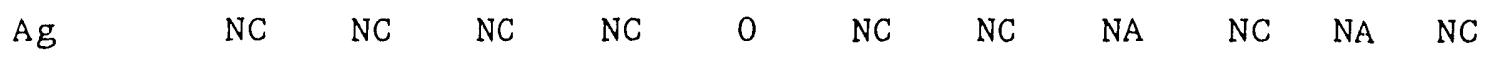

$\begin{array}{llllllllllll}\mathrm{Zn} & 1.6 & 0 & \mathrm{NC} & 3.5 & 6 & \mathrm{NC} & \mathrm{NC} & 183 & \mathrm{NC} & \mathrm{NC} & \mathrm{NC}\end{array}$

$\begin{array}{llllllllllll}\mathrm{F} & 1.8 & 26.4 & 0 & \mathrm{NA} & \mathrm{NA} & \mathrm{NA} & 3 & 1.4 & 2.7 & 0 & 11.8\end{array}$

$\mathrm{NC}=$ Not Calculable

NA $=$ Not Applicable

* Duplicate samples for December 1989.

percent recovery for respective indicators of precision and accuracy. As indicated in the tables, the majority of reported values were within the acceptance limits identified.

Review of QC data suggests difficulties may exist with silver, cyanide, and mercury analyses performed at Encotec and witk phenolics, sulfate, conductivity, and TOC analyses at Enseco. A concerted effort to identify deficiencies in the laboratory systems and resolve these issues will be undertaken when sufficient data exist to pinpoint these areas. During 1990, Sill, Albuquerque, is planning to increase the volume of QC samples sent to the contractor laboratories and continue to monitor overall laboratory performance. 


\section{REFERENCES}

Albuquerque District Corps. of Engineers, 1979. Albuquerque Greater Urban Area Water Supply Study, Albuquerque, NM, September 1979.

Anderholm, S. K., 1988. "Ground-water Geochemistry of the AlbuquerqueBelen basin, Central New Mexico," Report 86-4094, United States Geological Survey (USGS) Water-Rusources Investigations.

Bjorklund, L. J. and B. W. Maxwe11, 1961. "Availability of Ground Water in the Albuquerque Area, Bernalillo and Sandoval Counties, New Mexico," Report 21, New Mexico State Engineer.

Brewer, L. W., 1973. "Environmental Monitoring Report for Sandia National Laboratories From 1964 Through 1972," SLA73-0339, Sandia National Laboratories, Albuquerque, NM, April 1973.

Brewer, L. W., 1974. "Environmental Monitoring Report for Sandia National Laboratories for 1973," SLA-74-0167, Sandia National Laboratories, Albuquerque, NM, April 1974.

Bryan, K., 1938. "Geology and Groundwater Conditions of the Rio Grande Depression in Colorado and New Mexico," U.S. Natural Resources Planning Board, the Rio Grande Joint Investigations in the Upper Rio Grande Basin, Vol. 1, Part 2, U.S. Government Printing Office, Washington, D.C.

Burnett, W. D., D. J. Coleman, R. G. Elsbrock, and R. J. Everett, 1961. "Radioactive Environmental Survey at Sandia Corporation," SC-4628(M), Sandia National Laboratories, Albuquerque, NM, May 1961.

Ecology and Environment, Inc., 1989. "Statement of Work: Installation of Groundwater Monitoring Wells for RCRA Compliance Closure of the Mixed Waste Landfill," prepared for Sandia National Laboratories, Albuquerque, NM, May 1989.

Energy Research and Development Administration (ERDA), 1977. "Environmental Impact Assessinent, Sandia National Laboratories, Albuquerque, New Mexico," EIA/MA 77-1, ERDA, May 1977.

Environmental Surveillance Group, Los Alamos National Laboratory, ij 2. "Environmental Surveillance at Los Alamos During 1981," LA-9349-Env, Los Alamos National Laboratory, Los Alamos, NM, April 1982.

Fish, J., 1990. "Waste Management Site Plan FY 1989," Plan 90-07, Sandia National Laboratories, Albuquerque, NM, March 1990.

Holley, W. L., 1975. "Environmental Monitoring Report, Sandia Laboratories 1974," SAND75-0257, Sandia National Laboratories, Albuquerque, NM, April 1975. 
Holley, W. L., and T. N. Simmons, 1976. "Environmental Monitoring Report, Sandia Laboratories 1975," SAND76-0209, Sandia National Laboratories, Albuquerque, NM, April 1976.

International Technologies Corporation (IT Corporation), 1985. "RCRA Interim Status Groundwater Monitoring Plan," prepared for Sandia National Laboratories, Albuquerque, NM, May 1985.

International Technologies Corporation (IT Corporation), 1989. "Quarterly Ground-Water Sampling Report, March 22 through 29, 1989," prepared for Sandia National Laboratories, Albuquerque, NM, May 1989.

International Technologies Corporation (IT Corporation), 1989. "Quarterly Ground-Water Sampling Report, June 12 through 16, 1989," prepared for Sandia National Laboratories, Alhuquerque, NM, August 1989.

International Technologies Corporation (IT Corporation), 1989. "Quarterly Ground-Water Sampling Report, September 6 through 29, 1989," prepared for Sandia National Laboratories, Albuquerque, NM, November 1989.

Kelley, V. C., 1977. "Geology of Albuquerque Basin, New Mexico," Memoir 33. New Mexico Bureau of Mines and Mineral Resources.

Kues, G. E., 1987. "Ground-Water-Level Data for the Albuquerque-Belen Basin, New Mexico, Through Water Level Year 1985," Open File Report 87-116, U.S. Geological Survey.

Masuda, A., 1964. Distribution of Thorium, Uranium, and Potassium and Radioactive Heat Production as a Function of Depth of Earth, Rep. INSJ-65, Institute of Nuclear Studies, Japan.

Millard, G. C., 1986. "Environmental Monitoring Manual," Sandia National Laboratories, Albuquerque, December 1986.

Millard, G. C., 1981. "Environmental Monitoring Report, Sandia National Laboratories 1980," SAND81-0566, Sandia National Laboratories, Albuquerque, NM, April 1981.

Millard, G. C., C. E. Gray, T. N. Simmons, B. L. O'Neal, 1982. "1981 Environmental Monitoring Repcst, Sandia National Laboratories, Albuquerque, New Mexico," SAND82-0833, Sandia National Laboratories, Albuquerque, NM, April 1981

Millard, G. C., C. E. Gray, B. L. O'Neal, 1984. "1983 E'vironmental Monitoring Report, Sandia National Laboratories, Albuquerque, New Mexico," SAND84-0429, Sandia National Laboratories, Albuquerque, NM, April 1984.

Millard, G. C., C. E. Gray, T. N. Simmons, and B. L. O'Neal, 1983. "1982 Environmental Monitoring Report, Sandia National Laboratories, Albuquerque, New Mexico," SAND83-0789, Sandia National Laboratories, Albuquerque, NM, April 1983. 
Millard, G. C., C. E. Gray, and D. J. Thompson, 1985. "1984 Environmental Monitoring Report, Sandia National Laboratories, Albuquerque, New Mexico," SAND85-0550, Sandia National Laboratories, Albuquerque, NM, Apri1 1985.

Millard, G. C., C. E. Gray, and D. J. Thompson, 1986. "1985 Environmental Monitoring Report, Sandia National Laboratories, Albuquerque, New Mexico," SANT 86-0752, Sandia National Laboratories, Albuquerque, NM, April 1986.

Millard, G. C., P. Pei, S. Felicetti, C. Gray, D. Thompson, and J. Phelan, 1987. "1986 Environmental Monitoring Report, Sandia National Laboratories, Albuquerque, New Mexico," SAND87-0606, Sandia National Laboratories, Albuquerque, NM, April 1987.

Millard, G. C. P. Pei, S. Felicetti, C. Gray, D. Thompson, and J. Phelan, 1988. "1987 Environmental Monitoring Report, Sandia National Laboratories, Albuquerque, New Mexico," SAND88-0697, Sandia National Laboratories, Albuquerque, NM, April 1988.

Millard, G. C., G. Yeager, J. Phelan, T. Wolff, P. Pei, D. Dionne, C. Gray, D. Thompson, and R. Hamilton, 1989. "1988 Environmental Monitoring Report, Sandia National Laboratories, Albuquerque, New Mexico," SAND89-1368, Sandia National Laboratories, Albuquerque, NM, May 1989.

National Oceanographic and Atmospheric Administration (NOAA), 1968. in "Summary of Hourly Observations, Albuquerque, New Mexico, Municipal Airport 1951-1960," "Climatography of the United States No. 82-89," NOAA, Washington, D.C.

National Oceanographic and Atmospheric Administration (NOAA), 1983. "Local Climatological. Data, Annual. Summary with Comparative Data," Albuquerque, NM.

01son, O., M. H. Hall, and, H, Plagge, 1970. "Wind Data for the Albuquerque Area," SC-M-70-144, Sandia National Laboratories, Albuquerque, NM, May 1970.

Parsons, A. M., 1990. "Calendar Year 1989 Groundwater Monitoring Program Annual Report," Sandia National Laboratories," Albuquerque, NM, February 1990.

Reeder, H. O., L. J. Bjorklund, and G. A. Dinwiddie, 1967. "Quantitative Analysis of the Water Resources in the Albuquerque Area, New Mexico," Technical Report 33, New Mexico State Engineer Report.

Reineck, H. E. and I. B. Singh, 1975. Depositional Sedimentary Environments, New York: Springer-Verlag.

Sandia National Laboratories (SNL), Albuquerque, 1988. "Chemical. Waste Landfill Sampling and Analysis Plan, " Draft Report, Sandia National. Laboratories, NM, Albuquerque, April 1988.

Science Apjilications International Corporation (SAIC), 1985." "Instajlation Restoration Program Phase II - Confirmation/Quantification Stage I, "Report $2-827-06-351-33$, SAIC. 
Simmons, T. N., 1977. "Environmental Monitoring Report, Sandia Laboratories 1976," SAND77-0616, Sandia National Laboratories, Albuquerque, NM, April 1977.

Simmons, T. N., 1978. "Environmental Monitoring Report, Sandia Laboratories 1977," SAND78-0620, Sandia National Laboratories, Albuquerque, NM, April 1978.

Simmons, T. N., 1979. "Environmental Monitoring Report, Sandia Laboratories 1978," SAND79-1033, Sandia National Laboratories, Albuquerque, NM, April 1979.

Simmons, T. N., 1980. "Environmental Monitoring Report, Sandia Laboratories 1979," SAND80-0342, Sandia National Laboratories, Albuquerque, NM, April 1980.

U.S. Bureau of the Census, 1981. "1980 Census of Population and Housing," PHC80-V-33, U.S. Government Printing Office, March 1981.

U.S. Department of Energy (DOE), 1981. "A Guide for Environmental Radiological Surveillance at U.S. Department of Energy Installations," DOE/EP-0023, U.S. Department of Energy, July 1981.

U.S. Department of Energy (DOE), 1988. "RCRA Groundwater Monitoring Plan, Sandia National Laboratories, Albuquerque," U.S. Department of Energy, December 1988.

U.S. Environmental Protection Agency (EPA), 1986. RCRA Ground Water Monitoring Technical Enforcement Guidance Document, EPA, Washington, D.C. 
APPENDIX A

METEOROLOGICAL DATA

A. - $1 / 2$ 
Tab]e A-1. Long-Term Historical Data (1951 to 1980)

for the Albuquerque Area*

\begin{tabular}{|c|c|c|c|c|c|}
\hline Month & $\begin{array}{c}\text { Temperat } \\
\text { Daily } \\
\text { Min }\end{array}$ & $\begin{array}{l}\text { ures }\left({ }^{\circ} \mathrm{C}\right) \\
\text { Range } \\
\operatorname{Max}\end{array}$ & $\begin{array}{l}\text { Precipitation } \\
(\mathrm{cm}) \text { Water } \\
\text { Equivalent }\end{array}$ & $\begin{array}{c}\text { Speed } \\
\mathrm{m} / \mathrm{s}\end{array}$ & $\begin{array}{l}\text { Wind } \\
\text { Direction }\end{array}$ \\
\hline Jan & -5.4 & 8.4 & 1.04 & 3.6 & $\mathrm{~N}$ \\
\hline $\mathrm{Feb}$ & -3.4 & 11.6 & 1.02 & 4.0 & $\mathrm{~N}$ \\
\hline $\operatorname{Max}$ & -0.2 & 15.9 & 1.32 & 4.6 & $S E$ \\
\hline Apr & 4.2 & 21.4 & 1.02 & 5.0 & $S$ \\
\hline May & 9.2 & 26.6 & 1.17 & 4.7 & $S$ \\
\hline Jun & 14.7 & 32.6 & 1.30 & 4.5 & $S$ \\
\hline Jul & 18.2 & 33.8 & 3.30 & 4.1 & $\mathrm{SE}$ \\
\hline Aug & 17.1 & 31.9 & 3.84 & 3.7 & $S E$ \\
\hline Sep & 12.7 & 28.3 & 2.16 & 3.9 & $\mathrm{SE}$ \\
\hline Oct & 6.2 & 22.1 & 2.18 & 3.7 & $\mathrm{SE}$ \\
\hline Nov & -0.7 & 14.0 & 0.97 & $3.5:$ & $\mathrm{N}$ \\
\hline $\mathrm{Dec}$ & -4.9 & 8.9 & 1.32 & 3.5 & $N$ \\
\hline \multicolumn{6}{|c|}{$\begin{array}{l}\text { *NOAA, Local Climatological Data, Annual Summary with Comparative Data, } \\
\text { Albuquerque, New Mexico, } 1983 \text {. Values are in parenthesis. Temperature } \\
\text { and precipitation values are normals recorded for the } 1951 \text { to } 1980 \\
\text { period. Wind direction is prevailing direction through } 1963 \text {. Average } \\
\text { wind speeds are reported. The data were collected at the International } \\
\text { Albuquerque Airport-Kirtland AFB, elevation } 1.62 \mathrm{~km} \text {. The original } \\
\text { measurements have been converced to metric units. }\end{array}$} \\
\hline
\end{tabular}


Table A-2. Normals, Means, and Extremes, Albuquerque

New Mexico for 1951 to 1980 (NOAA, 1985)

\section{NORMALS, MEANS, AND EXTREMES \\ ALBUQUERQUE. NEW MEXICO}

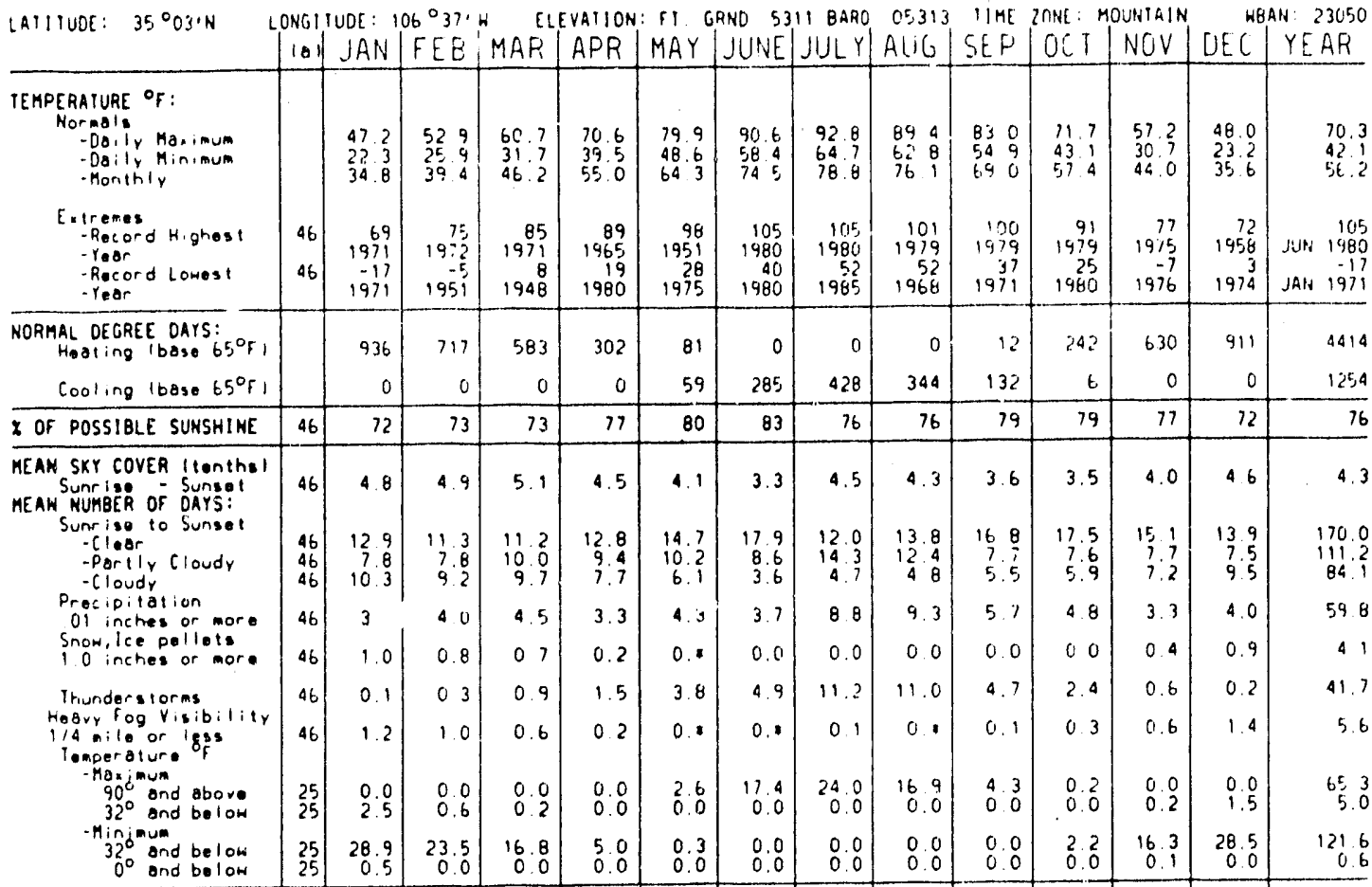

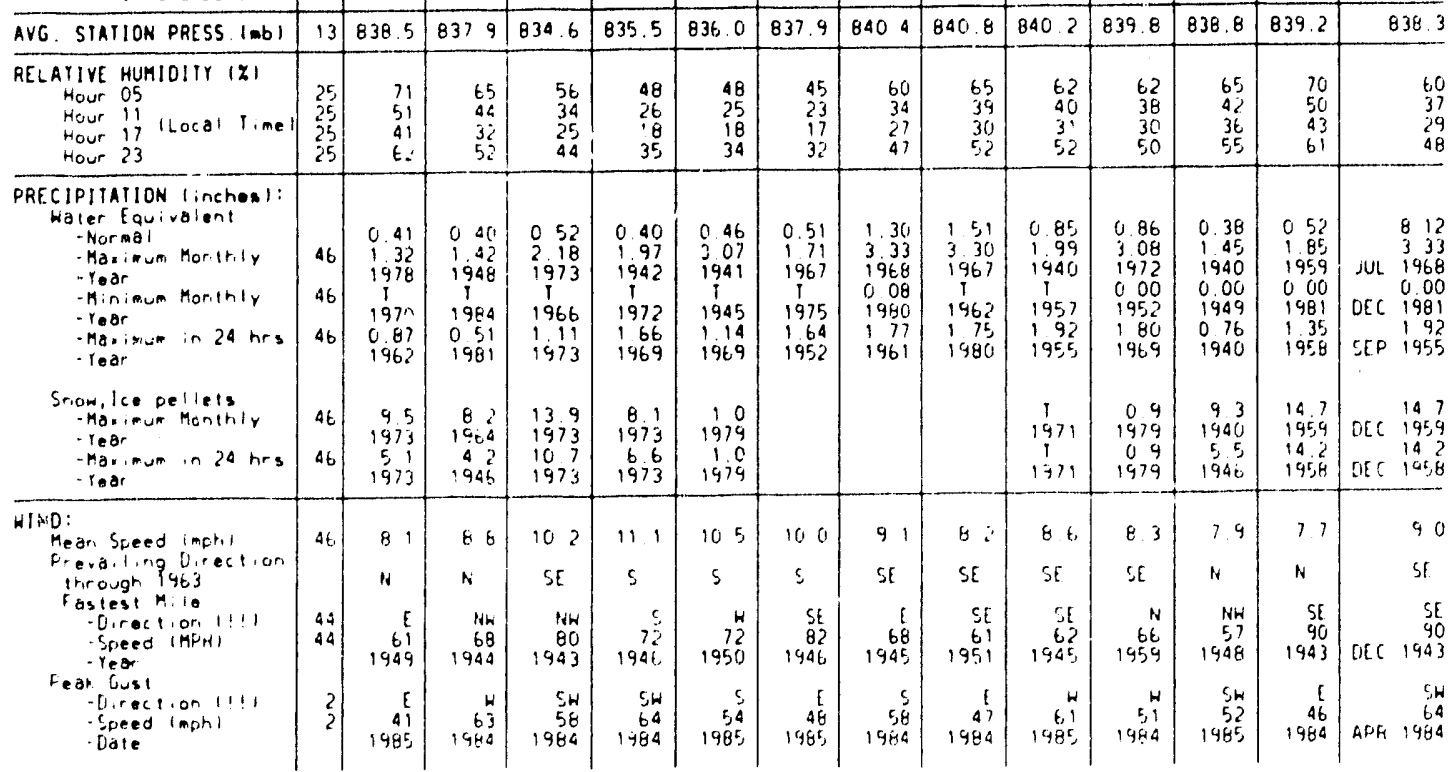




\section{REFERENCES}

National Oceanographic and Atmospheric Administration (NOAA), 1985. "Local Climatological Data, Annual Summary with Comparitive Data," Albuquerque, NM. 


\section{APPENDIX B \\ SANDIA NATIONAL LABORATORIES, ALBUQUERQUE, ENVIRONMENTAL RESTORATION PROGRAM SITES}


Table B-1. Sandia National Laboratories, Albuquerque, Environmental Restoration Program Sites

\begin{tabular}{|c|c|c|}
\hline $\begin{array}{c}\text { ER Program } \\
\text { Task }\end{array}$ & $\begin{array}{c}\text { ER Program } \\
\text { Site No. }\end{array}$ & Site Name \\
\hline I. HIGH PRIO & TY TASKS & \\
\hline$A L-S A-R C-1$ & 74. & Chemical Waste Landfill \\
\hline$A L-S A-R C-2$ & 76. & Mixed Waste Landfill \\
\hline $\begin{array}{l}\text { AL-SA, }-1 \\
(\mathrm{TA} 3 \text { and } 5)\end{array}$ & $\begin{array}{l}4 . \\
5 . \\
18 . \\
26 . \\
31 . \\
34 . \\
35 . \\
36 . \\
37 . \\
51 . \\
52 . \\
78 . \\
83 \\
84 . \\
100 \\
102 . \\
105 \\
107 \\
111\end{array}$ & $\begin{array}{l}\text { Radioactive Surface Impoundment } \\
\text { Radioactive Seepage Basin } \\
\text { Storage and Salvage Yards } \\
\text { Burial Site (west fence of TA 3) } \\
\text { Elect. Transformer Oil Spill (Phase 5) } \\
\text { Centrifuge Oil Spill (Phase 5) } \\
\text { Vibration Facility Oil Spill (Phase 5) } \\
\text { Oil Spil? - HERMES } \\
\text { PROTO Oil Spill } \\
\text { Bldg 6924 (pad, tank, pit) } \\
\text { Sandia Engineering Reactor } \\
\text { Gas Cylinder Disposal Pit } \\
\text { Sled Tracks } \\
\text { Gun Facilities (Area III) } \\
\text { Bldg. 6620 HE Sump/Drain } \\
\text { Rad Disposal Site (E of TA 3) } \\
\text { Mercury (Bldg. 6536) } \\
\text { Explosive Test Area (SE TA 3) } \\
\text { Bldg. 6715 Sump/Drains }\end{array}$ \\
\hline $\begin{array}{l}\text { AL-SA-2 } \\
\left(\begin{array}{ll}T A & 2\end{array}\right)\end{array}$ & $\begin{array}{l}1 . \\
2 . \\
3 \\
43 \\
44 \\
50 \\
113 \\
114 \\
159\end{array}$ & $\begin{array}{l}\text { Radioactive Burial Site } \\
\text { Classified Waste Disposal Trenches } \\
\text { Chemical Disposal Pit } \\
\text { Radioactive Storage Yard } \\
\text { Decontamination Site } \\
\text { Old Centrifuge Site } \\
\text { Area II Firing Sites } \\
\text { Explosive Burn Pit } \\
\text { Bldg. } 935 \text { Floor Drains and Septic System }\end{array}$ \\
\hline $\begin{array}{l}\text { AL-SA-19 } \\
\text { (Septic } \\
\text { Tanks and } \\
\text { Drainfields) }\end{array}$ & $\begin{array}{l}48 \\
135 \\
136 \\
137 \\
138 \\
139\end{array}$ & $\begin{array}{l}\text { B1dg. } 904 \\
\text { Bldg. } 906 \\
\text { Bldg. } 907 \\
\text { Bldg. } 6540 / 6542 \text { Septic Tanks and Leach Field } \\
\text { Bldg. } 6630 \text { Septic Tank and Leach Field } \\
\text { Bldg. } 9964 \text { Septic lank Systems }\end{array}$ \\
\hline
\end{tabular}


Table B-1. Sandia National Laborator'es, Albuquerque, Environmental. Restoration Program Sites (Continued)

\begin{tabular}{|c|c|c|}
\hline $\begin{array}{l}\text { ER Program } \\
\text { Task }\end{array}$ & $\begin{array}{c}\text { ER Program } \\
\text { Site No. }\end{array}$ & Site Name \\
\hline & $\begin{array}{l}140 . \\
141 \\
142 . \\
143 \\
144 \\
145 \\
49 \\
116 \\
101 \\
146 \\
147 \\
148 \\
149 \\
150 \\
151 \\
152 \\
153 \\
154 \\
161\end{array}$ & $\begin{array}{l}\text { Bldg. } 9965 \text { Septic Tank and Seepag Pit } \\
\text { Bldg. } 9967 \text { Septic Tank and Seepage Pit } \\
\text { Bldg. } 9970 \text { Septic Tank and Seepage Pit } \\
\text { Bldg. } 9972 \text { Septic Tank and Leach Field } \\
\text { Bldg. } 9980 \text { Septic Tank Systems } \\
\text { Bldg. } 9981 / 9982 \text { Septic Tank and Leach Field } \\
\text { Bldg. } 9820 \text { Drains } \\
\text { Bldg. } 9990 \text { Septic Tank and Drain Fields } \\
\text { Explosive Contaminated Sumps, Drains } \\
\text { Drain Fields (Bldg. } 9920 \text { ) } \\
\text { Bldg. } 9925 \text { Septic Tanks and Leach Field } \\
\text { Bldg. } 9927 \text { Septic Tank and Seepage Pit } \\
\text { Bldg. } 9930 \text { Septic Tank and Seepage Pit } \\
\text { Bldg. } 9939 / 9939 \text { A Septic Tank and Seepage Pit } \\
\text { Bldg. } 9940 \text { Septic Tank and Seepage Pit } \\
\text { Bldg. } 9950 \text { Septic Tank and Leach Field } \\
\text { Bldg. } 9956 \text { Septic Tank and Leach Field } \\
\text { Bldg. } 9960 \text { Septic Tank and Seepage Pit } \\
\text { Bldg. } 6536 \text { Septic Tank and Leach Field }\end{array}$ \\
\hline $\begin{array}{l}\text { AL-SA- } 20 \\
\text { (Underground } \\
\text { Storage Tanks) }\end{array}$ & 155. & Bldg. 659725,000 Gallon UST \\
\hline
\end{tabular}

II. MEDIUM PRIORITY TASKS

$\begin{array}{lll}\begin{array}{l}\text { AL-SA-3 } \\ \text { (Coyote Cyn } \\ \text { Blast Area) }\end{array} & 8 . & \begin{array}{l}\text { Open Dump } \\ \text { Coyote Canyon Blast Area }\end{array} \\ \begin{array}{ll}\text { AL-SA-4 } \\ \text { (Thunder }\end{array} & 58 . & \text { Gas Cylinder Disposal Pit } \\ \text { Range) } & 17 . & \text { Scrap Yards/Open Dump } \\ & 39 . & \text { Oil Spill - Solar Facility } \\ & 54 . & \text { Pickax Site } \\ & 55 . & \text { Red Towers Site } \\ & 56 . & \text { Old Thunderwells } \\ & 79 . & \text { Gas Cylinder Disposal } \\ & 89 . & \text { Shock Tube Site } \\ & 90 . & \text { Beryllium Firing Site } \\ & 91 . & \text { Lead Firing Site } \\ & 110 . & \text { Thunder Range - Miscellaneous }\end{array}$


Table B-1. Sandia National Laboratories, Albuquerque, Environmental Restoration Program Sites (Continued)

ER Program
Task Program
Site No.

Site Name

$\begin{array}{ll}\text { AL-SA-5 } & 11 . \\ \text { (Central } & 19 . \\ \text { Coyote Test } & 22 . \\ \text { Field) } & 57 . \\ & 66 . \\ & 68 . \\ & 70 . \\ & 71 . \\ & 87 . \\ & 82 .\end{array}$

AL-SA- 6

(Pendulum

Area)

AL-SA- 7

(Coyote

Springs Area)
11.

19.

22.

57.

66.

68.

70.

71.

82.

10.

59.

60.

92.

21.

27.

62.

88.
Radioactive/Explosive Burial Mounds Scrap Yard (NW of old Aerial Cable) Storage/Burn Area (W of DEER) Workman Site (Phase 5) Boxcar site old Burn Site (Phase 5) Explosive Test Pit (water towers) Moonlight Shot Area Bldg. 9990

Old Aerial Cable Site (scrap yard/dump/test area)

Burial Mounds

Pendulum Site

Bunker Area

Pressure Vessel Test Site (Coyote Canyon)

Metal Scrap (Coyote Springs)

Bldg. 9820 - Animal Disposal Pit

Graystone Manor Site

Firing Sice (SW of Coyote Springs)

III. LOW PRIORITY TASKS

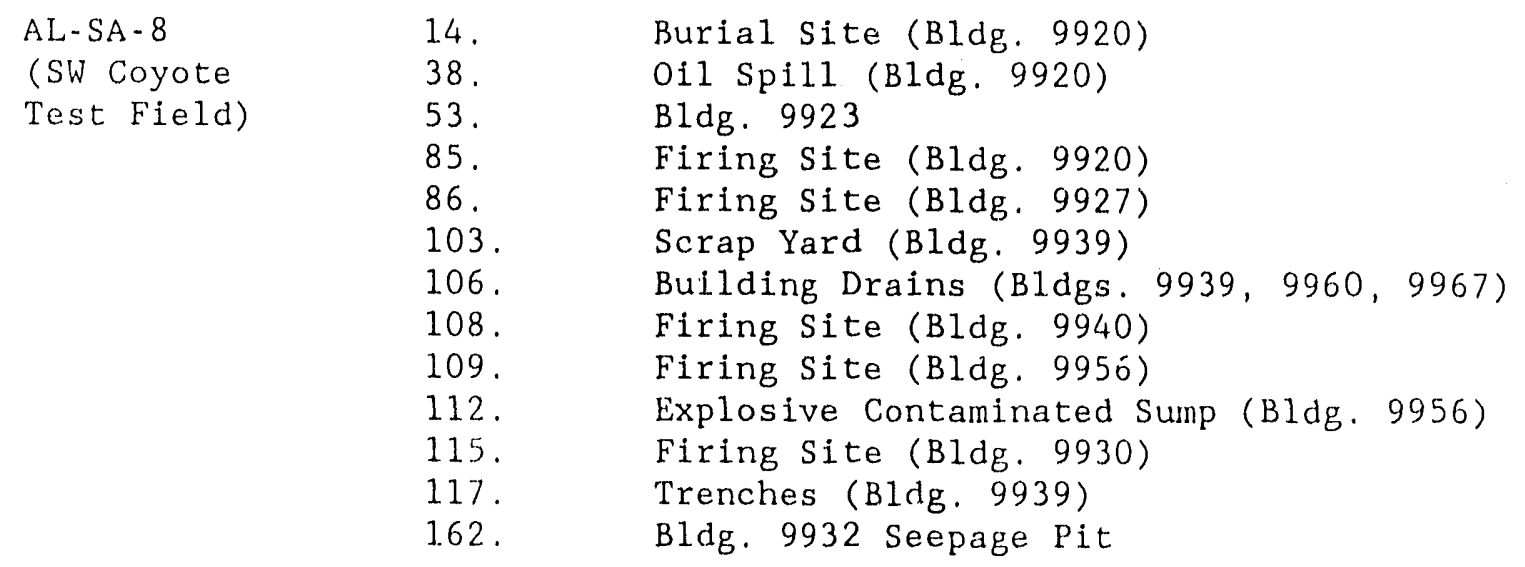

14.

Test Field)

38.

53.

85.

86.

103.

106.

108.

109.

112.

115.

117.

1.62 .

Burial Site (B1dg. 9920)

Oil Spill (Bldg. 9920)

B1dg. 9923

Firing Site (Bldg. 9920)

Firing Site (Bldg. 9927)

Scrap Yard (Bldg. 9939)

Building Drains (B1dgs. 9939, 9960, 9967)

Firing Site (Bldg. 9940)

Firing Site (Bldg. 995ó)

Explosive Contaminated Sump (B1dg. 9956)

Firing Site (Bldg. 9930)

Trenches (B1dg. 9939)

Bldg. 9932 Seepage Pit 
Table B-1. Satilia National Laboratories, Albuquerque, Environmental Restorction Program Sites (Concluded)

\begin{tabular}{|c|c|c|}
\hline $\begin{array}{c}\text { ER Program } \\
\text { Task }\end{array}$ & $\begin{array}{l}\text { ER Program } \\
\text { Site No. }\end{array}$ & Site Name \\
\hline $\begin{array}{l}\text { AL-SA-9 } \\
\left(\begin{array}{ll}\text { TA } 1\end{array}\right)\end{array}$ & $\begin{array}{l}25 \\
30 \\
32 . \\
33 \\
41 \\
42 \\
73 \\
77 \\
96 \\
104\end{array}$ & $\begin{array}{l}\text { Burial Site (S of TA 1) } \\
\text { PCB Spill (Reclamation Yard) } \\
\text { Steam Plant Oil Spill (Phase 5) } \\
\text { Motor Pool Oil Spill (Phase 5) } \\
\text { Bldg. } 838 \text { Mercury Spill } \\
\text { Acid Spill-Water Treatment Facility } \\
\text { Hazardous Waste Repackaging/Storage } \\
\text { Oil Surface Impoundment (Area IV) } \\
\text { Storm Drain System } \\
\text { PCB Spili (Compuier Facility) }\end{array}$ \\
\hline $\begin{array}{l}\text { AL-SA-10 } \\
\text { (Lurance } \\
\text { Canyon) }\end{array}$ & $\begin{array}{l}12 . \\
13 . \\
63 \\
64 . \\
65 \\
94 . \\
81 . \\
93\end{array}$ & $\begin{array}{l}\text { Burial Site/Open Dump } \\
\text { Oil Surface Impoundment (Lurance Canyon) } \\
\text { Balloon Test Area } \\
\text { Gun Site (Madera Canyon) } \\
\text { Lurance Canyon Explosive Test Site } \\
\text { Lurance Canyon Burn Site } \\
\text { New Aerial Cable Site (burial site/dump/test } \\
\text { area) } \\
\text { Madera Canyon Rocket Launcher Pads }\end{array}$ \\
\hline $\begin{array}{l}\text { AL-SA-11 } \\
\text { (Schoolhouse } \\
\text { Mesa) }\end{array}$ & $\begin{array}{l}9 \\
20 \\
61\end{array}$ & $\begin{array}{l}\text { Burial Site/Open Dump } \\
\text { Uranium Burn Site } \\
\text { Schoolhouse Mesa Test Site }\end{array}$ \\
\hline $\begin{array}{l}\text { AL-SA-12 } \\
\text { (Tijeras } \\
\text { Arroyo) }\end{array}$ & $\begin{array}{l}23 \\
24 \\
45 \\
7 \\
16 \\
40 \\
46\end{array}$ & $\begin{array}{l}\text { Disposal Treches } \\
\text { Landfill/Open Dump } \\
\text { Liquid Discharge (behind TA 4) } \\
\text { Gas Cylinder Disposal (Airoyo del Coyote) } \\
\text { Open Dumps (Arroyo Del Coyote) } \\
\text { Oil Spill ( } 6000 \text { Igloo Area) (Phase 5) } \\
\text { Old Acid Waste Line Outfall }\end{array}$ \\
\hline $\begin{array}{l}\text { AL-SA-13 } \\
\text { (South Coyote } \\
\text { Test Field) }\end{array}$ & $\begin{array}{l}15 . \\
28 . \\
47 . \\
67 . \\
69 . \\
72 .\end{array}$ & $\begin{array}{l}\text { Trash Pits (Frustration Site) } \\
\text { Mine Shafts } \\
\text { Doomed Bunker Outfall } \\
\text { Frustration Site } \\
\text { Firing Pits (near USGS) } \\
\text { Operation Beaver Site }\end{array}$ \\
\hline
\end{tabular}




\section{APPENDIX C}

SAMPLE COLLECTION AND ANALYSIS

C. $1 / 2$ 


\section{C.1 SAMPLE COLLECTION FOR RADIOACTIVE EFFLUENTS}

Samples are gathered and stored in accordance with methods described in DOE/EP-0023 (DOE, 1981). These procedures have been documented in the SNL, Albuquerque Environmental Monitoring Manual (SNL, 1986). Native vegetation, soil, and water samples are collected annually at the end of the growing season. TLDs are exchanged quarterly (Table C-1).

Vegetation. Native vegetation samples are collected in late summer from a $9-m^{2}$ area at each sample location. Since the native desert vegetation is sparse, a sample includes a mixture of species, with grass species predominating. Each sample weighs approximately $0.5 \mathrm{~kg}$ and consists of stems and leaves representative of the species at each site. Consequently, radionuclide concentrations for vegetation include variability due to species uptake, retention, or deposition as well as location. Three samples are collected and composited at each location to ensure an adequate sample size for subsequent analysis. Replicate samples consisting solely of grasses were collected at each of three adjacent sample plots in order to estimate variability due to location. Each vegetation sample is cut and blended prior to radiochemical analysis for tritium and gamma spectrum analysis.

Water. Water samples are collected in acid-cleaned, plastic containers that have been rinsed in distilled water. Replicate samples of approximately $3.8 \mathrm{~L}$ of water are collected at each water sampling location. One sample is acidified immediately to 10 percent by volume with $2 \mathrm{~N} \mathrm{HNO}_{3}$ and is used for total water radiochemical analysis.

The second sample is filtered immediately and the water is then acidtreated to prevent plating of any radionuclides on the container walls. A radiochemical analysis for gross $\alpha$, gross $\beta$, gamma spectrum analysis, uranium, and tritium are then performed on the water and filter samples.

Soi1. Soil samples are randomly collected from the same $9-\mathrm{m}^{2}$ quadrat as the vegetation samples. Three $100-\mathrm{cm}^{2}$ samples of the top $5 \mathrm{~cm}$ of soil are collected and composited at each station. Each soil sample is dried, ballmilled, and sieved prior to a $137 \mathrm{Cs}$ and uranium analysis. A separate aliquot is used for tritium analysis following EPA-recommended procedures. Replicate (three) samples are collected at three or more locations to determine sample variability. 


\section{2 RADIOCHEMICAL ANALYSIS}

Vegetation. Aliquots of the vegetation samples are taken for each radiochemical analysis. One aliquot of vegetation is air-dried to reach a constant dry mass, finely ground up, and then placed in a 500-m1 Marinelli beaker for gamma spectrum analysis. A 70-g sample (250-m1 calibration geometry), is used for each gamma spectrum analysis. A second (100-g) aliquot of vegetation is heated with cyclohexane in a 1,000-m1 distillation flask, and the water is collected in a Barrett trap. The water collected in the trap is analyzed for $3 \mathrm{H}$ with a liquid scintillation detector using a $1-\mathrm{m} 1$ sample volume.

So11. Soil samples are analyzed for uranlum by leaching a $2-g$ aliquot with mixed acids ( $\mathrm{HNO}_{3} / \mathrm{HF}$ ) and diluting with water to a $10-\mathrm{ml}$ volume to extract uranium and other acid-soluble metals. A $0.1-\mathrm{ml}$ aliquot of acid solution is diluted to $10 \mathrm{ml}$ with $2 \mathrm{~N} \mathrm{HNO}_{3}$. Fifteen milliliters of aluminum nitrate and $10 \mathrm{ml}$ of ethyl acetate are added and mixed for $10 \mathrm{~min}$ to selectively extract uranium into the organic phase. Three $0.1 \% \mathrm{ml}$ aliquots are then fused with an NaF/LiF flux and tested by fluorescence.

Percent Moisture. Percent moisture for soil samples is determined in one of two ways. A moisture balance is used which provides a direct readout of percent moisture in $10 \mathrm{~g}$ of soil. An alternative method is to dry $10 \mathrm{~g}$ of soil at $110^{\circ} \mathrm{C}$ until a constant dry weight is reached. This weight is then used in calculating percent moisture.

Gamma Spectrum Analysis. Water, soil, and vegetation samples are analyzed according to American National Standards Institute/Institute of Electrical and Electronics Engineers (ANSI/IEEE) Standard 680-1978 (Standard Techniques for Determination of Germanium Semiconductor Detector Gamma Ray Efficiency Using a Standard Marinelli Beaker Geometry). They are analyzed for gamma-emitting radionuclides by placing approximately $450 \mathrm{~g}$ of water, $862 \mathrm{~g}$ of soil, or $70 \mathrm{~g}$ of vegetation in 500-ml Marinelli beakers and counting for $1,000 \mathrm{~min}$ ( $100 \mathrm{~min}$ for soil) by using high-efficiency, highresolution intrinsic $\mathrm{Ge}$ or $\mathrm{Ge}$ ( $\mathrm{Li}$ ) detectors and multi-channel analyzers. The vegetation samples are analyzed in a 250-ml geometry. The detectors are calibrated and checked routinely by using either a mixed radionuclide standard obtained from the National Bureau of Standards (NBS) or by using a standard for specific radionuclides traceable to NBS. The data are analyzed by computer software developed by Canberra Industries.

Water. Water samples are further analyzed for gross alpha-beta activity by evaporating an aliquot of water ( $100 \mathrm{ml}$ for alpha analysis; $400 \mathrm{ml}$ for beta analysis) on a $5-\mathrm{cm}$ diameter stainless steel planchet and counting for 100 min by using a low-background, gas-proportional detector. The detector is calibrated and checked routinely by using radionuclide standards traceable to NBS. 


\section{3 EXTERNAL PENELRATING RADIATION}

Thermoluminescent Dosineters (TLDS) are placed at 33 locations the type of TLD phosphot used fs tff in chip form All dosimeters are placed in open areas over soll substrates l m above ground level. A mintium of five TLDs are placed at each location in order to get an estimate of the variablity in TLD response at that location TLD are exohanged on a quarterly basis. A dedicated set of environmental TLDs is maineaired fot this program.

A11 TLDs are annealed at $400^{\circ} \mathrm{C}$ for 1 hr prior to field placement. Transit controls are used to document additional exposulre recelved durling transit from SNit, Albuquerque to fiald locations The TLD readout equipment is calibrated by exposfng TLD to $0,10,20,30$, and 50 mk of $137 \mathrm{Cs}$ midway through each quarterly field cyale Ten This ate exped at each level.

Procedures used in the SNL, Albuquerque envimantalosinetry program have been documented in the Dosimetry Procedures Manual (Federal Register, 1988). 


\section{C.4 SAMPLE COLLECTION AND ANALYSIS FOR GROUNDWATER SAMPLES}

Sampling protocol is as follows. Water level measurements are taken using a chalked tape. After four to 10 well volumes have been evacuated from each we11, pumping is continued until $\mathrm{pH}$, temperature, and conductivity stabilize. The $\mathrm{pH}$ is considered stable when three consecutive measurements agree within $0.2 \mathrm{pH}$ units. Temperature is considered stable when three consecutive measurements agree within $0.2^{\circ} \mathrm{C}$. Conductivity is considered stable when two consecutive measurements agree within 10 micromhos. All groundwater samples are collected and preserved as described in Table C- 2 . Organic sample bottles are filled with a restricted water flow to minimize splashing which would volatilize low molecular weight compounds. Volatile aromatic organics are sampled by filling the bottle until a miniscus forms above the lip of the bottle to ensure no headspace. The concern is that the volatile materials will escape into the headspace and rasult in an erronecus reading. Because of the depth of the groundwater wells, dissolved carbon dioxide volatilizes when the samples are brought to the surface. The evolving carbon dioxide inevitably results in a headspace in the samples. This phenomena is documented in the field logs. The U.S. Environmental Protection Agency (EPA) is reviewing the significance of headspace in samples containing organics.

For analysis, analytical methods described in USEPA (1982) and USEPA (1983) are used. If a method is not available in either of the above, an appropriate method from one of the standard references are used.

Inorganic analyses is performed primarily using Inductively Coupled Plasma Emission Spectrometry (ICP), Ion Chromatography, and Graphite Furnace Atomic Absorption (GFAA). Organic analyses are performed primarily using Gas Chromatography and GC/MS.

\section{SOURCES OF ERROR}

The purpose of the statistical testing for changes in groundwater parameter values over time is to utilize a methodology that can quantitatively show a significant change at a specified level. The identification of a significant change is not in itself a confirmation of a release from the Chemical Waste Landfill (CWL) reaching the groundwater. One must review the data, the sampling and analytical methods, and the assumptions for the statistical tests in order to confirm that the statistical change represents a true change.

\section{$\mathrm{pH}$}

Since relatively small changes in parameter values may show a significant change, the data must reflect similar methods for collection and analysis, including calibration methods and corrections for changes in conditions affecting the measurement.

A review of the field data collection logs reveals that all pH measurements were made with a field $\mathrm{pH}$ instrument. Potential sources of error include 
temperature, gas exchange and suspension effects. The meter was calibrated in the field using standard buffer solutions. A potential source of error for the $\mathrm{pH}$ measurements was thought to be in the calibration procedure if the buffer solutions were at a different temperature than the groundwater being measured. A review of the sensitivity of $\mathrm{pH}$ to temperature changes shows that the measurement is somewhat insensitive to temperature changes. Standard buffer solutions in the $\mathrm{pH}$ range near 7 will have a variation in $\mathrm{pH}$ of 0.02 to 0.03 units over a temperature range of 10 to $50^{\circ} \mathrm{C}$. The field measurements of temperature of the solutions measured for $\mathrm{pH}$ ranged from 15 to $30^{\circ} \mathrm{C}$.

Since it is not practical to make in-situ measurements of the groundwater $\mathrm{pH}$, the sample must be brought to the surface. Two methods have been used to evacuate and sample the wells: pumping with a small diameter piston pump and bailing. The potential for having gas exchange occurring starts when the groundwater flows into the well bore and continues until the groundwater sample is measured at the surface. The use of the piston pump to purge and sample the well reduces the contact of the groundwater with the atmosphere. Generally, the water is pumped into a sample container, and the $\mathrm{pH}$ is measured as soon as practical. Water collected by bailing in the well bore is generally surged and mixed with the atmosphere existing in the wellbore above the water. The water within the baile- is then removed and placed into a bucket. Both wells MWl and BWl are two inch wells that do not allow a pump to pass restricted zones within the casing. Thus, these two wells must be bailed for purging and sampling. The water in wells MW1 and BW1 was extremely turbid; therefore, the suspension was allowed to settle for approximately $15 \mathrm{~min}$ prior to bailing. The loss or gain of certain volatile constituents that participate in controlling the solution $\mathrm{pH}$, such as carbon dioxide and hydrogen sulfide, will alter the pH as a time-dependent phenomenon. The absorption of $\mathrm{CO}_{2}$ into the solution will generate carbonic: id, release hydrogen ions from carbonatebicarbonate reactions, and cause a decrease in the $\mathrm{pH}$. The equilibrium $\mathrm{pH}$ due to the partial pressure of atmospheric $\mathrm{CO}_{2}$ is about five (Garrels and Christ, 1965). Currently, the magnitude of this potential source of error for groundwater is not understood; however, a standard geochemistry textbook reveals a change of $1.5 \mathrm{pH}$ units for a deaerated alkaline solution allowed to absorb atmospheric constituents (Garrels and Christ, 1965).

The effects of mineral suspensions on the results of a pH determination will also be an important source of error. Carbonate minerals such as calcite (limestone) and arragonite (caliche) will hydrolyze in solution releasing carbonate. The carbonate will remove hydrogen ions from the solution using the same carbonate-bicarbonate reaction noted above and act to increase the $\mathrm{pH}$. The equilibrium $\mathrm{pH}$ die to calcite is approximately 9.5 (Garrels and Christ, 1965).

The negative charges on the surfaces of clays will also be capable of removing hydrogen ions from solutions and increasing the $\mathrm{pH}$. A small laboratory experiment was performed to determine the effect a clay found near the water table during the drilling of in well MWlA, just $50 \mathrm{ft}$ to the west of MWl, on the $\mathrm{pH}$ of distilled water. The results showed that the 
addition of small amounts of the clay would linearly increase the $\mathrm{pH}$ from 7.2 to 8.9. Due to the large screen size and the necessity to bail MW1 for purging and sampling, well MWl showed very high turbidity levels. During the February 1988 sampling event a measurement of the turbisty revealed a value of 8,400 NTU for MW1 and 3,100 for BW1.

\section{Specific Conductivity}

All data for the specific conductance parameter was found in the field data collection logs. These data were not corrected for temperature. Temperature differences of $1^{\circ} \mathrm{C}$ can lead to about a 2 -percent difference in the value of specific conductance. All field data were corrected to $25^{\circ} \mathrm{C}$.

\section{Statistical Assumptions}

The statistical procedure used to test for significant change in this report was specified in the groundwater monitoring regulations. A critical review of the assumptions that support this statistical test must be performed to see if the assumptions are upheld. If not, the validity of the conclusion of the statistical test must be questioned.

The CABF method was developed to analyze independent samples with unequal population variances. There has been much criticism of this method due to the inherently high false positive rate that the EPA issued a final rule October 11 , 1988 that amended the statistical tests required for groundwater monitoring (Federal Register, 1988). The rule specifies five other tests, more appropriate to groundwater monitoring than the CABF mathod, for permitted facilities under Part 264. The EPA felt that most land disposal facilities would have permits by November 1988, and did not feel the need to modify the interim status regulations of Part 265.

Two sources have identified potential problems with using the CABF as a method to detect releases from a hazardous waste management unit. The EPA Technical Enforcement Guidance Document discusses t-tests available for facilities unde: interim status (EPA, 1986). In that document, the authors detail an alternative t-test, the Averaged Replicate (AR) t-test, that is recommended as more appropriate than the CABF t-test for groundwater monitoring.

The October, 1988 Final Rule on statistical methods for groundwater monitoring points out several reasons for rejecting the CABF method: (1) the replicate sainling method required by the regulations is not appropriate for the CABF method, (2) the CABF does not adequately consider the number of comparisons that must be made under the regulations, and ( 3 ) the CABF does not control for seasonal variations in parameter values (Federal Register, 1988). Concern arose regarding potential false positive errors and false negative errors exceeding reasonable rates for a regulated concern. As a result, four specific statistical tests, not including the CABF or the AR t-tests, and an option for the owner/ operator to propose any other test were issued as a final rule on October 11, 1988. Until SivL, Albuquerque, certifies closure of the CWL and becomes a permitted facility 
requiring post-closure monitoring, the statistical tests must remain $t$ tests as specified in 40 CFR Part 265 for interim status facilities or by the New Mexico Environmental Improvement Division (NMEID). 


\section{C.5 SAMPLE COLLECTION AND ANALYSIS FOR WASTEWATER SAMPLING}

The sampling methods and procedures are detailed in the SNL, Albuquerque Wastewater Sampling Plan Table C-3. Samples were collected at five locations (Table 6-2). Methods used for sampling grab and composite samples are listed in Tables $\mathrm{C}-4$ and $\mathrm{C}-5$, respectively. Analytic;al methods and detection limits are listed in Table D-2 for each paramater. Monitoring requirements for each of the permitted stations may be separated into daily, monthly and yearly requirements. These requirements are summarized in Table C-3 to C-8. Details about the parameters to be analyzed and the permit limits for each parameter are contained in Tables C-4 to C-8. Pollutants noted with an asterisk (*) an Tables C-4 to C-8 are analyzed for in samples collected each month.

The City of Albuquerque permits require that all parameters listed in Tables C-4 to C-8 be analyzed once each year. Stations WW001, WW004, WW005, WW006, and WW007 are monitored continuously for pH and flow. Station WW003 is monitored for $\mathrm{pH}$ in each of two grab samples taken during the four sampling days every month. Table C-9 describes the analytical methods used for each SNL permitted wastewater sampling station. 


\section{C.6 SAMPLE COLLECTION AND ANALYSIS FOR AREA IV LAGOONS}

Approved Discharge Plan DP.530 requires quarterly measurement of water level in each of the lagoons and semi-annual sampling for the water-quality parameters listed in Table 6-5. The limits for these parameters are also shown in Table $6-5$.

Samples from the lagoons are collected and preserved in accordance with guidance provided in the Handbook for Sampling and Sample Preservation of Water and Wastewater (EPA-600/4-82-029). Organic and inorganic fractions are collected as surface grab samples using a wide-mouthed borosilicate glass jar. Purgeable and extractable organic fractions are aliquotted first. Metal and wet-chemistry fractions are passed through a 0.45 -micron cellulose acetate membrane filter before placement into prepreserved sample containers. All samples are iced after collection and during shipment.

Analyses conducted on all samples include (1) priority pollutant analysis for purgeable and base neutrals, (2) major cations and anions, and (3) total dissolved solids (TDS). Analyses are performed in accordance with U.S. Environmental Protection Agency (EPA) recommended analytical procedures for aqueous samples. 
Table C-1. Sampling Frequencles and Types of Analysis for Radioactive Environmental Monitoring Program

\begin{tabular}{|c|c|c|c|c|c|}
\hline \multirow[b]{3}{*}{ Parameter } & \multicolumn{5}{|c|}{ Sample Media } \\
\hline & \multirow[b]{2}{*}{ Vegetation } & \multirow[b]{2}{*}{ Soil } & \multicolumn{2}{|c|}{ Water } & \multirow[b]{2}{*}{ TLDs } \\
\hline & & & Total & $\begin{array}{l}\text { Filters } \\
\text { Filtrate }\end{array}$ & \\
\hline Number of Locations & 23 & 23 & 10 & 10 & 32 \\
\hline Number of Samples & 31 & 31 & 10 & 10 & 128 \\
\hline Sample Frequency & Annual & Annual & Annual & Annual. & Quarterly \\
\hline \multicolumn{6}{|l|}{ Analysis Performed } \\
\hline Gross $\alpha$ & & & $\mathrm{X}$ & $x^{* *}$ & \\
\hline Gross $\beta^{-}$ & & & $\mathrm{X}$ & $x^{\star *}$ & \\
\hline$U_{\text {tot }}$ & & $\mathrm{X}$ & $\mathrm{x}$ & $\mathrm{X}$ & \\
\hline Gamma Spec. & $\mathrm{x}$ & $\mathrm{X}$ & $\mathrm{X}$ & $\mathrm{X}$ & \\
\hline Tritium & $\mathrm{X}$ & $\mathrm{X}$ & $\mathrm{X}$ & $\mathrm{X}$ & \\
\hline $8 \mathrm{H}_{2} \mathrm{O}$ & $\mathrm{X}$ & $\mathrm{x}$ & & & \\
\hline TLD & & & & & $\mathrm{X}$ \\
\hline Number of Analysis & 93 & 93 & 50 & 106 & 125 \\
\hline $\begin{array}{l}{ }^{*} \text { These filter sample } \\
\text { water for selected } \\
{ }^{*} \text { Analysis performed } \\
\text { (filtrate). }\end{array}$ & $\begin{array}{l}\text { s are for an } \\
\text { analysis. } \\
\text { on suspended }\end{array}$ & $\begin{array}{l}\text { lysis of } \\
\text { solids } 1\end{array}$ & additic & $\begin{array}{l}\text { solids as } \\
\text { to filtere }\end{array}$ & $\begin{array}{l}\text { well as } \\
\text { d water }\end{array}$ \\
\hline
\end{tabular}




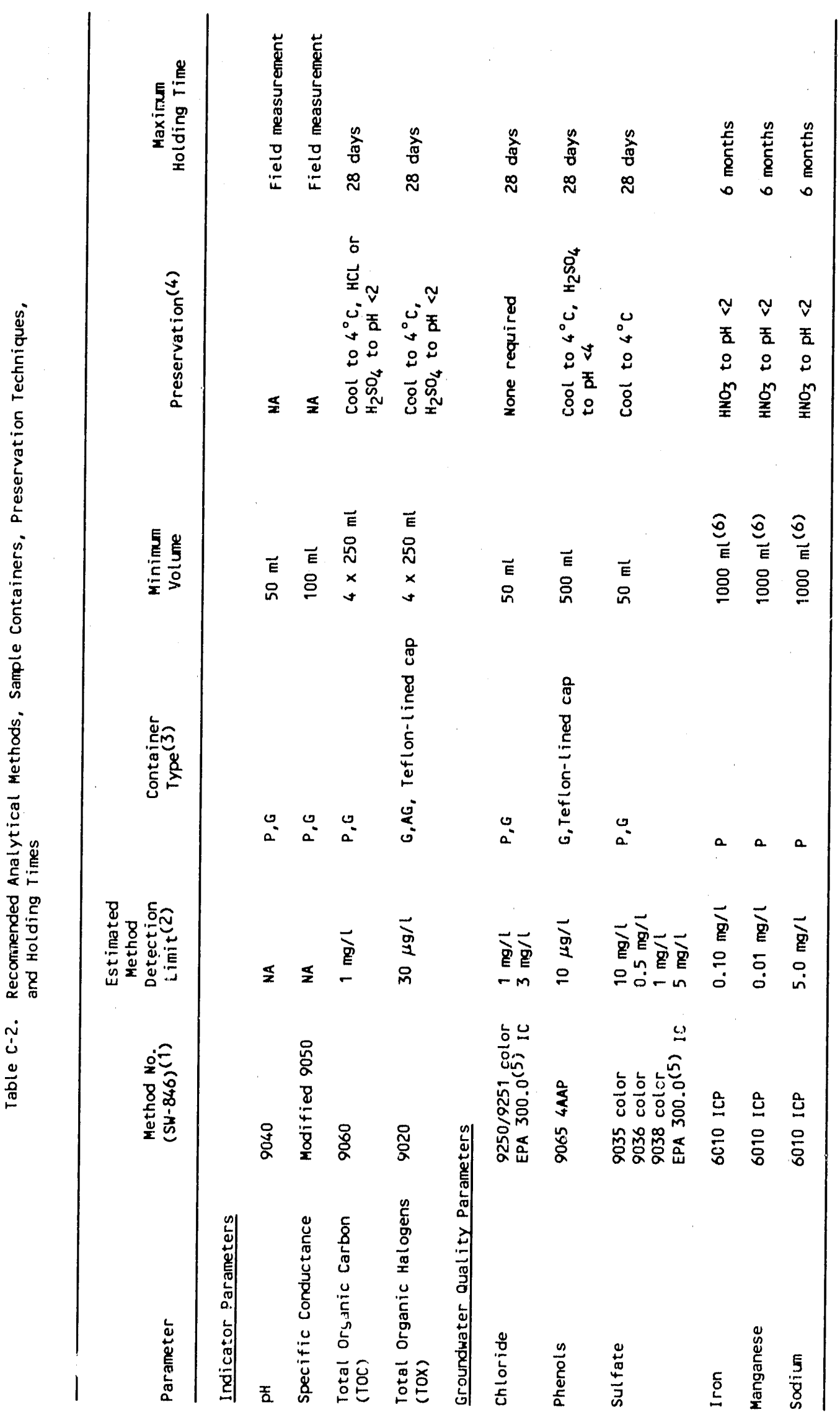




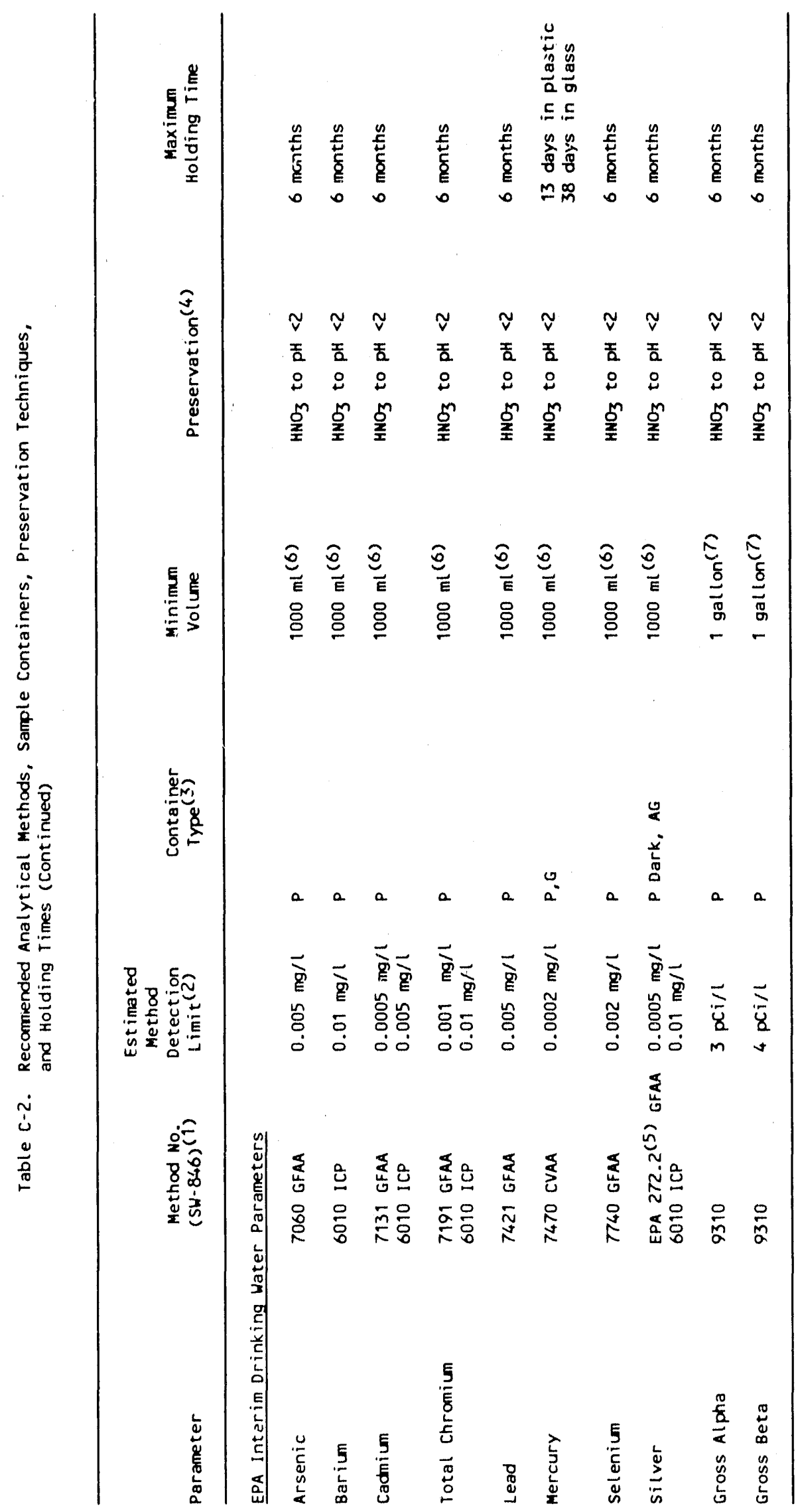




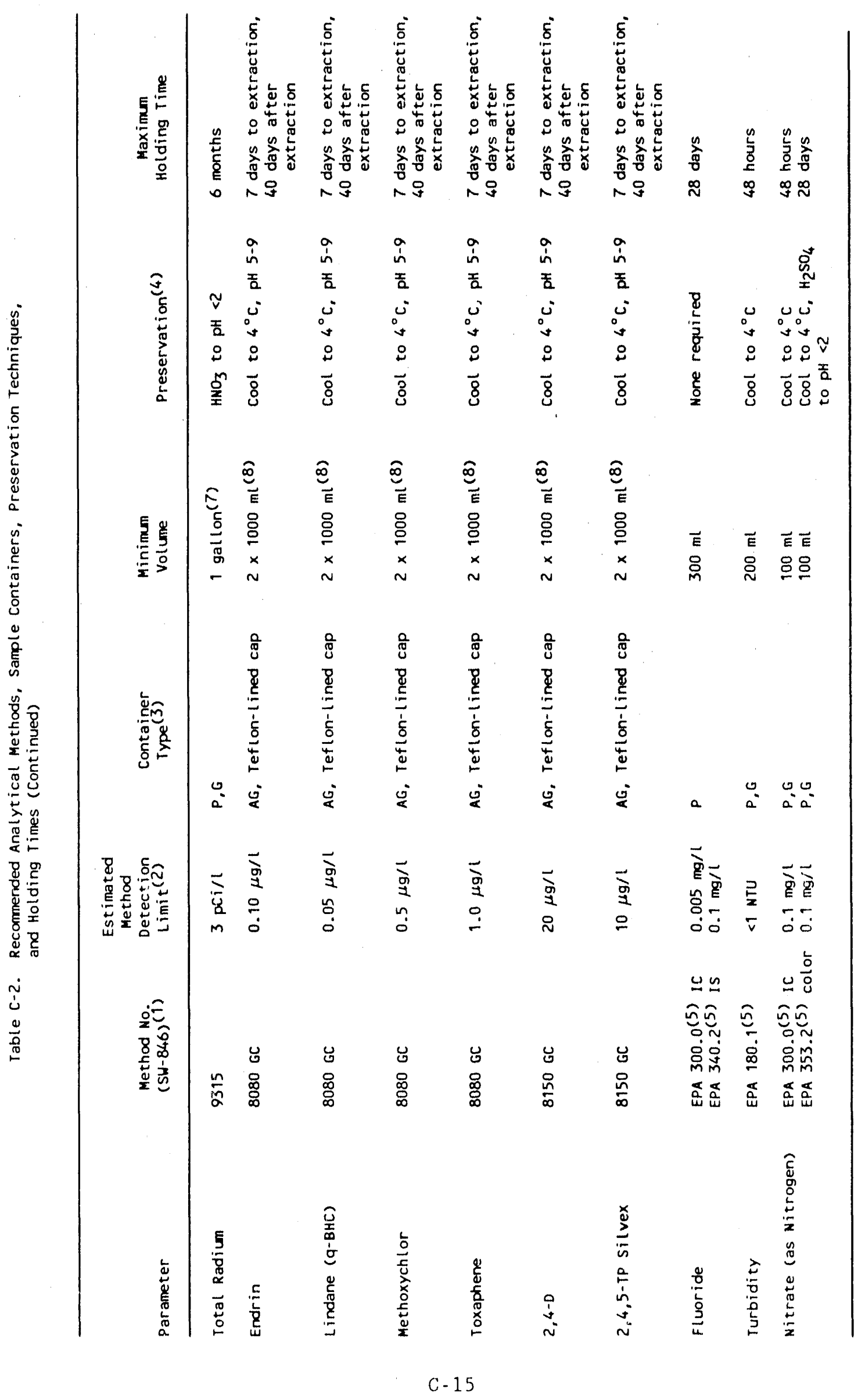




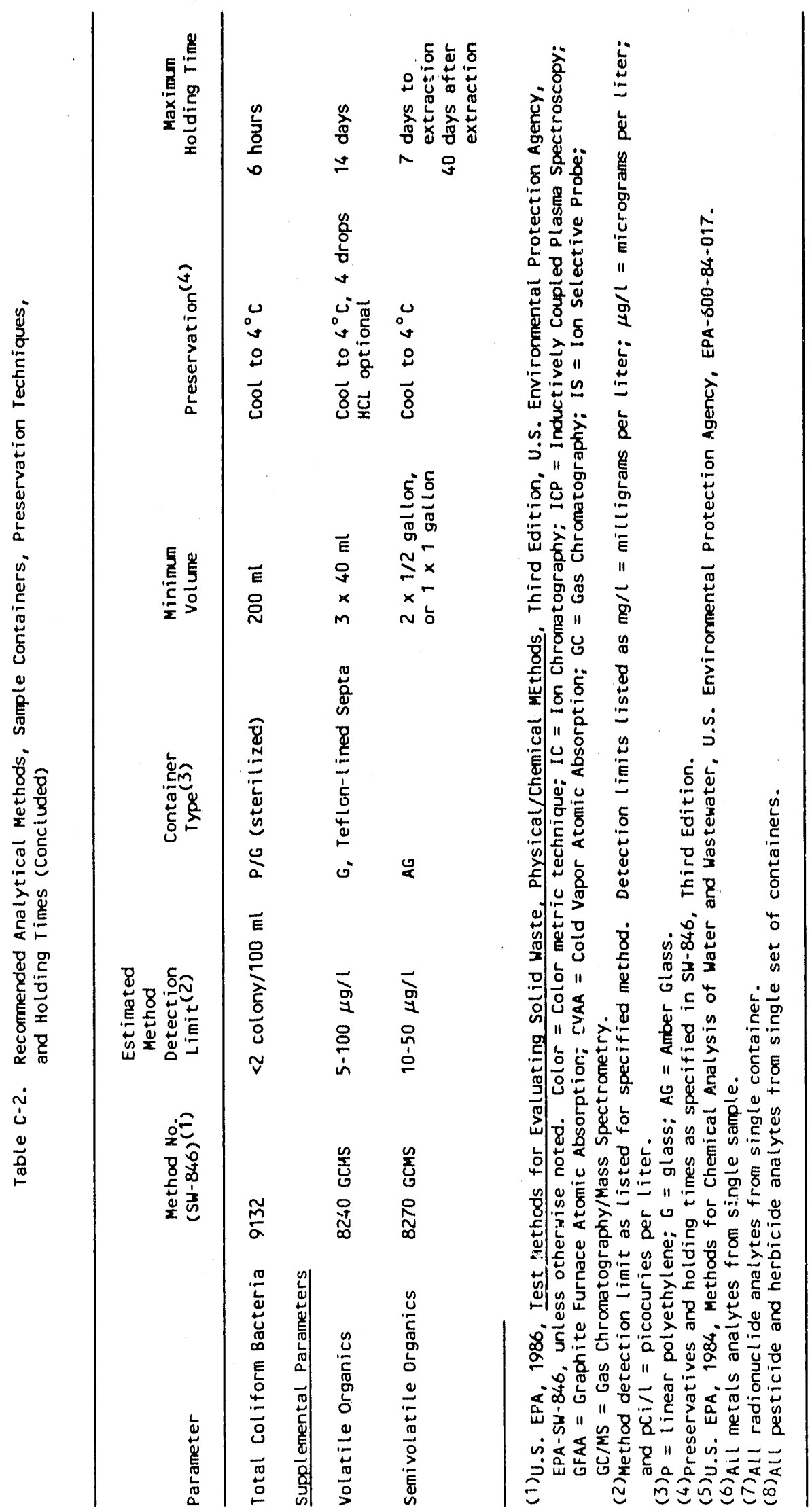


Table C-3. Summary of Characteristics for SNL, Albuquerque, Waste Water Sampling Stations

\begin{tabular}{|c|c|c|c|}
\hline $\begin{array}{l}\text { Station } \\
\text { Number }\end{array}$ & Frequency & Flumes & $\begin{array}{c}\text { Flow Meter and } \\
\text { Sampling Equipment }\end{array}$ \\
\hline WW001 & $4 \mathrm{x} / \mathrm{mo}$ & 3" Parsha11 & $\begin{array}{l}\text { ISCO } 24 \text { Flow leter } \\
\text { ISCO } 2700 \mathrm{R} \text { Sampler } \\
\text { Leeds and Northrop pH } \\
\text { Analyzer system }\end{array}$ \\
\hline WW003 & $4 \mathrm{x} / \mathrm{mo}$ & none & ISCO 2700 Sampler \\
\hline WW004 & $4 \mathrm{x} / \mathrm{mo}$ & 2" Parshall & $\begin{array}{l}\text { ISCO } 2400 \text { Flow Meter } \\
\text { ISCO } 2700 \text { R Sampler } \\
\text { Leeds and Northrop pH } \\
\text { Analyzer }\end{array}$ \\
\hline WW005 & $4 \mathrm{x} / \mathrm{mo}$ & 3" Parshall & $\begin{array}{l}\text { ISCO } 2400 \text { Flow Meter } \\
\text { ISCO } 2700 \text { R Sampler } \\
\text { Leeds and Northrop pH } \\
\text { Analyzer system }\end{array}$ \\
\hline WW006 & $4 \mathrm{x} / \mathrm{mo}$ & 6" Parshal1 & $\begin{array}{l}\text { ISCO } 2400 \text { Flow Meter } \\
\text { ISCO } 2700 \text { R Sampler } \\
\text { Leeds and Northrop pH } \\
\text { Analyzer system }\end{array}$ \\
\hline WW007 & $4 \mathrm{x} / \mathrm{mo}^{\prime}$ & $45^{\circ} \mathrm{V}$-Notchweir & $\begin{array}{l}\text { ISCO } 2440 \text { Flow Meter } \\
\text { ISCO } 2700 \text { R Sampler } \\
\text { Leeds and Northrop pH } \\
\text { Analyzer system }\end{array}$ \\
\hline
\end{tabular}


1989 ENVIRONMENTAL MONITORING REPORT, SANDIA NATIONAL LABORATORIES, ALBUQUERQUE

Table C-4. Pollutant Concentration Limits, Waste Water

Discharge Permit 2069A, Sampling Station WW001

\begin{tabular}{llll}
\hline \multicolumn{1}{c}{ Pollutant } & $\begin{array}{c}\text { 4-Day } \\
\text { Average }\end{array}$ & $\begin{array}{c}1 \text {-Day } \\
\text { Average }\end{array}$ & $\begin{array}{c}\text { Grab } \\
\text { Maximum }\end{array}$ \\
\hline Phenols (ug/1) & 1000 & 2000 & 4000 \\
Silver (ug/1) & 2000 & 3400 & 8000 \\
Arsenic (ug/1) & 500 & 800 & 2000 \\
Barium (ug/1) & 5000 & 7500 & 20000 \\
Cadmium (ug/1)* & 1000 & 1700 & 4000 \\
Cyanide (mg/1)* & 2 & 3.8 & 8 \\
Chromium (ug/1) & 5000 & 8800 & 20000 \\
Copper (ug/1)* & 6000 & 10200 & 24000 \\
Mercury (ug/1) & 20 & 40 & 100 \\
Manganese (ug/1) & 5000 & 7500 & 20000 \\
Nicke1 (ug/1) & 3000 & 4700 & 12000 \\
Oil/Grease (mg/1) & 50 & 75 & 150 \\
Lead (ug/1)* & 800 & 1200 & 3200 \\
pH** & & & $>5,<11$ \\
Selenium (ug/1) & 500 & 800 & 2000 \\
Temperature ${ }^{\circ}$ & & & $<140$ \\
Total Metals (Cu, Cr) & 1000 & 15400 & 40000 \\
Total Toxic Org. & 2100 & 3200 & 5000 \\
Zinc (ug/1)* & 7000 & 11300 & 28000 \\
\hline
\end{tabular}


Table C-5. Pollutant Concentration Limits, Waste Water Discharge Permit 2069C-2, Sampling Station WW003

\begin{tabular}{llll}
\hline \multicolumn{1}{c}{ Pollutant } & $\begin{array}{c}4 \text {-Day } \\
\text { Average }\end{array}$ & $\begin{array}{c}1 \text {-Day } \\
\text { Average }\end{array}$ & $\begin{array}{c}\text { Grab } \\
\text { Maximum }\end{array}$ \\
\hline Phenols (ug/1) & 1000 & 2000 & 4000 \\
Silver (ug/1)* & 2000 & 3400 & 8000 \\
Arsenic (ug/1) & 500 & 800 & 2000 \\
Barium (ug/1) & 5000 & 7500 & 20000 \\
Cadmium (ug/1)* & 641.025 & 1098.9 & 4000 \\
Cyanide (ug/1)* & 641.025 & 1217.94 & 8000 \\
Chromium (ug/1)* & 5000 & 8800 & 20000 \\
Copper (ug/1)* & 5769.23 & 9615.38 & 24000 \\
Mercury (ug/1) & 20 & 40 & 100 \\
Manganese (ug/1) & 5000 & 7500 & 20000 \\
Nickel (ug/1)* & 2083.33 & 3285.25 & 12000 \\
Oil/Grease (mg/1) & 50 & 75 & 150 \\
Lead (ug/1)* & 732.6 & 1098.9 & 3200 \\
pH** & & & $>5,<11$ \\
Selenium (ug/1) & 500 & 800 & 2000 \\
Temperature ${ }^{\circ} \mathrm{F}$ & & & $<140$ \\
Total Metals (Cu, Cr)* & 1000 & 15400 & 40000 \\
Total Toxic Org. & 2100 & 1365.380 & 5000 \\
Zinc (ug/1)* & 4761.9 & 7692.3 & 28000 \\
\hline
\end{tabular}


Table C-6. Pollutant Concentration Limits, Waste Water Discharge Permit 2069D-2, Sampling Station WW004

\begin{tabular}{llll}
\hline \multicolumn{1}{c}{ Pollutant } & \multicolumn{1}{c}{$\begin{array}{c}\text { 4-Day } \\
\text { Average }\end{array}$} & $\begin{array}{c}1 \text {-Day } \\
\text { Average }\end{array}$ & $\begin{array}{c}\text { Grab } \\
\text { Maximum }\end{array}$ \\
\hline Phenols (ug/1) & 1000 & 2000 & 4000 \\
Silver (ug/1)* & 436.3630 & 781.8180 & 8000 \\
Arsenic (ug/1) & 500 & 800 & 2000 \\
Barium (ug/1) & 5000 & 7500 & 20000 \\
Cadmium (ug/1)* & 371.428 & 985.714 & 4000 \\
Cyanide (ug/1)* & 650 & 860 & \\
Chromium (ug/1)* & 4275 & 6925 & 20000 \\
Copper (ug/1)* & 6000 & 10200 & 24000 \\
Mercury (ug/1) & 20 & 40 & 100 \\
Manganese (ug/1) & 5000 & 7500 & 20000 \\
Nicke1 (ug/1)* & 2975 & 4700 & 12000 \\
Oil/Grease (mg/1) & 50 & 75 & 150 \\
Lead (ug/1)* & 800 & 1200 & 3200 \\
pH** & & & $>5,<11$ \\
Selenium (ug/1) & 500 & 800 & 2000 \\
Temperature ${ }^{\circ}$ F & & & $<140$ \\
Total Metals (Cu, Cr)* & 1000 & 15400 & 40000 \\
Total Toxic Org. & 2100 & 2130 & 5000 \\
Zinc (ug/1)* & 4228.57 & 7457.143 & 28000 \\
\hline & & & \\
*Analyzed monthly. & & & \\
$* *$ Monitored continuous1y. & & & \\
\hline
\end{tabular}


Table C-7. Pollutant Concentration Limits, Waste Water Discharge Permit 2069G, Sampling Station WW007

\begin{tabular}{|c|c|c|c|}
\hline Pollutant & $\begin{array}{l}\text { 4-Day } \\
\text { Average }\end{array}$ & $\begin{array}{l}\text { 1-Day } \\
\text { Average }\end{array}$ & $\begin{array}{c}\text { Grab } \\
\text { Maximum }\end{array}$ \\
\hline Phenols (ug/1) & 1000 & 2000 & 4000 \\
\hline Silver (ug/1) & 2000 & 3400 & 8000 \\
\hline Arsenic (ug/1)* & 500 & 800 & 2000 \\
\hline Barium (ug/1) & 5000 & 7500 & 20000 \\
\hline Cadmi i $(u g / 1) *$ & 1000 & 1700 & 4000 \\
\hline Cyanide (mg/1) & 2 & 3.8 & 8 \\
\hline Chromium (ug/1)* & 5000 & 8800 & 20000 \\
\hline Copper (ug/1)* & 6000 & 10200 & 24000 \\
\hline Fluoride $(\mathrm{mg} / \mathrm{l}) *$ & 30 & 45 & 100 \\
\hline Mercury (ug/1) & 20 & 40 & 100 \\
\hline Manganese (ug/1) & 5000 & 7500 & 20000 \\
\hline Nickel (ug/1)* & 3000 & 4700 & 12000 \\
\hline Oil/Grease (mg/l) & 50 & 75 & 150 \\
\hline $\begin{array}{l}\text { Lead }(1 . \mathrm{g} / 1) * \\
\mathrm{pH} * *\end{array}$ & 800 & 1200 & $\begin{array}{l}3200 \\
>5,<11\end{array}$ \\
\hline Selenium (ug/1) & 500 & 800 & 2000 \\
\hline Temperature ${ }^{\circ} \mathrm{F}$ & & & $<140$ \\
\hline Total Metals (ug/1)* & 10000 & 15400 & 40000 \\
\hline Total Toxic Org. (ug/l) & 2100 & 698 & 5000 \\
\hline Zinc (ug/1) & 7000 & 11300 & 28000 \\
\hline $\begin{array}{l}* \text { Analyzed monthly. } \\
* * \text { Monitored continuously }\end{array}$ & & & \\
\hline
\end{tabular}


Table C-8. Pollutant Concentration Limits, Waste Water Discharge Permit 2069F, Sampling Station WW006

\begin{tabular}{llll}
\hline \multicolumn{1}{c}{ Pollutant } & $\begin{array}{c}4 \text {-Day } \\
\text { Average }\end{array}$ & $\begin{array}{c}\text { 1-Day } \\
\text { Average }\end{array}$ & $\begin{array}{c}\text { Grab } \\
\text { Maximum }\end{array}$ \\
\hline Phenols (ug/1) & 1000 & 2000 & 4000 \\
Silver (ug/1) & 2000 & 3400 & 8000 \\
Arsenic (ug/1) & 500 & 800 & 2000 \\
Bariurn (ug/1) & 5000 & 7500 & 20000 \\
Cadmium (ug/1)* & 1000 & 1700 & 4000 \\
Cyanide (mg/1)* & 2 & 3.8 & 8 \\
Chromium (ug/1) & 5000 & 8800 & 20000 \\
Copper (ug/1)* & 6000 & 10200 & 24000 \\
Mercury (ug/1) & 20 & 40 & 100 \\
Manganese (ug/1) & 5000 & 7500 & 20000 \\
Nickel (ug/1) & 3000 & 4700 & 12000 \\
Oil/Grease (mg/1) & 50 & 75 & 150 \\
Lead (ug/1)* & 800 & 1200 & 3200 \\
pH** & & & $>5,<11$ \\
Selenium (ug/1) & 500 & 800 & 2000 \\
Temperature ${ }^{\circ}$ & & & $<140$ \\
Total Metals (Cu, Cr) & 10000 & 15400 & 40000 \\
Total Toxic Org. & 2100 & 3200 & 5000 \\
Zinc (ug/1)* & 7000 & 11300 & 28000 \\
\hline
\end{tabular}




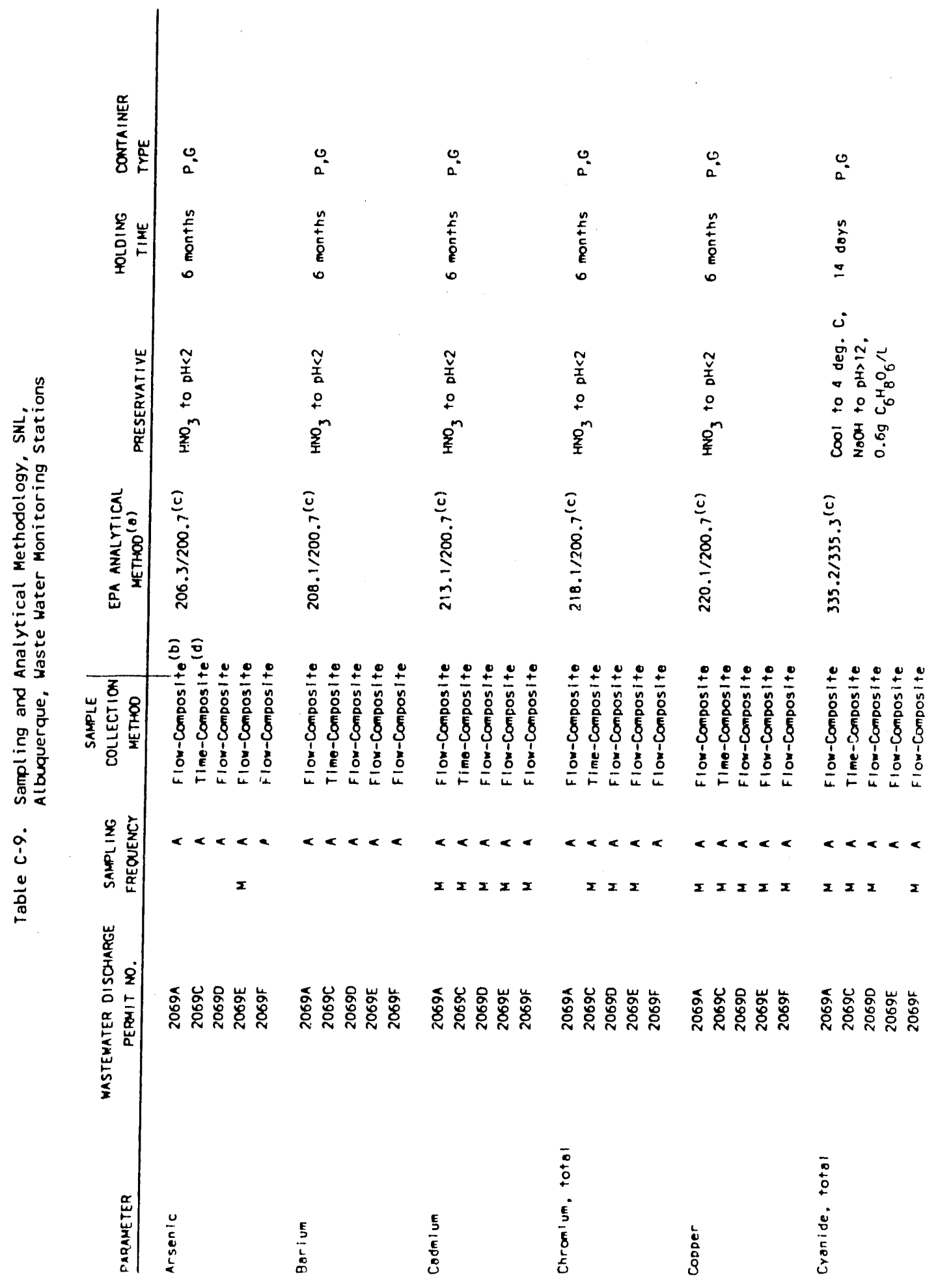




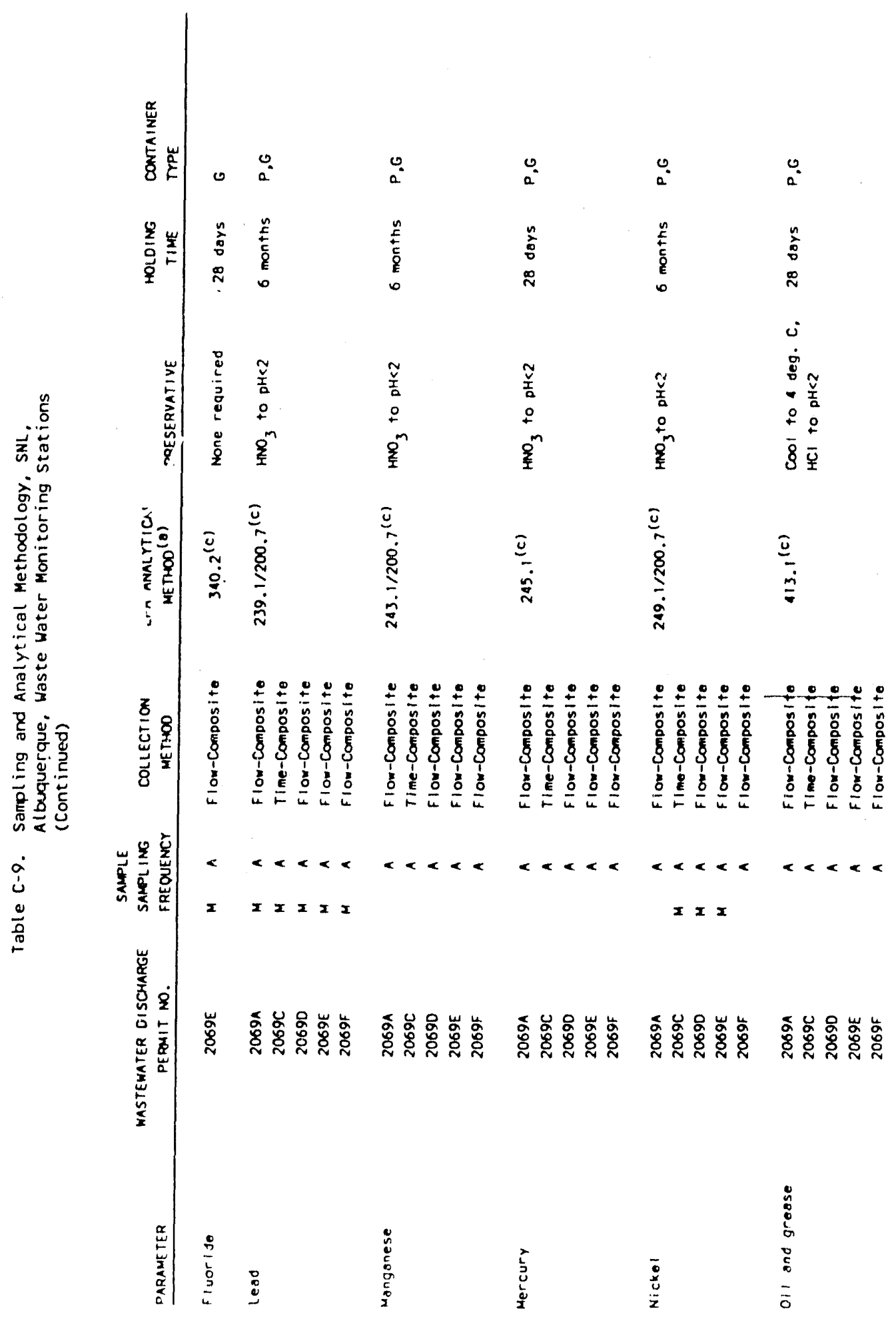




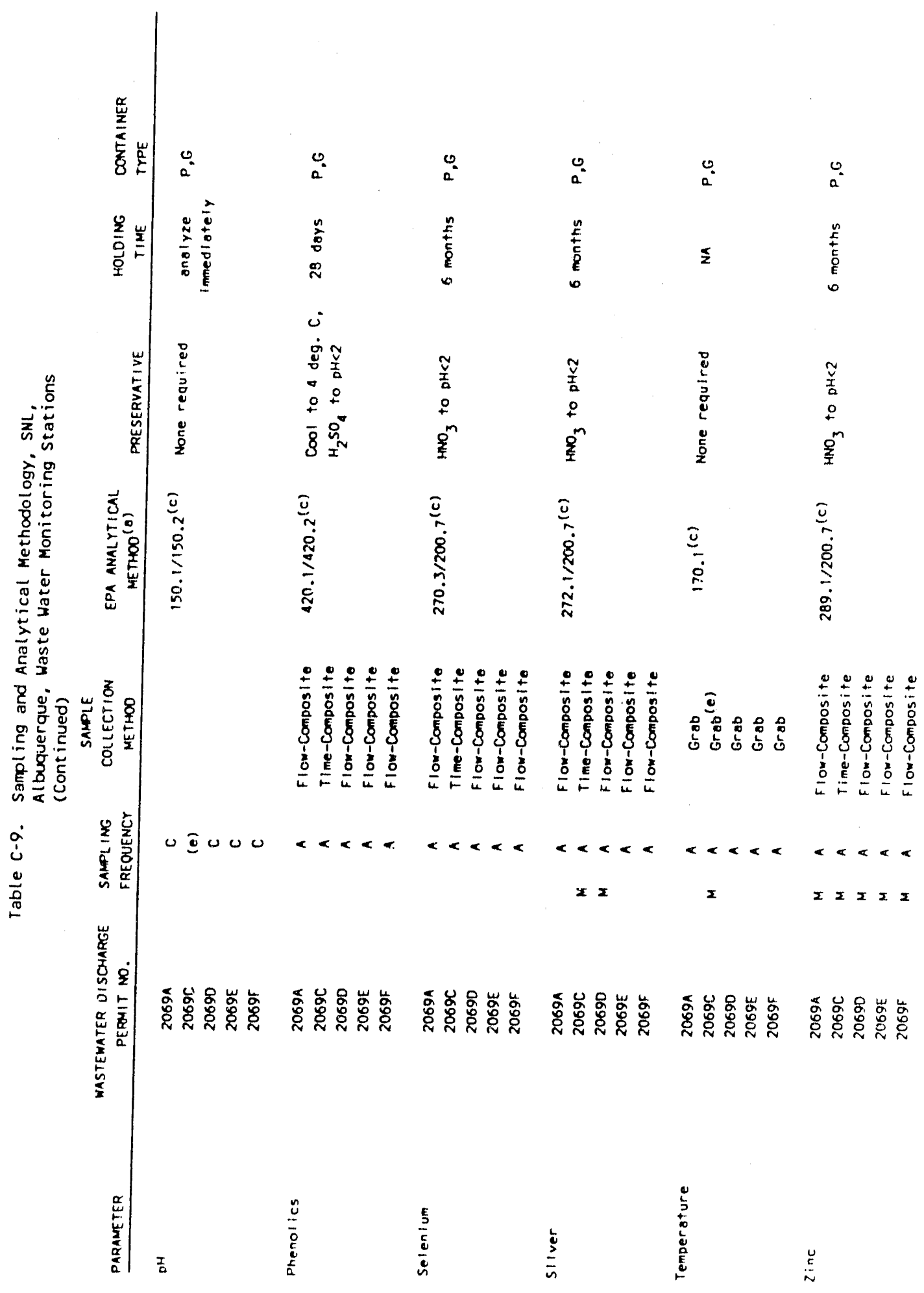



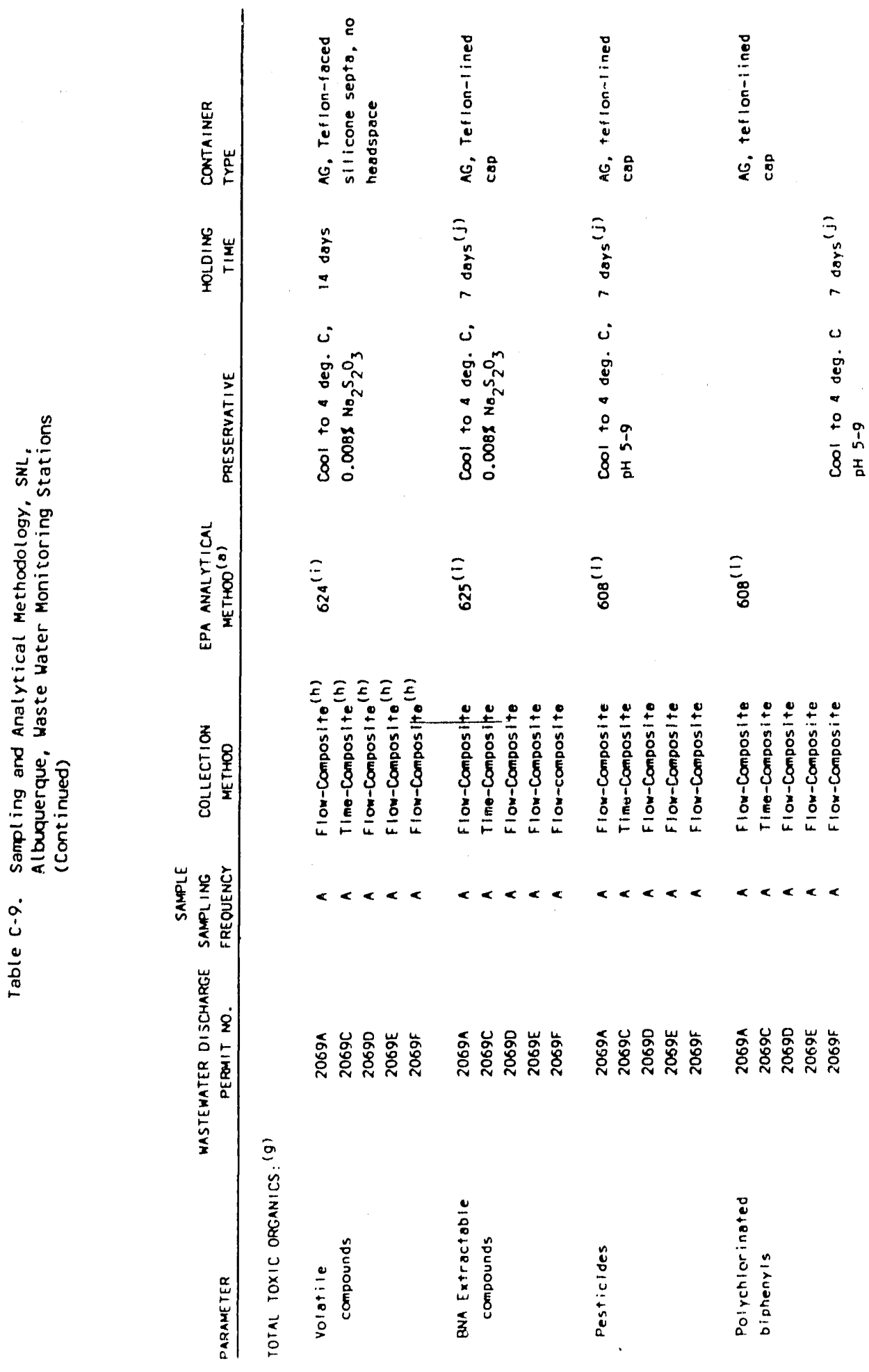


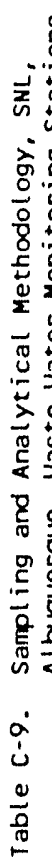

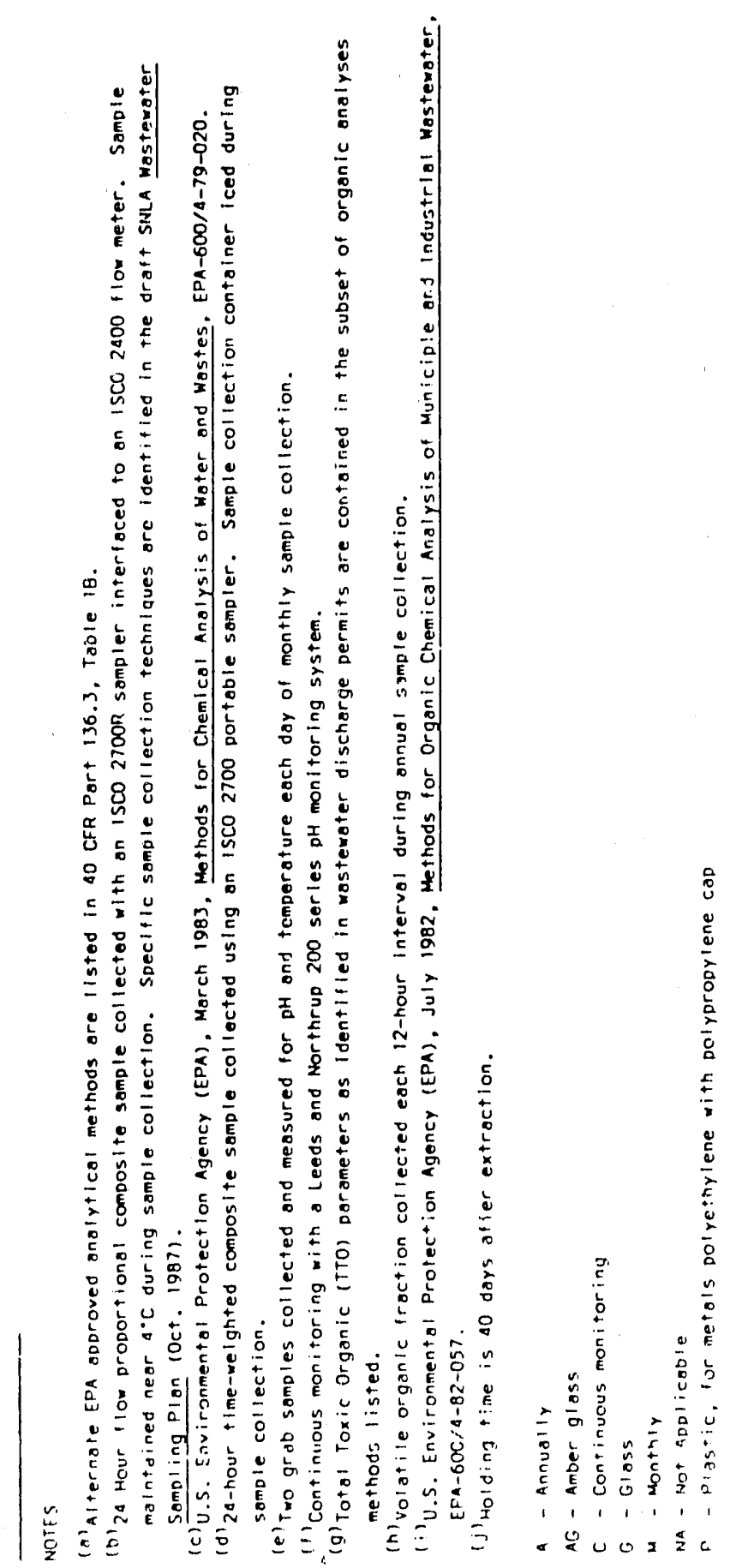




\section{REFERENCES}

Federal Register, Tuesday, October 11, 1988. "40 CFK Part 264, Statistical Methods for Evaluating Ground-water Monitoring from Hazardous Waste Factlities: Final Rule."

Garrels, R. M., and C. L. Christ, 1965. Solutions, Minerals and Equilibria. New York: Harper and Row.x

Sandia National Laboratories (SNL), Albuquerque, 1986. Environmental Monitoring Manual, Sandia National Laboratories, Albuquerque, NM, December 1986.

U.S. Department of Energy (DOE), 1981. "A Guide for Environmental Radiological Surveillance at U.S. Department of Energy Installations," DOE/EP-0023, July.

U.S. Environmental Protection Agency (EPA), 1984. "Methods for Chemical Analysis of Water and Waste Water," EPA-600-84-017.

U.S. Environmental Protection Agency (EPA), 1986. "RCRA Technical Enforcement Guidance Document (TEGD)," OSWER-9950.1, September 1986.

U.S. Environmental Protection Agency (EPA), 1986. "Test Methods for Evaluating Solid Waste, Physical/Chemical Methods, Third Edition," EPA-SW846. 


\section{APPENDIX D}

MINIMUM DETECTION LIMITS

AND

ANALYTICAL METHODS

$D-2 / 2$ 


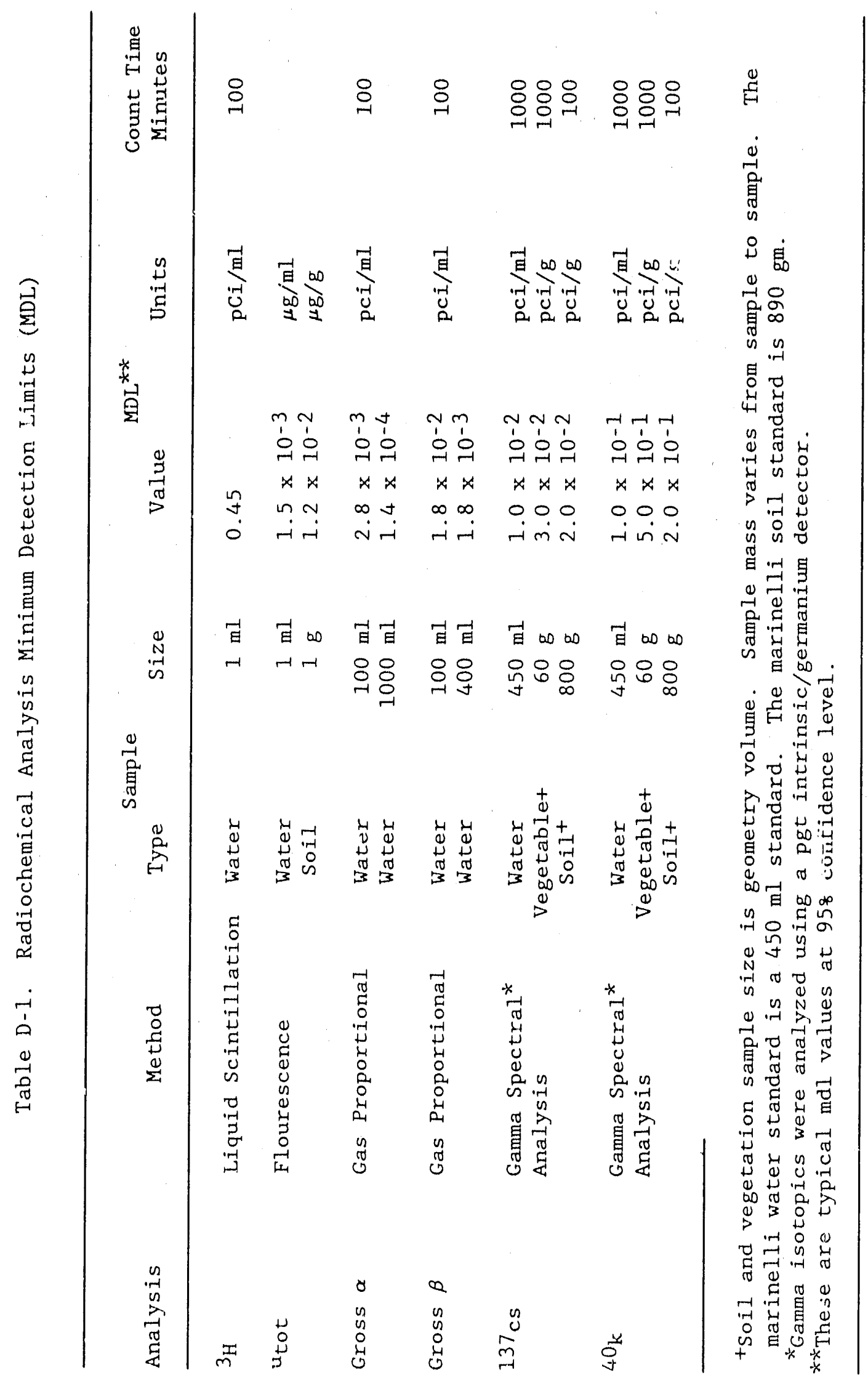




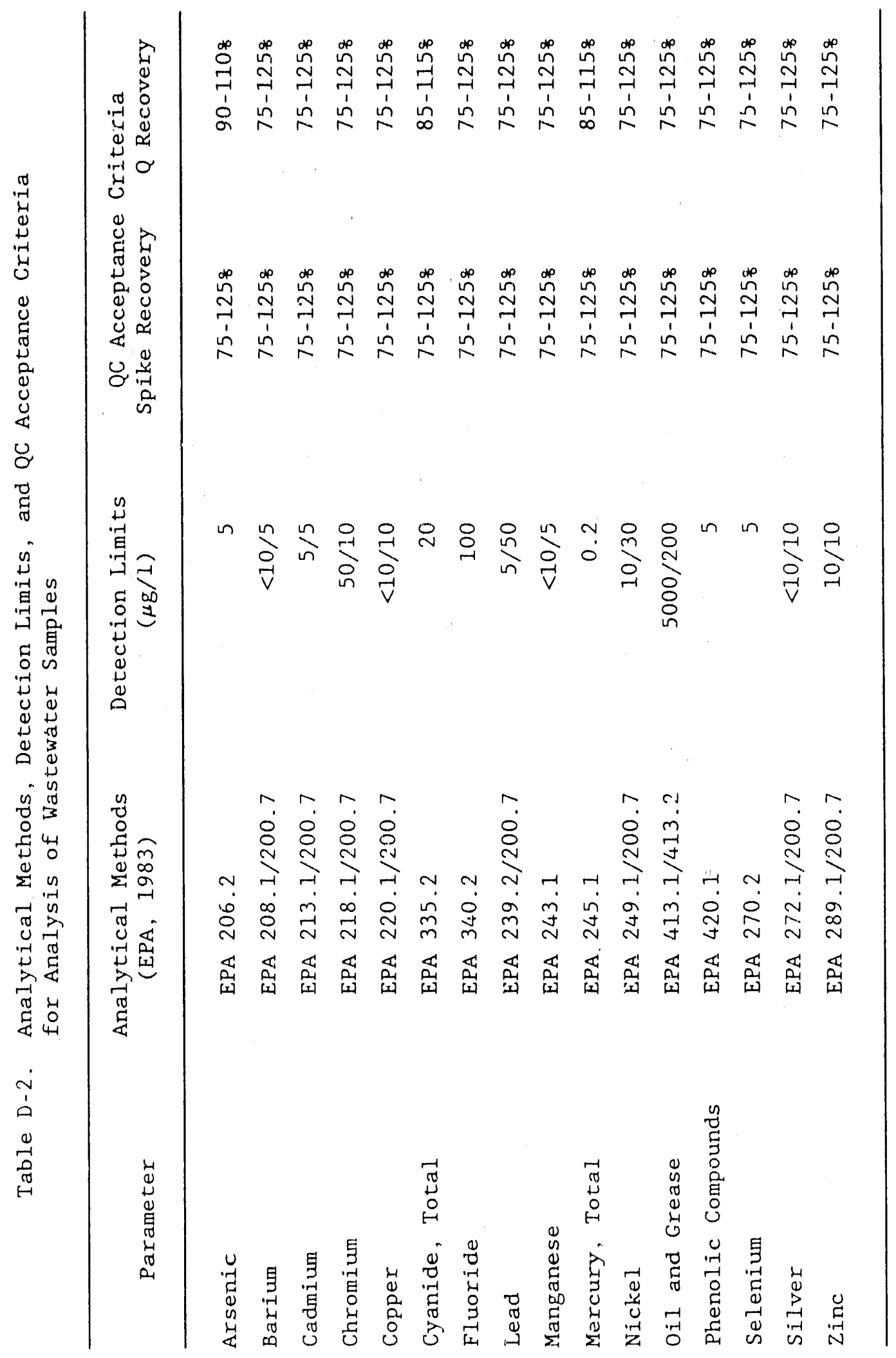




\section{REFERENCES}

U.S. Environmental Protection Agency (EPA), 1983. "Methods for Chemical Analysis of Water and Wastes," EPA-600/4-79-020, EPA, March 1983. 


\section{APPENDIX E \\ QUALITY ASSURANCE DATA}

E- $1 / 2$ 
Table E-1. List of Nonradioactive Environmental Samples Collected During CY89

\begin{tabular}{lrr}
\hline \multicolumn{1}{c}{ Type } & No. of Samples & No. of Analyses \\
\hline & 230 & 730 \\
Groundwater & 953 & 2400 \\
Wastewater & 467 & 467 \\
Oils/PCBs & 34 & 168 \\
Hazardous Wastes & 2 & 2 \\
Asbestus & 177 & 591 \\
Other & 1863 & 4408 \\
& & \\
\hline
\end{tabular}

Table E-2. List of Laboratories Used During CY89

Assaigai Analytical Laboratories, Inc.

Encotec

Enseco-Roc! y Mountain Analytical Labs

IT Analytical Services

Sandia National Laboratories Div. 3211

TMA Eberline 


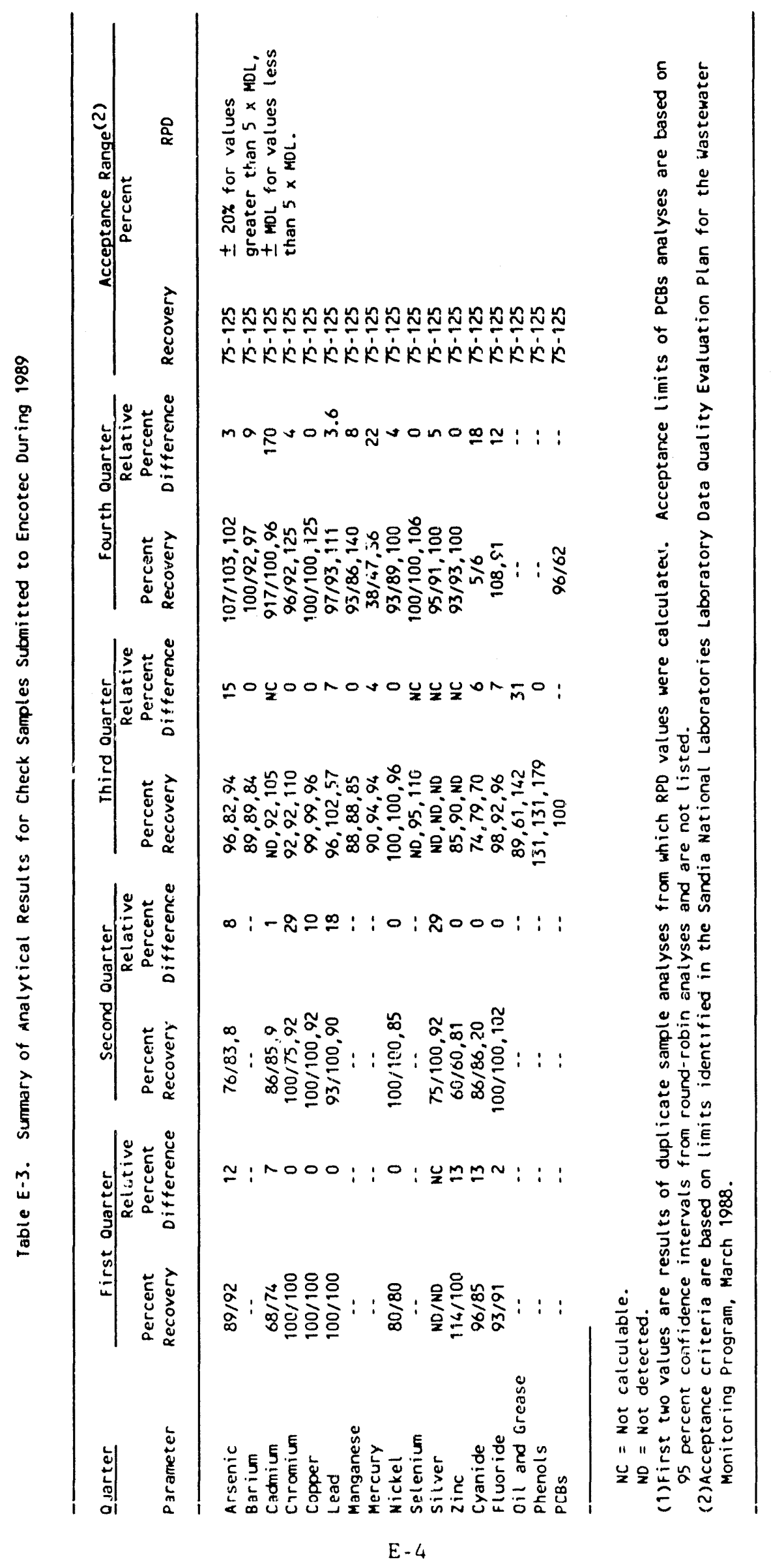




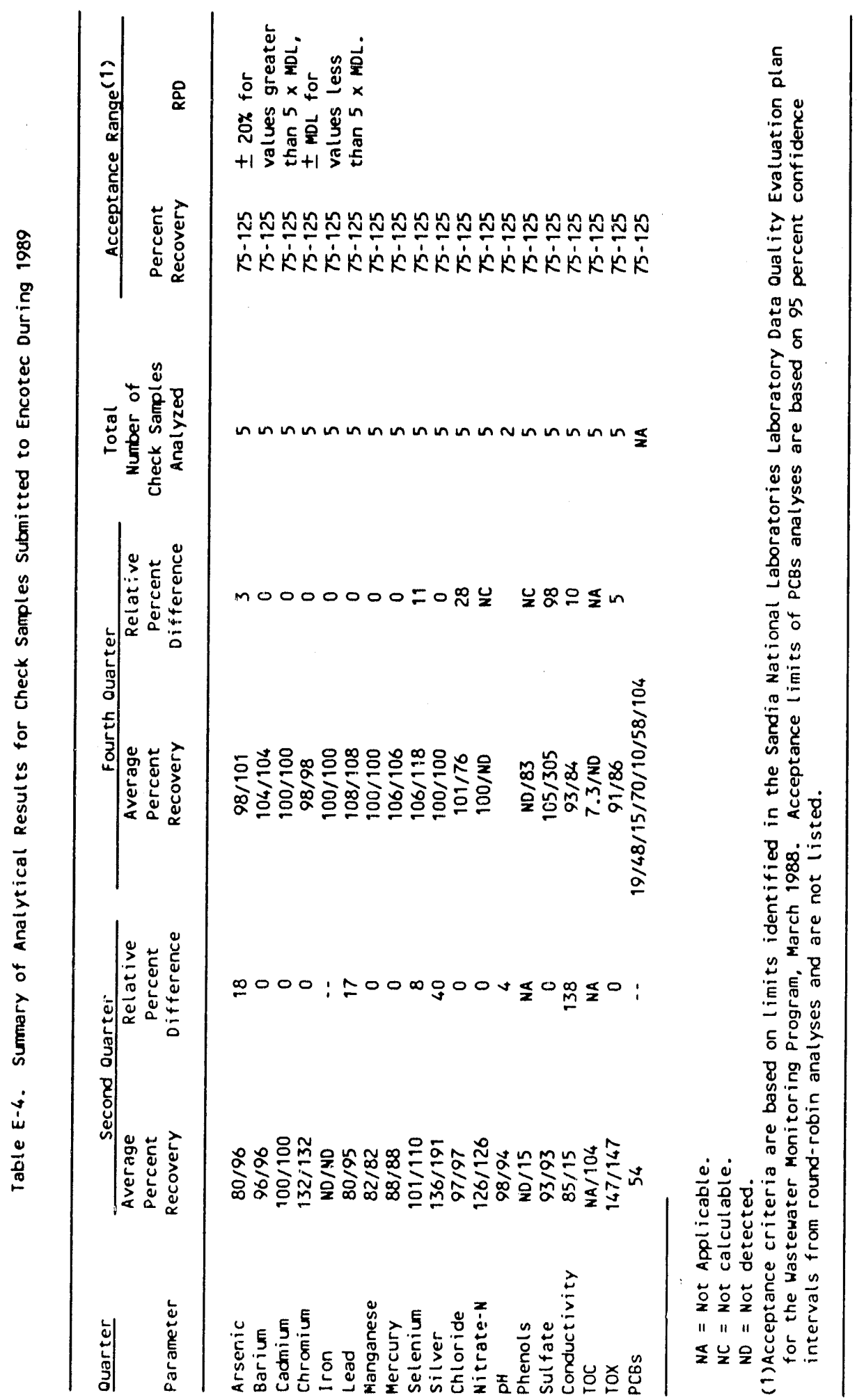


Table E-5. Department 3220 QA Plan Contents of 18 Quality Elements

1.0 ORGANIZATION

1.1 Authority and Responsibilities

1.2 Scope of Work

2.0 QUALITY ASSURANCE PROGRAM

2.1 Plans

2.2 Management Assessment

2.3 Familiarization, Training, and Qualification

3.0 DESIGN CONTROL AND ANALYSIS

3.1 Design Input

3.2 Design-Related Drawings

3.3 Analysis

3.4 Verification of Computer Programs Supporting Design Control and Analyses

4.0 CONTROL OF PROCUREMENT

4.1 Purchase Requests

4.2 Statements of Work

4.3 Procurement Source Evaluation

4.4 Bid Evaluation

5.0 INSTRUCTIONS, PROCEDURES, AND DRAWINGS

5.1 Procedure Content

5.2 Logbooks

5.3 Documentation of Photographs

5.4 Method of Logbook Entry

5.5 Corrections to Logbook Entries

5.6 Environment Safety \& Health

5.7 Security

5.8 Distribution

6.0 DOCUMENT CONTROL

6.1 Documents Issued By or For Division 3202

6.2 Documents Not Issued By or For Division 3202

6.3 SAND Reports

7.0 CONTROL OF PURCHASED ITEMS AND SERVICES

7.1 Review and Approval of Contractor Plans and Procedures

7.2 Performance Verification

7.3 Receiving Inspection

7.4 Deviation From Requirements 
Table E-5. Department 3220 QA Plan Contents of 18 Quality Elements (Continued)

8.0 IDENTIFICATION AND CONTROL OF MATERIALS AND SAMPLES

8.1 Sample Collection

8.2 Sample Identification

8.3 Sample Preservation and Handling

8.4 Chain of Custody

8.5 Sample Delivery

9.0 CONTROL OF PROCESSES

10.0 INSPECTIONS

10.1 General Criteria

10.2 Inspection Planning

11.0 TEST CONTROL

11.1 Test Procedures

11.2 Data Acquisition and Reduction

11.3 Test Results and Records

11.4 Quality Control. Samples

11.5 Data Verification

12.0 CONTROL OF MEASURING AND TEST EQUIPMENT

12.1 Frequency of Calibration

12.2 Calibration Labels

12.3 Calibration Certificates

12.4 Preventive Maintenance

12.5 Corrective Action

12.6 Exemptions

13.0 HANDLING, PACKAGING, STORAGE, AND SHIPPING

13.1 Special Equipment

13.2 Special Tools

13.3 Specific Instructions

14.0 INSPECTION, TEST, AND OPERATING STATUS

14.1 Methods of Indicating Status

14.2 Application and Removal of Status Indicators

15.0 CONTROL OF NONCONFORMANCES

16.0 CORRECTIVE ACTIONS 
1989 ENVIRONMENTAL MONITORING REPORT,

SANDIA NATIONAL LABORATORIES, ALBUQUERQUE

Table E-5. Department 3220 QA Plan Contents of 18 Quality Elements (Concluded)

17.0 RECORDS MANAGEMENT

17.1 Generation of QA Records

17.2 Acceptance of Records

17.3 Receipt of Records by the Records Manager

17.4 Records Identification

17.5 Storage

17.6 Critical Records

17.7 Preservation

17.8 Safekeeping

17.9 Corrections

17.10 Retrieval and Retention Times

18.0 AUDITS

18.1 Scope of Audits

18.2 Scheduling of Audits

18.3 Preparation of Audits

18.4 Reporting Audit Results

18.5 Response to Audits

18.6 Follow-Up Action 


\section{REFERENCES}

Sandia National Laboratories (SNL), Albuquerque, 1988. "Sandia National Laboratories Laboratory Data Quality Evaluation Plan for the Wastewater Monitoring Program," Sandia National Laboratories, Albuquerque, NM, March 1988. 


\section{APPENDIX F \\ ENVIRONMENTAL MONITORING DATA}

F- $1 / 2$ 
Table F-1. 1989 Vegetation Sample Analysis

\begin{tabular}{|c|c|c|c|c|c|c|c|c|}
\hline $\begin{array}{c}\text { Report } \\
\text { No. }\end{array}$ & Loc. Type & $\begin{array}{c}{ }^{3} \mathrm{H} \\
\mathrm{pC} 1 / \mathrm{m} 1\end{array}$ & $\begin{array}{c}{ }^{3} \mathrm{H} \\
S D E V\end{array}$ & $z \mathrm{H}_{2} \mathrm{O}$ & $\begin{array}{l}137 \mathrm{Cs} \\
\mathrm{pC} 1 / 8\end{array}$ & $\begin{array}{l}137^{\mathrm{Cs}} \\
\mathrm{SDEV}\end{array}$ & $\begin{array}{l}{ }^{40} \mathrm{~K} \\
\mathrm{pC} 1 / \mathrm{g}\end{array}$ & $\begin{array}{l}40 \mathrm{~K} \\
\text { SDEV }\end{array}$ \\
\hline 1 & s & $<0.45$ & - & 64.1 & $<0.03$ & - & 32.0 & 0.44 \\
\hline $2 \mathrm{NW}$ & $\mathrm{s}$ & $<0.45$ & - & 21.0 & $<0.03$ & 0.006 & 3.92 & 0.21 \\
\hline $2 \mathrm{SE}$ & $\mathrm{s}$ & $<0.45$ & - & 4.1 & 0.12 & 0.01 & 3.23 & 0.22 \\
\hline $2 \mathrm{NE}$ & $\mathrm{s}$ & 16.5 & 0.5 & 6.6 & 0.04 & 0.007 & 3.49 & 0.2 \\
\hline $2 \mathrm{SW}$ & $\mathrm{s}$ & $<0.45$ & - & 7.6 & 0.04 & 0.007 & 1.98 & 0.15 \\
\hline 3 & s & 0.5 & 0.5 & 5.9 & 0.18 & 0.01 & 3.98 & 0.2 \\
\hline 4 & P & $<0.45$ & - & 19.5 & $<0.02$ & - & 7.2 & 0.23 \\
\hline $5 \mathrm{~A}$ & $\mathrm{P}$ & $<0.45$ & - & 6.0 & 0.14 & 0.009 & 1.99 & 0.18 \\
\hline $5 \mathrm{~B}$ & $P$ & 1.0 & 0.5 & 6.3 & 0.13 & 0.01 & 1.56 & 0.19 \\
\hline $5 \mathrm{C}$ & P & 0.5 & 0.5 & 8.1 & 0.05 & 0.008 & 2.19 & 0.18 \\
\hline $6 \mathrm{~A}$ & s & $<0.45$ & - & 3.4 & 0.04 & 0.008 & 1.34 & 0.32 \\
\hline $6 \mathrm{~B}$ & s & $<0.45$ & - & 2.9 & 0.07 & 0.01 & 2.15 & 0.21 \\
\hline $6 \mathrm{C}$ & s & $<0.45$ & - & 5.4 & 0.06 & 0.009 & 2.5 & 0.22 \\
\hline $7 \mathrm{~A}$ & $\mathrm{~s}$ & $<0.45$ & - & 5.2 & 0.06 & 0.008 & 1.36 & 0.16 \\
\hline $7 \mathrm{~B}$ & $\mathrm{~S}$ & $<0.45$ & - & 4.9 & $<0.03$ & - & 1.15 & 0.17 \\
\hline $7 \mathrm{C}$ & $\mathrm{s}$ & $<0.45$ & - & 6.1 & 0.03 & 0.007 & 2.39 & 0.21 \\
\hline 8 & $\mathrm{C}$ & $<0.45$ & - & 54.8 & $<0.03$ & - & 7.24 & 0.27 \\
\hline 9 & $c$ & $<0.45$ & - & 49.7 & $<0.03$ & - & 10.3 & 0.29 \\
\hline 10 & C & $<0.45$ & - & 49.7 & $<0.03$ & - & 7.21 & 0.26 \\
\hline 11 & C & $<0.45$ & - & 48.5 & 0.02 & 0.006 & 9.34 & 0.27 \\
\hline $16 \mathrm{~A}$ & $P$ & $<0.45$ & - & 8.5 & $<0.03$ & - & 3.03 & 0.21 \\
\hline $16 \mathrm{~B}$ & $\mathrm{P}$ & $<0,45$ & - & 7.5 & $<0.03$ & - & 1.29 & 0.17 \\
\hline $16 \mathrm{C}$ & $\mathrm{P}$ & 1.1 & 0.5 & 5.2 & $<0.03$ & - & 1.37 & 0.18 \\
\hline 19 & $P$ & $<0.45$ & - & 18.3 & 0.09 & 0.008 & 6.01 & 0.22 \\
\hline 20 & $\mathrm{~S}$ & $<0.45$ & - & 3.2 & 0.11 & 0.009 & 3.92 & 0.19 \\
\hline 25 & C & $<0.45$ & - & 27.5 & $<0.02$ & - & 14.9 & 0.28 \\
\hline 33 & $\mathrm{~s}$ & 2.6 & 0.5 & 14.1 & $<0.03$ & - & 3.17 & 0.19 \\
\hline 34 & $\mathrm{~s}$ & $<0.45$ & - & 15.9 & 0.03 & 0.008 & 3.25 & 0.21 \\
\hline 35 & $\mathrm{~s}$ & $<0.45$ & - & 6.3 & 0.05 & 0.01 & 4.95 & 0.24 \\
\hline 45 & $\mathrm{~s}$ & $<0.45$ & - & 30.6 & $<0.03$ & - & 8.42 & 0.26 \\
\hline 49 & $\mathrm{~s}$ & $<0.45$ & - & 2.0 & 0.30 & 0.01 & 3.98 & 0.22 \\
\hline
\end{tabular}


Table F-2, 1989 Soll Sample Analysis

\begin{tabular}{|c|c|c|c|c|c|c|c|c|c|c|}
\hline $\begin{array}{l}\text { Report } \\
\text { No. }\end{array}$ & Loc. Type & $\begin{array}{l}\text { U-Tot } \\
\text { ug/s }\end{array}$ & $\begin{array}{l}\text { U-Tot } \\
\text { SDEV }\end{array}$ & $\begin{array}{c}{ }_{\mathrm{H}} \\
\mathrm{pCi} / \mathrm{ml}\end{array}$ & $\begin{array}{c}{ }_{\mathrm{H}} \mathrm{H} \\
\mathrm{SDEV}\end{array}$ & $x \mathrm{H}_{2} \mathrm{O}$ & $\begin{array}{l}137 \mathrm{Cs} \\
\mathrm{pC} 1 / \mathrm{s}\end{array}$ & $\begin{array}{l}137_{C s} \\
\text { SDEV }\end{array}$ & $\begin{array}{c}40 \mathrm{~K} \\
\mathrm{pC} 1 / \mathrm{s}\end{array}$ & $\begin{array}{l}{ }^{40} K \\
\text { SDEV }\end{array}$ \\
\hline 1 & $\mathrm{~s}$ & 2.6 & 0.2 & 10.3 & 1.0 & 1.3 & 0.43 & 0.02 & 17.7 & 0.39 \\
\hline $2 \mathrm{NW}$ & $\mathrm{S}$ & 2.9 & 0.2 & 8.1 & 1.0 & 0.01 & 0.35 & 0.01 & 15.6 & 0.29 \\
\hline $2 \mathrm{SE}$ & $\mathrm{s}$ & 2.0 & 0.2 & 4.7 & 1.0 & 0.06 & 0.7 & 0.02 & 16.1 & 0.29 \\
\hline $2 \mathrm{NE}$ & $\mathrm{s}$ & 2.1 & 0.2 & 6.7 & 1.0 & 0.04 & 0.42 & 0.01 & 16.0 & 0.3 \\
\hline $2 \mathrm{SW}$ & $\mathrm{s}$ & 2.0 & 0.2 & 7.0 & 1.0 & 0.02 & 0.57 & 0.02 & 16.5 & 0.3 \\
\hline 3 & $\mathrm{~s}$ & 2.7 & 0.2 & 11.2 & 1.0 & 0.44 & 0.44 & 0.01 & 19.2 & 0.32 \\
\hline 4 & $\mathrm{P}$ & 2.7 & 0.2 & 6.9 & 1.0 & 0.37 & 0.3 & 0.01 & 18.4 & 0.3 \\
\hline $5 A$ & $P$ & 2.5 & 0.2 & 8.1 & 1.0 & 0.29 & $<0.008$ & - & 0.29 & 0.04 \\
\hline $5 \mathrm{~B}$ & $\mathrm{P}$ & 2.6 & 0.2 & 6.3 & 1.0 & 0.27 & 0.57 & 0.02 & 16.3 & 0.3 \\
\hline $5 \mathrm{C}$ & $\mathrm{P}$ & 2.6 & 0.2 & 8.4 & 1.0 & 0.28 & 0.5 & 0.01 & 15.7 & 0.29 \\
\hline $6 A$ & $\mathrm{~s}$ & 2.7 & 0.2 & 4.4 & 1.0 & 0.17 & 0.49 & 0.01 & 16.9 & 0.3 \\
\hline $6 \mathrm{~B}$ & $\mathrm{~s}$ & 2.9 & 0.2 & 3.5 & 1.0 & 0.15 & 0.45 & 0.01 & 17.1 & 0.3 \\
\hline $6 \mathrm{C}$ & $\mathrm{s}$ & 2.9 & 0.2 & 3.4 & 1.0 & 0.12 & 0.43 & 0.01 & 17.1 & 0.3 \\
\hline $7 \mathrm{~A}$ & $\mathrm{~s}$ & 2.1 & 0.2 & 5.0 & 1.0 & 0.53 & 0.61 & 0.02 & 19.2 & 0.33 \\
\hline $7 B$ & s & 2.0 & 0.2 & 2.5 & 1.0 & 0.52 & 0.7 & 0.02 & 18.0 & 0.31 \\
\hline $7 \mathrm{C}$ & $\mathrm{s}$ & 2.2 & 0.2 & 1.8 & 1.0 & 0.48 & 0.59 & 0.01 & 18.5 & 0.31 \\
\hline 8 & $\mathrm{C}$ & 2.3 & 0.2 & 9.4 & 1.0 & 0.25 & $<0.02$ & - & 17.5 & 0.3 \\
\hline 9 & C & 2.6 & 0.2 & 7.6 & 1.0 & 3.8 & 0.3 & 0.01 & 14.8 & 0.3 \\
\hline 10 & c & 2.5 & 0.2 & 5.7 & 1.0 & 2.5 & 0.79 & 0.02 & 15.2 & 0.31 \\
\hline 11 & C & 2.5 & 0.2 & 8.7 & 1.0 & 0.5 & 0.08 & 0.007 & 17.7 & 0.3 \\
\hline $16 \mathrm{~A}$ & $\mathrm{P}$ & 2.6 & 0.2 & 6.4 & 1.0 & 0.53 & 0.11 & 0.008 & 26.0 & 0.35 \\
\hline $16 \mathrm{~B}$ & $\mathrm{P}$ & 2.6 & 0.2 & 8.6 & 1.0 & 0.5 & 0.11 & 0.01 & 25.2 & $0.3 E$ \\
\hline $16 \mathrm{C}$ & $\mathrm{P}$ & 2.6 & 0.2 & 6.8 & 1.0 & 0.56 & 0.1 & 0.009 & 24.7 & 0.34 \\
\hline 19 & $\mathrm{P}$ & 2.0 & 0.2 & 6.7 & 1.0 & 0.61 & 0.88 & 0.02 & 19.6 & 0.32 \\
\hline 20 & $\mathrm{~s}$ & 2.1 & 0.2 & 3.1 & 1.0 & 0.15 & 0.59 & 0.02 & 15.8 & 0.3 \\
\hline 25 & $c$ & 2.8 & 0.2 & 5.5 & 1.0 & 0.32 & 0.06 & 0.006 & 18.8 & 0.31 \\
\hline 33 & $\mathrm{~s}$ & 2.5 & 0.2 & 8.1 & 1.0 & 0.65 & 0.1 & 0.008 & 17.3 & 0.32 \\
\hline 34 & $\mathrm{~s}$ & 2.3 & 0.2 & 6.1 & 1.0 & 1.5 & 0.34 & 0.01 & 16.3 & 0.3 \\
\hline 35 & $\mathrm{~s}$ & 2.2 & 0.2 & 2.4 & 1.0 & 0.09 & 0.4 & 0.01 & 18.2 & 0.32 \\
\hline 45 & $\mathrm{~s}$ & 2.7 & 0.2 & 6.0 & 1.0 & 0.32 & 0.7 & 0.02 & 19.7 & 0.32 \\
\hline 49 & $\mathrm{~s}$ & 2.2 & 0.2 & 7.2 & 1.0 & 0.04 & 0.6 & 0.02 & 19.7 & 0.33 \\
\hline
\end{tabular}


Table F-3, 1989 Water Sample Analys1s - Surfaco Water

\begin{tabular}{|c|c|c|c|c|c|c|c|c|c|c|c|}
\hline $\begin{array}{c}\text { Sample } \\
\text { Type }\end{array}$ & & $\begin{array}{l}\text { Gross } \\
\text { Alpha } \\
\times 10^{-3} \\
\mathrm{pC} 1 / \mathrm{m} 1\end{array}$ & $\begin{array}{l}\text { Alpha } \\
\text { SDEV } \\
\times 10^{-3}\end{array}$ & $\begin{array}{l}\text { Gross } \\
\text { Beta } \\
\times 10^{-3} \\
\mathrm{pCl} 1 / \mathrm{ml}\end{array}$ & $\begin{array}{l}\text { Beta } \\
\text { SDEV } \\
\times 10^{-3}\end{array}$ & $\begin{array}{l}U \text {-Tot } \\
\text { Ug } / \mathrm{ml}\end{array}$ & $\begin{array}{l}\text { U-Tot } \\
\text { SDEV }\end{array}$ & $\begin{array}{c}{ }^{3} \mathrm{H} \\
\mathrm{p} C 1 / \mathrm{ml}\end{array}$ & $\begin{array}{c}3_{\mathrm{H}} \\
\text { SDEV }\end{array}$ & $\begin{array}{l}137 \mathrm{Cs} \\
\mathrm{pC} .1 / \mathrm{m} 1 \\
\times 10^{-3}\end{array}$ & $\begin{array}{c}137 \mathrm{CB} \\
\mathrm{SDEV} \\
\times \quad 10^{-3}\end{array}$ \\
\hline Number: & 8 & & & & & & & & & & \\
\hline $\mathrm{F}$ & & $<2.8$ & - & $<18.5$ & - & $<0.012$ & - & $<0.45$ & - & $<0.01$ & - \\
\hline $\mathrm{s}$ & & 1.5 & 0.9 & $<0,4$ & - & $<0,012$ & - & - & - & - & - \\
\hline$T$ & & $<2.8$ & - & $<18.5$ & - & $<0.012$ & - & $<0.45$ & - & $<0.01$ & - \\
\hline Numbor: & 11 & & & & & & & & & & \\
\hline F & & 5.3 & 3.2 & 19.9 & 17.4 & $<0.012$ & - & $<0.45$ & - & $<0.01$ & - \\
\hline $\mathrm{S}$ & & 1.9 & 1.1 & $<0.4$ & - & $<0.012$ & - & - & - & - & - \\
\hline $\mathrm{T}$ & & $<2.8$ & - & $<18.5$ & - & $<0.012$ & - & $<0.45$ & - & $<0.01$ & . \\
\hline Number: & $33 \mathrm{~A}$ & & & & & & & & & & \\
\hline F & & $<2.8$ & - & $<18.5$ & - & $<0.012$ & - & $<0.45$ & - & $<0.01$ & - \\
\hline $\mathrm{S}$ & & $<0.2$ & - & $<0.4$ & - & $<0.012$ & - & - & - & - & - \\
\hline $\mathrm{T}$ & & $<2.8$ & - & $<18.5$ & - & $<0.012$ & - & $<0.45$ & - & $<0.01$ & - \\
\hline Number: & $33 B$ & & & & & & & & & & \\
\hline $\mathrm{F}$ & & $<2.8$ & - & $<18.5$ & - & $<0.012$ & - & $<0.45$ & - & $<0.01$ & - \\
\hline S & & $<0.03$ & - & $<0.4$ & - & $<0.012$ & - & - & - & - & - \\
\hline $\mathrm{T}$ & & $<2.8$ & - & $<18.5$ & - & $<0.012$ & - & $<0.45$ & - & $<0.01$ & - \\
\hline Number: & $33 \mathrm{C}$ & & & & & & & & & & \\
\hline F & & $<2.8$ & - & 22.6 & 17.4 & $<0.012$ & - & $<0.45$ & - & $<0.01$ & - \\
\hline$s$ & & $<0.03$ & - & $<0.4$ & - & $<0.012$ & - & - & - & - & - \\
\hline $\mathrm{T}$ & & $<2.8$ & - & 32.8 & .17 .5 & $<0.012$ & - & $<0,45$ & - & $<0.01$ & - \\
\hline
\end{tabular}


Table F-4. 1980 Water Sample Analys 1 s - Well Water

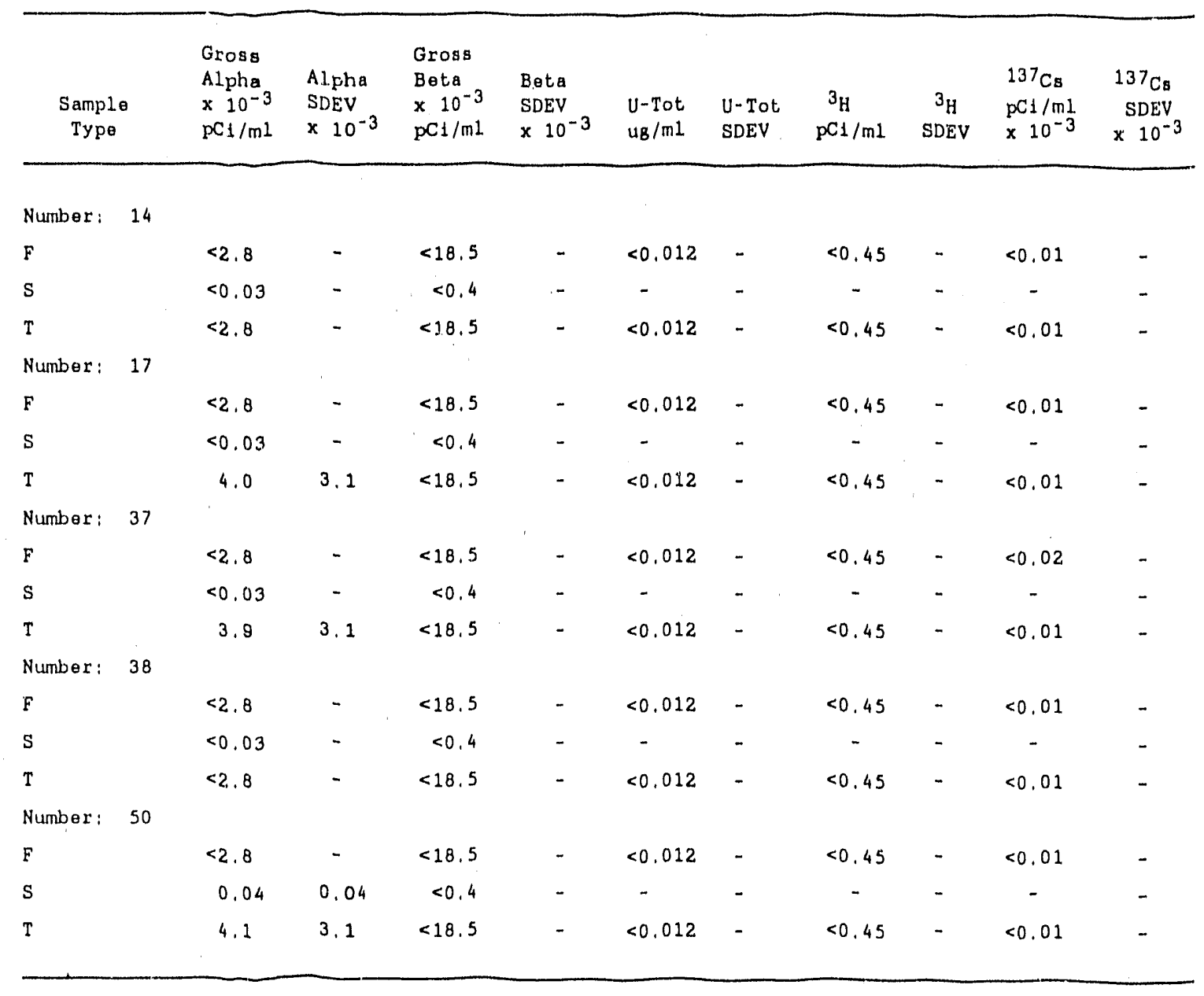


Table F-5. 1989 Thermoluminesoent Dosimeter (TLD) Surmary Radiation Exposure Data

\begin{tabular}{|c|c|c|c|c|c|c|c|c|c|}
\hline $\begin{array}{l}\text { Report } \\
\text { No }\end{array}$ & $\begin{array}{l}\text { Ist } \\
\text { Field }\end{array}$ & $\begin{array}{l}\text { Qtr. } \\
\text { Exposura }\end{array}$ & $\begin{array}{l}\text { 2nd } \\
\text { Field }\end{array}$ & $\begin{array}{l}\text { Qtr. } \\
\text { Exposure }\end{array}$ & $\begin{array}{l}3 \text { rd } \\
\text { Fleld }\end{array}$ & $\begin{array}{l}\text { Qtr. } \\
\text { Exposure }\end{array}$ & $\begin{array}{l}4 \text { th } \\
\text { Fiold }\end{array}$ & $\begin{array}{l}\text { Qtr } \\
\text { Exposure }\end{array}$ & Dose \\
\hline & & & & & & & & & $\operatorname{miR} / 365 d$ (ercor) \\
\hline
\end{tabular}

Location Type: C

$\begin{array}{rrrrrrrrrr}10 & 84 & 21.5 & 78 & 21.7 & 104 & 31.5 & 94 & 27.2 & 103(5) \\ 11 & 84 & 20.0 & 78 & 13.7 & 104 & 22.6 & 94 & 21.7 & 79(8) \\ 21 & 84 & 21.4 & 78 & 19.2 & 104 & 26.8 & 94 & 21.5 & 90(17) \\ 22 & 84 & 19.5 & 78 & 17.6 & 104 & 22.9 & 94 & 22.0 & 83(6) \\ 23 & 84 & 19.5 & 78 & 16.3 & 104 & 24.7 & 94 & \mathrm{NA}^{\mathrm{b}} & 83(8) \\ 24 & 84 & 22.5 & 78 & 18.9 & 104 & 26.8 & 94 & 26.1 & 96(9) \\ 25 & 84 & 25.5 & 78 & 20.8 & 104 & 32.6 & 94 & 29.0 & 109(11) \\ 26 & 84 & 26.7 & 78 & 22.2 & 104 & 31.1 & 94 & 25.0 & 106(15) \\ 27 & 84 & 22.8 & 78 & 15.9 & 104 & 26.9 & 94 & 23.8 & 91(11) \\ 28 & 84 & 22.5 & 78 & 16.8 & 104 & 26.9 & 94 & 25.0 & 92(9) \\ 29 & 84 & 20.1 & 78 & 17.6 & 104 & 24.3 & 94 & 22.8 & 86(9) \\ 30 & 84 & 24.2 & 78 & 17.7 & 104 & 28.6 & 94 & 27.3 & 99(10)\end{array}$

\section{Location Type: P}

$\begin{array}{rrrrrrrrrr}4 & 84 & 23.1 & 78 & 19.6 & 104 & 29.3 & 92 & 23.1 & 97(5) \\ 5 & 84 & 22.2 & 78 & 16.5 & 104 & 24.3 & 92 & 20.7 & 85(10) \\ 16 & 84 & 24.1 & 78 & 21.9 & 104 & 34.0 & 92 & 28.8 & 111(8) \\ 18 & 84 & 23.9 & 78 & 17.4 & 104 & 27.3 & 92 & 20.8 & 91(9) \\ 19 & 84 & 25.7 & 78 & 20.7 & 104 & 30.3 & 92 & 24.1 & 104(6) \\ 39 & 84 & 20.8 & 78 & 18.4 & 104 & 25.0 & 92 & 21.2 & 87(8) \\ 40 & 84 & 22.9 & 78 & 37.2 & 104 & 25.3 & 92 & 22.9 & 110(12)\end{array}$

\begin{tabular}{|c|c|c|c|c|c|c|c|c|c|}
\hline 1 & 84 & 21.4 & 78 & 17.8 & 104 & 29.2 & 92 & 31.7 & $102(12)$ \\
\hline 2 & 84 & 24.9 & 78 & 20.4 & 104 & $\mathrm{NA}^{\mathrm{b}}$. & 92 & 25.7 & $102(6)$ \\
\hline 3 & 84 & $N A^{b}$ & 78 & 1.7 .9 & 104 & 28.5 & 92 & -25.3 & $96(12)$ \\
\hline 6 & 84 & 24.2 & 78 & 18.4 & 104 & 28.6 & 92 & 23.5 & $96(8)$ \\
\hline 7 & 84 & 31.2 & 78 & 23.8 & 104 & 34.1 & 92 & 29.6 & 121 (9) \\
\hline 20 & 84 & 21.9 & 78 & 20.3 & 104 & 29.6 & 92 & 25.9 & $100(9)$ \\
\hline 31 & 84 & 23.2 & 78 & 15.4 & 104 & 29.1 & 92 & 24.6 & $94(12)$ \\
\hline 41 & 84 & 55.9 & 78 & 82.1 & 104 & 65.5 & 92 & 68.0 & $277(31)$ \\
\hline 42 & 84 & 25.6 & 78 & 21.7 & 104 & 27.7 & 92 & 24.5 & 101 (9) \\
\hline 43 & 84 & 21.5 & 78 & 18.5 & 104 & 25.9 & 92 & 22.4 & $90(7)$ \\
\hline 46 & 84 & 24,8 & 78 & 20.0 & 104 & 25.3 & 92 & 28.6 & $111(10)$ \\
\hline 47 & 84 & 25.0 & $7 B$ & 23.3 & 104 & 34.1 & 92 & 27.4 & 112 (11) \\
\hline 48 & 84 & 25.1 & 78 & 20.0 & 104 & 31.0 & 92 & 27.1 & $105(9)$ \\
\hline
\end{tabular}

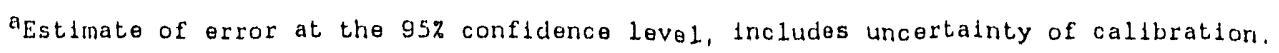

$b_{N A}=$ data was not avallable. 
Table F-6. 1989 Calculated Effluent Release Data

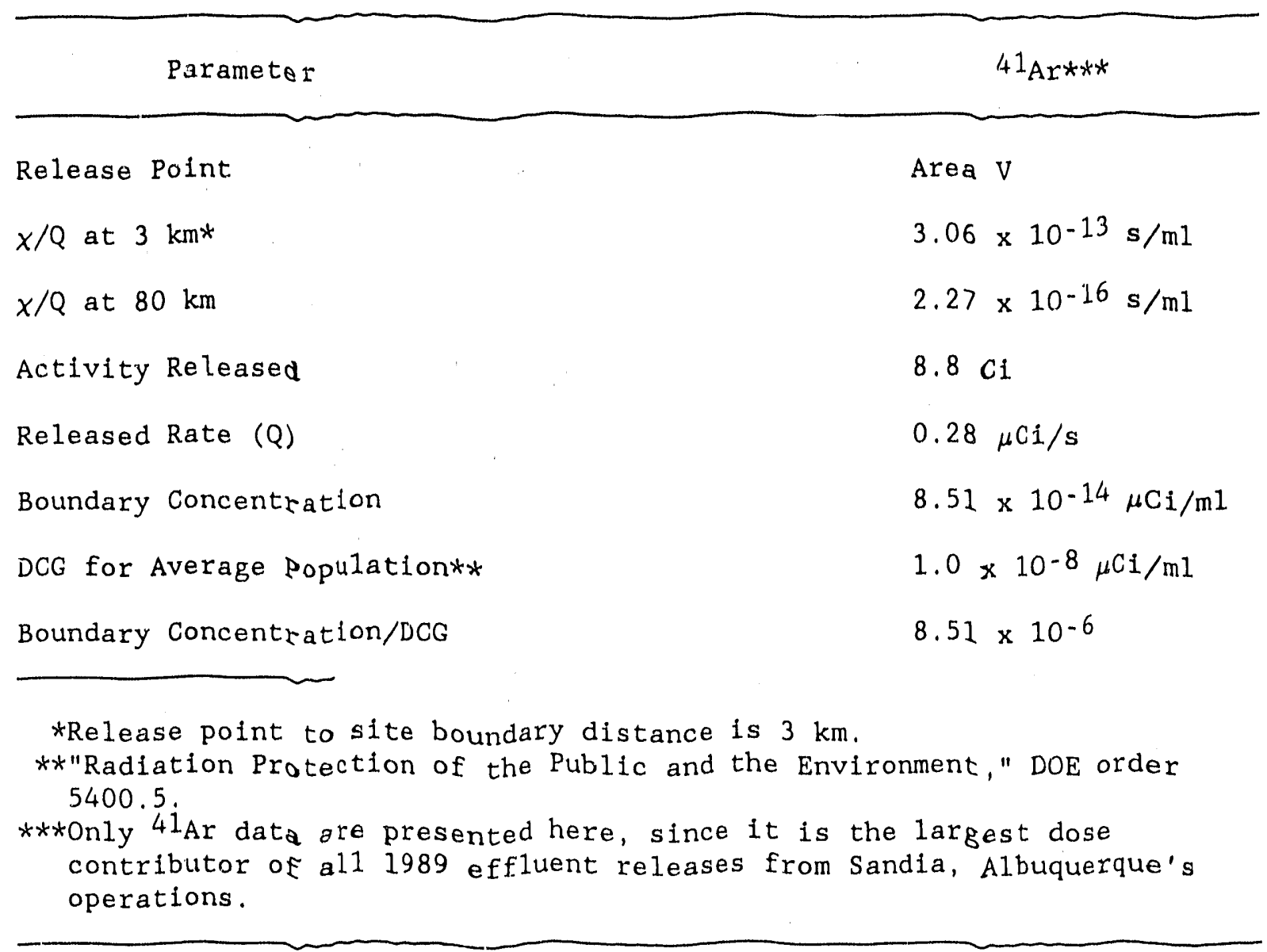


Table F-7a. Background Concentrations of Groundwater Contamination Indicator Parameters for $\mathrm{BW}-3$

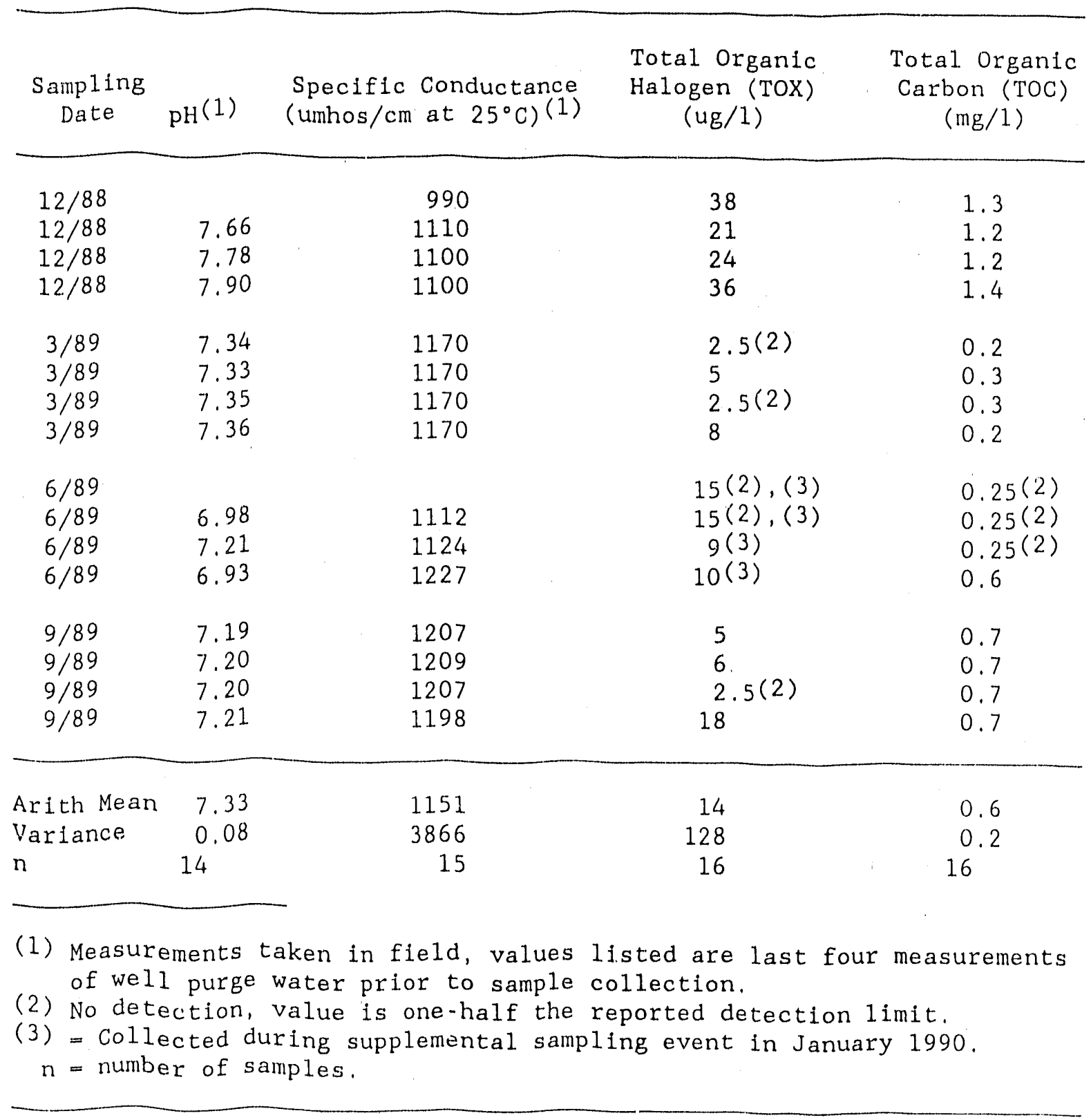


Table F-7b. Background Concentrations of Groundwater Contamination Indicator Parameters for MW-1A

\begin{tabular}{|c|c|c|c|c|}
\hline $\begin{array}{l}\text { Sampling } \\
\text { Date }\end{array}$ & $\mathrm{pH}(1)$ & $\begin{array}{l}\text { Specific Conductance } \\
\text { (umhos } / \mathrm{cm} \text { at } 25^{\circ} \mathrm{C} \text { ) (1) }\end{array}$ & $\begin{array}{c}\text { Total Organic } \\
\text { Halogen (TOX) } \\
\text { (ug/l) }\end{array}$ & $\begin{array}{c}\text { Total Organic } \\
\text { Carbon (TOC) } \\
(\mathrm{mg} / 1)\end{array}$ \\
\hline $\begin{array}{l}12 / 88 \\
12 / 88 \\
12 / 88 \\
12 / 88\end{array}$ & $\begin{array}{l}7.41 \\
7.37 \\
7.36 \\
7.36\end{array}$ & $\begin{array}{l}790 \\
800 \\
810 \\
820\end{array}$ & $\begin{array}{l}14 \\
20 \\
26 \\
19\end{array}$ & $\begin{array}{l}0.9 \\
1.0 \\
1.0 \\
1.2\end{array}$ \\
\hline $\begin{array}{l}3 / 89 \\
3 / 89 \\
3 / 89 \\
3 / 89\end{array}$ & $\begin{array}{l}7.35 \\
7.29 \\
7.28 \\
7.29\end{array}$ & $\begin{array}{l}1000 \\
1000 \\
1000 \\
1000\end{array}$ & $\begin{array}{l}2.5(2) \\
3(1) \\
5.0 \\
8\end{array}$ & $\begin{array}{l}0.5 \\
0.4 \\
0.3 \\
0.3\end{array}$ \\
\hline $\begin{array}{l}6 / 89 \\
6 / 89 \\
6 / 89 \\
6 / 89\end{array}$ & $\begin{array}{l}7.05 \\
7.05 \\
7.05 \\
7.06\end{array}$ & $\begin{array}{l}1019 \\
1009 \\
1011 \\
1002\end{array}$ & $\begin{array}{l}15(2),(3) \\
15(2),(3) \\
8.0(3) \\
15(2),(3)\end{array}$ & $\begin{array}{l}0.25(2) \\
0.25(2) \\
0.25(2) \\
0.3(2)\end{array}$ \\
\hline $\begin{array}{l}9 / 89 \\
9 / 89 \\
9 / 89 \\
9 / 89\end{array}$ & $\begin{array}{l}7.06 \\
7.05 \\
7.05 \\
7.05\end{array}$ & $\begin{array}{l}1041 \\
1038 \\
1038 \\
1039\end{array}$ & $\begin{array}{l}2.5(2) \\
2.5(2) \\
2.5(2) \\
2.5(2)\end{array}$ & $\begin{array}{l}0.3 \\
0.3 \\
0.3 \\
0.3\end{array}$ \\
\hline $\begin{array}{l}\text { Arith Mean } \\
\text { Variance } \\
n\end{array}$ & $\begin{array}{l}7.20 \\
0.02 \\
16\end{array}$ & $\begin{array}{r}0 \\
9201 \\
16\end{array}$ & $\begin{array}{l}10 \\
60 \\
16\end{array}$ & $\begin{array}{l}0.5 \\
0.1 \\
16\end{array}$ \\
\hline \multicolumn{5}{|c|}{$\begin{array}{l}\text { (1) Measurements taken in field, values listed are last four measurements } \\
\text { well purge water prior to sample collection. } \\
\text { (2) No detection, value is one-hatf the reported detection limit. } \\
\text { (3) }=\text { Collected during supplemental sampling event in January } 1990 . \\
n=\text { number of samples. }\end{array}$} \\
\hline
\end{tabular}


Table F-7c. Background Concentrations of Groundwater Contamination Indicator Parameters for $\mathrm{MW}-2 \mathrm{~A}$

\begin{tabular}{|c|c|c|c|c|}
\hline $\begin{array}{l}\text { Sampling } \\
\text { Date }\end{array}$ & $\mathrm{pH}(1)$ & $\begin{array}{l}\text { Specific Conductance } \\
\left.\text { (umhos } / \mathrm{cm} \text { at } 25^{\circ} \mathrm{C}\right)(1)\end{array}$ & $\begin{array}{c}\text { Total Organic } \\
\text { Halogen (TOX) } \\
\text { (ug/1) }\end{array}$ & $\begin{array}{c}\text { Total Organic } \\
\text { Carbon (TOC) } \\
(\mathrm{mg} / \mathrm{l})\end{array}$ \\
\hline $12 / 88$ & 7.29 & 970 & 106 & 0.2 \\
\hline $12 / 88$ & 7.49 & 970 & 103 & 0.2 \\
\hline $12 / 88$ & 7.34 & 970 & 95 & 0.3 \\
\hline $12 / 88$ & 7.56 & 980 & 110 & 1.4 \\
\hline $3 / 89$ & 7.53 & 1040 & 12 & $0.3(2)$ \\
\hline $3 / 89$ & 7.46 & 1040 & 12 & 0.1 \\
\hline $3 / 89$ & 7.44 & 1040 & 7 & 0.1 \\
\hline $3 / 89$ & 7.42 & 1040 & 14 & $0.3(2)$ \\
\hline $6 / 89$ & 7.56 & 1049 & $40(3)$ & $0.25(2)$ \\
\hline $6 / 89$ & 7.41 & 1045 & $27(3)$ & $0.25(2)$ \\
\hline $6 / 89$ & 7.32 & 1027 & $30(3)$ & $0.25(2)$ \\
\hline $6 / 89$ & 7.41 & 1023 & $50(3)$ & 0.5 \\
\hline $9 / 89$ & 7.19 & 1027 & 19 & $0.3(2)$ \\
\hline $9 / 89$ & 7.19 & 1027 & 13 & $0.3(2)$ \\
\hline $9 / 89$ & 7.18 & 1027 & 11 & $0.3(2)$ \\
\hline $9 / 89$ & 7.18 & 1027 & 18 & 0.6 \\
\hline Arith Mean & 7.37 & 1019 & 42 & 0.3 \\
\hline Variance & 0.02 & 827 & 1493 & 0.1 \\
\hline $\mathrm{n}$ & 16 & 16 & 16 & 16 \\
\hline \multicolumn{5}{|c|}{$\begin{array}{l}\text { (1) Measurements taken in field, values listed are last four measurements of } \\
\text { well purge water prior to sample collection. } \\
\text { (2) No detection, value is one-half the reported detection limit. } \\
\text { (3) }=\text { Collected during supplemental sampling event in January } 1990 . \\
n=\text { number of samples. }\end{array}$} \\
\hline
\end{tabular}


Table F-7d. Background Concentrations of Groundwater Containination Indicator Parameters for $\mathrm{MW}-3 \mathrm{~A}$

\begin{tabular}{|c|c|c|c|c|}
\hline $\begin{array}{l}\text { Sampling } \\
\text { Date }\end{array}$ & $\mathrm{pH}(1)$ & $\begin{array}{l}\text { Specific Conductance } \\
\left(\text { umhos } / \mathrm{cm} \text { at } 25^{\circ} \mathrm{C}\right)(1)\end{array}$ & $\begin{array}{c}\text { Total Organic } \\
\text { Halogen (ToX) } \\
(\mathrm{ug} / 1)\end{array}$ & $\begin{array}{c}\text { Total Organic } \\
\text { Carbon (TDC) } \\
(\mathrm{mg} / 1)\end{array}$ \\
\hline $12 / 88$ & 7.78 & 990 & 32 & 0.6 \\
\hline $12 / 88$ & 7.80 & 990 & 34 & 0.5 \\
\hline $12 / 88$ & 7.71 & 990 & 32 & 0.5 \\
\hline $12 / 88$ & 7.71 & 920 & 19 & 0.6 \\
\hline $3 / 89$ & 7.79 & 1000 & $2.5(2)$ & 0.4 \\
\hline $3 / 89$ & 7.79 & 1000 & 5 & 0.2 \\
\hline $3 / 89$ & 7.81 & 1000 & 7.0 & 0.4 \\
\hline $3 / 89$ & 7.8 & 1000 & $3(2)$ & 0.3 \\
\hline $6 / 89$ & 7.27 & 1013 & $8(3)$ & $0.25(2)$ \\
\hline $6 / 89$ & 7.25 & 1008 & $6(3)$ & 0.80 \\
\hline $6 / 89$ & 7.23 & 1008 & $5(3)$ & 0.80 \\
\hline $6 / 89$ & 7.24 & 1008 & $5(3)$ & 0.8 \\
\hline $9 / 89$ & 7.16 & 1002 & 55 & $0.3(2)$ \\
\hline $9 / 89$ & 7.16 & 1002 & 58 & $0.3(2)$ \\
\hline $9 / 89$ & 7.17 & 1002 & 58 & $0.3(2)$ \\
\hline $9 / 89$ & 7.16 & 1001 & 58 & $0.4(2)$ \\
\hline Arith Mean & 7.49 & 996 & 24 & 0.5 \\
\hline Variance & 0.09 & 453 & 504 & 0.05 \\
\hline $\mathrm{n}$ & 16 & 16 & 16 & 16 \\
\hline \multicolumn{5}{|c|}{$\begin{array}{l}\text { (1) Measurements taken in field, values listed are last four measurements o } \\
\text { well purge water prior to sample collection. } \\
\text { (2) No detection, value is one-half the reported detection limit. } \\
\text { (3)= Collected during supplemental sampling event in January } 1990 . \\
n=\text { number of samples. }\end{array}$} \\
\hline
\end{tabular}


Table F-8a. Background Concentrations of Groundwater Quality Indicator Parameters for $\mathrm{BW}-3$

\begin{tabular}{|c|c|c|c|c|c|}
\hline \multirow[b]{2}{*}{ Constituent } & \multirow[b]{2}{*}{ Units } & \multicolumn{4}{|c|}{ Sampling Date } \\
\hline & & $12 / 88$ & $3 / 89$ & $6 / 89$ & $9 / 89$ \\
\hline Chloride & $(\mathrm{mg} / 1)$ & 116 & 114 & 123 & 129 \\
\hline \multirow{2}{*}{$\begin{array}{l}\text { Iron - } t \\
\text { Iron - } d\end{array}$} & $(\mathrm{mg} / 1)$ & 0.39 & 0.36 & 0.5 & 0.4 \\
\hline & $(\mathrm{mg} / 1)$ & $<0.012<0.05$ & $\mathrm{ND}<0.05$ & $\mathrm{ND}<0.1$ & $\mathrm{ND}<0.1$ \\
\hline Manganese - $t$ & $(\mathrm{mg} / 1)$ & 0.058 & 0.028 & 0.02 & 0.03 \\
\hline Manganese - d & $(\mathrm{mg} / 1)$ & 0.063 & 0.018 & 0.02 & 0.03 \\
\hline Phenols & $(\mathrm{mg} / 1)$ & $\mathrm{ND}<0.01$ & $\mathrm{ND}<0.01$ & 0.11 & $\mathrm{ND}<0.01$ \\
\hline \multirow{2}{*}{$\begin{array}{l}\text { Sodium }-t \\
\text { Sodium }-\mathrm{d}\end{array}$} & $(\mathrm{mg} / 1)$ & 141 & 138 & 113 & 128 \\
\hline & $(\mathrm{mg} / 1)$ & 144 & 142 & 112 & 137 \\
\hline Sulfate & $(\mathrm{mg} / 1)$ & 111 & 106 & 83 & 102 \\
\hline \multirow{2}{*}{\multicolumn{6}{|c|}{$\begin{aligned} t & =\text { Total metal concentration. } \\
\mathrm{d} & =\text { Dissolved metal concentration. } \\
\mathrm{ND} & =\text { Not detected at the method reporting limit stated in the table above }\end{aligned}$}} \\
\hline & & & & & table above. \\
\hline
\end{tabular}


1989 ENVIRONMENTAL MONITORING REPORT,

SANDIA NATIONAL LABORATORIES, ALBUQUERQUE

Table F-8b. Background Concentrations of Groundwater Quality

Indicator Parameters for MW-1A

\begin{tabular}{|c|c|c|c|c|c|}
\hline \multirow[b]{2}{*}{ Constituent } & \multirow[b]{2}{*}{ Units } & \multicolumn{4}{|c|}{ Sampling Date } \\
\hline & & $12 / 88$ & $3 / 89$ & $6 / 89$ & $9 / 89$ \\
\hline Chloride & $(\mathrm{mg} / 1)$ & 105 & 100 & 104 & 103 \\
\hline Iron - $t$ & $(\mathrm{mg} / 1)$ & 0.17 & 0.12 & 0.6 & $N D<0.1$ \\
\hline Iron - d & $(\mathrm{mg} / 1)$ & $N D<0.05$ & $N D<0.05$ & $N D<0.1$ & $N D<0.1$ \\
\hline Manganese - $t$ & $(\mathrm{mg} / 1)$ & 0.091 & 0.062 & 0.09 & 0.02 \\
\hline Manganese - d & $(\mathrm{mg} / 1)$ & 0.0469 & 0.063 & 0.04 & 0.01 \\
\hline Phenols & $(m g / 1)$ & 0.01 & 0.03 & $\mathrm{ND}<0.01$ & $\mathrm{ND}<0.01$ \\
\hline Sodium - $t$ & $(\mathrm{mg} / 1)$ & 145 & 72 & 74 & 74 \\
\hline Sodium - d & $(\mathrm{mg} / 1)$ & 75 & 73 & 74 & 80 \\
\hline Sulfate & $(\mathrm{mg} / 1)$ & 67 & 58 & 62 & 61 \\
\hline \multicolumn{6}{|c|}{$\begin{aligned} t & =\text { Total metal concentration. } \\
d & =\text { Dissolved metal concentration. } \\
N D & =\text { Not detected at the method repor }\end{aligned}$} \\
\hline
\end{tabular}


Table F-8c. Background Concentrations of Groundwater Quality Indicator Parameters for MW-2A

\begin{tabular}{|c|c|c|c|c|c|}
\hline \multirow[b]{2}{*}{ Constituent } & \multirow[b]{2}{*}{ Units } & \multicolumn{4}{|c|}{ Sampling Date } \\
\hline & & $12 / 88$ & $3 / 89$ & $6 / 89$ & $9 / 89$ \\
\hline Chloride & $(\mathrm{mg} / 1)$ & 99 & 99 & 99 & 104 \\
\hline Iron - $t$ & $(\mathrm{mg} / \mathrm{l})$ & 0.96 & 0.16 & 0.3 & $N D<0.1$ \\
\hline Iron - d & $(\mathrm{mg} / 1)$ & $\mathrm{ND}<0.05$ & $N D<0.05$ & $\mathrm{ND}<0.1$ & $\mathrm{ND}<0.1$ \\
\hline Manganese - $t$ & $(\mathrm{mg} / 1)$ & 0.066 & 0.018 & 0.111 & $\mathrm{ND}<0.01$ \\
\hline Manganese - d & $(\mathrm{mg} / 1)$ & 0.069 & 0.006 & $N D<0.01$ & 0.01 \\
\hline Phenols & $(\mathrm{mg} / 1)$ & $N D<0.01$ & $\mathrm{ND}<0.01$ & $N D<0.01$ & $N D<0.01$ \\
\hline Sodium - $t$ & $(\mathrm{mg} / 1)$ & 78 & 72 & 75 & 75 \\
\hline Sodium - d & $(\mathrm{mg} / 1)$ & 80 & 74 & 74 & 82 \\
\hline Sulfate & $(\mathrm{mg} / 1)$ & 65 & 59 & 59 & 61 \\
\hline \multicolumn{6}{|c|}{$\begin{aligned} t & =\text { Total metal concentration } \\
d & =\text { Dissolved metal concentration. }\end{aligned}$} \\
\hline
\end{tabular}


1989 ENVIRONMENTAL MONITORING REPORT,

Table F-8d. Background Concentrations of Groundwater Quality Indicator Parameters for MW-3A

\begin{tabular}{|c|c|c|c|c|c|}
\hline \multirow[b]{2}{*}{ Constituent } & \multirow[b]{2}{*}{ Units } & \multicolumn{4}{|c|}{ Sampling Date } \\
\hline & & $12 / 88$ & $3 / 89$ & $6 / 89$ & $9 / 89$ \\
\hline Chloride & $(\mathrm{mg} / 1)$ & 97 & 94 & 97 & 99 \\
\hline Iron - $t$ & $(\mathrm{mg} / 1)$ & $N D<0.05$ & 0.06 & $\mathrm{ND}<0.1$ & $N D<0.1$ \\
\hline Iron - d & $(\mathrm{mg} / 1)$ & $N D<0.05$ & ND<0.05 & $\mathrm{ND}<0.1$ & $\mathrm{ND}<0.1$ \\
\hline Manganese - $t$ & (mg/1) & 0.022 & 0.018 & $N D<0.01$ & $\mathrm{ND}<0.01$ \\
\hline Manganese - d & $(\mathrm{mg} / 1)$ & 0.017 & 0.014 & $\mathrm{ND}<0.01$ & $N D<0.01$ \\
\hline Phenols & $(\mathrm{mg} / 1)$ & $\mathrm{ND}<0.01$ & $N D<0.01$ & $N D<0.01$ & 0.27 \\
\hline Sodium - $t$ & $(\mathrm{mg} / 1)$ & 101 & 92 & 86 & 79 \\
\hline Sodium - d & $(\mathrm{mg} / 1)$ & 106 & 87 & 79 & 81 \\
\hline Sulfate & $(\mathrm{mg} / 1)$ & 68 & 63 & 62 & 63 \\
\hline \multicolumn{6}{|c|}{$\begin{aligned} t & =\text { Total metal concentration. } \\
\mathrm{d} & =\text { Dissolved metal concentration. } \\
N D & =\text { Not detected at the method repor }\end{aligned}$} \\
\hline
\end{tabular}




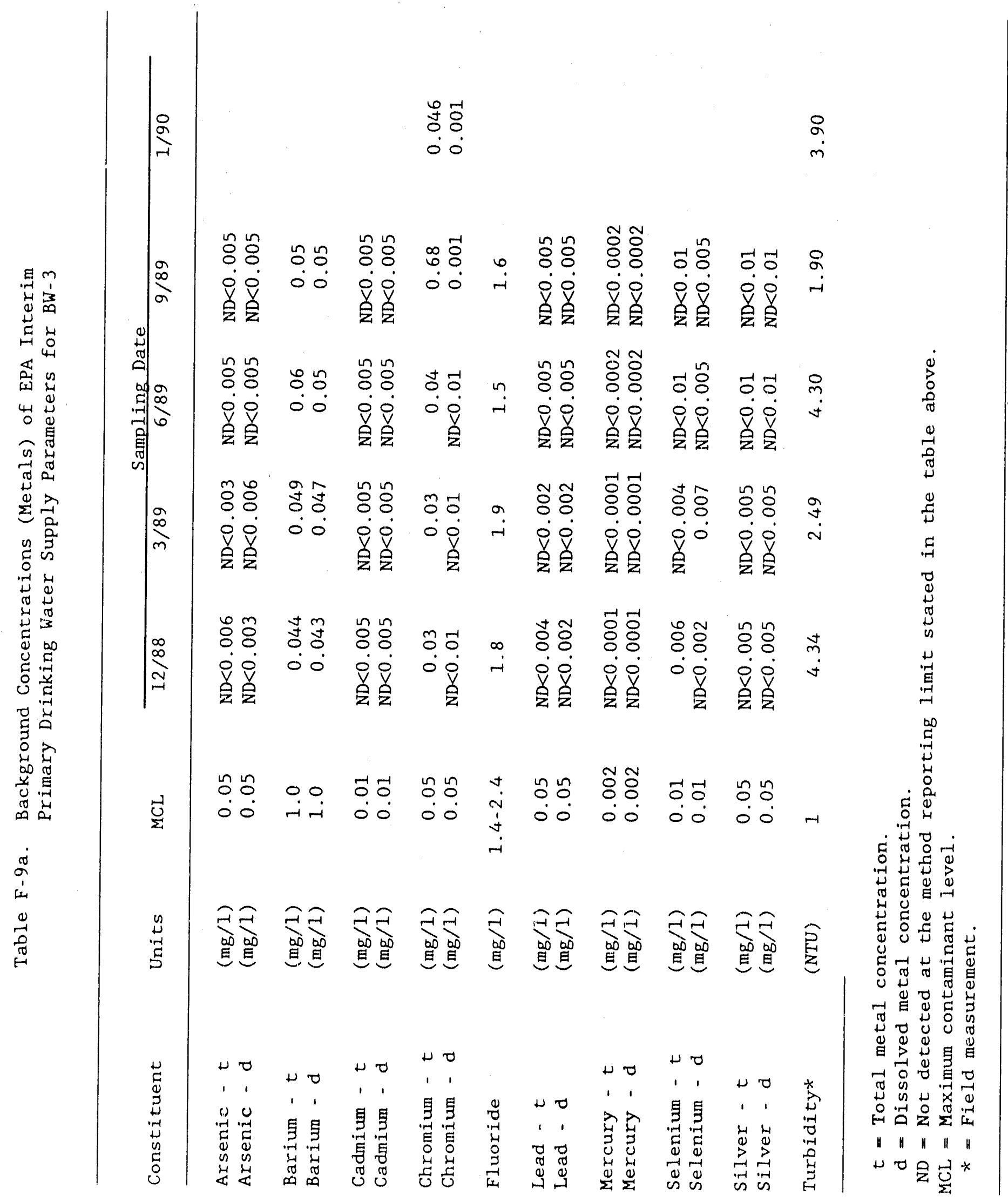




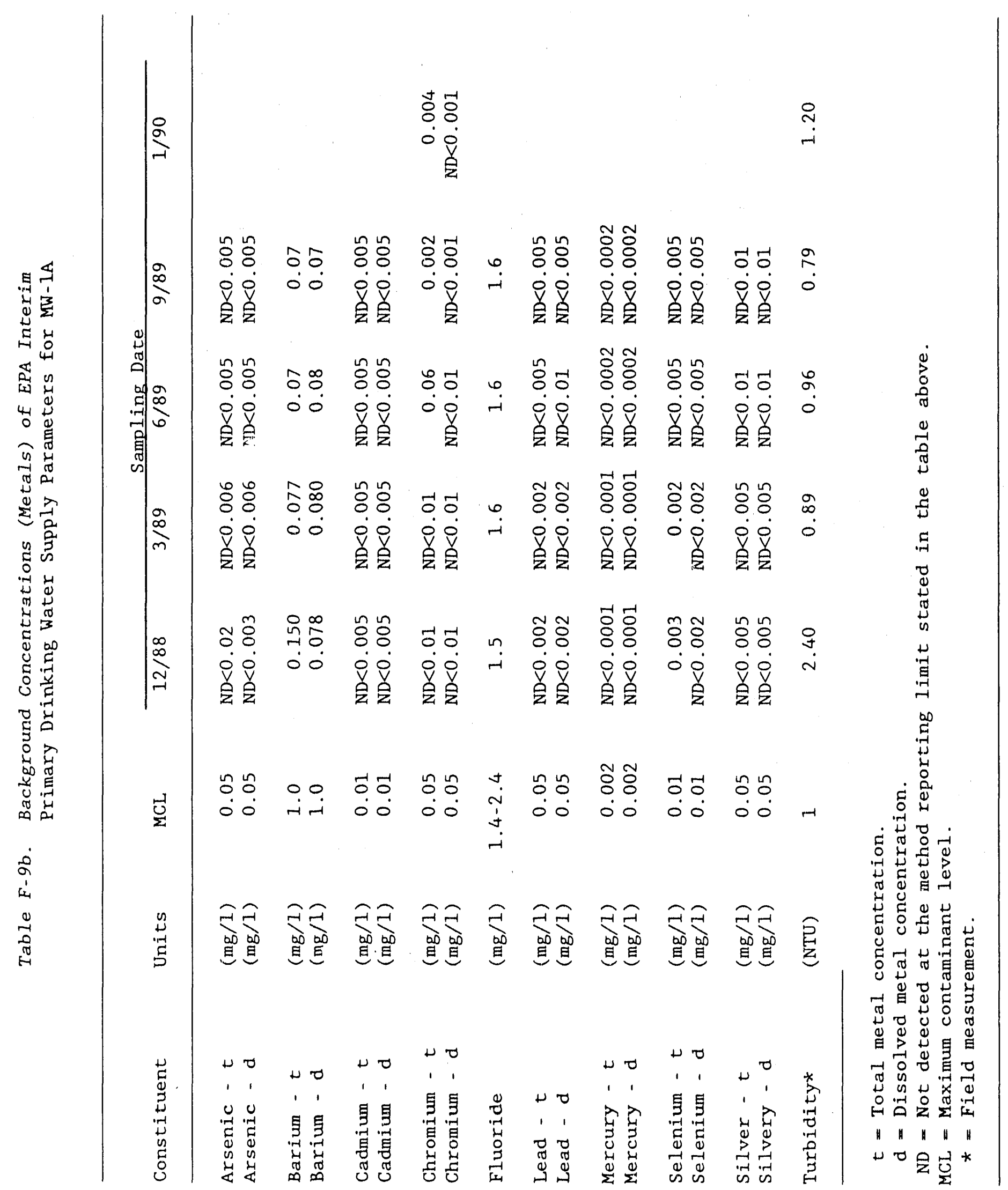




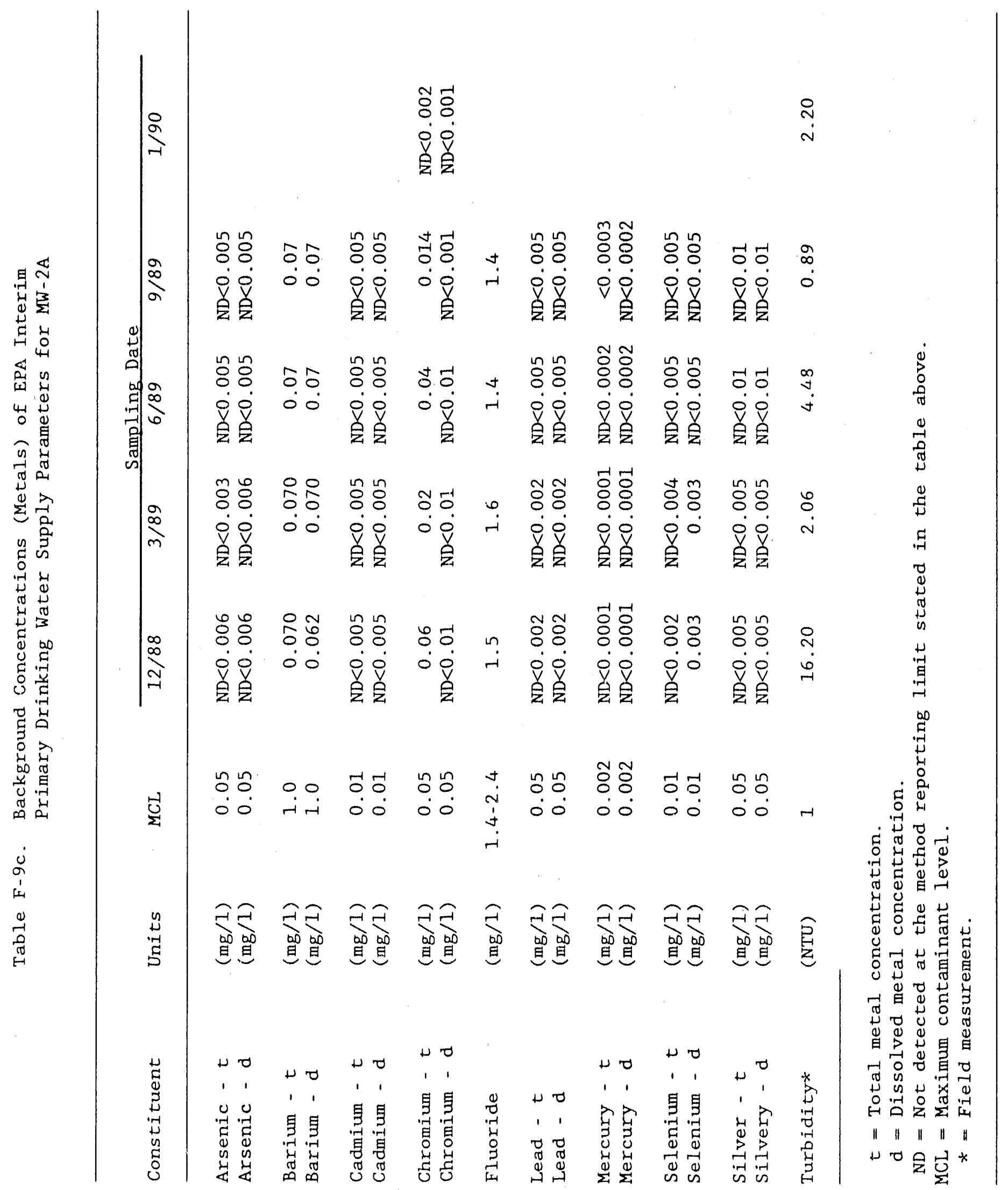




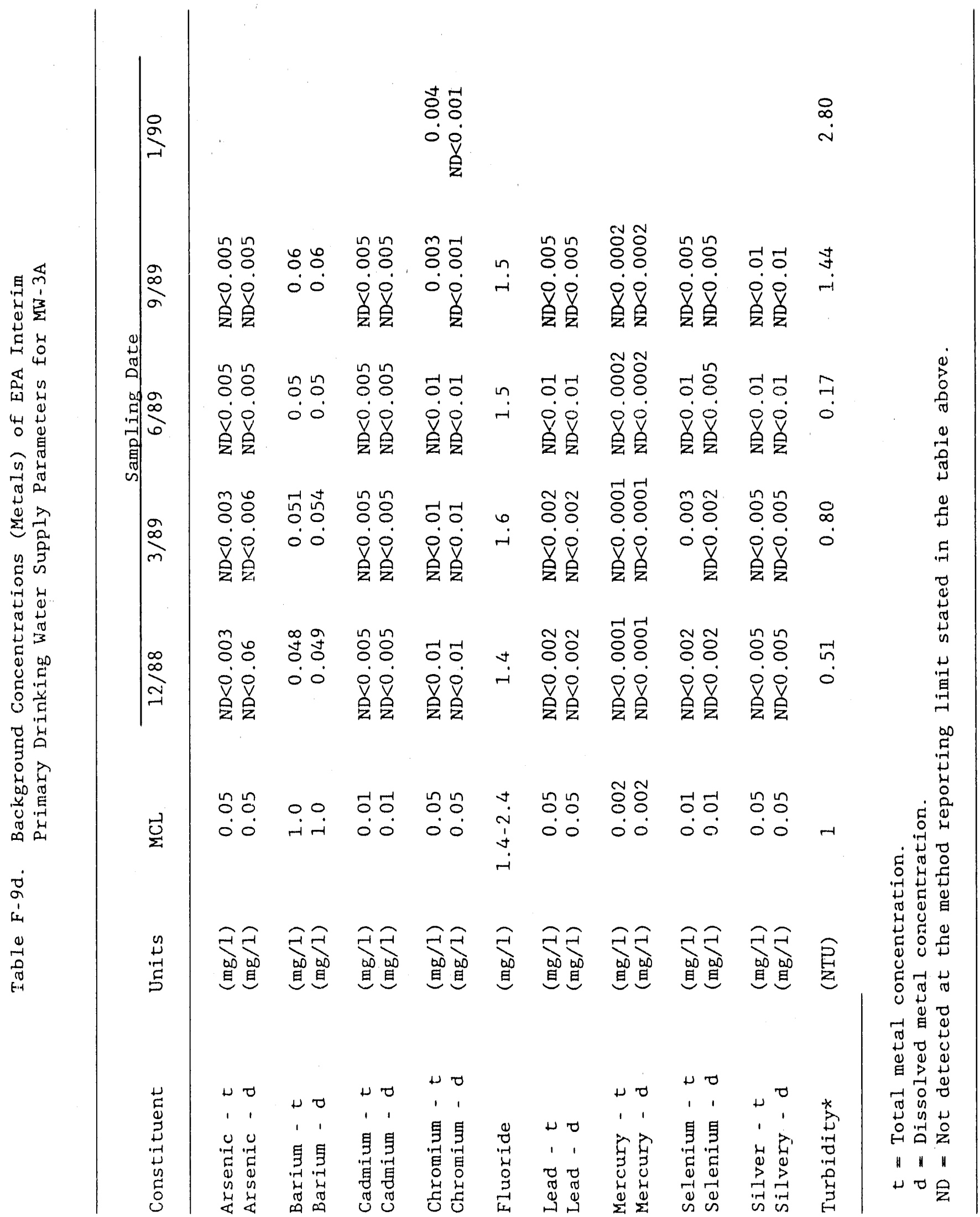




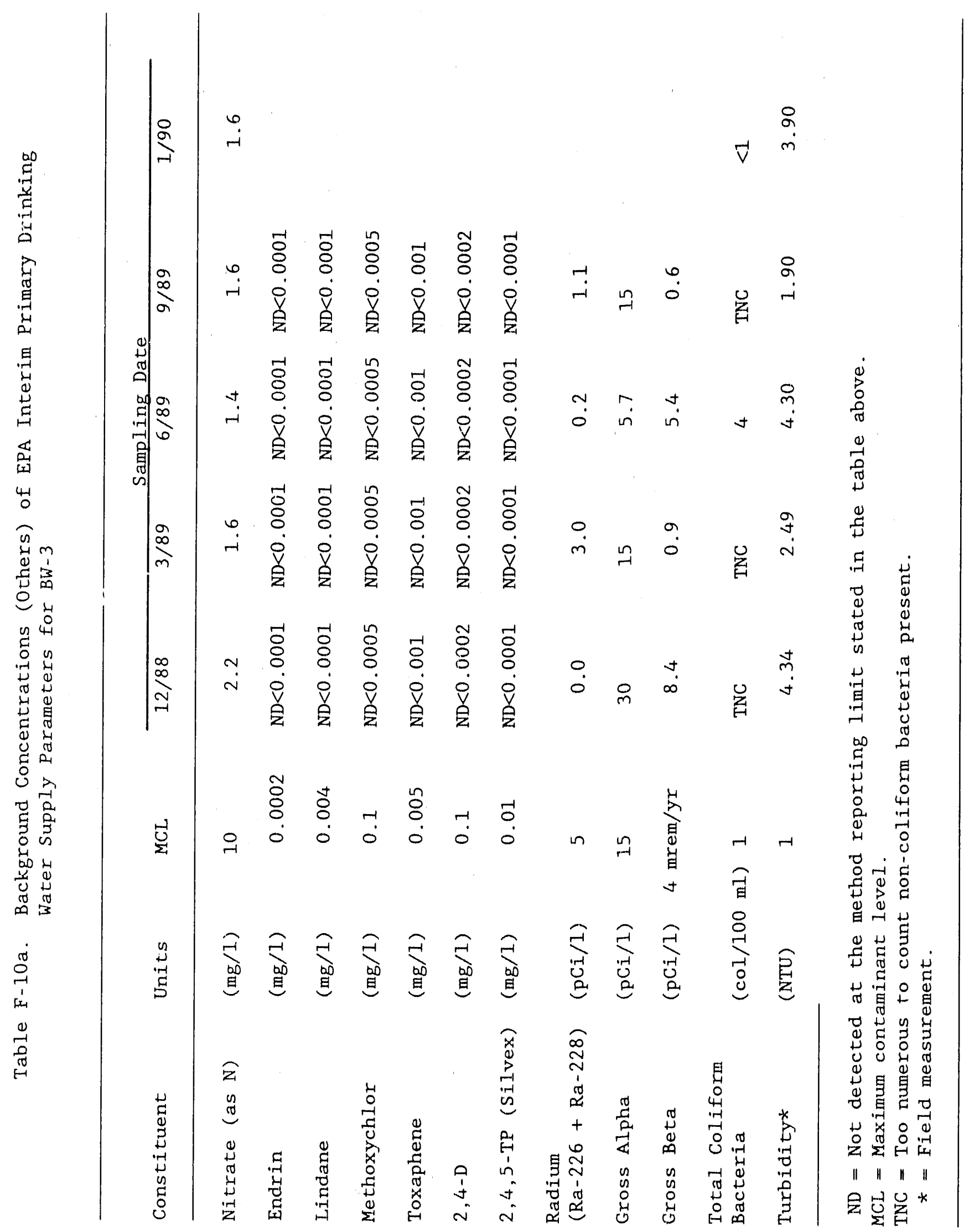




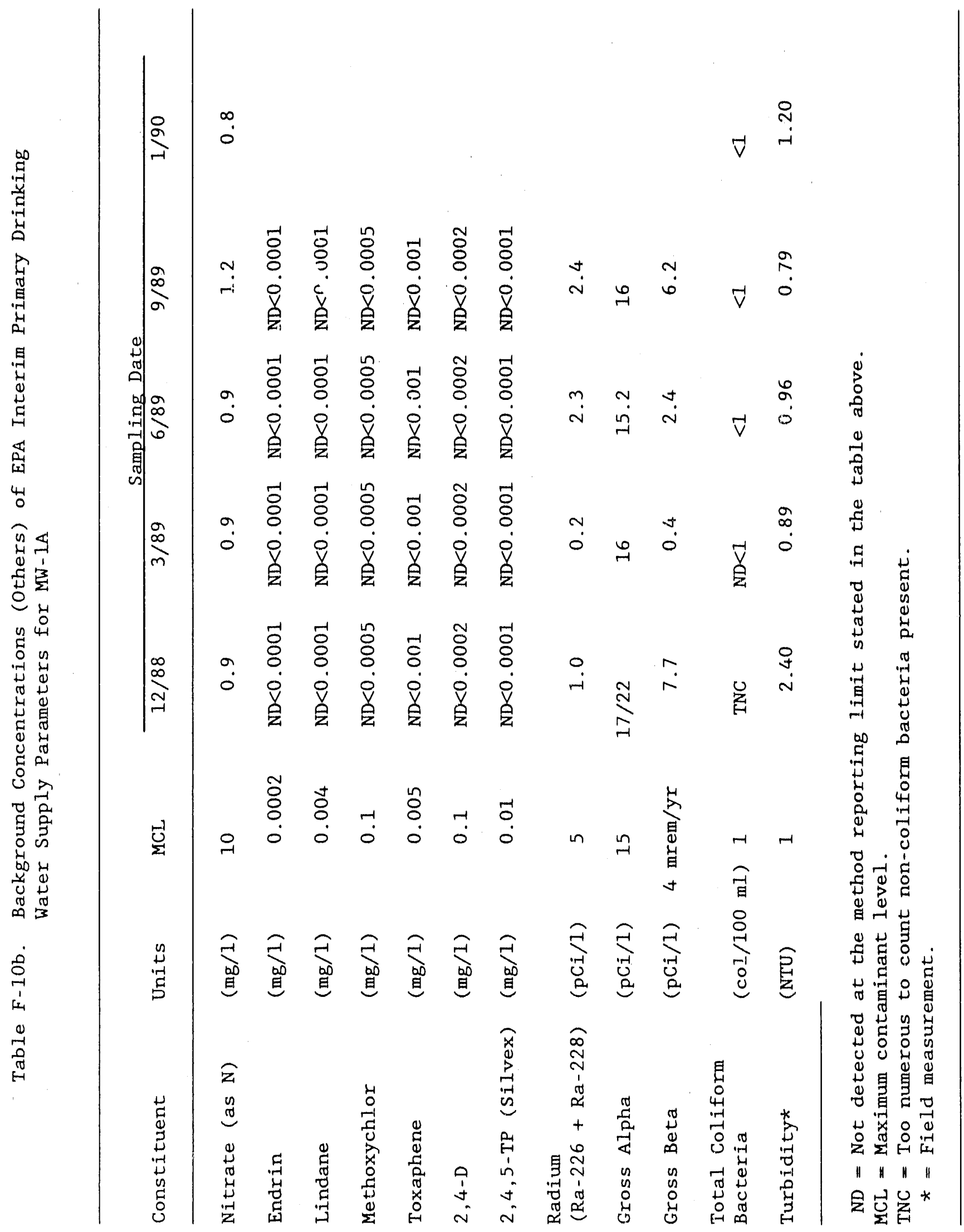




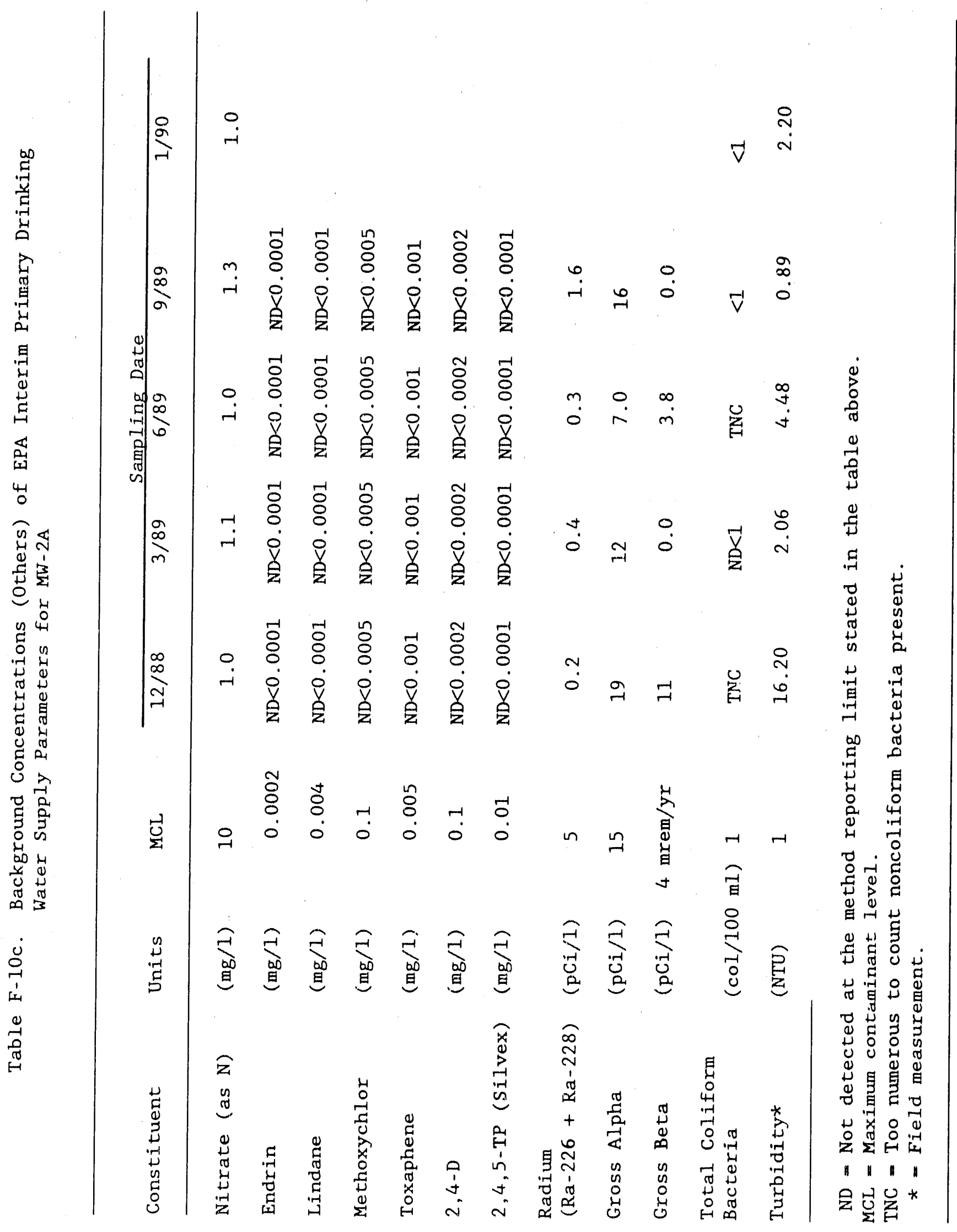




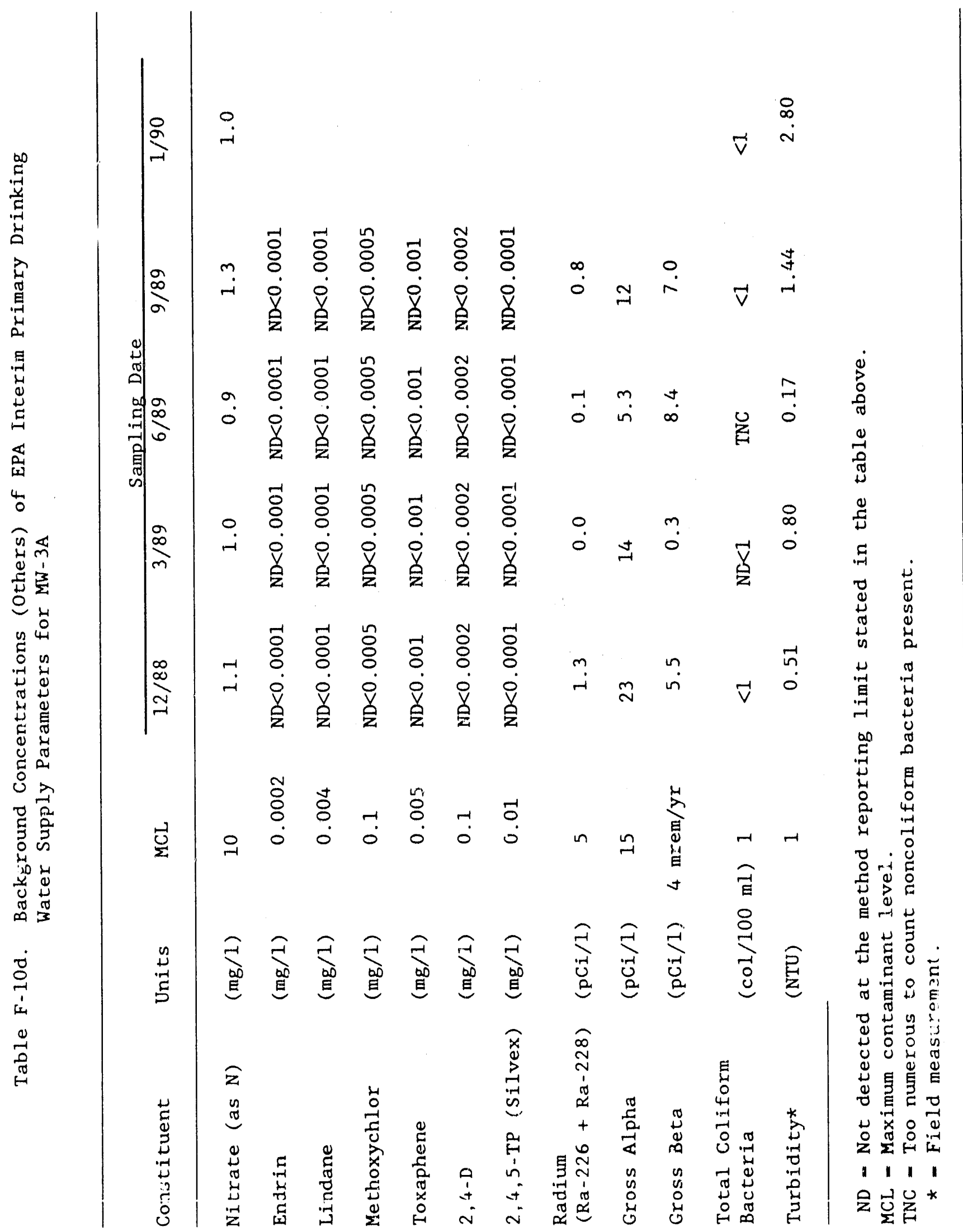




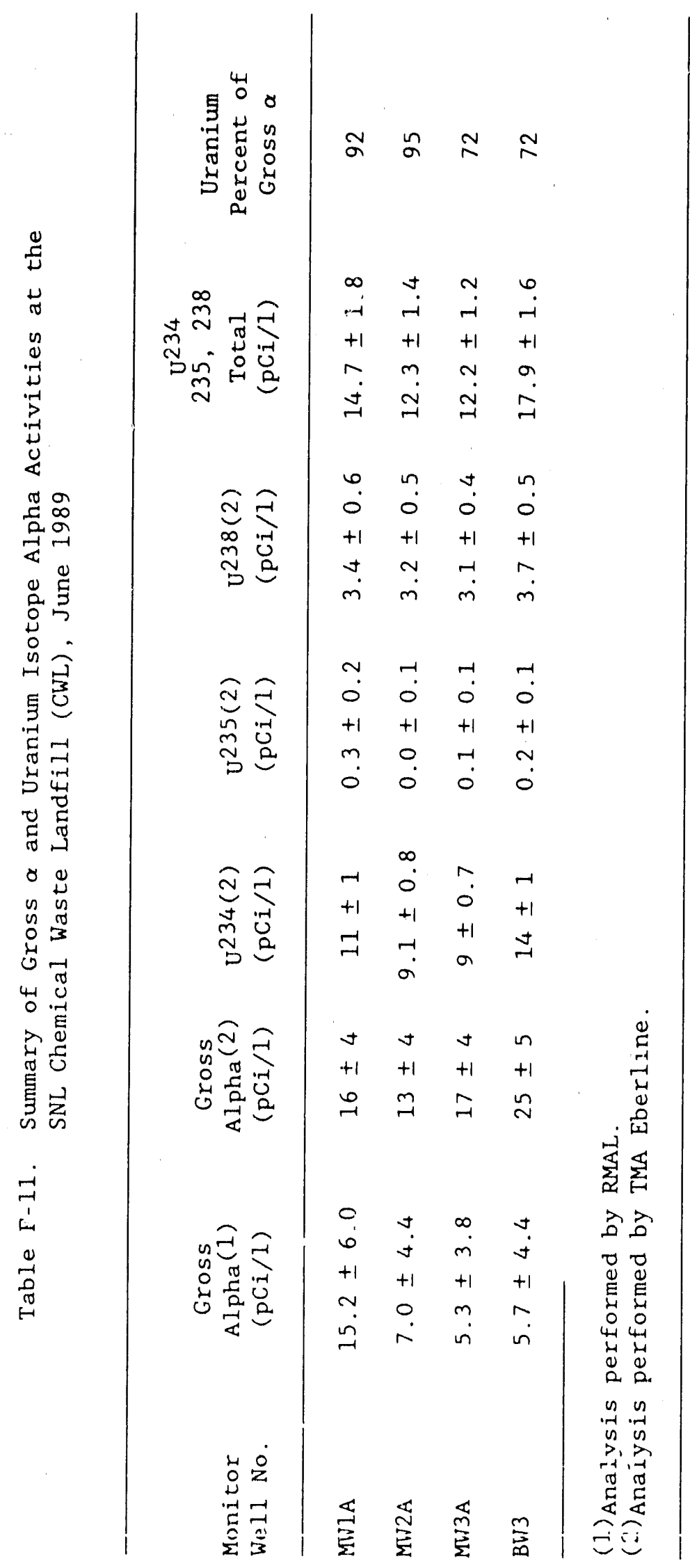


1989 ENVIRONMENTAL MONITORING REPORT,

SANDIA NATIONAL LABORATORIES, ALBUQUERQUE

Table F-12. Summary of Uranjum Isotope Mass Distribution, SNL Chemical Waste Landfill (CWL), June 1989

\begin{tabular}{|c|c|c|c|}
\hline Well & $\begin{array}{c}\text { Percent } \\
U-238\end{array}$ & $\begin{array}{c}\text { Percent } \\
\mathrm{U}-235\end{array}$ & $\begin{array}{c}\text { Percent } \\
U-234\end{array}$ \\
\hline MWIA & 98.63 & 1.35 & 0.02 \\
\hline MW2A & 99.50 & 0.48 & 0.02 \\
\hline MW3A & 99.50 & 0.49 & 0.01 \\
\hline BW3 & 99.14 & 0.84 & 0.02 \\
\hline $\begin{array}{l}\text { Equilibrium ( } 1) \\
\text { Distribution }\end{array}$ & 99.27 & 0.72 & 0.01 \\
\hline $\begin{array}{l}\text { (1) Chart of th } \\
\text { Energy, Thi }\end{array}$ & $\begin{array}{l}\text { ides, } \\
\text { h Editi }\end{array}$ & Power Lal & S. Department of \\
\hline
\end{tabular}


Table F-13. Summary of Four-Day Averages of Analytical Results for Waste Water Sampling Station WW001, Permit No. 2069A SNL, Albuquerque (All results in $\mathrm{mg} / 1$ unless otherwise noted)

\begin{tabular}{|c|c|c|c|c|c|}
\hline \multirow[b]{2}{*}{ Month } & \multicolumn{5}{|c|}{ Parameter } \\
\hline & $\mathrm{Cd}$ & $\mathrm{Cu}$ & $\mathrm{CN}$ (Total) & $\mathrm{Pb}$ & $\mathrm{Zn}$ \\
\hline January & $<0.005$ & 0.03 & $<0.01$ & $<0.02$ & 0.42 \\
\hline February & $<0.005$ & 0.04 & $<0.036$ & $<0.02$ & 0.19 \\
\hline March & $<0.005$ & $<0.02$ & $<0.02$ & $<0.02$ & 0.28 \\
\hline April & $<0.005$ & $<0.02$ & $<0.01$ & $<0.02$ & 0.24 \\
\hline May & $<0.005$ & $\therefore 0.02$ & $<0.010$ & $<0.02$ & 0.26 \\
\hline June & $<0.01$ & $<0.02$ & $<0.036$ & $<0.02$ & 0.29 \\
\hline July & $<0.005$ & $<0.02$ & $*$ & $<0.02$ & 0.25 \\
\hline August & $<0.005$ & 0.05 & $<0.010$ & $<0.02$ & 0.34 \\
\hline September & $<0.005$ & 0.06 & $<0.01$ & $<0.02$ & 0.17 \\
\hline October & $<0.005$ & 0.06 & $<0.01$ & $<0.02$ & 0.30 \\
\hline November & $<0.005$ & 0.06 & 0.018 & $<0.02$ & 0.28 \\
\hline December & $<0.005$ & 0.23 & $<0.01$ & $<0.02$ & 0.36 \\
\hline
\end{tabular}


1989 ENIIPONMENTAL MONITORING REPORT,

SANDIA NATIIONAL LABORATORIES, ALBUQUERQUE

Table F-14. Summary of Four-Day Averages of Analytical Results for Wastewater Sampling Station WW003, Permit No. 2069C-2 $\mathrm{SNL}$, Albuquerque (All results in $\mathrm{mg} / 1$ unless otherwise noted)

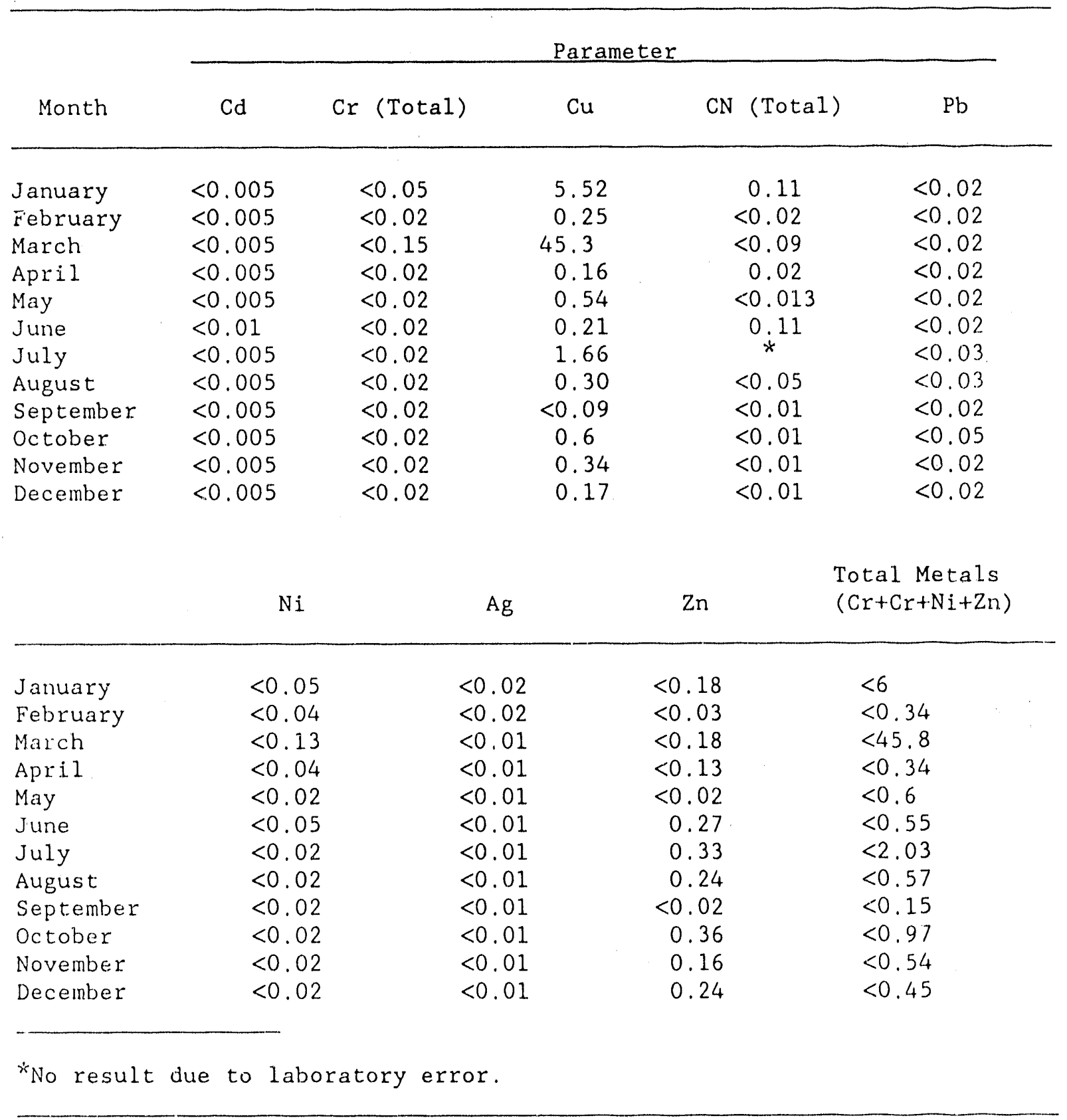


Table F-15. Summary of Four-Day Averages of Analytical Results for Wastewater Sampling Station WW004, Permit No. 2069D-2 SNL, Albuquerque (All results in $\mathrm{mg} / \mathrm{l}$ unless otherwise noted)

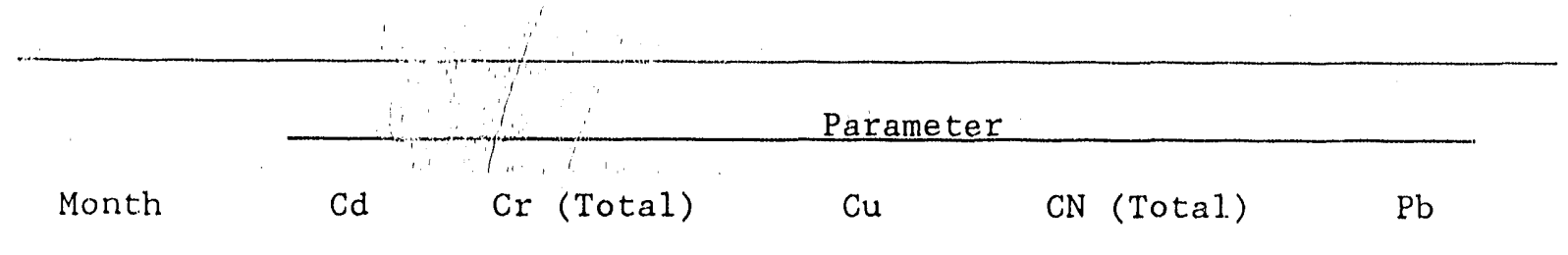

$\begin{array}{lcrrrr}\text { January } & <0.01 & <0.05 & 0.05 & 0.02 & <0.02 \\ \text { February } & <0.005 & <0.02 & <0.04 & <0.01 & <0.02 \\ \text { March } & <0.005 & <0.04 & 0.08 & <0.02 & <0.02 \\ \text { April } & <0.011 & <0.03 & 0.03 & <0.03 & <0.02 \\ \text { May } & 0.017 & <0.05 & 0.03 & <0.010 & <0.02 \\ \text { June } & <0.01 & <0.05 & 0.09 & <0.010 & <0.02 \\ \text { July } & <0.006 & <0.05 & <0.03 & * & <0.02 \\ \text { August } & <0.005 & <0.02 & 0.03 & <0.01 & <0.02 \\ \text { September } & <0.009 & <0.02 & <0.03 & <0.01 & <0.02 \\ \text { October } & <0.005 & <0.02 & <0.03 & <0.01 & <0.02 \\ \text { November } & <0.005 & <0.02 & 0.04 & <0.01 & <0.02 \\ \text { December } & <0.005 & <0.05 & 0.16 & <0.01 & <0.02\end{array}$
$\mathrm{Ni}$
$\mathrm{Ag}$
$\mathrm{Zn}$
Total Toxic Organics (TTO)

\begin{tabular}{lllll}
\hline & & & & \\
January & $<0.09$ & $<0.02$ & $<0.02$ & NR \\
February & $<0.04$ & $<0.02$ & $<0.03$ & NR \\
March & $<0.05$ & $<0.01$ & $<0.02$ & NR \\
April & $<0.04$ & $<0.01$ & $<0.02$ & NR \\
May & $<0.04$ & $<0.01$ & $<0.02$ & NR \\
June & $<0.05$ & $<0.01$ & $<0.02$ & NR \\
July & $<0.03$ & $<0.01$ & $<0.10$ & NR \\
August & $<0.02$ & $<0.01$ & $<0.02$ & NR \\
September & $<0.04$ & $<0.01$ & $<0.02$ & NR \\
October & $<0.02$ & $<0.01$ & $<0.02$ & NR \\
November & $<0.02$ & $<0.01$ & 0.02 & NR \\
December & $<0.02$ & $<0.01$ & 0.02 & \\
& & & & \\
\hline * No result due & to & & & \\
&
\end{tabular}


Table F-16. Summary of Four-Day Averages of Analytical Results for Wastewater Sampling Station WW005, Permit No. 2069E-2 $\mathrm{SNL}$, Albuquerque (A11 results in $\mathrm{mg} / 1$ unless otherwise noted)

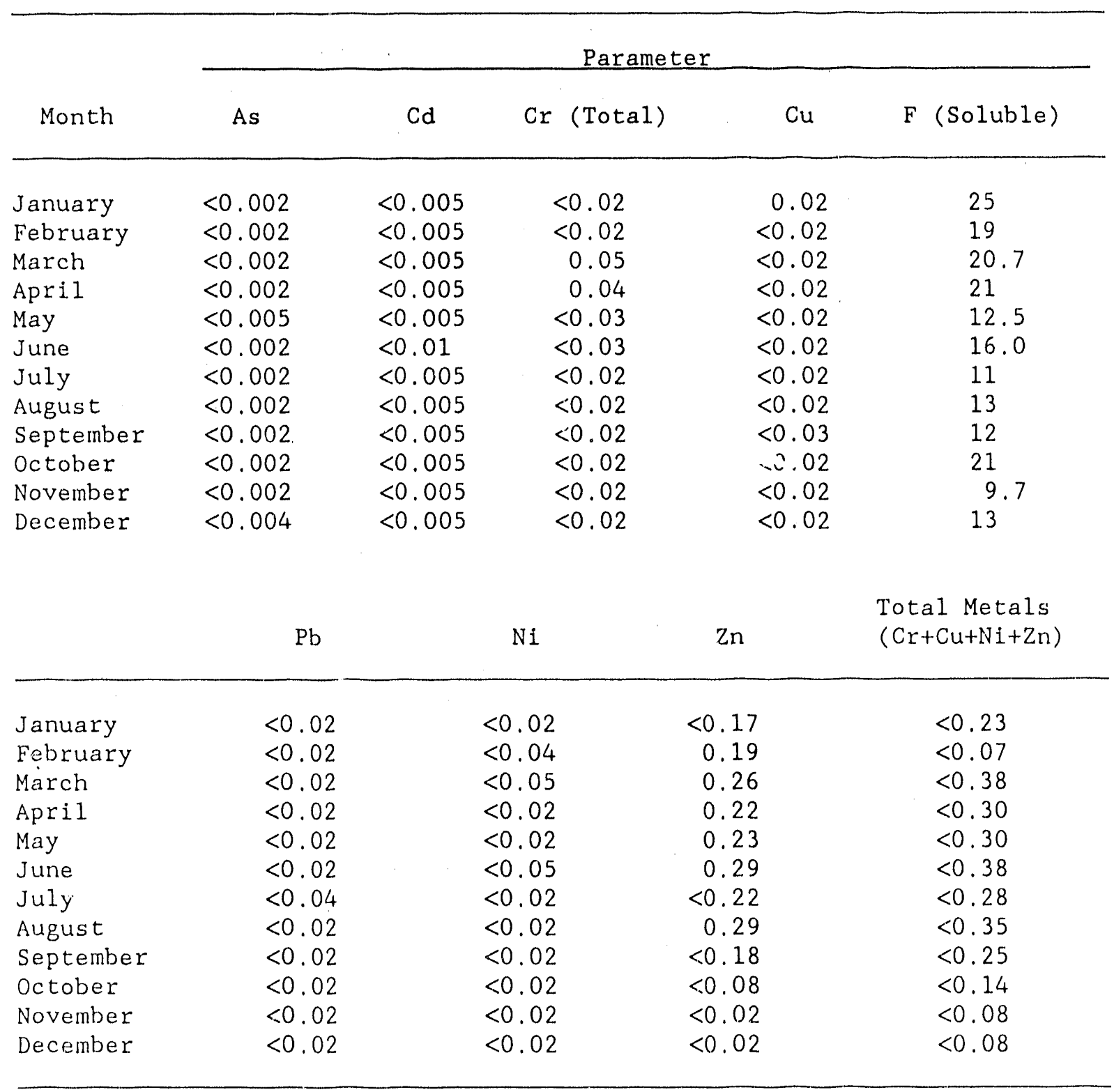


Table F-17. Summary of Four-Day Averages of Analytical Results for Wastewater Sampling Station WW006, Permit No. 2069F SNL, Albuquerque (All. results in $\mathrm{mg} / \mathrm{l}$ unless otherwise noted)

\begin{tabular}{lccccc}
\hline & \multicolumn{5}{c}{ Parameter } \\
\cline { 2 - 6 } \multicolumn{1}{c}{ Month } & $\mathrm{Cd}$ & $\mathrm{Cu}$ & $\mathrm{CN}$ (Tota1) & $\mathrm{Pb}$ & $\mathrm{Zn}$ \\
\hline & & & & \\
\hline January & $<0.005$ & 0.06 & 0.02 & $<0.02$ & 1.8 \\
February & $<0.005$ & 0.07 & $<0.01$ & $<0.02$ & 0.22 \\
March & $<0.000$ & 0.09 & 0.02 & $<0.02$ & 0.33 \\
Apri1 & $<0.005$ & 0.08 & $<0.02$ & $<0.02$ & 0.27 \\
May & $<0.005$ & 0.06 & $<0.011$ & $<0.02$ & 0.27 \\
June & $<0.01$ & 0.07 & $<0.020$ & $<0.02$ & 0.29 \\
July & $<0.005$ & 0.12 & $*$ & $<0.02$ & 0.34 \\
August & $<0.005$ & 0.06 & $<0.010$ & $<0.02$ & 0.34 \\
September & $<0.005$ & 0.06 & $<0.011$ & $<0.02$ & 0.29 \\
October & $<0.005$ & 0.07 & $<0.01$ & $<0.02$ & 2.0 \\
November & $<0.005$ & 0.06 & 0.017 & $<0.02$ & 0.30 \\
December & $<0.005$ & 0.10 & $<0.01$ & $<0.02$ & 0.29 \\
& & & & & \\
*No result due to 1aboratory error. & & & \\
\hline
\end{tabular}


Table F-18. Summary of Four-Day Averages of Analytical Results for Wastewater Sampling Station WW007, Pe:mit No. 2069G SNL, Albuquerque (All results in $\mathrm{mg} / \mathrm{l}$ unless otherwise noted)

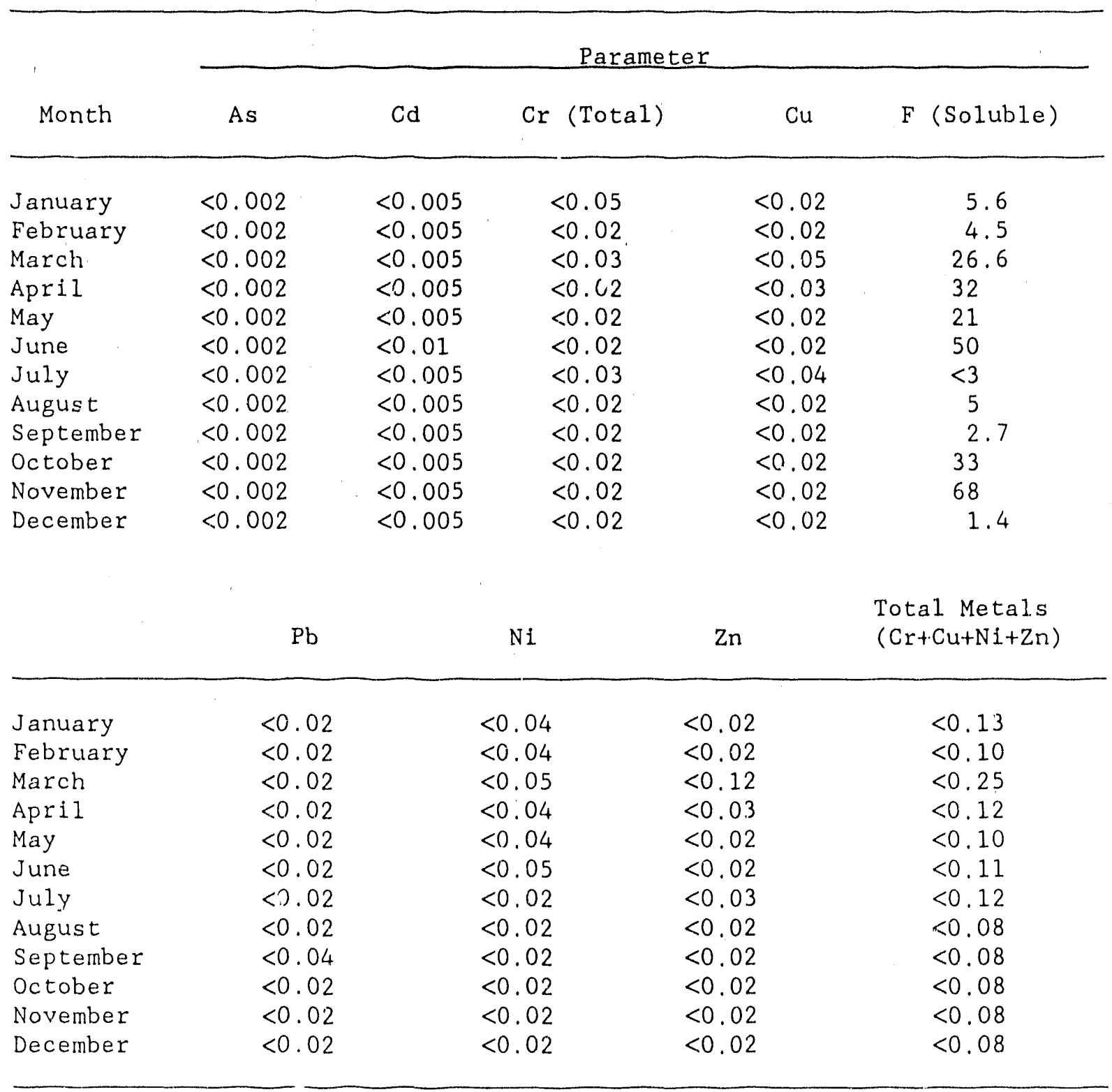




\section{REFERENCES}

U.S. Department of Energy (DOE), 1990. "Radiation Protection of the Public and the Environment," DOE Order 5400.5, DOE, February 1990. 


\section{APPENDIX G}

\section{ENVIRONMENTAL REGULATIONS AND STANDARDS}


Table G-1. Radiation Standards 1 for Protection of the Public in the Vicinity of DOE Facilities for CY 89

\section{Dose Limits}

\section{Al1 Pathways}

The effective dose equivalent for any member of the public from all routine DOE operations ${ }^{2}$ (natural background and medical exposures excluded) shall not exceed the values given below:

$\frac{\text { Effective Dose Equivalent } 3}{\text { mrem/year (mSv/year) }}$

Occasional annual exposures $\quad 500$

Prolonged period of exposure $4 \quad 100 \quad$ (1)

No individual organ shall receive a committed effective dose equivalent of $5 \mathrm{rem} /$ year ( $50 \mathrm{mSv} /$ year) or greater.

Air Pathway

Maximum off-site residence

Whole body dose

Critical organ $\frac{\text { Dose Equivalent } 5}{\text { mrem/year (mSv/year) }}$

$25 \quad(0.25)$

$75 \quad(0.75)$

$1_{\text {DOE }}$ interim standards, Memorandum, dated August 5, 1985.

2Routine DOE operations means normal planned operations and do not include actual or potential accidental or unplanned releases.

${ }^{3}$ Effective dose equivalent will be expressed in rem (or millirem) with we corresponding value in sievert (or millisievert) in parenthesis.

4 For the purposes of these standards, a prolonged exposure will be one that lasts, or is predicted to last, longer than 5 years.

5 The regulation was revised on December 15, 1989. The new standard with dosa limit of $10 \mathrm{mrem}$ (effective dose equivalent) will be applied to all DOE operations starting CY90. 
Table G-2. Derived Concentration Guides (DCG) For Selected Radionuclides 1

\begin{tabular}{|c|c|c|c|c|}
\hline \multirow[b]{2}{*}{ Nuclide } & \multicolumn{2}{|c|}{ Drinking Water } & \multicolumn{2}{|c|}{ Inhaled A1 $x^{4}$} \\
\hline & $\begin{array}{c}\text { DCG } \\
\mu \mathrm{Ci} / \mathrm{L}\end{array}$ & $\begin{array}{c}f, \\
\text { Value }\end{array}$ & $\begin{array}{c}\text { DCG } \\
\mu \mathrm{C} 1 / \mathrm{m}^{3}\end{array}$ & $\begin{array}{l}\text { Solubility } \\
\text { Class }\end{array}$ \\
\hline 3H (Water) & $2 E+00$ & - & $1 \mathrm{E}-01$ & - \\
\hline $137 \mathrm{Cs}$ & $3 E-03$ & $1 E+00$ & $4 E-04$ & D \\
\hline Gross $\alpha^{2}$ & $15 E-06$ & - & - & " \\
\hline $\operatorname{Gross} \beta^{2}$ & $3 E-05$ & - & - & - \\
\hline Total $U(\text { nat })^{3}$ & $6 \mathrm{E}-04$ & - & $6 E-6$ & - \\
\hline \multicolumn{5}{|c|}{$\begin{array}{l}\text { 1USDOE Memorandum from Robert } \mathrm{J} \text {. Stern, dater February } 28,1986 \text { (Stern, } \\
\text { 1986). } \\
\text { 2USEPA National Interim Primary Drinking Water Regulations } \\
\text { EPA-570/9-76-003) } \\
3 \text { One curie of natural uranium is equivalent to } 3,000 \mathrm{~kg} \text { of natural uranium. } \\
\text { A conversion from } \mu \mathrm{g} \text { to } \mu \mathrm{Ci} \text { may be made by multiplying } \mu \mathrm{g} \text { by } 3.3 \times 10^{-7} \text {. } \\
4 \text { DCG for } 3 \mathrm{H} \text { in air }(2 \mathrm{E}-01) \text { is adjusted for skin absorption. }\end{array}$} \\
\hline
\end{tabular}


Table G-3. Groundwater Monitoring Parameters Required by 40 CFR Part 265, Subpart F

Parameter*

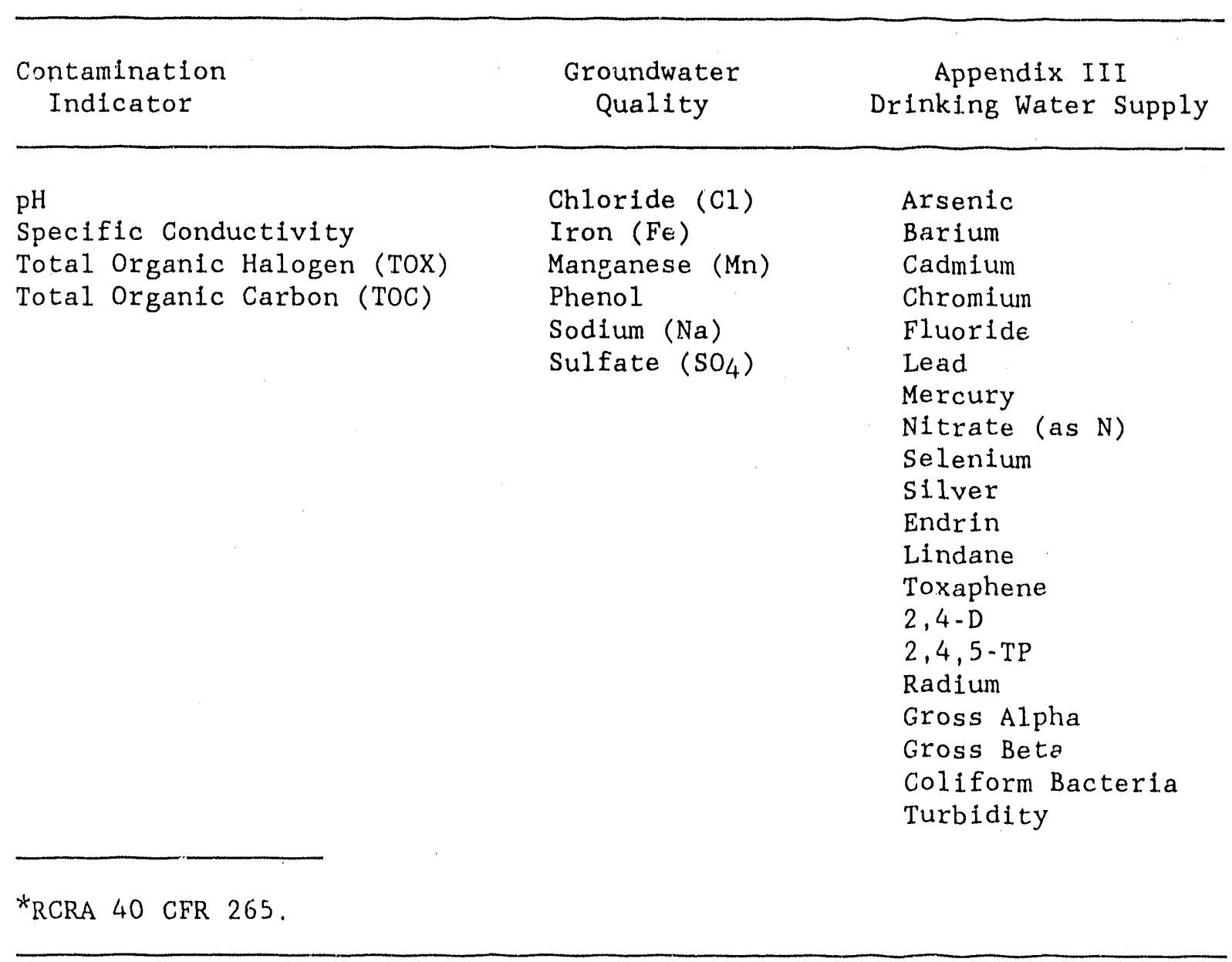


Table G-4. EPA Interim Primary Drinking Water Supply Parameters

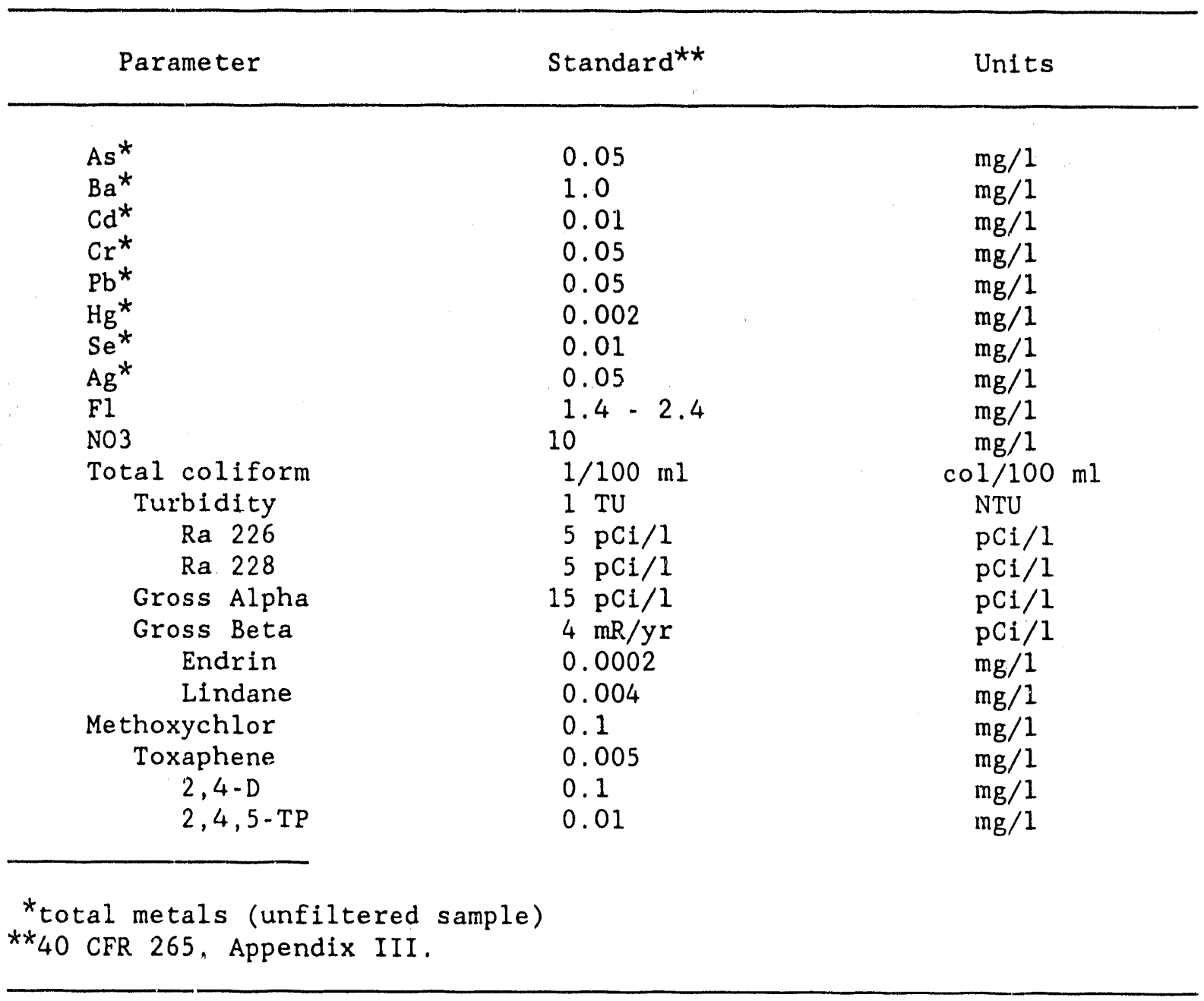




\section{REFERENCES}

U.S. Department of Energy (DOE), 1990. "Derived Concentration Guide for Air and Water," Chapter 3, DOE Order 5400.5, DOE, February 1990.

U.S. Environmental Protection Agency (EPA), "USEPA National Interim Primary Drinking Water Regulations," EPA-570/9-76-003. 


\section{APPENDIX H \\ OTHER ENVIRONMENTAL COMPLIANCE RECORDS}

H- $-1 / 2$ 
Table H-1. SNL, Albuquerque, Underground Storage Tanks (USTs) Closed in 1989

\begin{tabular}{lrll}
\hline Tank I.D. & Capacity & \multicolumn{1}{c}{ Contents } & Date Closed \\
\hline $840-1$ & $500 \mathrm{Gal}$ & Machining Fluids & $01 / 01 / 89$ \\
$9970-1$ & $500 \mathrm{Gal}$ & Fuel Oil & $06 / 15 / 89$ \\
$6720 / 1-1$ & $500 \mathrm{Gal}$ & Fuel 0il & $06 / 23 / 89$ \\
$6581-1$ & $500 \mathrm{Gal}$ & Fuel Oil & $07 / 03 / 89$ \\
$6536-1$ & $25,000 \mathrm{Gal}$ & Fuel Oil & $07 / 26 / 89$ \\
$9832-1$ & $650 \mathrm{Gal}$ & Fuel Oil & $07 / 28 / 89$ \\
$6596-5$ & $1,000 \mathrm{Gal}$ & Fuel Oil & $08 / 30 / 89$ \\
$6018-1$ & $500 \mathrm{Gal}$ & Diesel & $10 / 10 / 89$ \\
& & & \\
\hline
\end{tabular}


Table H-2. SNL, Albuquerque, USTs Registered as of 12/31/89

\begin{tabular}{|c|c|c|c|}
\hline Tank I.D. & Capacity & Contents & Year Irstalled \\
\hline $605-7$ & $1,000 \mathrm{Gal}$ & Fuel 011 & 1968 \\
\hline $605-8$ & $12,000 \mathrm{Gal}$ & Fuel 011 & 1956 \\
\hline $605-9$ & $12,000 \mathrm{Gal}$ & Fuel 011 & 1956 \\
\hline $605-10$ & $12,000 \mathrm{Gal}$ & Fuel $0 i 1$ & 1956 \\
\hline $605-11$ & $12,000 \mathrm{Ga} 1$ & Fuel 011 & 1956 \\
\hline $844-1$ & $150 \mathrm{Gal}$ & Tritiated Water & 1968 \\
\hline $862-1$ & $9,730 \mathrm{Gal}$ & Diesel & 1987 \\
\hline $867-1$ & $4,000 \mathrm{Gal}$ & Neutralization Tank & 1973 \\
\hline $876-1$ & $1,000 \mathrm{Gal}$ & Waste 011 & 1950 \\
\hline $876-2$ & $12,000 \mathrm{Gal}$ & Gasoline & 1985 \\
\hline $876-3$ & $12,000 \mathrm{Gal}$ & Diesel & 1986 \\
\hline $888-1$ & $550 \mathrm{Gal}$ & Waste Oil & 1979 \\
\hline $888-2$ & $550 \mathrm{Gal}$ & Waste Oil & 1979 \\
\hline $888-3$ & $20,000 \mathrm{Gal}$ & Transformer Oil & 1982 \\
\hline $888-4$ & $20,000 \mathrm{Gal}$ & Transformer oil & 1982 \\
\hline $888-5$ & $20,000 \mathrm{Gal}$ & Transformer Oil & 1982 \\
\hline $888-6$ & $20,000 \mathrm{Gal}$ & Transformer Oil & 1982 \\
\hline $901-1$ & $120 \mathrm{Gal}$ & Gasoline & 1951 \\
\hline $910-1$ & $120 \mathrm{Gal}$ & Gasoline & 1951 \\
\hline $911-1$ & $120 \mathrm{Gal}$ & Gasoline & 1951 \\
\hline $912-1$ & $120 \mathrm{Gal}$ & Gasoline & 1951 \\
\hline $970-1$ & $1,000 \mathrm{Gal}$ & Fuel 011 & 1987 \\
\hline $970-3$ & $1,000 \mathrm{Gal}$ & Waste Oil & 1987 \\
\hline $983-8$ & $60,000 \mathrm{Gal}$ & Bromine Water & 1986 \\
\hline $983-9$ & $2,000 \mathrm{Gal}$ & Waste Oil & 1985 \\
\hline $6028-1$ & $5,000 \mathrm{Gal}$ & Gasoline & 1987 \\
\hline $6500-1$ & $600 \mathrm{Gal}$ & Fuel oil & 1978 \\
\hline $6505-1$ & $300 \mathrm{Gal}$ & Fuel oil & 1956 \\
\hline $6525-1$ & $500 \mathrm{Gal}$ & Fuel Oil & Unknown \\
\hline $6580-5$ & 5,000 Gal & Fuel oil & 1958 \\
\hline $6587-2$ & $10,000 \mathrm{Gal}$ & Gasoline & 1963 \\
\hline $6587-3$ & $6,000 \mathrm{Gal}$ & Diesel & 1963 \\
\hline $6588-1$ & $5,000 \mathrm{Gal}$ & Fue1 0il & 1978 \\
\hline $6595-1$ & $34,120 \mathrm{Gal}$ & Transformer Oil & 1968 \\
\hline $6595-2$ & $34,120 \mathrm{Gal}$ & Transformer Oil & 1968 \\
\hline $6595-3$ & $34,120 \mathrm{Gal}$ & Transformer oil & 1968 \\
\hline $6595-4$ & $34,120 \mathrm{Gal}$ & Transformer oil & 1968 \\
\hline $6595-5$ & $34,120 \mathrm{Gal}$ & Transformer Oil & 1968 \\
\hline $6597-2$ & $25,000 \mathrm{Gal}$ & Transformer 0 il & 1978 \\
\hline $6597-3$ & $25,000 \mathrm{Gal}$ & Transformer oil & 1978 \\
\hline $6597-4$ & $25,000 \mathrm{Gal}$ & Transformer oil & 1978 \\
\hline $6597-5$ & $25,000 \mathrm{Gal}$ & Trans former oil & 1978 \\
\hline $6597-6$ & $25,000 \mathrm{Gal}$ & Transformer $0 i l$ & 1978 \\
\hline
\end{tabular}


Table H-2. SNL, Albuquerque, USTs Registered as of 12/31/89 (Concluded)

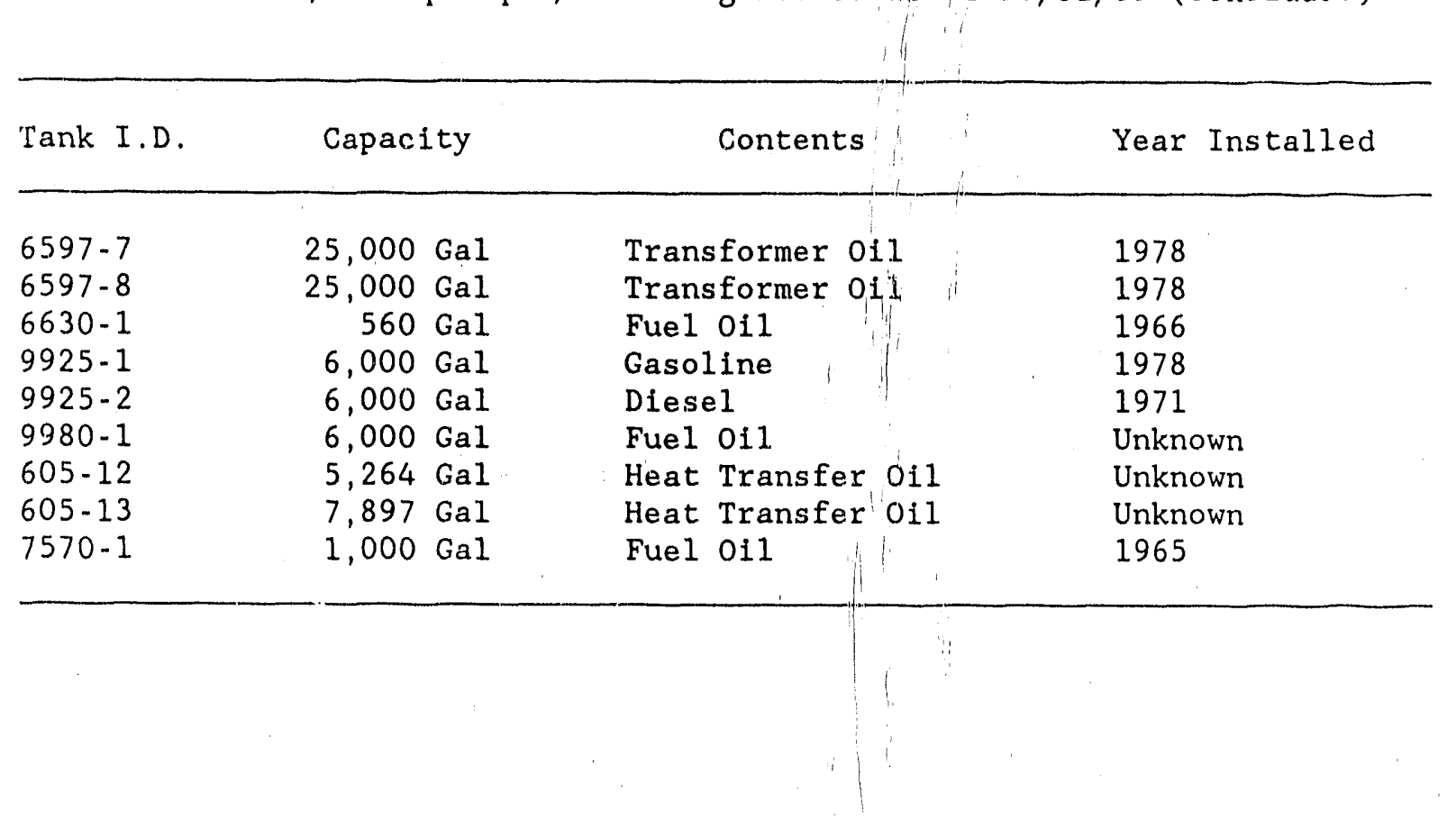


Table H-3. Septic Tank Registration, SNL, Albuquerque

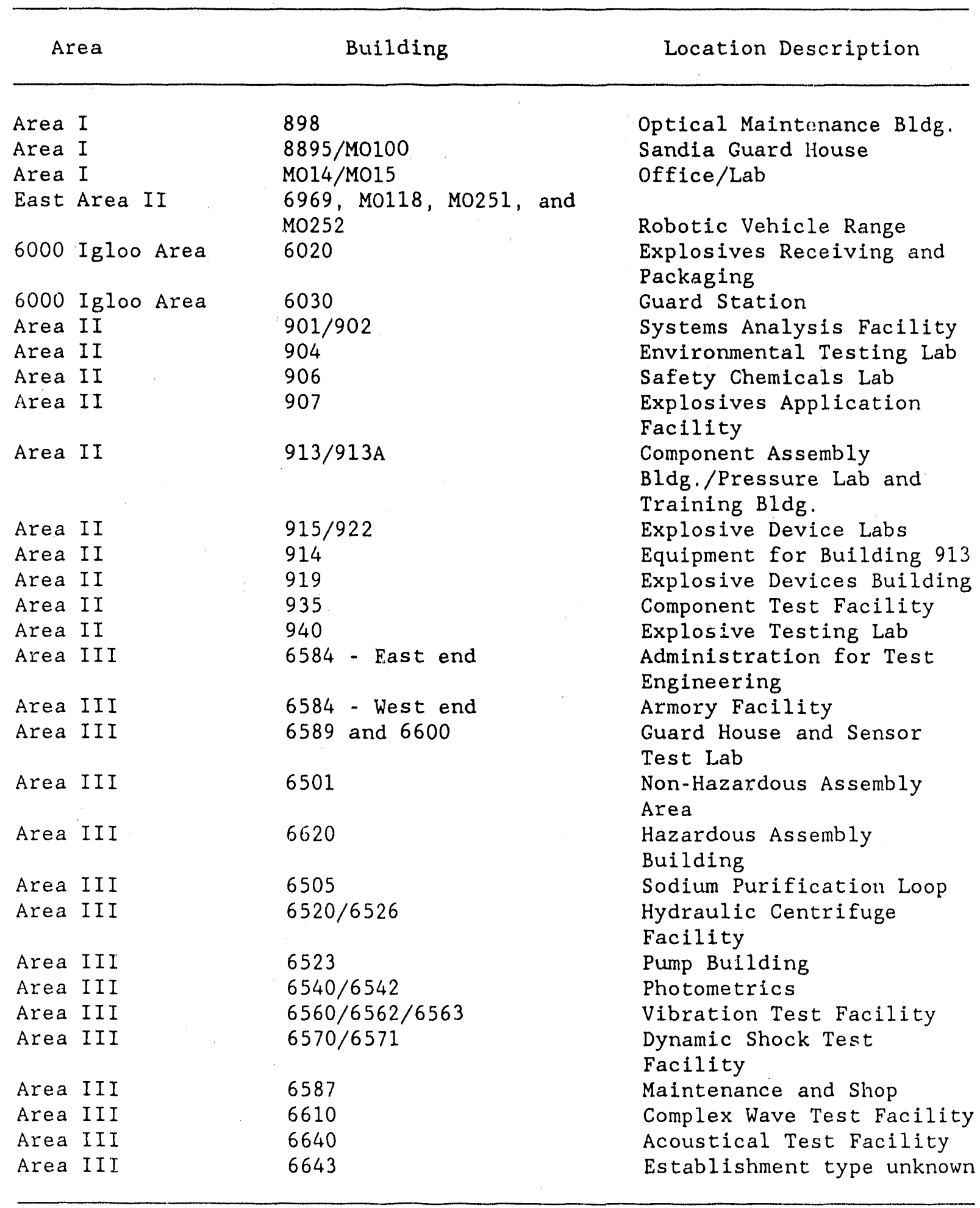


Table H-3. Septic Tank Registration, SNL, Albuquerque (Continued)

\begin{tabular}{|c|c|c|}
\hline Area & Buflding & Iocation Description \\
\hline Area III & 6650 & $\begin{array}{l}\text { Vibration Data Control } \\
\text { Center }\end{array}$ \\
\hline Area III & 6710 & Air Gun Test Facility \\
\hline Area III & 6715 & Explosive Test Facility \\
\hline Area III & 6720 & Irradiated Sludge Facility \\
\hline Area III & 6721 & $\begin{array}{l}\text { Photography/Control for } \\
\text { Bldg. } 6720\end{array}$ \\
\hline Area III & $6730-31 / 6734-35 / \mathrm{M} 0128$ & Dynamic Shock Facility \\
\hline Area III & 6741 & $\begin{array}{l}\text { Control Bldg. for } 5000 \\
\text { Foot Sled Track }\end{array}$ \\
\hline Area III & 6743 & $\begin{array}{l}\text { Rocket Motor Conditioning } \\
\text { Facility }\end{array}$ \\
\hline Area III & 6750 & $\begin{array}{l}\text { Small Arms Range/Impact } \\
\text { Test Facility }\end{array}$ \\
\hline Area III & $\mathrm{T} 12 / \mathrm{T} 42 / \mathrm{T} 43$ & $\mathrm{~N} / \mathrm{A}$ \\
\hline Area III & $\mathrm{T}-52$ & $\mathrm{~N} / \mathrm{A}$ \\
\hline Area III & MO231- 234 & offices \\
\hline Area III & $M 0228-230$ & Offices \\
\hline Area III & MO242- 245 & Offices \\
\hline Area III & 6922 & Explosive Test Facility \\
\hline Area V & $6580 / 6588 / 6590-93 / 6596.97$ & $\begin{array}{l}\text { Reactor Facilities and } \\
\text { Storage }\end{array}$ \\
\hline Area V & $6 ! i 00$ & $\begin{array}{l}\text { Gate House Security } \\
\text { Operations Building }\end{array}$ \\
\hline Area V & $6581-82 / \mathrm{MO} 32 / \mathrm{M057-58}$ & $\begin{array}{l}\text { Febetron } \\
\text { Building/Emergency } \\
\text { Evaluation } \\
\text { Ctr/Offices/Shock Test Lab }\end{array}$ \\
\hline Coyote Area & 9950 & Material Test Lab \\
\hline Coyote Area & 9956 & $\begin{array}{l}\text { Intermediate Velocity Gun } \\
\text { Facility }\end{array}$ \\
\hline Coyote Area & 9965 & $\begin{array}{l}\text { Remote Control Building } \\
\text { for Shock Facility }\end{array}$ \\
\hline Coyote Area & 9967 & He Assembly Building \\
\hline Coyote Area & 9970 & $\begin{array}{l}\text { Antenna Measurement } \\
\text { Facility }\end{array}$ \\
\hline Coyote Area & 9972 & EMP Studies Facility A \\
\hline Coyote Area & 9980 & Solar Tower Facility \\
\hline Coyote Area & $9981 / 9982$ & $\mathrm{~N} / \mathrm{A}$ \\
\hline Coyote Area & Live Fire Range & Live Fire Range \\
\hline Coyote Area & SFER MO127-128/MO130 & $\begin{array}{l}\text { Smal1 Force Engagement } \\
\text { Range }\end{array}$ \\
\hline Coyote Area & 9927 & Explosive Test Facility \\
\hline
\end{tabular}


1989 ENVIRONMENTAL MONITORING REPORT,

SANDIA NATIONAL LABORATORIES, ALBUQUERQUE

Table H-3. Septic Tank Registration, SNL, Albuquerque (Concluded)

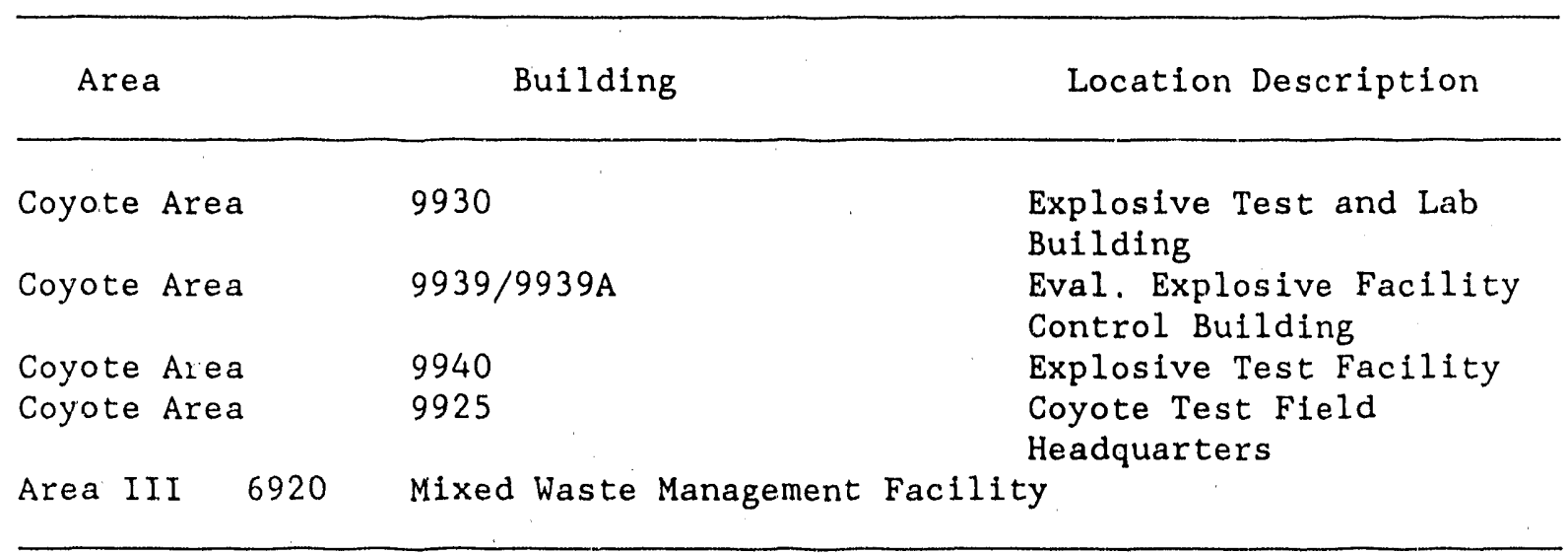


Table H-4. Sandia Environmental Incident Form (Not a Substitute for an "Unusual Occurrence Report")

Part I (Items 1 through 7 )*

1. Date, time, location, and duration of incident.

2. Date and time of notification to Department 3220 and the name of the person consulted.

3. Persons, phone numbers, and organizations performing the activity that caused the incident. Include Supervisor's name, organization, and phone, and the name, organization and phone of the prime contact for this incident.

4. Names, phone numbers, and organizations of other personnel present during the incident.

5. Material and quantity involved; include chemical composition, radionuclide or trade name (attach Material Safety Data Sheet if available).

6. Describe the events leading to the incident.

7. Immediate action taken to mitigate the release.

*Contact Department 3220 for guidance in the use of this form.

Part I must be submitted to 3220 within 24 hours of incident, or on first working day after incident.

Part II must be submitted to 3220 within 2 weeks (10 calender days) of incident. 
Table H-4. Sandia Environmental Incident Form (Continued)

Part II (Items 8 through 14)

8. Describe the medium (e.g., water, asphalt, soil), area, and the depth and area of contamination. Describe the method(s) used to determine this.

9. Name(s) and organization(s) (and contractors) of key personnel responding to the incident.

10. Describe remediation/cleanup activity and the method that will be used to verify completeness of remediation (e.g., monitoring, soil testing, photo-documentation). Include the names of 3220 personnel consulted about remediation.

ii. Approximate labor hours and cost to perform remediation, and organization that is funding the remediation.

12. Proposed short-term corrective action to prevent recurrence, including schedule and estimated cost, and the names of 3220 personnel consulted. 
Table H-4. Sandia Environmental Incident Form (Concluded)

Part II (Items 8 through 14 )

13. Proposed long-term corrective action, including schedule, estimated cost and organization funding the actions.

14. This Environmental Incident Form was completed by (Supervisor or above):

$\overline{\text { Name (Printed) }} \overline{\text { Org. }} \overline{\text { Ext. }} \overline{\text { Signature }} \overline{\text { Date }}$

The proposed Short-Term Corrective Action(s) are accepted rejected

The proposed Long-Term Corrective Action(s) are accepted rejected

$\overline{\text { Name }} \frac{3220}{\text { Org. }} \overline{\text { Signature }} \overline{\text { Date }}$

Performance of Short-Term Corrective Action verified by (name, printed, and signed)

Org.

Date

Attachments included yes

no

If yes, how many pages

3220 use: Is this a reportable release? yes

Initials of Person Making Disposition

Release reported by:

Name

Org.

$\overline{\text { Date reported }}$

Copy to:

3210 W. D. Burnett

3220 G. J. Smith

3220 File

3220 Barry M. Schwartz (QA Coordinator)

3223 J. M. Phelan (for Environmental Restoration File) 


\section{APPENDIX I \\ LIST OF NEPA DOCUMENTATION}

I $-1 / 2$ 
Table I-1. List of NEPA Documentation

1989 ADMs and Approval Status

Title

Additional Trupact-II

Pool Fire Tests

Closure of The Chemical

Waste Landfill

Weapons Training Center

Classroom and Laboratory

Renovation

*Open Pool fire Tests on

the On-Site Container

Secure Test Facility

for Control Systems

Star Facility Capacitor

Bank Room and Security

Fence

Horizontal Actuator Test $\mathrm{CQ}-3$

*Wood Crib Fire Test of the W82 Recovery System

Acoustic Test Facility

Radiography Addition to

Building 894

**Explosive Components

Facility

*Wood Crib Fire Tests of Explosive Components for Allied Signal

*Open Pool Tests of an SST Trailer Wall Section Revised
Memo to DOE

$11 / 30 / 88$

$4 / 21 / 89$

$1 / 12 / 89$

$5 / 12 / 89$

$1 / 18 / 89$

$8 / 11 / 89$

$3 / 27 / 89$

$5 / 01 / 89$

$3 / 27 / 89$

$5 / 12 / 89$

$3 / 27 / 89$

$5 / 12 / 89$

$3 / 30 / 89$

$5 / 01 / 89$

$4 / 19 / 89$

$7 / 31 / 89$

$4 / 21 / 89$

$11 / 03 / 89$

$4 / 21 / 89$

$5 / 09 / 89$

$8 / 07 / 89$

$5 / 18 / 89$

$6 / 16 / 89$

$6 / 30 / 89$

$8 / 07 / 89$

$1 / 04 / 89$ 
Table I-1. List of NEPA Documentation (Concluded)

1989 ADMs and Approval Status

Title

Memo to DOE

DOE Approval Letter

\begin{tabular}{|c|c|c|}
\hline $\begin{array}{l}* * \text { The Integrated Materials } \\
\text { Research Laboratory }\end{array}$ & $7 / 21 / 88$ & $10 / 18 / 89$ \\
\hline $\begin{array}{l}\text { The Water Jet Demonstration } \\
\text { at the Robotics Vehicle Range }\end{array}$ & $9 / 20 / 89$ & $12 / 06 / 89$ \\
\hline $\begin{array}{l}* * * \text { Radioactive and Mixed } \\
\text { Waste Facility }\end{array}$ & $9 / 15 / 89$ & \\
\hline $\begin{array}{l}\text { * The Series of Pool Fire } \\
\text { Tests of the "Pat-3" PNC } \\
\text { Common Package Assembly }\end{array}$ & $10 / 29 / 89$ & $12 / 06 / 89$ \\
\hline $\begin{array}{l}{ }^{*} \text { Liquid Fuel Test } \\
\text { Facilities at Test Site } \\
9920\end{array}$ & $10 / 05 / 89$ & \\
\hline Facility Command Center & $1 C / 27 / 90$ & \\
\hline $\begin{array}{l}\text { *Performance of Four } \\
\text { Cable Fire Tests }\end{array}$ & $11 / 16 / 89$ & \\
\hline $\begin{array}{l}{ }^{*} \text { Rocket Motor Static } \\
\text { Firing Test }\end{array}$ & $11 / 29 / 89$ & \\
\hline $\begin{array}{l}\text { Solar Detoxification of } \\
\text { Groundwater Experiments }\end{array}$ & $11 / 29 / 89$ & \\
\hline B61-10 Shock Test & $12 / 13 / 89$ & \\
\hline $\begin{array}{l}\text { *Thermal Treatment Facility } \\
\text { at Building } 6715 \text { Area III }\end{array}$ & $12 / 15 / 89$ & \\
\hline $\begin{array}{l}* 12 / 89 \text { Liquid Fuel Test } \\
\text { Facilities at Test Site } \\
9920\end{array}$ & $12 / 19 / 89$ & \\
\hline $\begin{array}{l}* \text { Open Burning permit require } \\
* * \text { Decision made to write EA. } \\
*^{* * *} \text { An ADM was drafted in } 2 / 89 \\
\text { requested in } 12 / 89 .\end{array}$ & sent & An EA was \\
\hline
\end{tabular}




\section{APPENDIX J}

\section{ENVIRONMENTAL COMPLIANCE ACTIVITIES AT KAUAI TEST FACILITY}




\section{J.1 Introduction}

Sandia National Laboratories (SNL) operates a rocket preparation and launch facility called the Kauai Test Facility (KTF) at the Navy's Pacific Missile Range Facility (PMRF) - Barking Sands, for the Department of Energy (DOE). The KTF is used to launch rockets in support of DOE missions, as well as other U.S. Government projects (SNL, 1986).

\section{Facilities and operations}

SNL's KTF is located on the north part (near Nohili Point) of the Navy's PMRF, which sits on the west side of the island of Kauai, HI (Figure J-1). The majority of the facilities at the KTF were constructed in the early 1960 s to support the National Readiness program. The most recent construction activity, completed in 1989, added five buildings and a new launch pad to support future DOE and Strategic Defense Initiative (SDI) launches.

KTF has been, and is being, used for testing rocket systems with science and technology payloads, advanced development of maneuvering re-entry vehicles, scientific studies of atmospheric and exoatmospheric phenomena and SDI programs. No nuclear devices have ever been launched from KTF.

The KTF launcher field was originally designed to accommodate 40 launch pads, but only 15 pads were constructed. of these, 12 are presently inactive with the launchers removed. Since the original plan, two additional launch pads have been constructed, Pad 41 at Kokole Point and Pad 42, the STARS launch pad. The launcher field site has a number of permanent facilities used to support the rocket operations.

The administrative area of the KTF is located in a fenced compound near the North Nohili access road from PMRF. Within the fenced compound, a number of trailers and vans are interconnected with a network of concrete docks and covered walkways. The majority of these temporary facilities are used during operational periods to support field staff at the KTF. In the nonoperational periods, they are in standby condition with only dehumidifiers in operation. In addition, there are a small number of permanent buildings, most of which are in use year-round to support and maintain the KTF facilities (Helgesen, 1990). 


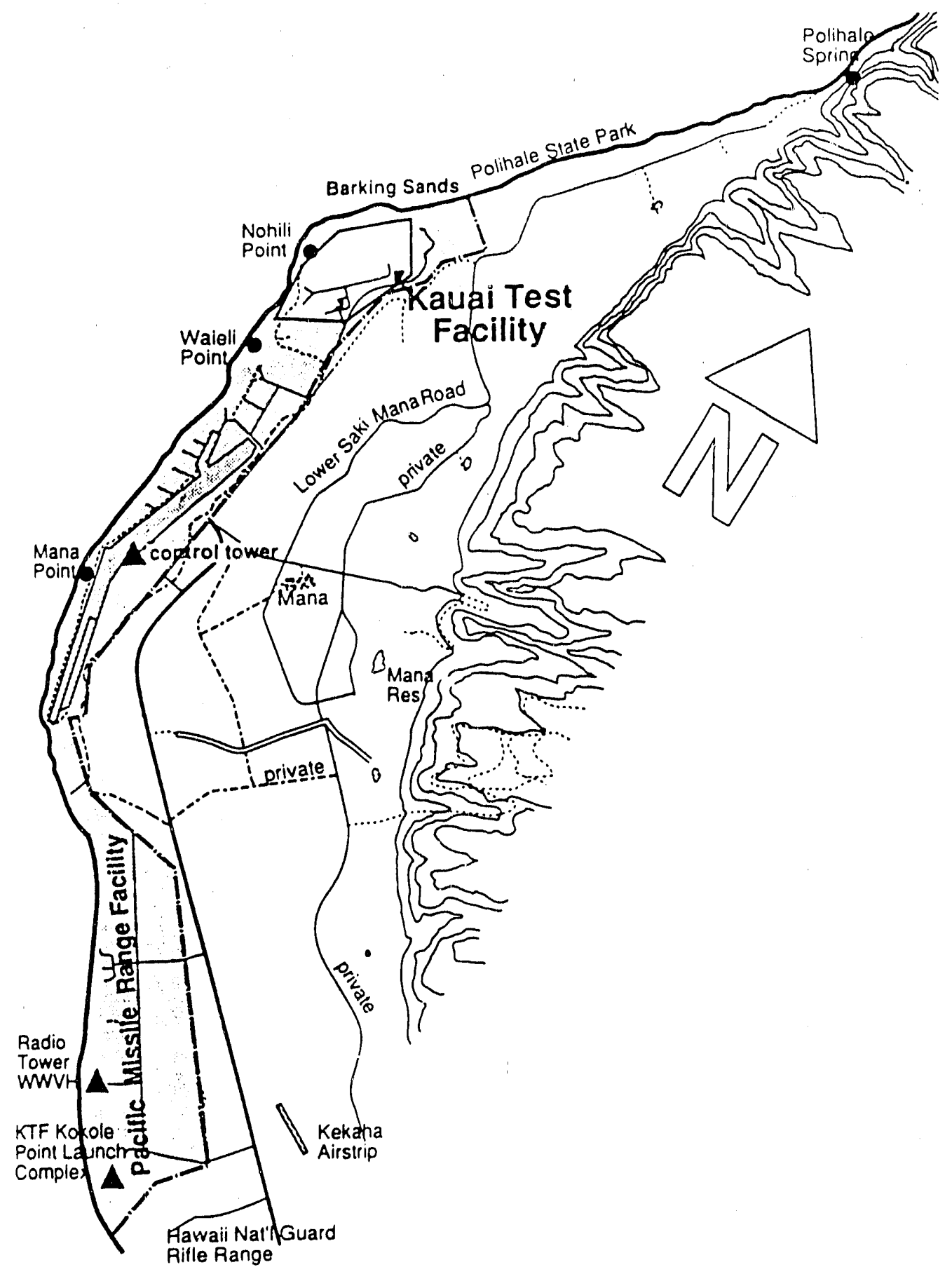

Figure J-1. Map of the Pacific Missile Range Facility (PMRF) and the adjacent area. The Kauai Test Facility (KTF) is to the north, near Nohili Point. 


\section{Geology and Hydrology}

The KTF and PMRF are located on the seaward margin of the broad Mana coastal plain of Kauai. The Mana coastal plain is composed of alluvium washed from uplands, calcareous and clayey lagoon deposits, sand dunes, and beach rock. The poorly consolidated deposits of the present plain were formed in a shallow lagoon behind an ancient beach ridge. The large wetland was largely filled in and planted with sugarcane by 1936 , leaving only some small areas of wetland near Mana, about 10,000 ft from the KTF.

The KTF lies in the rain shadow of Mounts Kawaikini and Waialeale. The annual rainfall is about $20 \mathrm{in}$. per year. There is no integrated surface drainage on the site. The sand is so permeable and its moisture-holding capacity so low that no drainage pattern has become established on the surface. Rain simply sinks into the sand and disappears.

The Mana Plain is composed of a wedge of terrestrial and marine sediments overlying a volcanic basement. The basement rock outcrops at the inland edge of the Plain; its steep slope is a cliff formed during a former highstand of the sea. The volcanic basement plunges below the Plain at a dip of about 5 degrees until at the coast it is about $400 \mathrm{ft}$ deep.

The seaward edge of the Plain is covered by fossil sand dunes formed when the sea was lower than it is now. The PMRF is located almost entirely on these dunes, which now are no higher than $10 \mathrm{ft}$ or so except just to the north of the KTF, where they are up to $100 \mathrm{ft} \mathrm{high}$.

The three geological formations (bedrock, alluvium, and dunes) constitute hydraulically connected aquifers. The basement volcanics are highly permeable, containing brackish water floating on sea water. The overlying sediments act as a caprock because of their low permeability; they are saturated but are not exploitable as an aquifer because of their unfavorable hydraulic characteristics.

The dune sand aquifer, on which the PMRF lies, has a moderate hydraulic conductivity and a reasonable porosity. It consists of a lens of brackish groundwater floating on sea water, and is recharged by storm rainfall and by seepage from the underlying sediments. The only record of an attempt to exploit this groundwater is of a well drilled for the Navy in 1974,4 to 5 miles south of the KTF. It was dug to a total depth of $42 \mathrm{ft}$, encountering only fine sand and coral gravel. Tested at $300 \mathrm{gpm}$, it initially yielded water having $2,800 \mathrm{mg} / 1$ chloride, which is too brackish for flants. This well is not used (SNL, 1986).

\section{Biology and Population}

The principal vegetation found on Kauai consists of two introduced shrub species: Kiawe, a mesquite; and koa-haole, a wild tamarind. Portions of the island are covered with nearly impenetrable thickets of kiawe and koahaole (SNL, Albuquerque, 1986). The land on which the present KTF 
facilities lie has been cleared from brush and has a thin cover of grasses and herbs.

The sandy soil appears barren and incapable of supporting agriculture unless improved by mixing with soil, fertilizing extensively, and irrigating it.

No mammals or signs of mammals were encountered during a 1986 field sulvey (SNL, Albuquerque, 1986). However, it is quite likely that there may be populations of mice and rats. The endangered Hawalian Hoary Bat (Lasiurus cinereus semotus) may also be found, at least occasionally, as there are breeding populations elsewhere on Kauai.

Twenty-two species of birds were found on the range, plus three more just outside the range (SNL, Albuquerque, 1986). There are also several species of waterfowl that may be present on the range during some portion of the year, even though they were not seen during the 1986 survey. These 25 include five species native to Hawail.

The nearest off-base community is the village of Mara, estimated population $30,10,000 \mathrm{ft}$ to the south. The population at KTF fluctuates between 10 and 70, depending on mission schedules. The majority of approximately 200 military personnel are stationed at the Pacific Missile Range Facility.

\section{Meteorology}

The KTF lies in the rain shadow of Mounts Kawaikini and Waialeale. This part of the island is sheltered from the predominant northeast tradewinds and as such is one of the driest sections of Kauai. Average rainfall is just over $20 \mathrm{in./yr}$. Most of this falls between October and April. Under normal conditions, winds are generally light and variable; abnormal conditions can result in gusty winds in excess of 30 knots from southerly, westerly, or northerly directions. Mean monthly temperature is $70^{\circ} \mathrm{F}$, with maximums in the low $90 \mathrm{~s}$ and minimums in the mid $50 \mathrm{~s}$.

\section{J.2 Significant Environmental Compliance Activities}

\section{NEPA Compliance}

There were no Action Description Memorandums (ADMs) prepared for KTF during 1989. The draft Environmental Assessment (EA) for KTF was prepared in 1989. It is being reviewed by SNL, Albuquerque and DOE, Albuquerque Operations office (DOE/AL). Once the EA is finalized, a draft FONSI, if appropriate, will be prepared for approval by the DOE.

\section{Environmental Permits}




\section{$\underline{\text { Air }}$}

There are no PSD or NESHAP sources for the facility and no air permits are held by e ther the DOE for KTF or the Department of Defense (DOD) for the Pacific Missile Range. However, the two electrical generators at KTF are permitted by the State of Hawail for air emissions.

\section{Water}

Wastewater is treated onsite by a wastewater treatment system, consisting of septic tanks and leach fields into brackish water. The limited quantities of sewage released from KTF do not impact any protected water. Periodic drainage of septic tanks is accomplished by State of Hawaii licensed contractors who dispose of wastes according to state regulations. The facility currently holds two permits for the rwo septic tanks onsite.

\section{Solid Waste}

The PMRF holds a RCRA Interim Status Permit for treatment and storage of hazardous waste. $\mathrm{KTF}$, as a tenant on PMRF, is a small quantity hazardous waste generator. These small quantities of hazardous chemical wastes are disposed through the PMRF tenant agreement. The PMRF also transports nonhazardous solid waste to the county landfill.

One or two rocket explosions near a launch pad have scattered debris in close proximity to the pads. All debris was collected and disposed through the PMRF program.

\section{Release Reporting}

A11 of the 1989 releases from KTF are air emissions of lead (Pb) as results of Terrier Malmute Rocket or NIKE Rocket System tests. Reportable Quantity (RQ) for lead is one pound. The release reporting was initially made by KTF staff to Environmental Programs Department (3220) at SNL, Albuquerque. The final reporting was then made by SNL, Albuquerque to National Response Center (NRC) by telephone reporting and in written reports. Table J-1 lists the Summary of 1989 Release Reporting from KTF.

Table J-1. Summary of 1989 RQ Release Reporting

\begin{tabular}{|c|c|c|c|c|c|c|c|}
\hline Date & Location & Material & Quantity & $\mathrm{RQ}$ & $\begin{array}{l}\text { Release } \\
\text { to }\end{array}$ & $\begin{array}{l}\text { NRC } \\
\#\end{array}$ & $\begin{array}{l}\text { Report } \\
\text { Date }\end{array}$ \\
\hline $9 / 05 / 89$ & $\mathrm{KTF}$ & Lead & $20.4 \mathrm{lb}$ & $11 \mathrm{~b}$ & Air & 15689 & $9 / 05 / 89$ \\
\hline $9 / 11 / 89$ & $\mathrm{KTF}$ & Lead & $20.41 \mathrm{~b}$ & $11 b$ & Air & 16195 & $9 / 12 / 89$ \\
\hline $9 / 12 / 89$ & KTF & Lead & $3.71 \mathrm{~b}$ & $11 \mathrm{~b}$ & Air & 16200 & $9 / 12 / 89$ \\
\hline
\end{tabular}




\section{J.3 Environmental Restoration and Monitoring Prograin}

There is no routine environmental monitoring program for KTF due to the nature of the operations occurring at the site. However, special sampling and monitoring are done on a case-by-case basis. The Environmental Restoration (ER) program has performed a Preliminary Assessment (PA) of the KIF to identify sites where past spills or releases might have caused environmental degradation. Two sites were identified: Drum Rock Area and Photo Lab Discharges.

Soil samples from two launch pads and tape samples from a transportainer were taken in October 1989. The soil samples from two launchers (12 and 14) were analyzed for lead contamination against the background soil. At launcher $12,50 \mathrm{ppn}$ were detected in each of the two samples taken. At launcher 14, $86 \mathrm{ppm}$ and $415 \mathrm{ppm}$ were detected respectively in two samples. No lead was detected in both background samples at a detection level of 1 ppm. The potential significance of these lead levels will be assessed in the future under the ER program.

One of the tape samples taken was found positive for chrysotile asbestos by Division 3211. A recommendation was made to treat the putty as asbestoscontaining and dispose of it along with the tape in accordance with asbestos regulations.

\section{J.4 Other Compliance Activities}

Spill Prevention and Control Countermeasure (SPCC)

SNL at KTF is part of the PMRF Spill Prevention and Control Countermeasure Plan (SPCC) that provides support in the event of a diesel fuel spill from the $10,000 \mathrm{gal}$. above ground fuel tank just outside the compound.

Underground Storage Tanks (USTs)

Underground gasoline tanks in the compound are being replaced with one double wall fiberglass tank, which along with the installation, complies with the most recent Federal and State regulations.

Diesel fuel, gasoline, and oils such as mechanical oils and hydraulic fluids are stored and used in large quantities at the KTF. The underground fuel tank will be monitored for leakage as required by the Resource Conservation and Recovery Act (RCRA).

Toxic Substances and Control Act (TSCA)

Under the Toxic Substances Control Act (TSCA), oil containing electrical and mechanical equipment and hydraulic fluid containing systems must be assumed to be Polychlorinated Biphenyl (PCB) containing systems unless sampling and analysis show otherwise. The transformers on the KTF site have been tested and shown to be free of PCBs. 


\section{REFERENCES}

Helgesen, R, F., 1990. "Safety Assessment for the Kauai Test Facility at Barking Sands, Kauai," SAND89-2548, Sandia National Laboraties, New Mexico, April 1990.

Sandia National Laboratories, 1986. "Environmental Report, Proposed IRBS Facilities, Kauai Test Facility," prepared by Sandia National Laboratories, Albuquerque, NM, for the DOE, August 1986. 

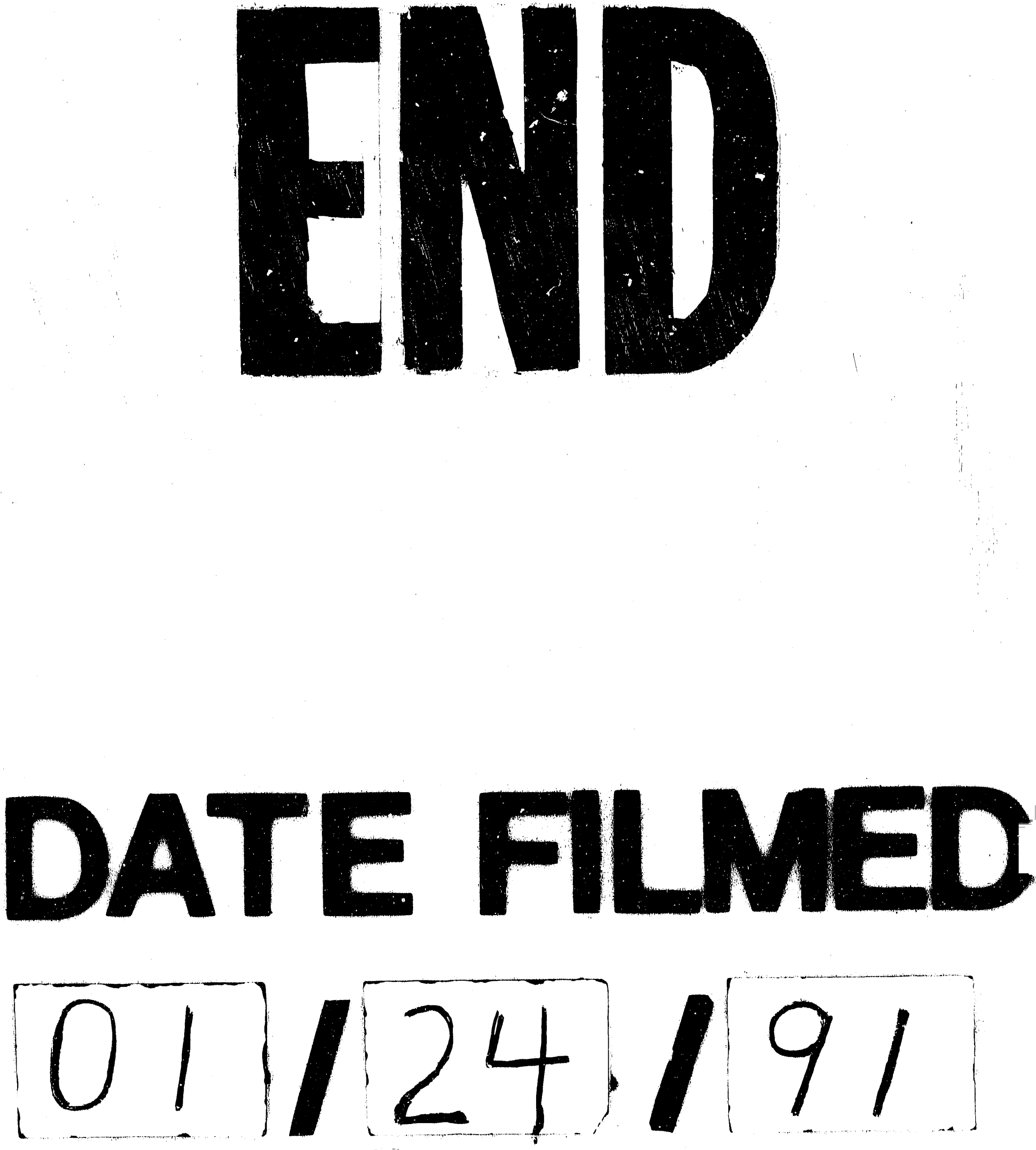
